New Multicultural Identities in Europe

Religion and Ethnicity in Secular Societies 


\section{CURRENT ISSUES IN ISLAM}

\section{Editorial board}

Baderin, Mashood, SOAS, University of London

Fadil, Nadia, KU Leuven

Goddeeris, Idesbald, $K U$ Leuven

Hashemi, Nader, University of Denver

Leman, Johan, GCIS, emeritus, KU Leuven

Nicaise, Ides, $K U$ Leuven

Pang, Chinglin, University of Antwerp, and KU Leuven

Platti, Emilio, emeritus, KU Leuven

Schallenbergh, Gino, KULeuven

Tayob, Abdulkader, University of Cape Town

Stallaert, Christiane, University of Antwerp, and KU Leuven

Toğuşlu, Erkan, GCIS, KU Leuven

Zemni, Sami, Universiteit Gent 


\section{New Multicultural Identities in Europe}

Religion and Ethnicity in Secular Societies

\section{Edited by}

Erkan Toğuşlu, Johan Leman \& İsmail Mesut Sezgin 
(C) 2014 by Leuven University Press / Presses Universitaires de Louvain / Universitaire Pers Leuven Minderbroedersstraat 4, B-3000 Leuven (Belgium)

All rights reserved. Except in those cases expressly determined by law, no part of this publication may be multiplied, saved in an automated datafile or made public in any way whatsoever without the express prior written consent of the publishers.

ISBN 9789058679819

$\mathrm{D} / 2014 / \mathrm{I} 869$ / I

NUR: 74I/717

Layout: CO2 Premedia

Cover design: Paul Verrept

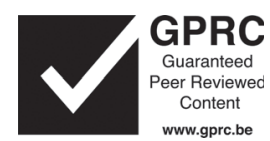




\section{Table of Contents}

\section{Introduction}

I. The Manifestation of Identities in a Plural Post-Secular Europe Johan Leman, Erkan Toğuşlu and İsmail Mesut Sezgin

\section{Part I: Post-Migrant Interactions/Identifications}

2. New and Old Identity Patterns of Religious Young Muslims in Germany

Cüneyd Dinç

3. Connecting Home and School: on the Second generation Muslim Children's Agency in Belgian Schools

Goedroen Juchtmans

4. Immigrant Identity, Social Adaptation and Post-Secular Society in Europe

Marcel Meciar

5. Manufacturing Self-Respect: Stigma, Pride and Cultural Juggling among Dalit Youth in Spain

Kathryn Lum

6. A Case of Euro-Muslimness in Poland? The Polish Tartars Katarzyna Warminska 


\section{Part II. Non-Migrant, Anti-Islam Interactions/Identifications}

7. 'Anti-Islamisation of Europe' Activism or the Phenomenon of an Allegedly 'Non-Racist' Islamophobia

Vincent Legrand

8. Discourses on Religion and Identity in Norway. Right-Wing Radicalism and Anti-Immigration Parties

Frédérique Harry

9. Competing Forms of Identity and the Concept of Sovereignty in Europe

Murat Sevencan

Io. Democratic Theory and the Autonomy of Non-Christian Religious Courts in the UK

Ephraim Nimni

II. Islamophobia and the Rise of Europe's Multiculturalism

Chris Allen

\section{Conclusion}

12. Ethnic-Religious Intersections and New Multiculturalism

Johan Leman, Erkan Toğusslu and İsmail Mesut Sezgin 
Introduction 



\title{
CHAPTER I \\ The Manifestation of Identities in \\ a Plural Post-Secular Europe
}

\author{
Johan Leman, Erkan Toğuşlu and İsmail Mesut Sezgin
}

\section{Global - local identifications}

In 1969 the Norwegian anthropologist Fredrik Barth published his Ethnic Groups and Boundaries. In his words, it is not cultural stuff that creates social borders, but flexible social borders which create culture. He was not the only one, though, to ask for attention to be drawn to the constructive chemistry which takes place in ethnic boundary creation. Leach (1954), prior to the time of Barth, had already emphasized the constructive and flexible character of social boundaries. And also Moerman (1965) had taken a similar approach, finding the earlier approach adopted by Weber (1922) to be insufficient, and instead contending that ethnicity is a useful concept.

However, people who studied in the 1960 s and who completed their first fieldwork undertakings in the 1970s will remember how the range of their research field changed dramatically from the 1990 s on. The context started changing very fundamentally. Globalization created a new horizon. By the beginning of the 1990s, one of the first interesting theorists of the global, Roland Robertson (1992), had reacted to McLuhan's homogenizing 'global village' concept (1962) by opposing the idea that globalization would lead to homogenization. In his words, it was not homogenization that would be the outcome, but glocalization. He predicted a search for fundamental truths (religious and nationalistic) as well as what he called a particularization of the universal. In this logic, globalization would not de-ethnicize religion. Of course, the global would have an impact on it, since the tools and instruments would belong to the world of the global. 
But this would lead in some cases to local enclaves of religious and national identification, stretching even as far, on more than one occasion, to religious fundamentalisms. It is about specific ethnic-religious dynamics in such a cluster of processes in today's Europe that the authors of this book will bring us some empirical information and the results of their reflections.

What Robertson did not foresee, perhaps because it was not that active at the beginning of the 1990s, is that the global, with its transnationalism and transnational social movements, would also become the site of the beginning of a lot of 'in between' trans-border median spaces (in Barth's 1994 phrasing). Barth proposed to distinguish three levels of processes that evolve by themselves: a micro (or personal) level, a macro level (of 'state policies'), and a median level, where processes "create collectivities and mobilize groups for diverse purposes by diverse means" (Barth 1994:2I). The impact of the global on the median level (where the internet has become an important factor) is very clear from the mid I990s on, not least among religious identifications. "What happens is that the inner boundaries inside the transnational faith communities are removed. This de-territorialisation, so typical of virtual communication in the Web, leads to the enlargement of existing communities which adhere to the same branch of a religion" (Leman 2009: 199). In 1974 Barth also accepted that cultural practices as such may have an impact on the way social processes develop (see also CerroniLong 2007), an idea that should be taken into consideration when studying today's ethnic-religious developments in Europe.

These developments bring us to the core of the issues that the reader will find considered in the chapters of this volume. The religions that will be treated are: Islam (in most chapters), Christianity, Judaism and Hinduism (this last as viewed through the eyes of the Indian Spanish Dalit community). Islam will be the focus, and this is not surprising since, surely from 'nine eleven' (200I) on, it has been Islam and Muslims that are at the heart of the debate on multiculturalism in Europe. The fields that have been studied are situated in Turkey, Germany, France, Spain, the United Kingdom, Poland, Norway, Sweden and Belgium, but also Europe in general.

\section{Main interests}

The book we present is concerned with looking at the extensive phenomena of identifications in Europe at the beginning of the $2 \mathrm{I}^{\text {st }}$ Century. The 
identifications will reveal themselves to be expressed in various alternative forms of religious-ethnic manifestation and they will overlap with migrants, students, religious figures, multicultural politics and lifestyles. The book is not just about identity; rather the chapters analyse the issues relating to the question of identification and the expression of identity in multiple forms in new glocal, transborder contexts. It explores the concrete experiences and positions of subjects in terms of transborderless and trans-ethnic communities, for example Polish Tartars, Belgian Turks or German Muslim Turks, .... From a political-science perspective, Brubaker's idea of 'ethnicity without groups' relevantly poses the question of changing the characteristics of ethnicity in relation to religion, symbols, nation, territory, memory, institutions, networks, categories and schemes (Brubaker 2004: 4). Such complex identifications cannot be encompassed by just race-ethnicity, gender and religion alone; the multiple cultural-situational-political elements can also produce identities which are shaped by the new circumstances of de-territorialization.

Identities are developed in relation to one's nation, religion, gender, class, language, and daily life practices. They are not fixed/static and they are constructed in many, complex ways. Identity is about similarity, difference, recognition and representation in the public area (Helicke 2002). It is constructed through the interaction between different frames, schemes, symbols and cultures. The concept of identity is over-used and has expanded so much that it has lost its specificity. For this reason, in this book the emphasis is on the manifestation of identities in a plural Europe, where some identities are becoming more visible. Through the lens of post-migrant societies, we will try to analyse the mobility of identities in some specific religious communities and groups.

It is important to note that in post-migrant societies alternative, marginal identities may also become a part of the mainstream identity. In order completely to understand this re-localization of the mainstream, we need also to look at the blurring of boundaries such as those between orthodoxy-heterodoxy, localglobal and individual-community. The use of information technology and the advancement of mass media have transformed the character of the mainstream identity. In other words, a particularization of the universal has appeared. The identities have been pluralized, fragmented and de-territorialized during the last decade. It is not clear where the boundaries exist and where they are recreated into new forms of identification. The blurred identity raises concerns about the problematic nature of boundaries and borders between various ethnic-religious groups, as well as within the same ethnic-religious communities. 
Through the findings and reflections from the various chapters, we will try to make three main points: I) the emergence of transnational and translocalglocal identities and communities is tied to the logic of globalization and the network society (Castells 1996). In these networks, the multiple loyalties and de-territorialized identities are formed during daily life practices, discourses and policies. 2) Transnational subjects (Muslims, Jews, youth, female, political activists...) have a direct influence and impact on the discussion of multiculturalism. The new multiculturalism is post-secular, more trans-migrant coloured and border widening. 3) The new communities having de-territorial identifications pose some challenges to the existing political-social models of society which re-activate an indigenous anti-migrant and anti-religious formulation of reaction to the new multiculturalism. The new communities brought into play the old-new hostilities and conflicts in the public sphere, especially in relation to religious ones.

Some questions will arise on more than one occasion and will be answered in a variety of ways. What is the impact of social and economic transitions on the globalization processes, and on ethnic and religious identifications? What are the roles of transnational social movements in these macro-processes? What are the challenges for the classic ethno-religious identity debate? In our conclusion (chapter I2), which will also be our final reflection, we will pick up the idea that the ethnic-religious identifications are changing due to trans-border and glocal intersections, relating more broadly to the global.

The authors - sociologists, anthropologists, political scientists and other social scientists - are from a variety of different countries. This international and interdisciplinary background has nourished their reflections, as the reader can plainly observe from the quality of the presentations. It also puts the editors and the authors for some challenges: what does an author in a precise discipline mean by words such as ethnic identification; globalization, glocality and transnationalism; multiculturalism and being a post-migrant; the secular and post-secularism? We will define them shortly before continuing our introduction.

\section{Ethnic identification}

For our definition of ethnic identification we opt for an anthropological approach. Ethnic identification will then always give some weight to a "subjective, symbolic or emblematic use... of any aspect of culture, in order to differentiate... from 
other groups" (Brass 1991: 19). It will do so on the basis of "a feeling of continuity with the past, a feeling that is maintained as an essential part of one's selfdefinition" (De Vos 1975: 17). Doing this, it will provide "reservoirs for renewing humane values" (Fischer 1986: 176). It is not "the cultural stuff that it encloses" that fundamentally determines the borders, but it is "the ethnic boundary that defines the group" (Barth 1969: 15); this boundary is primarily social in nature. This brings us once again to Leach (1954) and Barth (1969). Ethnicity is selfascribed and flexible and is not imposed by others. Ethnicity, as a kind of selfidentification, concerns the "categories of ascription and identification by the actors themselves" (Brettell 2007:I0). Boundaries are places of social interactions "that mark difference and shape identity" (Brettell 2007: IO-II). Very often ethnic processes use kinship terminology as a kind of glue in the group. While ethnicity may have become marketable (Comaroff and Comaroff 2009), it has also become absorbed in religious median structures, namely in faith communities. Research shows that such religious communities very often have their origins and ethnic connotations in specific countries and shift into religious, de-ethnicized movements once they leave their countries of origin (due to migrations) and become integrated in a more global context. The findings in this book will show that this has become quite common in the European post-migrant landscape and in the West in general.

What is striking is the immigrants' normal developing momentum, the rate at which they settle themselves, which is applied with respect to fields as diverse as the labour market, housing culture and existing regulations, and to the already existing cultural context in the country of destination. Schools ensure that their children and grandchildren will hasten this process further. An emotional attachment to the region of origin over several generations is maintained and reinforced in some cases, especially through their private culture, but also by religious structures. In other situations they create something new. Commitment to the country of origin as well as the creation of something new brings about the resulting loyalties, ethnic, supra-ethnic, meta-ethnic (Leman 1999).

But even indigenous people, for whom 'home' - where their parents, grandparents and earlier generations have lived - is not a neutral space but full of affections, do not remain inactive. We may expect that some among them will use features that allow them to distinguish themselves from migrants and their latter generations. They can rely on a long historiography that they, not without some arbitrariness, claim to occupy. For their ethnic compositions, the antimigrants will go in search of historical matrices and historical emblems in their 
'own home' and of 'cultural stuff' in the essentialized cultural past of the (mostly Islamic) migrants to convince themselves that multicultural cohabitation is impossible.

\section{Globalization, glocality and transnationalism}

We are aware that the notions of 'globalization', 'glocality' and 'transnationalism' each in itself may cover a lot of slightly different processes. They require more precision when applied to very concrete situations. With the definitions that we will propose we want adequately to cover the clusters of realities which the authors will refer to in their chapters, though giving each notion a more precise content when needed.

Globalization in our text is "what happens when the movement of people, goods, or ideas among countries and regions accelerates" (Coatsworth 2004). The "global society [is] a network society" (Castells 1996), with a "global interconnectedness, suggesting a world full of movement", and in this sense it becomes a complex mixture of processes which often also produce conflicts, disjunctures and new forms of inequality (Carling 2006; Giddens 1999: 15-18). There are economic factors at work, but at least so important are the social "contacts and linkages" (Xavier Inda and Rosaldo 200I:2).

As some social scientists tell us about the difficulty of naming and describing the social locations of migrants, we prefer to use transnational and glocality as a response to globalization and mass media communication. When the global is the "macroscopic aspect of contemporary life," glocalization becomes its "conjunction with the local, in the sense of the microscopic side of life" (Robertson 1993: 173). But at the same time, "many immigrants today build social fields that cross geographic, cultural, and political borders" and "we define 'transnationalism' as the processes by which immigrants forge and sustain multi-stranded social relations that link together their societies of origin and settlement" (Basch, Glick Schiller and Blanc Szanton 1994: 6). Researchers have studied transnational identity formation in economic, social, political and religious areas (see Basch, Glick Schiller and Szanton Blanc 1994; Ebaugh and Chafetz 2002; Faist 2000; Fraser 2007; Vertovec 2003). 


\section{Multiculturalism and being a post-migrant}

We subscribe to Baumann's point of view that "multiculturalism is not a patchwork of five or ten fixed cultural identities, but an elastic web of crosscutting and always mutually situational, identifications" (Baumann 1999: II 8). But where migrants have a myth of return ideology this is no longer the case with most of the second generation, or with almost all of the third generation 'migrants' who are really no longer migrants (see, among many other authors, Ali and Holder 2006). Nevertheless they continue for some generations to develop a relationship with the country of provenance of the first generation that remains different from the feelings of the classic tourist (Wagner 2008, 20II), and in the country where they are born they most of the time have also to struggle to be recognized by others no longer as migrants but as full citizens on an equal basis. That is why we call them 'post-migrants'. In the case of the Polish Tartars (chapter 6), we will even speak of a post-'post-migrant' situation, since the relationship with a home country of provenance does not exist at all and finds support only in the fact that they know that other Tartars just like them are living as minorities in neighbouring countries.

\section{Secularization and post-secularism}

"The shift to secularity ... consists, among other things, of a move from a society where belief in God is unchallenged and indeed, unproblematic, to one in which it is understood to be one option among others, and frequently not the easiest to embrace" (Taylor 2007: 3). Charles Taylor refers to mainline secularization theory as a point of view that "sees religion shrinking further and further" (2007: 766). Rodney Stark sees five arguments and/or characteristics among social scientists who support secularization theories: (I) modernization as a "causal engine dragging gods into retirement", (2) a "primary concern with individual piety, especially belief", (3) "it is science that has the most deadly implications for religion", (4) "once achieved (secularization) is irreversible", $(5)$ it is a global process, and it concerns not only Christianity (Stark 1999: 252-253). Stark however remarks that secularization theory "never was consistent with empirical reality" (Stark 1999: 249). Taylor also foresees "another future, based on another supposition" (2007: 768). He expects a double move: "[s] ome will want to move further 'inward', towards a more immanentist position ... and some will find the 
present equilibrium confining, even stifling, and will want to move outward" (2007: 770).

Habermas reflects on this second move. Looking at European continental countries, he describes modern societies as 'post-secular', referring to a change in public-private consciousness (Habermas 2008). In his view, these changes come from three phenomena: the global conflicts that are presented as religious strife, the gaining of religious influence in national-international politics and the movement of people, specifically the immigration of people of faith. ${ }^{1}$ These three phenomena transform the public secular consciousness which delegates religious identity to the private sphere. All European societies have faced this change of consciousness in the last two decades and they simultaneously remain diverse and plural societies; however, there is a slight change in the fact that we have more religiously pluralistic societies. In this plurality, the flow of people who keep their religious affiliations, beliefs and identifications creates religious chains of memory (Hervieu-Léger 1996). The implication of newcomers' religion, beliefs and their visibility is, according to Habermas, challenging the modus vivendi in continental Europe that exists between citizenship and cultural-particular difference which ought to take into consideration the observance of the plural identities in Europe. This modus vivendi has been drastically questioned, as we see in debates on multiculturalism in Europe, where secularism was highly determined during the $20^{\text {th }}$ century by French 'laïcité', much more than has been the case in the Anglo-Saxon world.

This recasting of religious change in continental Europe requires more studies in the field to show how traditional-modern-transnational religious loyalties and identifications are resurfacing. This indeed has an impact on secular continental Europe, referred to now as a post-secular. It is an important objective of this book to present empirical findings and reflections that may nourish the debate.

\section{Redefined boundaries in post-migrant societies}

The flow of ideas and migrant people at the end of the $20^{\text {th }}$ century and the beginning of the new millennium does not attenuate the role of existing borders. In his seminal work, Barth, whom we have already discussed, tried to show that the borders distinguish between two distinct things through ethnic-cultural markers such as dress, food, and language (Barth 1969: 14). Boundaries mark the limits of group awareness. The dispersal of people coming from the same 
group (ethnic, religious or cultural) in such diversity invites us to examine in what way boundaries are fabricated and reformed. Thus, the locally constituted ethnic identity, after spreading out into new geographies, is dis-corporated from the existing/original identity. Immigration and mobility are giving rise to the possibility that individuals will exchange one identity for another, even though the boundary between two groups is maintained in terms of cultural difference. Crossing borders, real or imaginary, is part of a dis-corporation and displacement of the identity issue. The borders may be rigid or fluid, but they are always changing, transforming and challenging the existence of fixed identities. The variety of ethnic-religious communities poses some challenges, such as adaptation to new cultures, loyalty to the practices of parents.

A consciousness marked by dual or multiple loyalties and identifications may arise. The coexistence (specific or not) of several identities of the migrant communities maintains a new hybrid identity. As Clifford (1994) points out, these immigrant communities strengthen solidarity and connection among themselves. This connection makes a difference.

The intersection of religion, identity and ethnicity is a complex phenomenon and raises very important questions in public debate. There is no accepted clear definition of the relationship between ethnicity and religion. In recent times, scholars have begun to pay more attention to the intersection of ethnicity and religion, particularly as a consequence of mass media, the use of the Internet, the use of communication, mass immigration and the flow of people. Throughout this book, the reader will observe the different ways of using symbols, narratives, networks and schemes which emerged as clusters of ethnic-religious practices and discourses. In post-migrant societies a growing number of people define themselves in terms of these multiple symbols and schemes of identity (Caglar 1997: 169). These clusters of practices and discourses define ethnicity in terms of recognition. "What cognitive perspectives suggest in short, is that race, ethnicity, and nation are not entities in the world but ways of seeing the world" (Brubaker 2004: 8I).

The ambiguity concerning a re-definition of identity through new discourses and practices becomes more puzzling when seen through the lens of trans-border identification and transnationalism. In considering these multiplicities, three chapters (Dinç, Lum and Nimni) set out the challenges to the endurance of religious-ethnic identities. The relational construction of other social dimensions such as lifestyles, gender, festivities (Lum, Juchtmans) forces ethnic-religious identity into ongoing change and transformation. In ourview it was very interesting 
to insert a chapter on a non-Muslim community (Lum), so that the reader should be very aware that most of what is written about Muslim communities also remains valid for other, non-Muslim minorities of non-Christian provenance in Europe. The new communities, including the virtual ones, with particular reference to the religious and ethnic settlement in the new lands, are created thanks to globalization and the Internet (Leman 2009). They are between states and borders, neither here nor there, but they are present and active in both.

\section{Glocal and transnational ethnic-religious identities}

After Vertovec, but also after other authors, the concepts of transnationality and glocality gripped social scientists' attention for a while. This means indeed that it can be a part of the theoretical base to approach the changing characters of identities and structures, and of the everyday networks and practices emerging in daily life (Vertovec 2002). In these new networks, we leave migration behind to depict the problem of in-between situations in terms of transborder and postsecular societies and communities. It should be noted that the appearance of transnational ethnic-religious identity is coming to terms with questions and problematics around mobility, multicultural hybridity, hyphenation (namely double ethnic identification) (Caglar 1997), and other creative practices which are the keywords to explaining how being in a state of glocality throws objects, identities and ideas into flux (Mercer 2008). In post-migrant societies, this fluidity is rehearsed, re-articulated and re-shaped along with ethnic-religious creativity.

A closer look at the study of this problematic religious identity in translocal and transborder cases shows some particular challenges in describing and formulating the new boundaries of identification. Firstly, we have the non-fixed elements of religious life and the dynamic shared meanings, symbols and attachments used in different ways by religious people and religion itself in non-bounded and framed situations. Many features of religious life are implicitly lived and hard to define as public expressions (Levitt 200I). "They are deeply felt but often difficult to express," says Levitt to describe this first challenge of the transnational religious identity. Some public expressions and visible patterns of religion in public space do not explain religious feeling as an identity or an ideology. Thus, framing a religious identity in a given space and time is (a thin) problematic, not just about an expression (Hetherington 1998). 
Percentage and estimated number of all immigrants in the European Union by religious group*

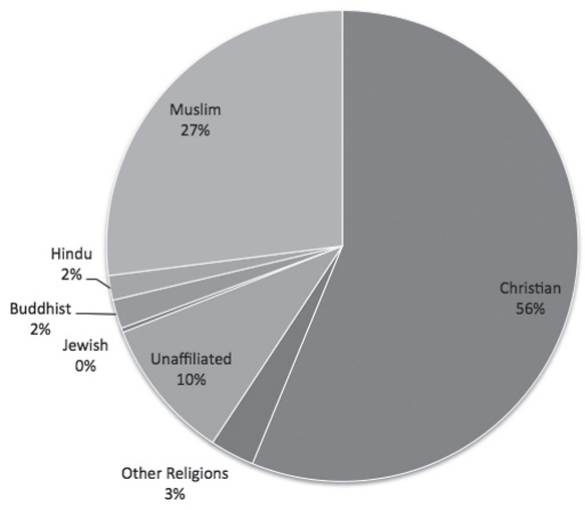

Percentage and estimated number of immigrants in the European Union (excluding migration within the European Union) by religious group*

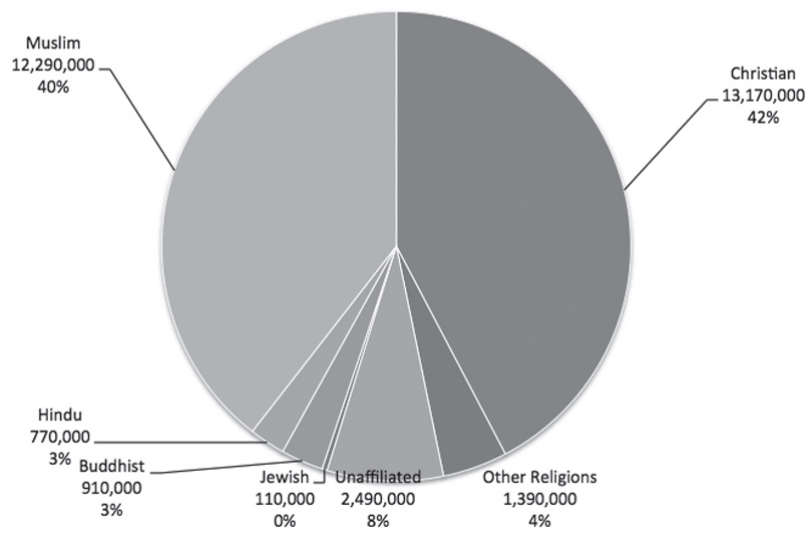

*Population estimates are rounded to ten thousands. Percentages are calculated from unrounded numbers and may not add to 100 due to rounding.

Figure I - Religious Composition of Immigrants in the European Union

The second challenge comes from the mobility of people and issues relating to migration. It is manifested as a question of maintaining the adaptation and of the sustainability of this form of identity in new circumstances. The process of adaptation is crucial and a considerable research question in transnational religious identity (Vertovec 2002). Here attention to a religious change and transformation has gained significance among migrant Muslim communities in Europe (Cesari 
2007). Host-home country relations affect and change the religious identity of religious communities (Helicke 2002). Migration and mobility generate alternative places and patterns of identification, so that religious identities and symbols are reshaped across national borders. Transnational religious identity however is not post-national and it does not make us deny the nation-state. But the host-home country incorporations give more impetus to this new spectrum of religious identifications. The identification issue is reinforced by the search for an authentic experience among young migrants in their new lands in Europe.

\section{Post-secular Europe, immigration and religious identity}

The new arrivals recast religious identity and secular space in Europe. Immigration still continues, and as reports show, in the future for example people who identify with the Christian tradition are likely to continue to move and arrive in Europe in larger numbers. This means that the traditional religious identity may reappear. It is also useful here to consider the ways in which religious identity in Europe has been transformed due to the arrival of immigrants since the 1960s. The new immigrants and their descendants (second and third generation) differ both from the native population and the host societies in terms of their religious practices. By the way, it is also interesting to note that according to the findings of the report by the Pew forum on Religion and Public life, Europe has more Christian than Muslim immigrants. The report states that the United States is the primary destination for Christian and Buddhist migrants (Pew Report 2010). The report also identifies most Christian immigrants living in Germany and Italy as coming from other European countries. A similar picture is also valid for the United Kingdom, whereas in Spain it was found that there was a large Christian migrant population from Latin America (Pew Report 2010: 28).

Religious identity is relied upon in order to maintain ethnic boundaries and culture among immigrant communities in Europe. With this in mind, the major themes that were explored by researchers were the flow of people in postmigrant societies who were concerned with adaptation, adjustment, negotiation, differentiation and institutionalization (congregational form) of identities. Warner identifies these four types of themes involving religious identity among the immigrant communities (Warner 1998). According to other research (Young and Ebaugh 200I), there are other themes in the recurrent studies on the nexus between immigration and religion. The first is the reformulation 
of religious identity that is reshaped by returning to theological foundation sources. The second, as pointed out by these scholars, the claim for a more open and universalist discourse rather than an exclusivist one, is really grounded in the immigrant activities. In some cases, there is a move from the purely ethnic institutionalization of religious identity to more cosmopolitan inter-ethnic religious gatherings. But mostly the immigrant communities transplant and settle their religious heritage and baggage in their new lands to continue and foster their transnational links with creating new spaces (Metcalf 1996), living in their ethnic enclaves. For these new-comers in the host land, their religion is a central site to remember, to rehearse the connection with the cultural-historical past, meaning that it is an important source of social capital.

As a consequence, nowadays, the 'pre-existing' secular character of the public sphere that emphasizes secular citizenship in the public realm is questioned on the one hand, with the overlapping of the ethnic-national and religious identity and the new transborder ones, while the religious identification is maintained 'as it was before' in political debates and discourses in the migrant countries in Europe. In many European countries, on the other hand, referring to religious heritage, signs and symbols of religion in the public domain (for example the crucifix in Italian public schools, public holidays, reference to Judeo-Christian principles) remains a question of identity which reveals the functional roles of cultural norms and traditions (Casanova 1994; Göle 20II).

\section{Rethinking multiculturalism: will it be post-secular and borderless?}

It is commonly assumed that public life is plural and basically secular in Europe. Multicultural policies have been used to manage cultural-religious diversity in the public sphere. At the same time, there has been rising doubt about multiculturalism; more recently its 'death' has been celebrated in most political speeches. ${ }^{2}$ These kinds of discourses question the concept of multiculturalism. The rhetoric against multicultural policy in Europe is largely shared by politicians and by public opinion (Kymlicka 2012; Prins and Slijper 2002). Arguably, multiculturalism is in perpetual crisis. The backlash from multicultural policy has been analysed in recent studies (Jopke 2004; Vertovec and Wessendorf 2010). Nevertheless, the crucial question is formulated as what kind of pluralism and diversity is possible and manageable. During the 1990 a number of scholars 
made such philosophical and political contributions on multiculturalism (Kymlicka 1995; Taylor 1994; Werbner and Modood I997).

There are many forms of ethnic-religious and cultural pluralism, and according to different understandings many states develop political models to manage cultural and political diversity from assimilation to separatism (Vertovec and Wessendorf 2010: 3-4). Grillo argues that in post-industrial societies three modes of pluralism have emerged: multicultural pluralism, institutional pluralism and hybridity (Grillo 1998: 189). These policies and forms oscillate between two main arguments: proponents of homogeneous, monocultural societies and the heterogeneous, plural model of societies (Goldberg 1998: 20). The argument against multicultural society resides in the logic of the necessary requirement to form a community, a society. The idea of homogeneity is based on two logics. First, homogeneity is a natural condition, exemplified by a socio-biological claim. Secondly, historically people find and select their category according to their tradition, customs, history and past. Homogeneity serves this continuity of a historical past and identity (Goldberg 1998: 2I). A homogeneous society and culture provide tools and means to preserve the virtues and values of the society and the group. To maintain cultural boundaries it is essential to maintain and refer to common values that have been historically transmitted. The reaction observed against migrant people who change and transform the character of public life, its values and symbols reflects a popular attitude in Europe today. The questions in the multiculturalism debates embody concern about identity issues and their visibility in the public sphere (Farrar, Robinson and Sener 2012; Garner and Kavak 2012). Exploring the multiculturalism debates in Europe permits us to see in what way transnational and transcultural identities will be formulated.

Multiculturalism is marked by the post-secular notion of public space. In this sense the rise of multiculturalism as a political ideal and liberal theory seeks to provide public recognition and support for the accommodation of non-dominant groups, to protect and empower ethnocultural groups (Kymlicka 200I). In the meantime the multiculturalism question has shifted from cultural-political peculiarities to freedom of speech, equality, democracy and state neutrality which centres on language and indigenous people. The multicultural society settles a balance between minority and majority ethnic-religious groups to afford rights to newcomers, migrant communities, and minority religious groups. It is important to acknowledge an immediate problem of the pendulum motion of multiculturalism: republican multiculturalism is blind to religious diversity and religious presence in the public realm. In this vein, the focus on neutrality, 
freedom of speech, equality, including the rights of the minority ethnocultural groups, seems to us to reveal a certain secularist blindness and bias. Hence, the public sphere's neutrality does not extend to religion. Modood objects against such non-recognition of religion in the public area (Modood 2007: 26). For him, it is impossible to defend the argument that the multicultural state model cannot be implemented in relation to religious groups (Modood 2007: 30 ).

We argue that the public sphere should be adapted, where needed and where it may be positively embedded in view of a realistic and positive pluralism, to provide greater access to and circulation of religious identities, rights and claims. In schools and other public institutions, in order to respect non-ethnocentric neutrality, one should take religious diversity into consideration and accommodate religious holidays, dress, and dietary-ritual restrictions without creating parallel societies and communities. We need a reformulation of multiculturalism which does not have an anti-religious secularist bias and is open to intercultural dialogue that brings differences together. It is important to note the idea of difference which "has to be considered in terms of how the negative element, the stigmatic differentiating from others, can be undone by bringing to bear upon it an extended concept of equality and a sense of belonging with others" (Modood 2007:36). The defence of difference is linked with the question whether multiculturalism has its limits.

For the opponent who also defends the limits, multicultural policies generate home-grown terrorism, creating space for religious fanatics, and they threaten the nation's harmony and identity. The security oriented discourses and critics developed by far-right wing parties oppose to the themes of integration. Also, some national movements and parties have often initially argued that such forms of recognition of difference are divisive of social harmony. However, the following chapters enable us to identify the distinctness of a religious-ethnic group as a feature of society just as the status of class and gender. The contemporary postimmigrant and post-secular formation of identities in western societies can be better understood in terms of hybridity and multiple identifications. Even such identities are usually expressed in self-designated hyphenations such as GermanTurkish Muslims, Polish Tartars. This indeed will be one of the themes of this book and will be developed in three chapters (Lum, Dinç, Warminska). 


\section{Content of the book}

This book is divided into two parts. In the first part, post-migrant interactions/ identifications and a range of the wider issues that are associated with identity questions are explored. The second part is entitled non-migrant, and anti-Islam interactions and identifications, and this part looks at the specific issues of nonmigrant and anti-Islam settlement and organizations.

Part one comprises five chapters. In the first, Dinç analyses the articulation of Islamic identities with wider society. The interpenetration of Islam within the European public sphere brings to the surface new debates on secularity, the sacred and intimacy. A sense of Islamic individuality appears which loses its traditional links and patterns and can be described as a transnational Islam which transgresses borders. In this process of individual choice of Muslims in Europe, Islam becomes one of the markers and aspects of the Muslim identity. Dinç describes a realization of hybrid identical patterns of Muslim youth in Germany that also demonstrate the differences with their parents representing a traditional Islamic identity. Dinç argues that experiencing this distance from their social and ethnic origins or an emotional engagement with their ethnic-cultural background accelerates a religious pluralism anchored in democratic plural German society. The transnationalization of an Islamic sense of identifying with such a network, organization and movement engenders the de-territorialization of Islam from the home country, on the one hand, and a strong connection and ties with their ethnic-national culture on the other hand. This chapter presents the neo-fundamentalist, the religious ethical exclusivist, the neo-Muslim and finally the classic associational identity as ideal-types of identity of devout post-migrant Muslims.

Juchtmans explores how Turkish children from an Islamic background compromise between home (a Muslim environment) and school (non-Muslim culture) in Flanders, Belgium. Muslim children interact at school with different people, who are increasingly made up of diverse populations, where they adopt acculturation attitudes that can be distinguished as problematic (anomaly) and non-problematic. School is perceived as a place of domination where a common non-denominational or Catholic identity is offered to the students through secular-religious rituals (such as "Santa Claus", Christmas, Mother's Day and Father's Day, carnival, etc.) inscribed in a Flemish heritage and culture. Mostly, the children participate in these festivities and adopt positive attitudes between home and school. The position of Muslim children in relation to school is 
complex and cannot be directly compromised and accommodated. The chapter indicates that being Muslim children in home-school raises particular challenges in recognizing religious diversity and acceptance of secular norms and values in school. Multiculturalism becomes a way of being.

A third chapter deals with theoretical issues on immigrant salient identities in Europe to make somecomparisons. Meciar'schapter deals with two interconnected topics - the identity of an immigrant and the process of adaptation. First, the author briefly introduces some shifts in theorizing identity (with the focus on immigrant identity) that were caused by the narrative turn in social sciences, and presents a discussion on acculturation and the adaptation process. Secondly, an analysis of adaptation difficulties is further introduced via the real-life stories of immigrants from 8 countries of the European Union. The analysis follows several frameworks of adaptation difficulties from the immigrant's subjective point of view: legal and social status, the labour market and work permits, the recognition of qualifications, the education and learning culture, housing, interpersonal conflicts, stereotypes and misunderstandings. Thirdly, the chapter attempts to outline how the adaptation issues (both, successes and difficulties) influence the formation of an immigrant identity.

What is developed in the three first chapters about Muslims is not just a Muslim issue. That is why we wanted to integrate here in this place in the book Lum's chapter on Dalit Indian youth. Lum's contribution includes elements on negotiating intra-ethnic and intra-religious identity which is problematic, as is shown in an example of the Ravidassia, considered among the lowest of the low in the regional caste of the Punjab. Lum's chapter affirms that mobility and immigration present challenges to the endurance of casticism among Ravidassia in Spain. Within the migrant community among the second generation of Ravidassia, the youth try to manage multiple identities, ethnic-religious and caste-like ones. Religious practice urges them towards ambiguous religiousethnic identification processes identified by Ravidassia as pride, intercaste mixing and being in Spain. Through daily life and music, the youth claim a new language about their caste system. Consequently, the Ravidassia youth negotiate their ethnic-religious minority identity with public influences in Spain. When the caste system is diluted via interaction with Spanish natives, the cultural juggling creates zones where multiple identities start to emerge. These zones lead to more open, tolerant citizens and plural societies.

But to what kind of plural European society will these migrations bring us in the longer term? A possible result of all these dynamics may already be seen, 
perhaps, in the case of the Polish Tartars, a small ethnic community living in Poland. Katarzyna Warminska describes a façade of multiple identities and of pluralistic society in which Tartars enjoy having bi-cultural identities oscillating between Tartar Polish ethnic identity and Tartar Muslim loyalty. Being Muslim, Tartar and Polish at the same time is challenging for this small group in the sense of cultural and religious otherness in relation to Polish society. This otherness conceived in a positive manner creates a cultural, symbolic and social capital to Polish Tartars to affirm their distinction from Polish natives. Warminska points out that they address the past and history to recast the Tartar identity in Poland for the preservation of group awareness. Having multiple identities is not mutually exclusive; rather it strengthens their loyalty to the host society through remembrance of the past.

The second part, non-migrant interactions/identifications, again has five chapters and starts with Legrand's contribution. Moving from Germany, Belgium and Poland (in the first Part) to Europe in general, within it also Austria and the Scandinavian countries, his chapter analyses Muslim visibility and European anxiety about the 'growing number of Muslims' in two ways. In the first part, he presents 'anti-Islamization of Europe' activism, including actors and events. In the second part, he explores the dialogue-counter dialogue process around some institutions and organizations to look at cultural-religious diversity and plural identity with Muslims in secular-Christian Europe.

In the next chapter, Harry, who focuses on Norway, also calls attention to the rise of nationalist movements and parties, scrutinizing the interaction between nationalism, religion and politics against multicultural politics. The socio-political analysis of Anders Behring Breivik's attacks expresses this opposition to multiculturalism, a hate of diversity and defending a vision of a Christian European community. Harry argues that the resurgence of religion in far-right politics is not an expression of old-fashioned traditionalist views but rather a contemporary reflection of the role(s) of religious identities. In this context, it is not a question of the manipulation of religion by far-right parties. It is the symbolic and cultural role of religion that is a serious part of a Norwegian historical memory that today shapes a political opposition to diversity policies. Upon close inspection of patterns of secularism in Norway, Harry argues that after Muslims became a target in integration debates, the discourse of far-right parties shifted from a secular to a religious one. The reference to Christianity as a marker of identity works as a set of memorization 
and essentialization. In both processes, individuals are disaffiliated from the pluralistic sense of society.

In the next chapter, Murat Sevencan opens a debate on the current transfer of national sovereignty to supra-national identities which generate a nationalistic discourse and policies. In order to map the contours of contemporary political transformation of European identity within the context of national identity, this chapter revisits and reflects on the transfer of sovereignty in Europe. For Sevencan, the notion of multiple identities, which is not just a normative assertion but also an empirical claim, is divided into six categories of identities built from four levels of identification.

In the last two chapters in this second part, Allen's and Nimni's, the authors challenge some restrictive interpretation of liberal secularism in Europe. Nimni details how religious minority groups organize within their religious-ethnic groups to establish a voice through religious courts. The Muslim sharia courts and the Jewish Beth Din are considered a space in which to denote autonomy and self-participation in the public sphere. The chapter exposes the relative autonomy of religious marriages in a secular area to discuss religions' role in secular policies and legal pluralism in the UK. However, as also the former chapters show, some challenges are surely justified, but it does not mean that we want to go too far in the plea for more openness. More openness, yes, but in a reasonable way.

The last chapter by Chris Allen tries to understand the crisis of multiculturalism in Britain following recent debates on terrorism, security, integration and social cohesion. He remarks that the London terrorist attacks of $7 / 7$ have catalysed the 'death of multiculturalism. He underlines that most of the debates circulating about Muslim integration and the crisis of multiculturalism have become synonymous with Islamophobia. He defines two categorical stances of antiMuslim, anti-Islam ideologies that are in existence. The first emerged from the far-right organizations. It is well structured and more explicit. The second is more implicit and non-structural. This rhetoric has more informal settings and networks that are behind this anti-Islamic discourse that is nourished mostly by secular liberal thinking and ideology.

Our conclusion will reflect on the findings of the previous chapters and the reflections of the various participants in this debate.

Finally, we want also to mention the input from the two reviewers of our publication. We cannot say that these reflections and this book are their work, but they certainly formulated very helpful suggestions that improved the quality of it. 


\section{Notes}

I See more what Habermas says on post-secular society: Habermas, J. Notes on a post-secular society, http://www.signandsight.com/features/1714.html accesdate 10/03/2013.

2 In 2008, the British PM said "Multiculturalism had dangerously undermined Britain's sense of identity and brought about cultural apartheid”. In 2010, the German chancellor claimed that the multicultural model of society had failed and the idea of people coming from different background living together side by side did not work (The Guardian, I7 October 2010).

\section{References}

Ali, N. and A. Holder (2006). 'Post-colonial Pakistani mobilities: The embodiment of the 'myth of return' in tourism,' Mobilities, I (2): 217-242.

Barth, F. (1969). Ethnic groups and boundaries. The social organization of culture difference. Oslo: Universitetsforlaget, 1969.

Barth, F. (1994). 'Enduring and emerging issues in the analysis of ethnicity', in Vermeulen, H. and Govers, C. (eds.) The Anthropology of Ethnicity: Beyond 'Ethnic groups and boundaries'. Amsterdam: Het Spinhuis, II-32.

Basch, L. N. Glick Schiller and C. Szanton Blanc (eds.) (1994). Nations Unbound: Transnational Projects, Postcolonial Predicaments, and Deterritorialized Nation-States, Langhorne, Gordon and Breach.

Baumann, G. (1999). The multicultural riddle: Rethinking national, ethnic, and religious identities. London: Routledge.

Bhikhu C. Parekh (2002). Rethinking Multiculturalism: Cultural Diversity and Political Theory, Harvard University Press.

Brass, P. (1991). Ethnicity and nationalism. Theory and comparison. New Delhi, Newbury Park, London: Sage Publications.

Brettell, C. (ed.). (2007). Constructing borders/Crossing boundaries: Race, ethnicity, and immigration. Plymouth: Lexington Books.

Brubaker, R. (2004). Ethnicity without groups. Harvard University Press.

Caglar, A.S. (1997). 'Hyphenated identities and the limits of culture', in Modood, T. \& Werbner, P., The politics of multiculturalism in the new Europe. London: Zed Books, pp. 169-185.

Carling, A. (ed.). (2006). Globalization ad identity. Development and integration in a changing world. London: Tauris.

Casanova, J. (1994). Public Religions in the Modern World. Chicago, The Chicago University Press. 
Castells, M. (1996). The rise of the network society. Oxford: Blackwell.

Cerroni-Long, L. (2007). 'Ethnicity in anthropology', Ethnoculture (e-journal), vol. I: 2-I4.

Cesari, J. (2007). 'The Hybrid and Globalized Islam of Western Europe', in Samad, Y. and S. Kasturi (eds.). Islam in the European Union: Transnationalism, Youth and the War on Terror, Oxford University Press, I08-I22.

Clifford, J. (1994). 'Diasporas,' Cultural Anthropology, v.9, n.3, pp. 302-338.

Coatsworth, J. (2004). 'Globalization, growth, and welfare in history', in M. Suarez-Orozco and D.B. Qin-Hilliard (eds.). Globalization. Culture and education in the new millennium. Berkeley: University of California Press, pp. 38-55.

Comaroff, J. and J. Comaroff (2009). Ethnicity, Inc. University of Chicago Press.

De Vos, G. (1975). 'Ethnic Pluralism: Conflict and Accomodation', in De Vos, G. and L. Romanucci-Ross, eds., Ethnic Identity. Cultural continuities and change. Mayfield, Palo Alto, CA.

Ebaugh, H.R. and J. Chafetz, (2002). Religion across Borders: Transnational Religious Network, Walnut Creek, CA:Altamira Press.

Fadil, N., (2005). 'Individualizing faith, individualizing identity: Islam and young Muslim women in Belgium,' in: Cesari J. (ed.), European Muslims and the secular state. Ashgate, pp. I43-154.

Faist, T. (2000). The Volume and Dynamics of International Migration, New York: Oxford University Press.

Farrar, M., Robinson, S. and O. Sener (eds.). Debating multiculturalism I. London: Dialogue Society.

Fischer, M.M.J. (1986), in Marcus, G.E. and Fischer, M.M.J., Anthropology as Cultural Critique. An experimental moment in the human sciences. University of Chicago Press, p. 176.

Fraser, N. (2007). 'Transnationalizing the Public Sphere', Theory, Culture \& Society, 24(4): 7-30.

Garner, S. and S. Kavak (eds.). (2012). Debating multiculturalism II. London: Dialogue Society.

Giddens, A. (1999). Runaway world: How globalization is reshaping our lives. London: Profile Books.

Göle, N. (2011). Islam in Europe: The Lure of Fundamentalism and the Allure of Cosmopolitanism. Markus Wiener Publishers.

Grillo, R. (2004). 'Islam and Transnationalism', Journal of Ethnic and Migration Studies, $30: 5$, $86 \mathrm{I}-878$.

Habermas, J. (2008). Notes on a post-secular society, in: http://www.signandsight.com/ features/1714.html. Translated from a paper written in German and published in Blätter für deutsche und internationale Politik (April 2008). 
Helicke, J. (2002) 'Turks in Germany: Muslim identity "between”' states', in Haddad, Y.Y. and Smith, J.I. (eds) Muslim Minorities in the West: Visible and Invisible. Walnut Creek: Altamira Press, 175-191.

Hervieu-Léger, D. (1996). La religion pour mémoire. Paris: Cerf.

Kivisto, P. (2007) 'Rethinking the Relationship between Ethnicity and Religion', in Handbook of the Sociology of Religion, James Beckford and Jay Demerath, eds. Thousand Oaks, CA: Sage Publications, 2007.

Kymlicka, W. (1995). Multicultural Citizenship: A Liberal Theory of Minority Rights, Oxford University Press.

Kymlicka, W. (2001). Politics in the vernacular, nationalism, multiculturalism and citizenship. Oxford University Press.

Kymlicka, W. (2012). Multiculturalism, success, failure and the future. Washington: Migration Policy Institute.

Leach, E. (1954). Political Systems of Highland Burma: A Study of Kachin Social Structure. Harvard University Press.

Leman, J. (1999). 'Religions, Modulators in Pluri-Ethnic Cities: An Anthropological Analysis of the Relative Shift from Ethnic to Supra-Ethnic and Meta-Ethnic Faith Communities in Brussels', Journal of Contemporary Religion, vol. 14, nr. 2, 217-231.

Leman, J. (2009). 'The 'empowering' impact of the internet (or the 'virtual') on Europe's immigrant Muslim minorities', in Timmerman, C., Leman, J., Roos, H. and Segaert, B. (eds). In-Between Spaces. Christian and Muslim minorities in transition in Europe and the Middle East. Frankfurt a. Main: Peter Lang, pp. 193-201.

Levey, G. B. and T. Modood (2009). Secularism, Religion and Multicultural Citizenship, Cambridge University Press.

Marcus, G. E. (1995). 'Ethnography in/of the world system: the emergence of multi-sited ethnography,' Annual Review of Anthropology, 24, 95-117.

McLuhan, M. (1962) The Gutenberg Galaxy: the making of typographic man. University of Toronto Press.

Metcalf, B. (1996). 'Introduction: Sacred words, sanctioned practice, new communities' in Metcalf, B. (ed.), Making Muslim Space in North America and Europe, Berkeley: University of California Press, I-27.

Moerman, M. (1965) 'Ethnic Identification in a Complex Civilization: Who Are the Lue?', American Anthropologist, Volume 67, Issue 5, pages I215-1230.

Modood, T. and P. Werbner (1997). The Politics of Multiculturalism in the New Europe: Racism, Identity and Community, Palgrave Macmillan.

Modood, T. (2007). Multiculturalism: A Civic Idea, Polity Press. 
Robertson, R. (1992, $\left.2^{\text {nd }} 1993\right)$. Globalization. Social theory and global culture. London, Newbury Park, New Delhi, Sage Press.

Robertson, R. (2003). 'Antiglobal Religion', in Juergensmeyer, M. (ed.). Global Religions. Oxford University Press, IIO-I23.

Stark, R. (1999). 'Secularization, R.I.P.,' Sociology of Religion, vol. 60 (3): 249-273.

Taylor, C. (2007). A Secular Age. Cambridge, Massachusetts and London: Belknap Pr. And Harvard Un. Pr.

Taylor, C. (2011). Multiculturalism. Princeton University Princeton University Press.

Triandafyllidou, A., Modood, T and A.N. Meer, (eds.). (2011). European Multiculturalisms: Cultural, Religious and Ethnic Challenges, Edinburgh University Press.

Triandafyllidou, A. and R. Ruby (eds.) (2007). European Immigration: A Sourcebook, Ashgate Publishing.

Vertovec, S. and A. Rogers (eds.) (1998). Muslim European Youth: Reproducing Ethnicity, Religion, Culture. Aldershot: Ashgate.

Vertovec, S. (2002). 'Diaspora, transnationalism and Islam: Sites of change and modes of research,' in Allievi, S. and J. Nielsen (eds.), Muslim Networks and Transnational Communities in and across Europe. Leiden: E.J. Brill, pp. 312-26.

Vertovec, S. and S. Wessendorf(eds.) (2010). The Multicultural Backlash: European Discourses, Policies and Practices. London: Routledge.

Wagner, L. B. (2008). 'Diasporic visitor, diasporic tourist. Post-migrant Moroccans on holiday at 'home' in Morocco,' Civilisations, vol. 57, nr. 1-2: 191-205.

Wagner, L. B. (2011). Negotiating diasporic mobilities and becomings. Interactions and practices of Europeans of Moroccan descent on holiday in Morocco. Doctoral thesis. University College of London, department of Geography.

Warner, R. S. (1998). 'Religion and Migration in the United States', Social Compass, 45, I, pp.123-34.

Weber, M. [1921-1922] (1978). 'Economy and Society: An Outline of Interpretive Sociology', in Roth, G. and Wittich, C. (eds.). (translated by Ephraim Fischoff et al.). Max Weber's Economy and Society. 2 vols. Berkeley: University of California Press, p. 389.

Xavier Inda, J. and R. Rosaldo (eds.). (2001). Introduction: a world in motion. The anthropology of globalization: A reader. New York: Blackwell: pp. I-34.

Yang, F. and H. R. Ebaugh (200I). 'Transformations in New Immigrant Religions and Their Global Implications', American Sociological Review, 66 (2), pp. 269-88. 



\section{Part I: \\ Post-Migrant \\ Interactions/Identifications}





\title{
CHAPTER 2 \\ New and Old Identity Patterns of Religious Young Muslims in Germany
}

\author{
Cüneyd Dinç
}

The purpose of this chapter is to develop a descriptive typology of various identity patterns of young devout post-migrant Muslims in Germany by reviewing the literature about Islam in Germany and evaluating the self-description of various religious groups. It is assumed that, first, the emotional relationship between devout post-migrants and the societies of their (grand)parents and, second, their rejection/acceptance of German society and therefore their readiness/refusal to struggle for the recognition of their religious difference in Germany shape these identity patterns. The diverging characteristics of these two dimensions establish four distinct identity patterns. Two of them - classical associational and religious-ethnic/exclusionist identity - are classical forms of identity, whereas the other two - Neo-Muslims and Neo-Fundamentalists - are new developments. These four identity patterns dominate the self-identity of young devout postmigrants. Thereby we can observe that newer identity patterns differ from classical ones first in the change of the loci of identity constitution. The classical mosque association has assigned this role to more informal associations, with the internet as a main source of identity constitution. In addition, the new identity patterns are influenced by global trends in the Islamic world and local agendas. On the other hand, classical identity patterns are influenced by the agendas of the societies of the parental generation. 


\section{Introduction}

The last decade has changed the relationship between Islam and German society. Muslims in Germany have abandoned their former invisible backyard praying rooms. Representatives of Islamic interest organizations have started to negotiate with German authorities about Islam's political and legal accommodation, including topics like Islamic education, halal meat, the role of the headscarf, the construction of Mosques, etc. (Rosenberger and Sauer 2008). In other words, Islam has become more and more visible in German public life. This 'interpenetration' (Göle 2005) of Islam with European and especially German society within the frame of a new post-secular society (Habermas 2008) has unleashed public discussions about German identity in relation to Islam and Muslims in Germany. Is Islam part of Germany? How much of Islam - as a source and symbol of 'Otherness' - can German society tolerate (Dolelzal, Helbling and Hutter 2010)?

On the other hand, these public discussions also forced Muslims in Germany to re-evaluate their relationship with German society and their own identity in that country. The third generation of post-migrant young migrants especially have never shared the migration experience of their parents and are now forced to decide who they are (Mushaben 2008a, 2008b).

Moreover, Islam in the European diaspora has also changed, losing its ties to the traditional structures and authorities, which had the monopoly of interpreting the religious scriptures. This disembeddedness of Islam has developed new forms of Islamic religiosity as a matter of personal choice and individualization (Göle 2006: 126 ). Thus, new forms of Islamic understandings and interpretations have emerged, forcing devout post-migrant Muslims to choose one of these and combine it with their ethnic or German identity (Nordbuch 2010).

The modest purpose of this chapter is to describe emerging significant new identity patterns of these young devout post-migrant Muslims in Germany by developing a typology of ideal-typical and significant identity patterns, through reviewing and re-evaluating the academic literature about Muslims in Germany. It is assumed that this typology can be constituted along two dimensions: (I) the emotional relationship of these young Muslims with the home countries of their ancestors and (2) their readiness to struggle for the recognition of their religious difference in Germany. Moreover, these two dimensions result in a $2{ }^{*} 2$ matrix, with four ideal types, which in turn are manifestations of major options for post-migrant identity construction. Though these four identity options are 
not the only identity patterns of devout migrants, it is believed that they are the dominant ones within a hybrid identity assemblage of German, Islam and Ethnic identities (Foroutan and Schafer 2009). Therefore, these four ideal types of identity provide us with valuable information about the emergence of new identity patterns of Islamic youth in Germany, and how many global and local trends have an influence on identity constitution.

Considering these points, this chapter consists of two sections. The first discusses the conceptual and theoretical preliminaries, while the second presents the idealtypical identity patterns on the basis of the considerations of the first section.

\section{The public visibility of Islam and the search by young post-migrants for identity}

The relationship between Islam and non-Islam (as the religion of the Others in Europe as well as in Germany) is characterized by the fact that Islam becomes visible by claiming, expressing and performing its religiosity in the European public space, which in turn challenges European secular modernity. This in turn results in the re-evaluation of both German and Muslim identities. European and German societies are forced to ask how far they can absorb and integrate a foreign religion and culture without destroying the foundations of Western existence. On the other hand Muslims in Europe and Germany are asking themselves how they can live their devout lives in a non-Islamic environment. In addition, they are also forced to decide who they are. Are they Muslims, Germans or Turks, Bosnians, Albanians, etc. or all these?

Young third generation Muslims are in a difficult position. As post-migrants they lack the migration experience of their parents and any real physical relationship with the societies of their ancestors (Mushaben 2008a: 509; Foroutan 2010: II). Moreover, post-migrant Muslims aged between is and 29 have experienced different forms of disintegration. First, they are disintegrated on a socio-economic level, i.e. they lack access to educational and occupational opportunities. Second, on a personal level the society in which they live forces them to deal daily with their own identity. German society compels them to decide whether they are loyal to German society or to the original culture of their (grand-) parents (Foroutan and Schäfer 2009: I2-13). Thus, while post-migrant Muslims do not know any other life than that in Germany they realize that they are not really part of German society. 
In addition, religion plays a very important role in the lives of these young post-migrants. According to the Bertelsmann Religion monitor 4I per cent of Muslims regard themselves as highly religious, compared with I8 per cent of Germans (Bertelsmann 2008: 13). Comparing the various Muslim generation one can assume an intergenerational stability of religious values, i.e. young Muslims are as religious as their parental generation (Diehl and Koenig 2009). So it is no wonder that especially devout post-migrant Muslims are particularly affected by the public discussions about Islam's role in Germany.

Finally, these young Muslims do not live in the same religious cultural environment as their parental generation. Research on Muslims in Europe demonstrates that religious identity is still for them a focal reference point for identity and political engagement (Bouzar 200I; Jacobsen 1997; Mushaben 2008a). However, third generation Muslims have a stronger personal commitment to personal piety as a matter of personal choice, and hence do not share the traditions and concepts with which their parents grew up (Gale 2009; Mushaben 2008a; Nordbruch 2010; O'Toole and Thileman 2008). Hence, Islam shares with other religions in Europe the experience of disembededness, which results in a democratic opening of the interpretation of religious texts to the public at large (Khosrokhavar 1997; Roy 2004; Salvatore 2004; Tietze 200Ib). Islam is constructed, reinterpreted and carried into public life through political agency and cultural movements, not through religious institutions. Islam in this European socio-religious environment becomes a kind of social imaginary through which Muslims construct their belonging to Islam (Göle 2006: I24-I26). Religious pluralism in Germany and Europe has transformed Islam into a multioption identity device.

The combination of socio-cultural disintegration experiences and the public discourses about the role of Islam in Germany forces young devout Muslims, who express their "Otherness" in public more than others, to evaluate their relationship with German society and to develop a new identity as Muslim within German society. Two important factors have an influence on this new identity constitution. First of all, the aforementioned heterogenetic, de-traditionalized and de-territorialized nature of Islam in Europe provides different identity options for these young Muslims. These can include a more radical option whereby the young Muslim decides to retire from public life and to associate himself with radical Islamic groups, like the Salafist movement. In contrast, the same young Muslim can decide to fight for his right as a German Muslim to be different within the legal framework of citizenship (Schiffauer 2007: 83). 
Finally, he can focus his identity on an imaginary picture of the culture and tradition of his origins but still be more or less involved in German society (Allievi 2005; Foroutan and Schäfer 2009; Mandaville 2009; Roy 2004).

Second, it can be assumed that identity constitution does not happen in an isolated environment, but is a product of socialization within organizations. For many religious Muslims mosque associations and cultural centres are places where cultural identity as a Muslim and also ethnic identity are constituted, shaped and lived (Brettfeld and Wetzels 2007; Frese 2002; Meng 2004; Şen and Sauer 2006). For instance, Şen and Sauer (2006) assume that $23 \%$ of all Muslims in Germany are members of such an organization. On the other hand both authors demonstrate that over $40 \%$ of Muslims visiting the mosque are not members of those mosque associations.

Since the events of 9/II research about Muslims has also increased in German social sciences. ${ }^{1}$ While in the beginning security related questions about the relationship between Islam and terrorism dominated the research, this was supplemented in the second half of the first decade of this century by a research about different areas of Islam and Muslims, like Islamic organizations and their members (Meng 2004; Schiffauer 2004a, 2004b, 2005; Tietze 2001a), on religiosity, religious praxis and the importance of religion in the everyday life of Muslims, especially on diverse sub populations like young Muslims (Heckmann et al. 2000; Heitmeyer, Müller and Schröder 1997; Worbs and Heckmann 2003), young Muslim women (Boos-Nünning and Karakasoglu 2005a, 2005b, 2006; Karakasoglu-Aydin 2000; Nökel 2002) or young Muslim men (Frese 2002). In addition, this qualitative research was supplemented by some quantitative studies about life worlds of Muslims in Germany, undertaken by public and private bodies (Albert 2010; Bertelsmann 2008; Brettfeld and Wetzfeld 2007; Goldberg and Sauer 2003, 2004; Haug et al. 2009; Şen and Sauer 2006; Wipermann and Flaig 2009).

On the other hand, some social scientists like Kiefer (2010) or von Wensierski and Lübcke (2006, 2010) undertaking research about Muslims in Germany with a more descriptive focus have started trying to categorize the various manifestations of Muslim life and identity in Germany by developing typologies. For instance Michael Kiefer developed a category where he differentiated between (I) non-religious young Muslims, (2) fundamental, i.e. very strongly oriented on religious traditional norms, (3) nationalistic - Islamic, and finally (4) activist-islamistic identity patterns. Focusing on various interviews with young Muslims about their lives, von Wensierski and Lübcke discovered (I) an 
Islamic biography, with a focus on the Islamic religious lifestyle, (2) a secular and non-religious biography, (3) a pragmatic Muslim biography, with a strong focus on tradition, (4) a subcultural Muslim biography, focusing on a more hedonistic artistic lifestyle, and finally (s) a criminal Muslim biography, characterized by strong disintegration and criminal experiences.

While these descriptive categorization attempts are important in order to present a more detailed picture of young Muslims, the efforts to categorize all young Muslims by using one single typology has some flaws. First of all, the disintegration experiences between religious or devout and non-religious young Muslims are not the same. For example, non-religious Muslims, not demonstrating their religiosity - their 'Otherness' - in public, are not confronted with forms of exclusion by public discourses about the role of Islam in Germany. Second, the identities of young Muslims are diverse. A single categorization of devout Muslims in only Islamic or traditional categories is not able to display these variations. Finally, religious identity patterns are not static, but fluid. Their constitution is influenced not only by local, but also by global trends and social movements like Pop Islam or the Muslim Brotherhood (Gerlach 2006).

Considering all these points a stronger focus on identity patterns of only devout religious post-migrant Muslims will be more fruitful and valuable for academic research. Three points must thus be taken into consideration. First, such a categorization of identity patterns of young devout Muslims must reflect the heterogeneity of various Islamic religious ways of life in Germany. Second, it must also consider the various identity options for them, which are in turn forms of self-reflection towards two important points: (I) their own mental relationship with German society and (2) their religious and ethnic background. Finally, it must be realized that Islamic religious identity is shaped by the existence of religious organizations in Germany, i.e. people constitute and share their identity in relation and day to day interaction with similar people.

Taking these three points into consideration, this chapter will develop a typology of young Muslim identity patterns. Therefore, the article first will re-evaluate and review the aforementioned existing and fragmented academic literature about young Muslims in Germany. The focus of this secondary analysis is on the (self-) description of young Muslims' identity. The results of this secondary analysis are used to construct a typology which integrates all these separate descriptions of young Muslims in general, and Muslim subgroups in particular, into a broader descriptive framework, i.e. the typology of identity patterns. In this vein, this typology is developed round two dimensions. The first asks how much 
young Muslims connect their own Islamic identity with the culture or ethnic background of their parents. We can assume that this can have two forms: first, the religious identity of young devout Muslims can be territorialized, i.e. their religious identity is connected with the ethnic or traditional background of their parents. These people are living and constituting their identity within a distinct transnational space, where the locus of activity is the traditional mosque. Identity and socio-political activities are focused on agendas, institutions, organizations, etc. which transcend national borders and lie outside Germany (Bowen 2004; Mandaville 2007, 2009). In the majority of cases, answers to religious questions, religious agendas and targets are formulated outside Germany. One example is the national ethnic mosque associations in Germany, like DITIIB, VIKZ, $I G M G$. Muslims and especially young Muslim people who are active in these organizations formulate their identity within these structures and have a strong connection to the agendas of the parental organization abroad.

Second, the religious identities of young devout Muslims can be de-territorialized, i.e. their religious identity can be totally cut off from the traditional and ethnical background of their parents and grandparents. These people are living in a more trans-local space of identity constituting, i.e. they share similar ideas about Islam and follow trends in the Islamic world, but act more according to local issues (Gerlach 2006: II; Mushaben 2008a: 513). They develop their own agendas which deal with their own situation in Germany as post-migrants, whether in a more radical or in a more moderate way. What is important is that these Muslims focus more on the idea of Muslim identity than on ethnic identity. They are Muslims in Germany and not just Turkish, Albanian, Arab Muslims in Germany. In many cases they are not active members of traditional Mosque organizations, but establish new forms of organizations, less hierarchical and open to all Muslims. The internet plays a very important role as a virtual sphere for information seeking, where they can gather and discuss with like-minded people (Mushaben 2008a: 516).

The second dimension of the typology asks about the readiness of young Muslims to struggle for the recognition of Muslims within German society. Devout Muslims can opt to struggle for the right to be different, believing that their future is in Germany and no longer in the traditional society of their parents. For them Islam must become an accepted way of life in Germany (Schiffauer 2007: 16). As Muslim citizens in Germany these young men and women try to find a dialogue with other non-Muslim groups and try to explain their way of life to them. For instance, the 'Open Mosque Day' on which traditional mosque 
associations open their doors to the public is such way of building trust among non-Muslims.

Contrary to this option young Muslims can decide to reject such struggle for recognition. They can believe that the non-Muslim majority will never accept their way of life, and decide to retreat from German public life, regarding German society as wicked and corrupt. Thus, they will start to create their own living space, where they are safe from the 'infidels' and 'temptations' outside their world, living their own understanding of Islam (Nordbruch 2010: 37).

\section{A typology of identity patterns of young devout Muslims in Germany}

The aforementioned theoretical and conceptual preliminaries in the second section are the basis for constructing a typology of significant ideal-typical identity patterns of young devout Muslims in Germany. In this perspective, the chapter assumes that these identity patterns represent significant options of identity construction of devout post-migrant Muslims, who evaluate their own identity within the context of public discourses in Germany about the role of Islam. Figure I presents this typology in a $2^{*} 2$ matrix constituted round the two dimensions of the territoriality/de-territoriality of Islam versus the acceptance/ rejection of German society.

The first identity pattern is the neo-fundamentalist identity, which is organized within the Salafi movement or older organizations like Cemat ul Tebliğ (Roy 2004: 232). The major characteristics of this identity pattern are that they declare the western way of life to be decadent and corrupt and therefore try to protect themselves from its influence. Moreover, they also consciously demonstrate their Otherness by following a radical interpretation of Islamic rules, like strict diet rules, dress codes, and strict gender segregation. In addition, they will isolate themselves from other Muslims, accusing them of being corrupted by the western way of life. For them, the Islamic Umma is the best of all worlds (Nordbruch 2012: 46). Thus, most young Muslims identifying themselves as Neo-Fundamentalists gather together with like-minded peers and live in an isolated parallel society (Abou-Taam 20I2). Due to the fact that these groups have very few separate mosques in Germany, the locus of identity constitution is the internet. Here distinct websites are sources of identity construction, for instance www.einladungzumparadies.de. 


\begin{tabular}{|c|c|c|}
\hline & de-territoriality of Islam & Territoriality of Islam \\
\hline $\begin{array}{c}\text { Rejection of German } \\
\text { society }\end{array}$ & Neo-Fundamentalists & Religious/ethnic exclusivist \\
\hline $\begin{array}{c}\text { Acceptance of German } \\
\text { society }\end{array}$ & Neo-Muslims & $\begin{array}{c}\text { Classical mosque } \\
\text { associational }\end{array}$ \\
\hline
\end{tabular}

Figure I - Identity patterns of devout post migrants Muslims in Germany

(Invitation to Paradise), where they can watch the sermons of German-speaking Imams (Ekkehard 2010; El-Tahawy 2008). Groups like the Salafi are especially able to give young Muslims a voice of protest and provide them with easy answers, for they have experienced cultural and structural exclusion by German society. On the other hand, Neo-Fundamentalist Muslims are also not interested in the issues and agendas in these societies (Roy 2004: 243-244). They do not see themselves as Turks, Arabs, etc. but as Muslims in Germany who speak German with each other. While they connect their own local situation in Germany with the global situation in Iraq and Afghanistan, their actual focus is still Germany, aiming for the total conversion of German society by missionary work (Abou-Taam 2012; Nordbruch 2010: 32 ).

The second identity pattern is the religious-ethnic exclusionist identity. Like neo-fundamentalist Muslims these react to exclusion experiences in German society by retreating from it. But, unlike the neo-fundamentalists, they express this not by an obviously religious way of life, but by a strong focus on the imagined ethnic and/or religious traditional society of their (grand-)parents. So they strongly focus on issues and agendas of those societies and are ready to defend the interests and 'honour' of them, despite the fact that they have little physical connection to those countries (Nordbruch 2012: 44). Unlike the neofundamentalists, they have no interest in converting German society into an Islamic one. One can describe their relationship with German society as one of indifference. They are Turks, Kurds, Arabs, Albanians, etc. living in Germany, with Islam as an important source of cultural identity (Bozay 2005; Nordbruch 2010). In the majority of cases these young Muslims are getting together in various ethno-religious mosque associations, like that of the Turkish nationalist 
Grey Wolves and the Islamic nationalist Nizam-I Alem movement, which all have organic relationships with their political parental organizations in Turkey. While neo-fundamentalists' loci of identity construction are websites in German, the loci of the religious-ethnic are the mosques, where imams and other ideologists explain the world in the language of their parents.

The third identity pattern is the so-called Pop-Islamic or Neo-Muslim identity. These young Muslims understand that they have no real relationship with the traditional societies of their parents, and hence identify themselves as German Muslims. They see their future as being in Germany and want to participate in German society as German citizens. For them Islam is an expression of their demand for recognition, a desire for participation with equal rights within the structures of state and society. The Quran serves as life guidance, as a way of coping with disintegration stress. Thus they want to integrate a more conservative understanding of Islam into German society (Gerlach 2006: II; Mushaben 2008a: 513). While these young Muslims try to follow religious rules, they do not want to be excluded due to their outlook. Therefore they try to present themselves as trendy and fashion-conscious Muslims, purchasing stylish Islamic fashion from internet shops like Styleislam. In addition they follow a more individualistic way of learning their religion. While the sources of their religion can be conservative, they try to interpret it on their own and to find ways to live life as Muslim German Citizens (Gerlach 2006: 73; Mushaben 2008: 513). Unlike the NeoFundamentalists they do not aim to convert German society to Islam. The locus of identity constitution of Neo-Muslims is not the mosque, but self-established associations like MJD. In addition, the internet and special websites and forums like Myumma, Wymoo etc. play an important role in the constitution of this post-Islamic identity. Sometimes global organizations and ideas like Lifemakers can inspire these young Muslims, but they have no real connection with these organizations. Mostly they try to adapt these ideas in the German environment.

Finally, the classic associational Islamic identity is the last identity pattern, which can be found in the various traditional mosque associations, like DITIB, $I G M G$, VIKZ etc. and their youth organizations. This identity is characterized first by strong ties with the societies of their parental generation. In many cases these classical mosque associations have strong ties with parental organizations in those countries, i.e. agendas and issues in those societies are the focus of these Muslims. Nonetheless these young people have strong ties with German society, and especially with the city in which they live; where the local mosque is regarded as a vital part of urban Muslim life. They have a positive attitude towards German 
society, due to the fact that they see their future in Germany (Meng 2004: I22). Henceforth, they react to social exclusion by German society with a more selfconfident expression of their claim to be Muslims in Germany, in a similar way to Neo Muslims. Nonetheless, for these youths the mosque is the central focus of identity constitution. Unlike Neo-Muslims they do not demonstrate a more individualistic expression of their religiosity. Their religious but also cultural identity is forged by the classical sermons of local imams, who are not from Germany. Many of these young Muslims were introduced to the associational life by their parents. Nonetheless there is still an intergenerational conflict between the older generations and the young members about the function and role of these associations in Germany. While the later see their future in Germany and want to use their organization to articulate their interests, the former have a stronger connection to their home country. In addition, young Muslims expect from their associations that the associations will participate more in social life and not limit their activities to the realm of religion (Frese 2002: 289). Nonetheless, in an association like, for example, IGMG or VIKZ, both generations are bound together by the issues and agendas of their parental organization, and here the younger Members will tolerate and accept the will of the older ones. Thus they differ again from their Neo-Muslim counterparts, with whom they share many similarities, at least about their ideas of their future in Germany (Klausen 2006; Schiffauer 2004, 2006, 2010). So the identity of these young Muslims oscillates between their traditional expressions of Islam, which they develop within associational life and their readiness to live in Germany.

\section{Discussion}

This chapter presents the neo-fundamentalist, the religious-ethnic exclusivist, neoMuslim and finally the classic associational identity as ideal-types of identity of devout post-migrant Muslims. Hence, these four identity patterns can provide us with some important insights into how globalization can affect identity constituting. First, it is obvious that two of these identity patterns - NeoFundamentalists and Neo-Muslims - have emerged in recent years. Moreover they are products of global trends within the Islamic World. The emergence of these two patterns is a different answer to the conflict between the West and Islam, societal discussion about the role of Islam in Germany being one battlefield of this discursive conflict. In addition, these new identity patterns show us that 
young Muslims are trying to find new forms of socialization in which the internet plays an important role. Even the youth organizations of the classical mosque associations are forced to open their own internet portals and forums, such as www.waymo.de which belongs to the Central Council of Muslims in Germany, at the demand of their younger members. In this sense, young Muslims do not differ very much from other non-Muslim digital natives who interact with digital technology in Germany for whom the internet is a major source of identity construction. Last but not least, we can discover that the lingua franca of all these young Muslims is German, regardless of whether they identify themselves as German Muslims or Muslims in Germany.

Second, the chapter demonstrates that these identity patterns and their organizational representations are manifestations of a glocalization process of Islam in Germany (Robertson 1992). In this vein, all these identity patterns can be characterized first by an amalgamation of local (German) and more global/ universal (Islam) cultures, ideas and issues. Young Muslims in Germany are trying to adapt their self-selected identity patterns, which serve as global Islamic guiding principles for their everyday lives, in their own societal environment. Even the radical Salafi in Germany who wants to 'save' the Islamic world from infidels still has his roots and is socialized in Germany. Thus, even if he visits Islamic countries he is still more 'German' than a native Turk, Palestinian or Pakistani in Turkey, Palestine and Pakistan. In addition, access to the internet and to satellite TV, as new sources of identity constructing, of post-migrant Muslims has especially enriched this glocalization process. Consequently, the territorial religious identity of the (grand-) parental generation has been emphasized by a more glocal and de-territorialized religious identity of post-migrants. In this vein, the four identity patterns are evolving within a glocal nexus of cultural amalgamation and trans-local belonging.

Third, young devout Muslims in Germany are forced to configure various global and local identities (ethnic, religious, national-state) into a new identity. Thus, it is safe to say that they share the same fate of being in a state of 'in betweeness' as Polish Tatars, who will be discussed in Katarzyma Warminska's chapter in this book. As with the Polish Tatars, the identity of Muslims in Germany evolves within the nexus of their being Muslims, Turks/Arabs/Bosnians etc. and German citizens. However, the differences between the two cases are the various discursive strategies of identity configuration. While the Polish Tatars are trying to establish a link between their 600-year historical past as 'native' Poles with a different religion and the idea of Polishness, Muslims in Germany are developing different 
strategies of identity configuration, which can range from the total rejection of being German to the claim to be Muslim German citizens. The fact that Muslims have more identity configurations indicates that Muslims in Germany have more options than Polish Tatars. Moreover, the emergence of various strategy options depends on the country context. Muslims in Germany are a big heterogeneous and exogenous minority compared with the small homogenous and endogamous minority of Polish Tatars. On the other hand ideas of being a German and being a Pole can be different. Muslims in Germany are aware that they will never be part of the German nation because they are newcomers and are still alien to the German cultural nation. The Polish Tatars on the other hand have adopted Polish traditions and share the similar identity of Polishness with other Poles. All these are aspects which affect the number of strategy options for identity formation.

On the other hand, it becomes obvious that in a post-secular society not only does religion re-emerge in the public sphere, but it must also learn to coexist with other religious interpretations. In the case of Germany not only must Christianity find a way of coexisting with Islam, but traditional Islam must also accept the existence of new forms of religious interpretations of Islam which are trying to shape the identity of young Muslims in Germany. Thus, Islam in Germany, as in other parts of Europe, also experiences a form of de-traditionalization, due to more democratic access to religious sculptures (Göle 2005, 2006; Roy 2004). For instance, Goedroen Juchtman in her chapter in this book about Turkish children in Flanders will demonstrate that migrants have more than one source of identity. Turkish children in Flanders circulate between the Muslim environment of their home and the secular/catholic environment of their school. Thus, they adopt new acculturation attitudes towards the non-Muslim culture and try to configure it with their Muslim identity, developing new forms of multicultural identities. Consequently, Islam in Germany is also becoming 'post-secular', losing its monopoly on lifestyle guidance, which results in the emergence of myriads of Islamic lifestyles and multicultural identities.

Finally, the case of young devout Muslims and the de-traditionalization of Islam demonstrate that post-migration societies like Germany experience a constant flux of re-shaping and re-configuring of identities, and especially ideas of citizenship and multiculturalism. As a consequence, the hybrid and glocal nature of Muslim identity challenges ideas of a binary and essentialist belonging to a society (Native/Other) and of citizenship (German/Migrant). Moreover, it becomes clear how secular and religious sources differently influence the identity constructing of young migrants. Thus, if we try to answer Johan Leman's, 
Erkan Toğuşlu's and İsmail Mesut Sezgin's question in the introductory chapter about the future of multiculturalism, our chapter suggests the idea that host societies in Europe must consider the pluralist character of migrant identity and must open their public spheres to a new traffic of ideas and identities, which also include religious ones.

\section{Conclusion}

This chapter has demonstrated that the public emergence of Islam in Germany and Muslims' claim to recognition are accompanied by passionate discussions about the role of Islam in Germany. In most cases these discussions are perceived by young devout Muslims as a form of cultural exclusion. At the same time as going through other forms of structural, occupational and educational disintegration experiences, young post-migrant Muslims in Germany are forced to re-evaluate their identity as Muslims in Germany. Moreover, this chapter has revealed that these people have different identity options, which in turn are manifested in four distinct ideal-typical identity patterns. These are constructed along the lines of the readiness of these Muslim post-migrants to struggle for recognition and their emotional relationship with the countries of their parental generation. Thus this chapter has presented the neo-fundamentalist, the religious-ethnic exclusivist, neoMuslim and finally the classic associational identity as ideal-types of the identity of devout post-migrant Muslims.

However, we speak of ideal-types as heuristic tools, which only mirror an idealistic picture of reality. It is obvious that young devout Muslims are not represented just by only one of these four ideal-types. In fact young Muslim identities can have a plethora of shades of identity, which is manifested in their everyday life. For instance, while it was said that Neo-Muslims' locus of identity is the internet and self-established associations, it is obvious that they also visit local mosques, which belong to one of the classical mosque associations. In addition, these young Muslims can have their first introduction to religion in such a Mosque, but then can decide to be more active in a more neo-Muslim association. These ideal-types can be regarded as master identity patterns, which constitute the major part of the more hybrid identity of young Muslims.

In conclusion, we can say that the chapter has demonstrated that there is no one-dimensional picture of religious young Muslims. Nonetheless the chapter's limit is its focus on only devout Muslims in Germany, which has a distinct 
composition of ethnical background (Turkey, Balkan) with a distinct form of religious tradition (Sunni Islam), while other countries in Europe have other types of Muslim populations. Further research should try to find a more comparative approach and to develop a picture of identity patterns in Europe. Moreover future research must also compare forms of identity constitution and construction between devout religious and non-religious Muslims in Germany and Europe. In this vein we can develop more elaborate identity patterns and typologies. Another important point is the fact that the internet, and especially virtual communities, is the new loci of identity constitution. While there are valuable contributions which analyse the relationship between virtual communities as sources of identity formation (Alonso and Oiarzabal 2010; Everett 2009), further research can focus on new elements of virtual communities like blogs, twitter and Facebook. Qualitative online fieldwork can provide us with new empirical data to analyse and understand the discursive differences between the various identity patterns. Despite its aforementioned limits, it is hoped that this chapter was able to provide some valuable jumping off points for further research about the life of young Muslims in Europe.

\section{Note}

I For a broad overview of the state of research see Brettfeld, Wetzels (2007). For a critical evaluation see Tezcan (2003); Allievi (2005); Dinç (2011).

\section{References}

Abou-Taam, M. (2012). Die Salafiyya-Bewegung in Deutschland. Retrieved May 15, 2012, from http://www.bpb.de/politik/extremismus/islamismus/136705/die-salafiyya-bewegung-in -deutschland

Albert, M. (2010). Shell Jugendstudie. Frankfurt/Main: Fischer.

Allievi, S. (2005). How the Immigrant has Become Muslim: Public Debates on Islam in Europe. Revue européenne des migrations internationales, 2I (2): 135-163.

Andoni, A. And P.J. Oiarzabal (2010). Diasporas in the new media age: identity, politics, and community. Reno: University of Nevada Press.

Bertelsmann. (2008). Religion Monitor 2008 - Muslim Religiousness in Germany. Gütersloh: Bertelsmann. 
Boos-Nünning, U. and Y. Karakaşoğlu (2005a). Muslimische Religiosität in der Migration. Nationale und konfessionelle Binnendifferenzierungen und die Bedeutung des Kopftuches bei muslimischen Mädchen mit Migrationshintergrund. Berlin: BMFSFJ.

Boos-Nünning, U. and Y. Karakaşoğlu (2005b). Viele Welten leben. Zur Lebenssituation von Mädchen und jungen Frauen in der Migration. Münster: Waxmann.

Bouzar, D. (200I). L'islam des banlieus - Les prédicateurs Musulmans: Nouveuax travaillerus sociaux. Paris: Syrous la Decouverte.

Bowen, J. (2004). 'Beyond Migration Islam as a Transnational Public Space,' Journal of Ethnic and Migration Studies, 30(5): 879-894.

Bozay, K. (2005). “... ich bin stolz, Türke zu sein!” Ethnisierung gesellschaftlicher Konflikte im Zeichen der Globalisierung. Schwalbach/Ts. 2005: Wochenschau Verlag.

Brettfeld, K. and P. Wetzels (2007).Muslimein Deutschland-Integration, Integrationsbarrieren, Religion sowie Einstellungen zu Demokratie, Rechtsstaat und politisch-religiös motivierter Gewalt. Berlin: Bundesministreium des Inneren.

Diehl, C. and M. Koenig (2009). 'Religiosität türkischer Migranten im Generationenverlauf: Ein Befund und einige Erklärungsversuche', Zeitschrift für Soziologie, $38(4): 300-319$.

Dinç, C. (20II). 'From “Gastarbeiter” to "People With Migration Background”: A Critical Overview of German Migration Sociology', Istanbul Edebiyat Fakültesi Sosyoloji Degisi, 22: IO2-I22.

Dolelzal, M., Helbling, M. and S. Hutter (2010). 'Debating Islam in Austria, Germanyand Switzerland: Ethnic Citizenship, Church-State Relations and Right-Wing Populism, West European Politics, 33(2): 171-190.

Ekkehard, R. (2010). 'Salafistische Propaganda im Internet', in Pfahl-Traughber, A. (ed.) Jabrbuch für Extremismus- und Terrorismus-Forschung 2009/2010. Brühl: Fachhochschule des Bundes für öffentliche Verwaltung.

El-Tahawy, A. (2008). 'The internet is the new mosque. Fatwa at the click of a mouse, Arab Insight (188): II- I9.

Everett, A. (2009). Digital diaspora: a race for cyberspace. Albany: State University of New York Press.

Foroutan, N. (2010). 'Neue Deutsche, Postmigranten und Bindungs-Identitäten', Aus Politik und Zeitgeschichte, 46-47: 9-15.

Foroutan, N. and I. Schäfer (2009). 'Hybride Identitäten - muslimische Migrantinnen und Migranten in Deutschland und Europa', Aus Politik und Zeitgeschichte, s: II- I8.

Frese, H.L. (2002). Den Islam ausleben - Konzepte authentischer Lebensführung junger türkischer Muslime in der Diaspora. Bielefeld: transcript.

Gerlach, J. (2006). Zwischen Pop und Dschihad. Muslimische Jugendliche in Deutschland. Berlin: Christoph Links Verlag. 
Goldberg, A. and M. Sauer (2003). Perspektiven der Integration türkischer Miganten in Nordrhein-Westfalen. Ergebniss der vierten Mehrthemenbefragung 2002. Münster: LITT.

Goldberg, A. and M. Sauer (2004). Konstanz und Wandel der Lebenssituation türkischstämmiger Migranten in Nordrhein-Westfalen: Ergebnisse der fünften Mehrthemenbefragung. Im Auftrag des Ministeriums für Gesundheit, Soziales, Frauen und Familie des Landes Nordrhein-Westfalen. Essen: Zentrum für Türkeiforschung.

Göle, N. (2005). Interpenetrations: L'Islam et l'Europe. Paris: Galaade Editions.

Göle, N. (2006). 'Islam, European Public Space and Civilty', in Michalski, K. (ed.), Religion in the New Europe. (New York: Central European University Press).

Habermas, J. (2008). 'Die Dialektik der Sakularisierung,' Blatterfür deutsche und internationale Politik 4: 33-46.

Heckmann, F. et al. (2000). EFFNATIS - Effektivität nationaler Integrationsstrategien zur Integration der zweiten Generation von Migranten in einer europäisch vergleichenden Perspektive. Bamberg: Europäisches Forum für Migrationsstudien.

Heitmeyer, W., Müller, J. and H. Schröder (1997). Verlockender Fundamentalismus. Frankfurt a.M: Suhrkamp.

Haug, S., Stephanie, M. and A. Stichs (2009). Muslimisches Leben in Deutschland. Nürnberg: Deutschen Islam Konferenz.

Jacobsen, J. (1997). 'Religion and ethnicity. Dual and alternative sources of identity among youngv British Pakistanis,' Ethnic and Racial Studies, 20 (2): 238-256.

Jonker, G. (2002). Eine Wellenlänge zu Gott: der "Verband der Islamischen Kulturzentren” in Europa. Bielefeld: transkript.

Karakaşoğlu, Y. (2006). 'Lebensrealitäten von Mädchen mit Migrationshintergrund jenseits von Zwangsverheiratung und Ehrenmorden - zentrale Ergebnisse der Studie "Viele Welten leben", Zeitschrift für Ausländerrecht und Ausländerpolitik, (2): 22-26.

Karakasoglu-Aydin, Y. (2000). Muslimische Religiosität und Erziehungsvorstellungen: Eine empirische Untersuchung zu Orientierungen bei türkischen Lehramts- und PädagogikStudentinnen in Deutschland. Frankfurt/Main: IKU-Verlag.

Khosrokhavar, F. (1997). L'Islam des Jeunes. Paris: Flammarion.

Kiefer, M. (2010). 'Lebenswelten muslimischer Jugendlicher - eine Typologie von Identitätsentwürfen,' in: Behr, H.H., Bochinger, C., Schmid, H. and M. Rohe (eds.), Was soll ich hier? Lebensweltorientierung muslimischer Schülerinnen und Schüler als Herau sforderung Münster: LIT.

Klausen, J. (2006). Europas muslimische Eliten: Wer sie sind und was sie wollen. Frankfurt/ Main: Campus Verlag.

Mandaville, P. (2007). Global Political Islam. London: Routledge. 
Mandaville, P. (2009). 'Muslim Transnational İdentity and State Responses in Europe and the UK after 9/II: Political Community, Ideology and Authority', Journal of Ethnic and Migration Studies, 35(3): 491-506.

Meng, F. (2004). Islam (ist)ische Orientierungen und gesellschaftliche Integration in der zweiten Migrantengeneration - Eine Transparenzstudie. Bremen: Bremer Beiträge zur politischen Bildung.

Mushaben, J.M. (2008). 'Gender, HipHop and Pop-Islam: the urban identities of Muslim youth in Germany, Citizen Studies, I2(5): 507-526.

Mushaben, J.M. (2008). The changing faces of citizenship, integration and mobilization among ethnic minorities in Germany. New York: Berghan.

Nökel, S. (2002). Die Töchter der Gastarbeiter und der Islam: zur Soziologie alltagsweltlicher Anerkennungspolitiken - eine Fallstudie. Bielefeld (transcript).

Nordbruch, G. (2010). 'Islamische Jugendkulturen in Deutschland,' Aus Politik und Zeitgeschichte, (27): 34-38.

Nordbruch, G. (2012). 'Ethnozentrische Gemeinschaftsvorstellungen', Aus Politik und Zeitgeschichte, (33): 42-46.

O’Tool, T. and R. Gale (2010). 'Contemporary grammars of political actipn among ethnic minority young activist,' Ethnic and Racial Studies, 33(I): I26-I43.

Robertson, R. (1992). Globalization. Social theory and global culture. London, Newbury Park, New Delhi, Sage Press.

Rosenberger, S. and B. Sauer (2008). 'Islam im öffentlichen Raum. Debatten und Regulationen in Europa. Eine Einführung,' Österreichische Zeitschrift für Politikwissenschaft, 37(4): 387-399.

Roy, O. (2004). Globalized Islam: The Search for a New Ummah. New York: Columbia University Press.

Salvatore, A. (2004). 'Making Puplic Space: Opportunities and Limits of Collective Action Among Muslims in Europe,' Journal of Ethnic and Migration Studies, I013-1031.

Sauer, M. and A. Goldberg (2001). Der Islam etabliert sich in Deutschland. Ergebnisse einer telefonischen Meinungsumfrage von türkischen Migranten zu ibren religiösen Einstellungen, zu Problemen und Erwartungen an die deutsche Gesellschaft. Essen: Zentrum für Türkeistudien.

Schiffauer, W. (2004). 'Die Islamische Gemeinschaft Milli Görüs - ein Lehrstück zum verwickelten Zusammenhang von Migration, Religion und sozialer Integration,' in K.J. Bade, K.J., Bommes, M. and R. Münz (eds.), Migrationsreport 2004. Fakten Analysen - Perspektiven. Frankfurt/Main: IMIS.

Schiffauer, W. (2004). 'Vom Exil- zum Diaspora-Islam. Muslimische Identitäten in Europa,' Soziale Welt, (4): 347-368. 
Schiffauer, W. (2005). 'Die "Kaplan"-Gemeinde und die "islamische Gemeinschaft Milli Görüs” - zur inneren Dynamik des Islam in Deutschland,' in A.V. Senatsverwaltung für Inneres des Landes Berlin (ed.), Islamismus - Diskussionenen eines vielschichtigen Problems. Berlin: Eigenverlag.

Schiffauer, W. (2007). 'From exile to diaspora: the development of transnational Islam in Europe,' in al-Azmeh, A. and E. Fokas (eds.), Islam in Europe - Diversity, Identity and Influence. Cambridge: Cambridge University Press.

Schiffauer, W. (2010). Nach dem Islamismus. Eine Ethnographie der Islamischen Gemeinschaft Milli Görüş.Berlin: Suhrkamp Verlag.

Şen, F. and M. Sauer (2006). Islam in Deutschland. Einstellungen der türkischstämmigen Muslime. Religiöse Praxis und organisatorische Vertretung türkischstämmiger Muslime in Deutschland. Ergebnisse einer bundesweiten Befragung. Essen: Zentrum für Türkeistudien. Tezcan, L. (2003). 'Das Islamische in den Studien zu Muslimen in Deutschland,' Zeitschrift für Soziologie, $32(3): 237-26 \mathrm{I}$.

Thielmann, J. (2008). 'Vielfältige muslimische Religiosität in Deutschland', in BertelsmannStiftung (ed.), Religionsmonitor 2008. Muslimische Religiosität in Deutschland. Gütersloh: Bertelsmann-Stiftung.

Tietze, N. (200I). Islamische Identitäten. Formen muslimischer Religiosität bei jungen Männern in Deutschland und Frankreich. Hamburg: Hamburger Institut für Sozialforschung.

Tietze, N. (200I). 'Managing borders: Muslim religiosity among young men in France and Germany, in Salvatore, A. (ed.), Muslim Traditions and Modern Techniques of Power. Hamburg: Lit.

ufuq.de. (2006). Jugendkultur, Religion und Demokratie - Politische Bildung mit jungen Muslimen. Retrieved May 15, 20I2, from http://ufuq.de/pdf/Newsletter\%206-2008.pdf von Wensierski, J. and C. Lübcke (2006). 'Junge Muslime in Deutschland,' Sozial Extra, $30(2): 17-21$.

von Wensierski, J. and C. Lübcke (2010). 'Hip-Hop, Kopftuch und Familie - Jugendphase und Jugendkulturen junger Muslime in Deutschland,' in von Wensierski, J. and C. Lübcke (eds.). Kindheit und Jugend in muslimischen Lebenswelten. Wiesbaden: Chr. HunünerKreisel; S. Andresen.

Wiperman, C. and B.B. Flaig (2009). 'Lebenswelten von Migranten und Migrantinen', Aus Politik und Zeitgeschichte, 5, 3-II.

Worbs, S. and F. Heckmann (2003). 'Islam in Deutschland: Aufarbeitung des gegenwärtigen Forschungsstandes und Auswertung eines Datensatzes zur zweiten Migrantengeneration,' in Bundesministerium des Inneren (ed.), Islamismus - Texte zur inneren Sicherheit. Berlin: Bundesministerium des Inneren. 



\title{
CHAPTER 3 \\ Connecting Home and School: on the Second Generation Muslim Children's Agency in Belgian Schools
}

\author{
Goedroen Juchtmans
}

This chapter focuses on how second generation Muslim children of Turkish descent in Belgium (Flanders) move between their home and school culture and how they deal with competing expectations from both worlds. The chapter is based on qualitative empirical case-study work on three groups of ten-year-old children attending two different Catholic schools. In general, the children as social actors adopt creative strategies to connect the two worlds. However, specific school and home contexts may interfere with children's agency. The chapter argues that the way adults at school and at home deploy their power status and introduce ethnic/ religious symbols of difference is crucial in understanding this process.

\section{Introduction}

Central to much literature on migrant children is the assumption that, in an intercultural context, migrant children are likely to be confronted with a mismatch between home and outside orientations and values (Eriksen 2003). As the previous chapter has shown for Muslim youths in Germany, this experience of mismatch also has consequences for the way migrant children are shaping their identity. Devine (2009: 523) notes that migrant children are "positioned between contrasting social and cultural worlds - juxtaposing often competing definitions of appropriate forms of identity formation and presentation." School is the primary venue in which migrant children come into contact with outside 
orientations and values. This chapter explores how Turkish migrant children, who are attending Catholic schools in Belgium (Flanders), move between their home and school cultures and how they handle competing expectations from the two worlds.

In this chapter, I focus on the possible mismatches due to differences in religious education between home and school. Turkish migrants arrived as 'guest workers' in Belgium (Flanders) during the 1960 s to meet the employment needs of the Belgian state. While the majority of these Turkish migrants were Muslims, the Belgian educational landscape had been dominated by Catholic and secular movements since its inception. How are Turkish second and third generation children in Belgium dealing with these differences in religious education or with possible tensions between these domains? How do they use their religion in that process?

In the educational domain, Muslims in Belgium can rely on a legal framework of opportunities to practise their religion. Since 1978, Muslims have been allowed to choose Islam as the religious instruction option in public schools and have been able to create their own educational network. Interestingly however, the Muslim community has not as yet made use of this legal opportunity to develop an educational network of Islamic schools. Muslim parents therefore have to opt for schools within the existing educational networks. This situation increases the risk that for Muslim children religious education at school does not fit with their religious upbringing at home. Furthermore, Islam is often presented as essentially 'other' by the media and politicians, as a threat to the secular state and its institutions, as fundamentalist and as an example of the oppression of women (Salvatore 2007; Spruyt and Elchardus 2012; Van Acker and Vanbeselaere 2011). This depiction often leads to stereotyping, politicization and oversimplification of Islam, in which Muslims are treated as a homogeneous group. At the same time, a trend is being seen among Muslims in Europe towards a transnational Islam, a more visible and outspoken involvement in the public debate and a growing demand for opportunities for Muslims to practise their religion in the public domain.

\section{The complexity of children's agency}

Until the 1970s, the European research literature on children was dominated by developmental psychology which broadly depicts children's life span as a 
universally stage-like developing process wherein individual children gradually accumulate cognitive knowledge (Piaget), moral reasoning (Kohlberg) or psychosocial behaviour (Eriksen). In reaction to these studies, childhood studies came into being in the 1970 s and 1980 s as a field of study with a concern "for the socially constructed character of childhood that involves the twin research foci of childhood as a socio-structural space and children's own perspectives as social actors" (James 2007: 263). Since then, a large body of mostly qualitative empirical research, that takes the voices of children as its point of departure, has emerged. This body also includes studies on (migrant) children and religion (for a review: Hemming and Madge 2012).

By considering children as social actors, researchers within childhood studies have acknowledged children's competences to co-create their lives and to establish agency. This means that in moving between home and school "children are in a position to influence the outcome of the negotiation process in directions, which they perceive to be favourable" (Solberg 1997: 126). Or, as Mayall (2002: 6) has put it, children are "moral interpreters of the world they engage with, capable of participating in decisions on important topics." With respect to religion, Hemming and Madge (2012) observe in the body of childhood studies four manifestations of children's agency. Firstly, children are capable of discerning the religious concepts, ideas and practices that they value more. Secondly, children "may reconfigure and renegotiate formal religious meanings and practices" (Hemming and Madge 20I2: 44). Thirdly, research has shown how children make use of different sources (religious stories, media, imagination...) to make sense of their lives or to renegotiate formal religious meanings and practices. Fourthly and finally, researchers conclude that children may develop complex religious identities that differ from their parents' or dominant representations and discourses.

However, the way children's agency has come to be portrayed in childhood research, namely as an innate capability of children, has recently been criticized as overly stressing the agency and autonomy of children in this process (Christensen and Mikkelsen 2011; Eldén 2013; James 2007; Komoulainen 2007). Therefore, it risks "simplifying and reducing the complexity of children as social actors" (Eldén, 2013). To overcome this problem an approach is needed that fully accounts for this complexity without returning to the previous images of children as passive, incompetent or vulnerable.

A first pathway to this approach has been offered by Christensen and Mikkelsen (20II), who suggest that children's agency is located, as we always find ourselves in 
place. Drawing on Casey's theory of space, they claim that places which children inhabit and traverse are not neutral, but have already become a place of particular meaning and value by means of corporeal presence and activities. By entering and inhabiting these places (f.e. school), children may influence the particular meaning and value of these places, but are also influenced by the dominant meanings and values that these places already have for other people and in society (James 2007). Furthermore, children's position and agency in Western society are historically and structurally bounded by adults (parents) and by institutions made for children (school). Put differently, the relationships between children and adults at home and at school are not equal in power. Adults, as members of the dominant group and those responsible for children's education, have more power and more opportunities to shape who the children, as members of a non-dominant group, should be and the way in which they should behave (Piontkowski and al. 2002). Moreover, in the field of intercultural interactions at school, migrant children are exposed to this non-dominant position in a two-fold way, because of their double-minority status (Devine 2009). To sum up, when researching migrant children's agency at home and at school we need to take account of this double uneven distribution of power by assessing when, where and how adults use their power to control and coerce and how children's agency and moving between home and school are affected by this.

A second consideration elaborates further on the locatedness of children's agency by emphasizing how each individual child enters different places and belongs to different overlapping groups with different conceptions of life and values. So, children's social space and agency strategies may vary not only between children, but also within children, as each place and even concrete situation may require other strategies. According to James (2007: 265), this means for childhood studies that "the children's voices that appear in our texts do not necessarily speak about 'children' or 'the child' in abstract". Acknowledgement of the cultural contexts in which children's agency occurs and is produced is thus needed. In this chapter, we therefore carefully examine the cultural context of home (or community) and school regarding religious education in order to discover the changing and different positions that children take in these contexts.

A third and last consideration relates to the abovementioned mismatch that migrant children may experience between their religious upbringing at home and religious education at school. If children are confronted with this mismatch, they get to know the society in which they grow up, as religiously divided. This experience may have different consequences. Firstly, children may 
understand the home and school domains as highly separated fields with strict boundaries between 'us' and 'them' (Leonard, McKnight and Spyrou 20II). This understanding can affect their place-making and choice-making at school or at home. Secondly, growing up in a divided society where, for example, teachers and peers challenge taken for granted religious beliefs and practices may lead to heightened feelings of uncertainty and indeterminacy. Our interest is in how migrant children actively manage such situations and to what extent they expose themselves to risks or avoid those risks in managing religious uncertainty (Christensen and Mikkelsen 2008).

To conclude, this chapter aims to show how, departing from the perspective of children's agency, children of Turkish migrants in Belgium (Flanders) actively move between their Muslim homes and their Catholic schools and handle religious differences between the two worlds. Drawing on recent childhood literature, we expect that the concrete outlook of their movements and difference management will be complex as a result of power imbalances between children and adults on the one hand and migrants and non-migrants on the other (doubleminority position), to individual and contextual differences, and to heightened feelings of (religious) uncertainty in situations of home-school mismatches.

\section{Method}

Like most childhood studies which take children's agency as their point of departure this chapter uses a qualitative empirical design that was developed for a recent European $\mathrm{FP}_{7-\text { project }}$ (REMC). In five European countries, Belgium (Flanders), Germany, Ireland, Malta and Scotland, in-depth qualitative interviews with groups of teachers, parents and children of different religious backgrounds in case-study schools were conducted (2008-2009).

This chapter uses the Belgian data for a multiple case-study work. According to Hemming and Madge (20I2: 46), this method may "engage with the logic of comparison between different cases, situations and social and spatial units" and offers "one of the best ways of adequately reflecting context." The focus is on the home-school interface of three groups of ten-year-old Turkish children (nine children altogether), attending two different Catholic schools and living in a different community context (ranging from ethnically dense to ethnically mixed). In one school boys and girls are interviewed separately. Although both Catholic, the schools vary with regard to the religious instruction option 
(Islam lessons or not) and the proportions of Muslim children, mostly with an Islamic background (from 25 per cent to roo per cent).

\section{Muslims and the religious instruction option in Flemish Catholic schools}

The educational landscape in Flanders is marked by pillarization (Tielemans 2006), or the existence of different, separate educational networks that can be publicly or privately run. Catholic schools are privately run, but are publicly recognized and funded by the Flemish Community. The educational network, the umbrella organization of all Catholic schools, attracts the majority of pupils, with 60 per cent of all primary school pupils attending Catholic schools. A longitudinal research study (SIBO survey) indicates that over five per cent of them have Muslim parents. Catholic schools in urban contexts, where most Turkish (and Moroccan) families are settled, have a higher percentage of Muslims. A recent survey found that in three large Flemish cities (Genk, Ghent and Antwerp) nearly is per cent of the pupils attending Catholic schools identify themselves as Muslim (Agirdag and al. 20II).

Given the lack of Islamic schools, Muslim parents have to opt for publicly run schools (organized by the Flemish Community or by cities, municipalities and provinces) if they want their children to attend Islamic religious education (RE). Opting for a Catholic school implies that their children will attend the compulsory Catholic RE instruction. However, a small number of Catholic schools with a high concentration of Muslim pupils have been allowed by the bishops to offer Islamic religious education as an alternative to Catholic education. In the diocese of Limburg, for example, the bishop agreed to the introduction of Islamic RE in Catholic primary schools, aimed at dealing with the inflow of Muslim children into Catholic primary schools during the I990s. Fifteen Catholic primary schools participated in the project. In 2000, a new Church policy note reduced the former autonomy of schools and bishops on this matter by demanding that Catholic primary schools with a large number of Muslim children in principle offer Catholic RE only. However, even now some schools still offer the choice between catholic religion and Islam, most of them being situated in cities in the former mining region. 


\section{Differences in school context}

The school with roo per cent Turkish children (The Gember School), situated in such a former mining region, belongs to the small group of schools that offer the choice between Catholic RE and Islamic RE. In the other Catholic school with 25 per cent Turkish children (De Tijm School), attending Catholic RE is compulsory for all children. At first sight, the reason for this difference in the religious instruction option seems solely related to the very different proportion of Turkish children. A further analysis of the school context, however, reveals another reason referring to the schools' different 'logics of practice' (Devine 20I2). These logics are, for example, apparent in the way educational values and the schools' Catholic identity are worked out in their relations with Muslim parents and children. In that respect, De Tijm School and De Gember School use very different logics of practice.

In De Tijm School, the principal and teachers considered the Turkish language and the Muslim heritage of the pupils to be subordinate to the school rules. For example, clothing that made children stand out was forbidden. This could range from 'beachwear to clothing that is explicitly vulgar and, ultimately, the principal decides what is permitted and what is not.' The rationale for this approach, as explained by the principal, shows, however, that the rule was actually directed at Muslims:

"We have included this in our school rules in order to prevent young girls wearing headscarves to school. That is not allowed within the school grounds."

In the Gember School, by contrast, the home environment of the Muslim pupils or individual orientation of the Muslim parent or child was regarded as positive and brought into dialogue with the school through parental involvement and a general orientation towards community involvement. This attitude towards communication as the norm explains not only why the principal of De Gember School supports Islam lessons at school. For him, this attitude is also a way of being Christian:

"As a Christian, the key point is 'Whatever you do for the least, you do it for me. A lot of Turks, living in this neighbourhood, are underprivileged and outcasts. Once, they came here to survive, but they never got very far. Surely, as a Catholic school, you cannot close the door on them? That they are Muslims 
becomes unimportant, then. For me, it is about being able to live with dignity and, for that, they have the right to a good education."

In the following sections, we explore how the schools' different logics of practice affect the way Turkish children design their agency and the way they handle differences and contrasting expectations between school and home. To this end, we focus on the children's positions, actions and meanings vis-á-vis two topics: school celebrations and the organization of the religious instruction option at school.

\section{School celebrations}

Both schools chose a similar ritual repertoire for annual rites, which, from both a secularand a Christian perspective, form part of the socio-cultural Flemish heritage and have found a permanent place in many families (such as Christmas, Mother's Day and Father's Day, carnival). While both schools had a substantial number of Muslim pupils, Islamic celebrations did not feature on the annual school calendar, except a visit to the mosque after the Christmas celebration in De Gember School.

Both schools also expected Muslim children to be present at these rituals. This obligation was not seen by the Muslim children as a mere duty. On the contrary, the children, in general, liked to participate in these school rituals (and in similar celebrations in the sport clubs or neighbourhood), even if this implied having to participate in, for example, a Christmas Mass.

"Each Christmas time, we go to the church with school. Then, we sing a Christmas song or perform the birth of Jesus. This year, we sang Christmas carols for the elderly in the church. The elderly sang and danced with us. That was nice! (girl, De Gember School)"

This positive attitude indicates that the Muslim children may have perceived the Christian school celebrations as not 'threatening' their Muslim identity, and therefore not as a mismatch with their religious upbringing at home, even if this may 'objectively' appear so. Two explanations for the children's perception are possible. Firstly, participating in a ritual at school require no more than passive involvement: to be present can be sufficient. Secondly, we remarked that Muslim children were especially positive vis-ád-vis celebrations that drew on 
their non-cognitive skills and bodily expressions (singing, playing and dancing). Performing the birth of Jesus, for example, had, therefore, not been experienced as an identity issue, but as a means to open up space for non-cognitive skills. Put differently, playing rather than being was, according to the children's perceptions, at the core of these school celebrations.

In both schools, the school celebrations are organized and designed by adults, leaving little space for initiatives and agency on the part of the children. Even in and beyond this bounded space, however, children succeeded in becoming active agents:

\section{"I have once printed photographs of the Christmas tree. Then, I have coloured one and hung it on the wall. But at that time, I was just a little child. (girl, De Gember School)."}

In this example, the girl is actively adopting an unknown cultural element from the school culture at home. This adoption process is driven by her spontaneous desire to repeat at home what she enjoys at school. Bash and Zezlina-Phillips (2006) refer to a similar attitude in school contexts, identifying it as a mimetic strategy, used by migrant children to declare their membership of the group and to 'blend' in. However, in our case, the moment of adoption is put in the past and is connected with being a little child, unaware of doing something 'wrong' or 'unusual'. This means that their mimetic strategy had become problematized only after the imitation attempt at home and after realizing that this imitation was not congruent with the home context. The children indicated that parents or community members had played a crucial role in this problematization process by stressing the differences between school and home and by suggesting the home as the outstanding and the sole place to ensure the Islamic upbringing of children. In the same vein, a mother (De Tijm School) explained why she agreed to her children's participation in school celebrations: "[t]hey join in at school, but in their minds and hearts and at home they always remain Muslim." In contrast to their parents, however, children did not consider school and home as separate domains, but were instead trying to connect these fields and keep moving between them. To that end, less obvious strategies than mimetic ones were considered useful. For example, one girl told of how her aunt had put up a Christmas tree at home, but had called it a New Year tree. This creative solution made it possible to adopt a ritual element from the school culture without risking problems, as a New Year tree does not refer to the Christian Christmas. 
However, not all ritual elements or practices within school celebrations were welcomed or could be creatively adopted. In that respect, a Muslim boy from De Tijm School pointed to 'the sign of the cross', a Christian practice that he felt to be highly controversial:

"[b]efore class prayers and during celebrations, they always make the sign of the cross. But we don't. My father says we are Muslims. Therefore, we are not allowed to make the sign of the cross and are thus forbidden to participate."

The appearance of the sign of the cross changes the initial positive attitude of the Muslim boy to a problematic one. Barth's (1969) theory can possibly explain why the sign of the cross functions here as a trigger in this change. According to his theory, intercultural interactions consist by definition of interactional processes of boundary maintenance and boundary definition. Following Barth, this boundary refers not to objective differences between groups, but to characteristics used by the actors as overt 'signals and emblems of differences' and as 'diacritical features that people look for and exhibit to show identity' (Barth 1969: 14). In other words, for this boy the sign of the cross functions as such a 'symbolic boundary' or 'overt signal of difference' and was, therefore, negatively emotionally loaded. Therefore, the boy refused to make the sign of the cross, and started thinking in 'we' and 'they'-terms.

Why is the sign of the cross a negatively emotionally charged symbol for Muslim children? The Muslim boy gives a clue, when he says that they are not allowed to make the sign of the cross because they are Muslims. Thus, it becomes clear that the sign of the cross is perceived as belonging to the core set of prohibitions for Muslims (as, for example, not to eat pork). Making this sign anyway is then felt to be crossing a border, as an act of blasphemy, which contradicts being a good Muslim. In her book, Politics of Piety, Mahmood (2005) states that being a good Muslim is not so much a question of believing in a set of dogmas as a 'way of being' (see also Jansen 2011). Following Mahmood (2005), refusing to make the sign of the cross does not therefore express disbelief in Jesus Christ, as this interpretation would stress the Western idea of religious practice as an outward representation of an interior mental state or belief. Instead, Mahmood claims that for Muslims religious practices or prohibitions have another aim or telos and must be primarily interpreted as fulfilling a religious duty. By fulfilling these religious duties, a Muslim becomes what he/she wants to be: a good Muslim (Jansen 20II). Or it is by actually refusing to make the sign of the cross that one 
becomes a good Muslim. This insight also sheds an interesting new light on this case, because it then reveals how the refusal offers the boy the basis and potential actually to achieve what he intends to be: a good Muslim. Intentions rather than a prescribed set of beliefs are thus crucial. While in the previous cases this intention was never felt to be threatened, the 'sign of the cross' here did threaten, resulting in a mismatch which was felt to be irreconcilable between the religious norms at home and at school.

\section{Provision of the RE option: Islam lessons or not?}

I. Islam lessons in the Gember School: how to deal with community influence? The Islam lessons in the Gember School were given by a teacher belonging to the same ethno-religiously community as the children. Consequentially, the community entered the school domain and obtained space and power to influence the children's religious education. Originally, however, the neighborhood and also the school was built for a diverse ethnic population of Turks, Greeks, Italians and Flemish subterranean mine workers and their children. After the collapse of the mining industry, this picture underwent major changes. Greek, Italian and Flemish families and even a lot of Turkish families moved away. Hitherto, only the Turkish families with the lowest socio-economic status have stayed.

Comparing the boy and girl groups interviewed, we found that religion was very important for both and that they liked the Islam lessons or discussing the best way of performing a ritual or the meaning of religious practices:

"Islamic RE is something different: it is something about us. Mathematics, on the other hand, is something we have to use when we are grown-up, for our job."

However, boys and girls differed in the way they evaluated the rules and bans of their own community, revealing the girls' attitude to their Islam teacher or to their community as more complex.

\footnotetext{
"A: I don't like it if the hocha (=Islam teacher) is bad tempered. He always shouts at us, then.
}

B: But he isn't like that. 
A: Sometimes he is very nice. At the play yard, you can already see if he is moody or not. If moody, he shouts and tells us how naughty we are. If he is good tempered, we get very nice lessons."

In this case, the girls criticize the teacher's behaviour while at the same time toning down this criticism by insisting that the behaviour is dependent on the teacher's mood and not on his character. This complex position can be explained from two angles: firstly, as a way of handling a mismatch between the teaching methods of the class teacher and those of the Islam teacher and, secondly, as a way to avoid heightened feelings of insecurity vis-à-vis their community and parents. The first explanation should be placed in the context of other statements by the children, who did not want more Islam lessons and preferred the more interactive teaching approach of their class teacher, an approach they did not always find in the Islam lessons at school or at Koran school. In that context, their critical attitude may reveal their wish to integrate the class teacher's methods into the Islam lessons. The second explanation looks at the citation from its community context. Living in an ethno-religiously dense school context and neighbourhood implies being exposed to tightening implicit social control mechanisms, especially for girls. Identifying yourself as Muslim and respecting the Islam teacher are not only taken for granted, but are also considered as strict community rules on which members are regularly informally supervised and checked by others.

"Sometimes in class a fellow pupil shouts: "Who believes in Allah?" Then, you have to hold up your finger. Everybody does. You have to believe strongly in our community."

"My mother says: If you decide to stop being a Muslim, you are no longer my child."

"In our community everybody knows everything. If someone gets a car accident, the whole community will know the news immediately."

It is interesting that, in this community context, the girls choose not to adopt a consistently critical attitude, nor an uncritical stance regarding the teacher's behaviour (as the boys did). This strategy had two advantages. Firstly, it avoids a problematic identification with their religious identity and their community. Furthermore, it makes it possible safely to express their feelings and wishes regarding their Islam lessons and the preferred teaching style. 
Girls are also confronted with a range of prohibitions around their bodies, which go against Flemish habits for girls.

A: Nearly everything is forbidden. You are not allowed to do this or that: no rings, no nail polish, no earrings.

B: I have nail polish anyway. They don't see it, because it is transparent.

In this example, we see how a girl tries creatively to find her way in a context that is experienced as limiting and restricted. By using transparent nail polish, the girl succeeds in opening space for what she wants without confronting the frontiers of the prohibition and without risking punishment. Despite the prohibition, the girl is thus attempting to bridge the two worlds. In that sense, she acts as a mediator (Withol 1998), who seeks to bridge conflicts between the values of both worlds. Acting as a mediator also implies that the girl does not reject her Muslim upbringing. This attitude would be ineffective because, for all of these girls, it is precisely Muslim prayers and reading the Koran that provide considerable comfort and a buffer against insecurity and indeterminacy.

"A: If you have problems, Allah is there. You don't see him, but even then he helps you when reading a piece from the Koran or when praying.

B: I'm afraid of the dark. Then, I can't sleep. At such moments, I ask my mother to read the Koran. So I'm able to fall asleep and to be without creepy dreams."

In that way, the case of the transparent nail polish is not an example of losing Muslim religion. Rather, we interpreted this case as a resistance to ethno-religious practices that restrict the girls' agency or, as Abbas (2004, in Ipgrave, 2010) has suggested:

"Is it possible that these girls, who identify themselves explicitly as Muslims, are searching for a 'proper' and 'beautiful' Islam rather than the apparently outmoded religious practices of their parents?"

Following Dinç's typology (see chapter 2), the girls thus seem to prefer the NeoMuslim identity position. 
2. How to deal with Catholic RE at De Tijm School?

De Tijm school is an ethnically mixed school with two dominant groups: Turkish pupils with an Islamic background and Flemish children with mostly a catholic background. As a Catholic school and in line with its school policy, De Tijm School insists on Catholic RE. In general, the Muslim children did not problematize attending Catholic RE. However, the way in which their teacher dealt with this subject was discussed:

"When we learned in biology that we come from monkeys, a classmate asked the teacher: 'But, in religion, you said that we came from dust, and now you're telling us that we come from monkeys?' Our teacher answered that what is written in the Bible isn't to be taken literally."

In this case, the children point to an underlying tension between scientific/ secular and religious world views on the creation of the world. The teacher, who teaches religion as well as biology, resolved this tension by presenting these different world views separately. Religious topics or questions were reserved for the religion lessons, the scientific knowledge on this theme for the biology lessons. During the interview, the Muslim children criticized this separation and especially the silence about their religious views in the biology lessons.

In that context, Ipgrave (2010: 18-19) pleads for an epistemology-based inclusion of Muslim pupils' religious capital and theological thinking:

"Religious students should be able to feel confident that, for example, their ideas about the existence of a guiding transcendent power behind the creation of the universe or the movement of human history will be taken seriously and not dismissed as relics of a bygone age ... A truly inclusive approach requires a degree of reflexivity on the part of those (teachers and students) who do not share the religious views of some of the class members."

While the case reveals that the Muslim children interviewed were also in favour of such an approach, their position changes when asked if they would like to have Islam lessons at school:

"If I could choose Islam, I wouldn't say: No, I don't want it, but if I couldn't choose Islam, I wouldn't insist on getting it." 
One possible explanation for this avoidance strategy relates to the educational approach of the school that placed emphasis on discipline and good moral attitudes, and obedience to the school rules. Given this approach, the Muslim children's reaction may be the result of a (perceived) assimilation pressure. Without such pressure, they would perhaps adopt a different position. In short, what children do in concrete situations does not always coincide with what they think or what they would really like to do. Whether this is the case largely depends in practice on the way in which the school handles its position of power in its interactions with children.

\section{Conclusion}

In this chapter we investigated the different movements of three groups of Muslim children between two significant domains: home and school. In this concluding section, we will try to understand the complexity and changeability of Muslim children's movements.

In general, the question 'how can I become a good Muslim?' emerges as crucial, since the children's attitudes were mainly based on the way they answered and handled this question. Put differently, beneath their attitudes a foundational intention to become a good Muslim can be distinguished. For children with a Muslim education at home who are attending a Flemish school, this question needed, however, to be changed into the following, more complex one: 'how can I become a good Muslim in a non-Muslim school context?', because attending Flemish schools will affect the way in which children try to become good Muslims. Practices from home which are taken for granted and which are guiding them to this end are mostly 'absent' in Flemish schools. Moreover, Muslim children become familiarized with a set of host practices. The positive basic attitude to these practices indicates that Muslim children believe that it is possible to participate in school activities and in some cases even to adopt ritual elements of the host culture without becoming 'bad' Muslims or without contradicting their intention to become good Muslims. This is an interesting pattern, which merits more attention. As Mahmood (2005) stressed in her analysis of pious women, for these women religious practices are not experienced as mechanical acts. Religious intentions are important: the rituals are carried out with the intention of 'living modestly' (Jansen 20II). Within this intentional framework, reflexivity thus becomes possible, albeit within conservative frameworks, because every 
(new) practice can be valuable as long as it is experienced as an effective way of 'living modestly'. The Muslim children's attitudes can be interpreted in a similar way. Here, the intentional framework is, however, guided by the desire to become a good Muslim. This intention is therefore at the root of their agency. In the previous sections, we offered examples of Muslim children using this intentional framework as a space not only for reflexivity, but also for exploration, flexibility and creativity, and as a means of connecting and moving between home and school or of risk management.

However, on the basis of specific interactions with significant others at school (the case of the sign of the cross, the case of the moody Islam teacher) or at home (the case of the transparent nail polish), the way in which children move between different fields and manage differences becomes problematized, leading to a shift from positive basic attitudes to other, more complex ones. We have found that this shift is always preceded by a (perceived or experienced) restriction in agency and space to explore for the children, with avoiding or resistance strategies on the children's part as a result. In this process, (stories about) the school or parents' actions played a crucial role; as in most of the cases, the shifts were effected by school staff or parents who had pointed to irreconcilable differences between home and school culture or had devalued or silenced their religious capital. As recent childhood studies suggest (Eldén 2013), a lack of power balance between children and their parents on the one hand, and between pupils and the school on the other, is at the root of this process, as their double non-dominant position hampered the children in keeping moving between home and school.

How can schools help Muslim children in their desire to connect and mediate both worlds? We agree with Ipgrave (2010) when she focuses on developing a degree of reflexivity on the part of those (teachers and students) who do not share religious views, along with an inclusive approach in which children's religious (or secular) heritage is effectively valued as religious/secular capital. This reflexivity and valorization of each other's richness, however, require not only the act of selfcritical thinking regarding one's own views and the use of power. Also needed is the capability of together - staff, parents and pupils - imagining ways of connecting different, sometimes conflicting, fields, views and practices without avoiding or problematizing the change that this connecting will bring for each group. 


\section{References}

Abbas, T. (2004). The Education of British South Asians: Ethnicity, Capital and Class Structure. Basingstoke: Palgrave-Macmillan.

Agirdag, O., Hermans, M. and M. Van Houtte (201I). 'Het Verband tussen Islamitische Religie, Religiositeit en Onderwijsprestaties', Pedagogische Studiën, 88: 339-353.

Barth, F. (ed.) (1969). Ethnic groups and boundaries: The social organization of culture difference. Boston: Little, Brown.

Bash, L. and E. Zezlina-Philips (2006). 'Identity, Boundary and Schooling: Perspectives on the Experiences and Perceptions of Refugee Children,' Intercultural Education, I7(I): II3-I28.

Christensen, P. and M.R. Mikkelsen (2011). 'There is Nothing Here for Us...! How Girls Create Meaningful Places of Their Own Trough Movement,' Children and Society, 27(3): 197-207.

Christensen, P. and M.R. Mikkelsen (2008). 'Jumping off and being careful: children's strategies of risk management in everyday life', Sociology of Health \& Illness, 30(I): II2-I30.

Devine, D. (2009). 'Mobilising Capitals? Migrant Children's Negotiation of their Everyday Lives in School', British Journal of Sociology of Education, $30(5): 52 \mathrm{I}-535$.

Devine, D. (2012). 'Practising Leadership in Newly Multi-ethnic Schools: Tension in the Field?', British Journal of Sociology of Education, $33(\mathrm{I})$ : I-20.

Eldén, S. (2013). 'Inviting the messy: Drawing methods and 'children's voices", Childhood, 20(I) 66-8I.

Eriksen, T.H. (2003). 'Creolization and Creativity', Global Networks, 3(3) 223-237.

Hemming, P.J and N. Madge (20I2) 'Researching children, youth and religion: Identity, complexity and agency', Childhood, I9(I): 38-5I.

Ipgrave, J. (2010). 'Including the religious viewpoints and experiences of Muslim students in an environment that is both plural and secular,' Int. Migration \& Integration, II(I): 5-22.

James, A. (2007). 'Giving Voice to Children's Voices: Practices and Problems, Pitfalls and Potentials,' American Anthropologist, 109(2): 26I-272.

Jansen, Y. (20II). 'Postsecularism, piety and fanaticism: reflections on Jürgen Habermas' and Saba Mahmood's critiques of secularism,' Philosophy Social Criticism, 37(9): 977-998.

Komulainen, S. (2007). 'The ambiguity of the child's voice in social research', Childhood, I4 (I): II-28.

Leonard, M., McKnight, M. and S. Spyrou (2011). 'Growing up in divided societies: confronting continuity and change,' International Journal of Sociology and Social Policy, 3I (9/10): 520-530.

Mahmood, S. (2005). Politics of piety: the Islamic revival and the feminist subject. Princeton, NJ: Princeton University Press. 
Mayall, B. (2002). Towards a sociology for Childhood. Maidenhead: Open University Press. Piontkowski, U., Rohmann, A. and A. Florack (2002). 'Concordance of Acculturation Attitudes and Perceived Threat,' Group Processes \& Intergroup Relations, 5(3): 221-232.

Salvatore, A. (2007). 'Authority in question: secularity, republicanism and 'communitarianism in the emerging Euro-Islamic public sphere,' Theory, Culture and Society, 24(2): 135-160.

Solberg, A. (1997). 'Negotiating childhood: Changing constructions of age for Norwegian children', in James, A. and A. Prout (eds.) Constructing and reconstructing childhood. London: Falmer Press, I26-I44.

Spruyt, B. and M. Elchardus (2012). 'Are anti-Muslim feelings more widespread than antiforeigner feelings? Evidence from two split-sample experiments', Ethnicities, 12(6): 800-820.

Tielemans, J. (2006). Onderwijs in Vlaanderen. Structuur - Organisatie - Wetgeving. Antwerp: Garant.

Van Acker, K. and N. Vanbeselaere (2011). 'Bringing together acculturation theory and intergroup contact theory: Predictors of Flemings' expectations of Turks' acculturation behavior,' International Journal of Intercultural Relations, 35, 334-345.

Withol de Wenden, C. (1998). 'Young Muslim Women in France: Cultural and Psychological Adjustments', Political Psychology, I9, I, I33-146. 


\title{
CHAPTER 4 \\ Immigrant Identity, Social Adaptation and Post-Secular Society in Europe
}

\author{
Marcel Mečiar
}

This chapter deals with several interconnected topics - the social identity of immigrants, the process of adaptation and changes in identity construction. First, the author briefly introduces some shifts in theorizing identity (with the focus on immigrant identity) that were caused by the narrative turn in social sciences, and presents a discussion on acculturation and the adaptation process. Second, an analysis of adaptation difficulties is further introduced via the reallife stories of immigrants from 8 countries of the European Union. The analysis follows several frameworks of the adaptation difficulties from the immigrant's subjective point of view: legal and social status; the labour market and work permits; the recognition of qualifications; education and learning a new culture; housing; interpersonal conflicts; stereotypes and misunderstandings. Third, the chapter attempts to outline how adaptation issues (both successes and difficulties) influence the formation of immigrant identity. The last section of the chapter discusses how the formation of immigrant identities has changed in the post-secular condition. The concept of post-secular society is not understood as some kind of totally 'new' reality that is somehow significantly different from a previous 'secular' reality (Moberg, Granholm and Nynäs 20I2: 3), but rather as a reflection of the apparent contemporary resurgence of religion in the public sphere. 


\section{Social identity, adaptation strategies and narratives}

In this section, the theoretical background and the interconnections between the concepts of social identity formation (in sociology), adaptation strategies and narratives as a medium for identity research will be discussed.

Szaló (2003), when introducing his own perspective on social identity formation, follows social constructionist principles and post-structuralist conceptions about language, knowledge and power. In doing so, he "brings back to life" the social identity of an individual when - in agreement with Peter L. Berger and Thomas Luckmann (1966) - he places it among the elements that form the social reality and not among attributes merely derived from heterogeneous social processes. The self-identity of human subjects and configurations of their social identities are therefore "inevitably connected to meanings, practices, and experiences that are constituted by particular discourses and institutions" (Szaló 2003: 13). He further distinguishes between self-identities which "refer to the forms of self-cognition that is formed by reflexive discursive practices", and identity-types which "refer to the forms of knowledge that is constructed by discursive practices that constitute typification schemata relating to people in general."

Social identities are then understood as particular identity-types that "typify/ classify individuals by referring them to collectivities" while the typification schemata come from a discourse I.) describing individuals as elements of collectivities (larger social groups), and 2.) articulating knowledge about the meanings of belonging to a particular collectivity (Szaló 2003: 16-17). Social identity can be viewed analytically from the perspective of social categorization (i.e. cognition, labelling, and classification of others according to identity-types e.g. a woman, a teacher, French) and group identification (i.e. identification with a group, acceptance of a particular identity) (Jenkins 2000).

After a brief introduction to the concept of socially and discursively constructed identity we will focus on the concept of acculturation and adaptation of the identity-type (social category) of an immigrant.

Scholarly literature dealing with acculturation and adaptation shows that two dominant aspects of acculturation - a) preservation of one's heritage culture and b) adaptation to the host society - "are conceptually distinct and can vary independently" (Liebkind 200I in Phinney et al. 2001: 495). Emerging from these two analytical distinctions that can be turned into the real life question of a newcomer ( $\mathrm{A}=$ "my cultural heritage" and/or B = "integration to society"), 
the four acculturation strategies have been identified - integration $(A+, B+)$, assimilation (A-, B+), separation (A+, B-), and marginalization (A-, B-) (Berry 1997: 9-10). The concept is based on Berry's acculturation model, which distinguishes between assimilation, integration, rejection and deculturation. Phinney's acculturation strategies follow four slightly different categories: I) an individual who retains a strong ethnic identity while also identifying with the new society is considered to have an integrated (or bicultural) identity. 2) An individual with a strong ethnic identity while not identifying with the new society constructs a separated identity. 3) Another type, in which an individual who gives up an ethnic identity but identifies with the new society, results in an assimilated identity. 4) The individual with no identification with either has a marginalized identity (Phinney et al. 2001: 495).

When approaching the relationship between adaptation (as a question of belonging) and ethnicity, Floya Anthias (2002) chooses to fight the cultural essentialist weaknesses in understanding social identities with her own conceptual weapons. Methodologically, she uses a narrative (told stories) to reach her concept of translocational positionality, which refers to placement within a set of relationships and practices that implicate identification and 'performativity' or action. These relations and practices refer to social position (as a set of effectivities, as outcome) and simultaneously to social positioning (as a set of practices, actions, meanings, as a process). The concept of translocational positionality then leads to the observation that "issues of exclusion, political mobilization on the basis of collective identity and narrations of belonging and otherness cannot be addressed adequately unless they are located within other constructions of difference and identity, particularly around gender and class" (Anthias 2002: 502).

Similarly, Anna De Fina (2000) focuses on a narrative in her study of immigrant identity. She considers language to be the discursive practice that has an influence on shaping identity. Discursive practices reproduce and constantly form social relationships and socio-cultural constructs that people use to give sense to the reality around them. De Fina shows how the formation of ethnic identity takes place in the narratives (of Mexican immigrants in the U.S.A.) to a large extent built on defining the boundaries against other ethnicities, or at least on mentioning people's different origins in their stories from a new society. De Fina further states that "the ethnic mentions are used in the stories to affirm certain characteristics of one's identity and the identity of others via the presentation and evaluation of behaviours" (2000: 154). Identity (its ethnic component, or rather constructs and 
boundaries connected to it) is a major point of orientation in society - especially in the multiethnic and multicultural environment.

Thus, the practical question asking how we can empirically study identity finds its answer in the concept of narrative. A narrative emerging from telling stories is a universal human institution and also a means of 'carrying' and manifesting discourse. Anna De Fina (2000) regards narrative as a discursive practice that creates, reproduces and continuously shapes "the social relationships and sociocultural constructs that individuals use to make a sense of their reality" (Foucault 1975 in De Fina 2000: 133).

\section{Immigrant adaptation in stories of "a good practice"}

The study follows, re-evaluates and widens the scope of a practitioner-oriented project supported by funds from the EU. Within the project entitled Trainers for European Citizens, team members from eight European countries - working as pedagogues, trainers and social workers - conducted biographical interviews with immigrants who were at the time in the process of adapting to their host societies. The TEC project team gathered 23 biographical interviews in 2003 with immigrants from eight European countries (Belgium, Czech Republic, France, Lithuania, Germany, Greece, Spain and Sweden). This effort brought up a set of narratives containing the biographical reflections of so-called 'good practice' - i.e. successful adaptation to a host society.

The research resulted in both new teaching tools for trainers and theoretical conformation of the complexity of migration, and of hardship (difficulties) in adaptation. The people who shared their stories with the research team represented all types of migration as they were classified in migration studies (Castles and Miller 1993). The narrative methods also helped to display the dynamics and changes in the adaptation process.

In this chapter we will not focus on the reasons for migration, but on the subjective perspective of an immigrant during the process of adaptation. Let us summarize briefly some aspects of the lives of immigrants in the new (European) society. The stories of individual actors can be seen in life stories that follow the original trajectories, each follows his or her own path, and each of them is independent and uniquely individual. However, it may be possible to reveal some similar or shared experiences and difficulties in their life stories. 
I. Immigration policy and the question of (not just legal) status. The crucial issue for an immigrant in a receiving country is the legalization of stay (residence permit) on which access to the labour market (legal employment) heavily depends and which may lead (in different legal systems after varying numbers of years) to acquiring citizenship. The social status of an applicant for a residence permit also determines a way of acquiring the residence permit. There is certainly a difference between the social position of a student, highly qualified specialist, unqualified worker or a refugee. In some cases it takes several years to achieve the status based on residence permits.

During their long-term process of negotiation with the state bureaucratic apparatus, immigrants may experience unpleasant and unsettled feelings about the result of their efforts to obtain legalization.

"Some two years ago we were even threatened with deportation to Sri Lanka because our asylum was not recognized, but a supportive circle of our friends and relatives was formed to stop us from being deported and to speak up for us in our struggle for permanent residence. A petition was drawn up and given to the parliament of the Federal State of ..., pointing out our level of integration and the trauma we have suffered [both were still undergoing therapeutic treatment at the time of the research]. After the medical reports had been submitted, officials prolonged our stay. At the end of 2003, we have to again take our latest health details to the immigration office to extend our stay again. So, even after almost Io years then, we still do not have permanent residence status. It is hard to make bigger life plans in this kind of situation. We are well integrated, we work and pay taxes, we can speak German, but it seems that it isn't enough." [Asylum seekers and a married couple Prem and Cynthia, both aged 56 years. Country of origin: Sri Lanka, receiving country: Germany. Narrative focus (=Nf): $200 \mathrm{I}$ and mid-2003.]

The case of a married couple from Sri Lanka who came to Germany as political refugees points to the discrepancy between 'actual' adaptation and the decision process of granting permanent residence status (i.e. the possibility/impossibility of permanent residence). The story of Prem and Cynthia is significant in terms of adaptation theory. Employment, the ability to communicate in the officiallanguage and integration into informal networks (friends, acquaintances willing to help with the petition) do not seem to be enough to grant them a permanent residence permit. The subjective qualities expressed by a sincere effort in the development 
of cultural (German) and social (religious contacts in the organization and participation in non-formal education) ties stand in contrast to the solid walls of the immigration policy so far of "the most populous country in Europe" (Ringen 2003: 555). Although countries with high numbers of asylum applications tend to have stricter criteria and lower recognition rates for asylum claims (Neumayer 2005), the situation of well-adapted, integrated immigrants seems to concur with the findings of the German refugee interest group Pro-Asyl (Kopp 2000 in Neumayer 2005: 64), arguing that the chances of becoming recognized as a refugee depend on the country in which the claim is processed if significant cross-country differences in asylum recognition rates are taken into account.

As research has shown (Phinney et al. 2001: 500) social adaptation may depend more on local circumstances, personal relationships, and activity settings in economic terms. Nonetheless, national policies regarding the state recognition of immigrants are equally relevant. In this paradoxical case, the adaptation strategy of integration was not accompanied by parallel inclusion expressed by relevant legal status.

2. Employment and the labour market. Finding employment is another important aspect of an immigrant's adaptation process that is usually hard to achieve. In cases where a special organization works with qualified professionals who can offer assistance, job hunting is more successful. The refugee co-ordinator of the immigration unit (Ahmad) played an important role in the successful adaptation of the newcomer (Hussein) in terms of maintaining his client's self-esteem, in the following example from Sweden.

"I made contact with Hussein. Together we went to the employment agency to register Hussein for work. Hussein quickly made new friends and was also able to visit his cousin who lives in Stockholm. Nevertheless, Hussein felt sad and he could not really enjoy his new life. I realised that Hussein had to find a job, because his whole identity and motivation depended on his chances of finding a job and doing his share. It seemed to be more important to him to have a job than to be able to speak Swedish." [Ahmad (about Hussein), Iraq - Sweden. Nf: 2003]

The specialized counsellor, in addition to the permanently established organizations and projects working with immigrant groups, confirms the importance of social support in the search for a job. More importantly, having a 
job and doing one's share (for a society) became a necessary motivational factor for the formation of a person's integrated identity and preserving "the sense of belonging" (Maydell-Stevens, Masgoret and Ward 2007: 186).

Unemployment has an influence on the psychological condition of an individual and the social aspect of his or her existence (deprivation, inferior status both as an immigrant and an unemployed person, or a voluntary closure). Occupation can even be seen as a personal "salvation" because a newcomer desires not only to be economically independent, but also useful.

"I love the job - and for a variety of reasons. I have always believed that helping other people is an important task.... I also need the job to keep body and soul together, of course! After finishing the two Dutch courses and the course at ..., I had no further prospects and ended up sitting at home waiting for a second interview with the Belgian Immigration Service to be recognized as a refugee. I had no job offers at all until a consultant at the ... [a social agency] spotted this and advised me to apply for a job at ..., which turned out to be my salvation! My job is not only useful, necessary and interesting, but it is also my life." [Khaldoun, age 3r. Iraq-Belgium. Nf: 2003]

Khaldoun, who studied English language and literature (in his native Iraq, later in Yemen, and in the United Kingdom), is an example that defies the conventional notion of immigrants with employment below their qualifications. Certain numbers of immigrants, however, do not get a job in the same field or at the same qualification level (Vinokurov, Birman and Trickett 2000). "Immigrants are generally bunched at the two extremities of the skill spectrum - the professional and the unskilled (the immigrant workers may have been skilled in his or her place of origin but become de-skilled through migration)" (Harris 2000: 95). According to Harris, there is competition between native and immigrant in professions, whereas unskilled workers do not compete with natives for the same jobs. For that reason, unemployment rates tend to be higher for professional than for unskilled immigrants (Harris 2000).

Several interviewees talked about a specific social practice at employment bureaus that had to offer a job first to an applicant with citizenship.

"At this time we also received our work permits, allowing us to find employment. In practice, this proved to be more complicated: as soon as we managed to find a job, we had to inform the employment office to receive permission only for 
that vacant job offer. But, instead of giving us the job, the office would use this information to provide jobs for German applicants." [Prem and Cynthia, both aged 56 years. Country of origin: Sri Lanka - Receiving country: Germany. Nf: 1994-1995.]

Another qualified immigrant (a sport manager) had to face a similar problem when - after a voluntary internship during his studies - his potential employer offered him a full-time contract. The struggle for the well-paid job he was very well qualified for lasted for over two years. The employer was able to wait for all this time because Diallo could work part-time on the basis of his student status. In France, in order to recruit a foreigner an employer first has to let the National Employment Agency (Agence National pour l'Emploi) know about his offer. If after six weeks no French candidate, or citizen of the European Union, has been found who meets the job requirements, then the employer can make a request for a work permit for a foreigner.

"So then, with the support of my employer, we embarked upon "a submission for a legal decision." The first request dated from 1999. We were then in 2000. The response came back. Finally, permission to work had been given! But we were nearly into 2002!" [Diallo, age 32, Senegal - France. Nf: 1999-2003]

The question of finding and obtaining suitable employment is closely linked with the following problem of the recognition of qualifications acquired in other countries.

3. Recognition of diplomas and documents for qualification. Many European countries have a problem with the recognition of foreign diplomas and other certificates of qualification. A qualified person whose diploma is not validated in the receiving country is often forced to take a job requiring lower qualifications (Harris 2000). Some newcomers may have difficulty in obtaining proof of qualifications if they were forced to flee their countries of origin - that is, asylum seekers or persons with refugee status. Yet, the help of kinship networks in the country of origin or of either non-governmental or governmental organizations can be accepted in this case, as the will for foreign credential recognition exists. One interviewee even encountered a problem with the recognition of his diploma obtained in another country of the European Union, which he perceived as a discriminatory practice based on his national origin. 
"Things were very different in the Netherlands. My educational qualifications were regarded as not being at the appropriate level simply because I was Moroccan... and I was told that I would have to start again from the beginning because my academic certificates were not recognized as valid. It was assumed that the academic qualifications of immigrants could not have the validity of the equivalent Dutch qualifications. Even my French diploma was not recognized! This was a great disappointment. I was later able to get a partial accreditation of my qualifications at the University of..., where I was allowed to participate in an academic research project, but was only used for field work. I feel that I am now too old to have much chance of being able to continue my studies. In the Netherlands I worked initially in a leather factory as a manual worker, and then later found work teaching French and Arabic in a private school." [Lahcen, age 4I, Morocco - the Netherlands, then Belgium. Nf: late 1990s]

Besides the negative impact on motivation that may affect the formation of marginalized identity, and difficulties with obtaining work that would be adequate to one's qualifications, the topic of 'brain drain' was brought up by another conversational partner.

"Even my wife, who was a pharmacist in Iraq, has so far only been offered work as a cleaning lady. Lecturing to newcomers or working for a social agency is often the best that we can get. Little wonder then that hardly any of the university educated refugees want to stay in Belgium and that there is a full scale braindrain from Belgium in progress. Only the poorly educated stay as they have no other option open to them." [Khaldoun, age 31, Iraq - Belgium. Nf: 2003]

In the case where 'highly skilled' professionals (particularly researchers) emigrate from the country where they were educated and trained, the destination country receives the human capital as a gift. According to neoclassical economic theory it has made a 'brain gain', whereas the country of origin has suffered a 'brain drain' (Wächter 2006: 53). The approach towards educated immigrants in Europe can in terms of the previous metaphor be described as a lack of interest in a brain gain. Recent research focused on a brain drain from Europe to the U.S.A. does not fully answer the question of how many emigrating professionals come via Europe from Non-EU countries. 
4. Education and learning new cultures. Education does not only fulfil the role of teaching immigrants the language of a host country. Stories and experiences of immigrants indicate the practical importance of courses dealing with the development of social and intercultural communication skills. Learning may become a mutual process, both from the perspective of the 'new' and 'old' Europeans, as well as from that of formal and informal learning. Formal education takes place in a classroom when a teacher provides the necessary knowledge to students a) for the successful completion of the course, and b) for further use in life. And the usability of knowledge and acquired skills is the most important factor for incoming foreigners. The informal side of learning is expressed in communicating with students outside the classroom or lecture hall and is very necessary both in terms of building confidence and also for the process of adaptation and learning a new culture. In some European countries with a rich history of immigration, there are already courses that teach and transfer sociocultural competencies.

Human identity is formed through the reaction and perception of the physical world and through relationships with others, which are mediated by language - the use of language (in terms of discursive practices). "And while the tools with which people produce are the medium through which they gain mastery over nature, so language is the tool and the medium through which people gain influence over the behaviour of others and over their own actions" (Burkitt I991: 139).

"It is important that newcomers learn the language as soon as possible so that they can get started on something and not just sit around at home all day. It is only since I have been able to follow everything which is said on $T V$ and can talk to people that I have come to understand Belgium." [Khaldoun, age 3I, Iraq - Belgium. Nf: 2003]

Nevertheless, the language is not the only thing an immigrant needs in order to adapt to a new culture. If we understand language as a gateway to culture (in the sense of understanding values, norms, symbols and institutions), in particular it functions as the means for the transmission of culture. Usually, the newcomer acquires the rudiments of the new culture informally, which is sometimes insufficient, especially when members of the immigrant community as individuals are socially and spatially separated from the culture of the host country (in refugee centres, ethnic districts). Whoever feels that he/she needs to know more attends courses providing skills and competences for social integration. 
"That was cool! The course was about intercultural competence. There were about is people on the course, some Germans, and people from Turkey, Russia, Senegal, and so on. Everybody talked about his or her experience with other cultures, about confrontation, problems and ways to deal with them. They also put on culturally diverse theatre shows. I liked this course a lot and I had lots of interesting experiences." [Meïssa: age 35?, Senegal - Germany. Nf: 200I]

The actual preparation and teaching of such courses must necessarily be based on "sensitivity" in intercultural communication, since stereotypical ideas are lurking at every step and in the structures of language as well.

"I take a very critical view of the Social Orientation course which I have to teach: even the course itself contains prejudices! I try to put this into perspective for my students. For me the most important element is communication. I find it striking that there is so little contact between newcomers and Belgians: it is exactly the contact that I want to promote, and in so doing to remove the obstacles. Here too I again emphasize the importance of the necessary acceptance on both sides." [Lahcen, age 4I, Morocco - Belgium. Nf: 2003]

Courses alone cannot replace communication between members of different cultures. As the basic deficiency and therefore imperative, a need for informal contacts and for a tendency to value tolerance and solidarity remains.

5. Housing. Private housing is very important because staying in special accommodation facilities (camps, centres) may be stressful. Privacy is highly important in terms of psychological well-being and social significance in many cultures, although ideas about it may vary. Differences in the notion of private space may sometimes lead to misunderstandings. For instance, paying a visit is in some cultures a very common and frequent social practice.

"You may only know the person you are going to visit a little, but there is no need to call in advance, to arrange it. You just come. You cannot say anything to contradict an older person. You have to stand up and remain standing till the guest is seated." [Tumisa, age 43, Chechnya - Lithuania. Nf: 2003]

Noise, crowding and partying during the night probably do not meet with understanding from tenants and apartment owners. But it can often be an 
unwritten (but still significant) social norm tied to hospitality to visitors. The housing sector is also a social field of discrimination in which prejudices against particular groups of immigrants seem to play an important role.

"I've not had any difficulties finding accommodation, for example. But other Africans have had problems. Owners who don't want them, or who impose additional barriers." [Diallo, age 32, Senegal - France. Nf: 1999-2003]

As pointed out by social geographer Ash Amin (2004), some patterns of discrimination from previous migration waves persist and spread to countries with newer migration (housing, labour market, social rights).

6. Interpersonal conflict and the problem of misunderstanding or prejudice. Some people respond negatively to cultural diversity or with a certain degree of distrust, or fear, and these diverse patterns are collectively referred to as xenophobia. The immigrant experience shows that misunderstandings or stereotypes can be overcome through communication, assertiveness and patience, which, however, will not succeed without goodwill on both sides.

The issue of prejudices is more complex than just being reducible to ethnicity it also unfolds along the axes of gender, class and age differences. Besides the phenotypic human characteristics, the recognition process is strongly influenced by the language or its method of use-speech.

"And then there are also some amusing situations. I've an accent, after all. So, at work, when I answer the phone I sometimes get someone saying 'No, I want to speak to the person in charge.' So I have to explain that, in fact, I am the person in charge..." [Diallo, age 32, Senegal - France. Nf: 1999-2003]

The quotation is a good example of the validity of Foucault's concept about the relationship of power and language as discursive practices (Szaló 2003) and Goffman's (2003) concept of stigma. The caller heard Diallo's foreign accent and he took from the stock of his knowledge the stereotypical idea that a foreigner would not be a manager but rather an assistant. Diallo is stigmatized for his French accent. But he is not discouraged by the fact and maintains a positive attitude.

A newcomer is usually expected, given his status as a foreigner, to take a first step. Charity's story shows that the strategy may be successful on the whole. Initial distrust can be broken right at the beginning, but this depends on a particular 
situation, people and conditions in given society. In reacting to various forms of 'othering', an immigrant or an immigrant group "may develop arrangements of voluntary separation and strive for full-fledged recognition by emphasising their social ... inclusion on multicultural grounds" (Szalai 2010: 5), or may be singled out as the consequence of refusal on the part of a major society (e.g. large segments of the Roma community in Central Europe).

"When I moved into the neighbourhood, I visited all the neighbours and introduced myself. I get on well with my neighbours and I have a wide circle of friends, both old and new Swedes. It was not difficult to become integrated into society. Sometimes I may hear someone saying stupid things, but I don't take them seriously, I just consider it narrow-mindedness." [Charity, age 62, Ghana - Sweden. Nf: 1993-2003]

"The management also often pointed me out as a good example for the local factory workers. This, however, caused some of my colleagues to sneer at me. I still remember comments I had to listen to, such as "Let Slanty-eyes do it, he's the best", and the like. On the other hand I remember the positive behaviour of other Czech colleagues, who frequently offered snacks for me to taste, like traditional Czech stuffed cake." Vervang door: [Nguyen, age 40, Vietnam Czech Republic. Nf: late ig8os]

Charity and Nguyen construct in their narratives the positive pole of an immigrant's identity. Charity is not taking everything anyone says very seriously and retains a positive attitude even in the event of some negative reactions from patients or derogatory comments of people in her environment. Nguyen in the same manner managed to integrate himself in spite of the xenophobic and even racist behaviour of some of his co-workers - which was caused by social strains during the economic transformation in the first half of the 1990 - and diminished the cultural differences and peoples' crassness by learning Czech on a professional level (as a translator) via contacts with open-minded locals who became his friends.

Although narratives in the study consisted of stories of good practice as interpreted by successfully integrated immigrants, these people encountered many difficulties and faced many troubles during this long-term process. The interviewees presented several situations in which it had to be very hard not to change course into the direction of a marginalized or a separated identity, and which showed that the disadvantages resulted from "their social position" in the labour market and legal system of host countries rather "than from their 
ethnicity" (Burnett 1998: 14). In this context the term ethnicity implicitly means not only belonging to an ethnic group but also cultural values and norms. While in this part we have approached the immigrant identity in the period before the open formulation of the post-secular thesis (Habermas 2007 in particular), the last part of this chapter deals with changes in the (perception of) immigrant identity that appeared after the realization of the post-secular situation.

\section{Immigrant identities in the post-secular society}

The kind reader who has followed the text to this point may be thinking about why religion was not mentioned in the narratives analysed. The original research design contained the question about religious identity and about the adaptation of religious practices in a host country, but team members from the West European countries considered these questions to be inappropriate, because religion was deemed to be a matter of the private sphere. This brief account from 2003 figures as evidence of the situation before several significant changes during the 2000 s took place.

These changes have roots in the post-1945 development of Europe which needed to be reconstructed after WWII. The states in Western Europe found a solution to the labour force problem that became obvious in later years in the immigration of foreign workers for temporary employment. "By the 1960 s, migrant labour had become a structural feature of Western European labour markets" (Castles 2000: 7). When it became evident that the temporary workers would stay for good, the question of their integration emerged. Among the three main approaches to the incorporation of immigrants, besides assimilation and differential exclusion, multiculturalism (Castles 2002: 1154) was introduced as part of official policy, initially in classical immigrant countries such as Canada (1971) and Australia (1973). West European countries (especially Great Britain, the Netherlands and Sweden), too, began to apply, to varying degrees, multicultural policies in an attempt to integrate immigrants, in particular those of non-European descent (Modood 2007: 4). Multicultural policy has been criticized since the 1970s (Vertovec 2001: 2), with a growing intensity (but also reflexivity) during the 1990s, and was marked as dysfunctional at the beginning of the 2000 s (Alibhai-Brown 200I). Multiculturalism was accused of developing 'a parallel society', i.e. causing the fragmentation of society into a mosaic of mutually (socially) segregated groups/communities. In less than a 
decade multiculturalism was proclaimed dead (by the Bavarian state minister Horst Seehoffer) and the model of the multicultural society branded as a failure (by the German chancellor Angela Merkel and the British prime minister David Cameron) by some high-level European politicians.

Hence, the first change that has a potential influence on the formation of immigrant identity is the shift in de-emphasizing multiculturalism and openly focusing on so-called civic integration. The policy of civic integration imposes the obligation on newcomers to enrol in civic and language courses and to pass the civic integration exam if they want to obtain permanent residence permits or be accepted into the naturalization process. Although multicultural policies were fully abandoned only in the Netherlands, at the same time the civic integration approach (as a political doctrine and social policy) has developed rapidly since the late 1990s (Banting and Kymlicka 2012) and has been "adopted by, among other European states, Finland, Denmark, Austria, Germany and France" (Joppke 2007: 8).

The second process is associated with the changing perception of various religious communities among which co-existence with Muslim communities spurred the most frequent debates. Frédérique Harry (in chapter 8 of this collected volume) shows how the Norwegian far-right movements started to employ religion in their political narratives after Muslims in Europe became the centre of the public debate on integration. These nationalistic movements have in recent decades shifted the emphasis from a secular discourse that had left religion unnoticed, or was opposed to it, to a non-traditional ${ }^{1}$ religious discourse by using the image of Christianity as a symbol for strengthening national identity. Post-secular society witnesses the utilization of the religious facade for the interests of secular movements and institutions. Harry's study contributes to our understanding of the self-perception of Europeans (Norwegians) and empirically confirms that religion has since the late 2000 s become a public and heavily publicized topic.

Riem Spielhaus (2006) presents a similar shift, in the example of Germany, in the perception of immigrants from Muslim countries who have come from different cultures of vast geographical areas. She claims that after decades in which immigrants' religion was rather overlooked, "discussions on Muslims in Germany are now focusing on religious identity" (Spielhaus 2006: 17). In the debates before 2000 , the immigrant issues were discussed in ethnic terms ('the Turks') or within the 'natives vs foreigners' dichotomy, whereas the more contemporary discourse emphasizes their religious affiliation. Allievi (2005) also points out that "the 
immigrant has become the Muslim" and explains that some reasons for this shift are related to recent phenomena such as the increasing number of immigrants of Muslim origin and the emerging role of Islam as a public actor on the global scene. This change in perception brings the problem of homogenizing diverse groups of people with different cultural background and sets of identities that can easily be ostracized and become a political scapegoat. Moreover, the ongoing situation causes a change in the self-perception of settled immigrants, after which the importance of religious identification is steadily growing at the expense of other sources of identity. Roger Brubaker (2013) demonstrates how the relationships between language and religion have changed over the last 20 years. Although language has been both a subject and means of political contestation in the public sphere (and linked to issues of ethnicity and nationalism) and religion has been depoliticized into the realm of private worship, the counter-trend of recent years has led to the deprivatization of religion. Public religion differs from the domain of language in attempting intensively to "authoritatively regulate public and private life" (Brubaker 2013: 16). The study by Cüneyd Dinç (in chapter 2 of this volume), by explaining the importance of the role of religion in the lives of (Muslim) young post-migrants (generations born in immigrant families) in Germany, supports the thesis about gradual deprivatization of religion. All the types of post-migrant devout Muslims bring the question of religious traditions into the public domain with differing intensity as they lead the debate on whether to accept or reject life in German society.

The growth of religious diversity in the Western world can be linked to another significant change that puts into question the thesis about the secularization of modern society (Juergensmeyer 20II). The discourse is personified by one of the leading contemporary thinkers - Jürgen Habermas, who renewed the debate on the post-secular turn. Habermas (2008) assumes that a group of Western affluent societies (besides some European countries, also Canada, Australia and New Zealand), where people's religiosity has decreased in the post-1945 period, are entering a new post-secular age.

According to Habermas, this spatially and temporally limited definition of modern societies as 'post-secular' does not invalidate the secularization theory as it refers to a change in consciousness (Habermas 2008:20, italics in orig.) and further can be linked to the three following phenomena. The first phenomenon is based on an observation that the secularistic belief in the foreseeable disappearance of religion is weakened by global conflicts, while the second process refers to the growing importance of religion within national public spheres. 
The third issue is directly linked to the object of this study because it considers the question of social integration and identities. Habermas (2008: 2I) maintains that 'the issue of tolerant coexistence between different religious communities' is complicated by difficulties in the social integration of immigrants, and concludes that growing social inequality should not be allowed to block the process of integration. Furthermore, he argues that the democratic state should not limit the sources for the shaping of identities by reducing the diversity of voices and opinions within the public discourse.

\section{Conclusion}

The outcomes of Habermas' concept of the post-secular society and the message contained in it confirm the significance of the existing discourse about religious identities and link it directly to the situation in post-immigrant Western countries. The articulation of the post-secular discourse itself has a reflexive effect on society as well as on the scientific community (e.g. how social scientists approach identity at the present time). The consequences of the previously discussed changes i.e. the emphasis on religious identifications - can obscure the understanding of immigrant identity, because widely used sociological categories (in other words, etic terms or a priori frameworks such as ethnicity and religiosity) may lack the explanatory depth and complexity necessary for the understanding or interpretation of what is specific for narratives about immigrants' experiences. Unsuitable frameworks that are also changed from time to time - as we can observe in the case of the post-secular turn - can be counterproductive for understanding the common features of social adaptation and building more symbolic boundaries in the social reality can discourage social integration. Overemphasizing and (over)politicizing one of the sources of identity may cause a bias - as Spielhaus concisely argued in the case of 'non-Christian' immigrants in Germany - that religion is not the only source of Muslim identity and "it is certainly not the only reason for their actions" (Spielhaus 2005: 18). Stefano Allievi (2005) considers this the paradoxical situation in which the integration of Muslims and immigrants in general ${ }^{2}$ gradually continues, while they are still perceived as one of the groups endangering European society. The social identity that is labelled 'immigrant' is constructed by the media and radicalized segments of society as a threat (the Other). ${ }^{3}$ At the same time, autochthonous populations 
strengthen their own reactive identities opposed to the Other within the borders of Europe.

This immigrant social identity does not overlap with the second analytical perspective, i.e. self-identity, which was presented in the middle section of the text, focusing on the narratives of the generally successful (but not nonproblematic) social adaptation ${ }^{4}$ of mostly non-European immigrants. The narrative texts expressed the commonness in the immigrant experience of striving to 'fit in' (to which a negative reaction after a failure to adapt can be a separated identity), the struggle to make a living and uprootedness (marginalized identity) from which identity issues and new identifications seem to stream and which are re/constructed in everyday life via language (Sabatos 2013), thoughts and social practices.5

In spite of all the changes, the question of relevant immigration policies, of balanced conditions in 'the system' and rights for immigrants still remains at the centre of the solution on how to stop the separation and marginalization of immigrant groups - that is, not to let them become minorities but ethnic communities (Castles \& Miller 1993) and individuals with an integrated identity, i.e. people who did not forget their origin and who at the same time feel at home in the new society (Anthias 2002).

\section{Notes}

I The religious discourse may be termed non-traditional, because rather than reviving Christian values, it helps to form a sense of obligation to a national community. Traditional religion (Christianity) is put to the service of civic religion (nationalism).

2 Similarly in the U.S.A., according to Waters and Jiménez (2005), immigrants are being successfully incorporated into American society. (see Waters, M.C. \& Jiménez, T.R. (2005) 'Assessing Immigrant Assimilation: New Empirical and Theoretical Challenges'. Annual Review of Sociology. 31: 105-25.)

3 This definition of social identity follows Szalo's concept (2003), not Erickson's theory of identity construction (Schwartz, Montgomery \& Briones 2006). (see Schwartz, S.J.; Montgomery, M.J. and E. Briones (2006). 'The Role of Identity in Acculturation among Immigrant People: Theoretical Propositions, Empirical Questions, and Applied Recommendations'. Human Development, 49: I-30.)

4 For a similar approach to immigrant identity that is oriented to narratives about experience and in which emic categories are interpreted and translated into etic ones during the analysis see (Maydell-Stevens, Masgoret and Ward 2007). About the analysis of immigrant 
identity focused on a story structure see Benish-Weisman, M. (2009). 'Between Trauma and Redemption: Story Form Differences in Immigrant Narratives of Successful and Non successful Immigration'. Journal of Cross-Cultural Psychology, 40(6): 953-968.

5 Besides anthropology, psychology and sociology, comparative literature appears to be a prolific discipline in publications dealing with identity issues.

\section{References}

Alibhai-Brown, Y. (200I). 'After Multiculturalism,' The Political Quarterly, 72: 47-56.

Allievi, S. (2005). 'How the Immigrant has Become Muslim,' Revue européenne des migrations internationales, $21(2): 135-163$.

Amin, A. (2004). 'Multi-ethnicity and the Idea of Europe', Theory, Culture and Society, 2I(2): I-24.

Anthias, F. (2001). 'New hybridities, old concepts: the limits of 'culture", Ethnic and Racial Studies, 24(4): 619-64I.

Anthias, F. (2002). 'Where do I belong? Narrating collective identity and translocational positionality,' Ethnicities, 2(4): 49I-514.

Banting, K. and W. Kymlicka (20I2). 'Is There Really a Backlash Against Multiculturalism Policies? New Evidence from the Multiculturalism Policy Index, Working Paper 2012:4. Stockholm: Stockholm University Linnaeus Center for Integration Studies.

Berger, P.L. and T. Luckmann (1966). Social construction of reality: A Treatise in the Sociology of Knowledge. New York: Anchor.

Berry, J.W. (1997). 'Immigration, Acculturation, and Adaptation, Applied Psychology: An International Review, 46(I): 5-68.

Brubaker, R. (2013). 'Language, Religion and the Politics of Difference,' Nations and Nationalism, I9(I): I-20.

Burkitt, I. (1991). Social Selves: Theories of the Social Formation of Personality. London: Sage.

Burnett, L. (1998). Issues in immigrant settlement in Australia. Sydney: NCELTR.

Castles, S. (2000). Ethnicity and Globalisation. London: Sage.

Castles, S. (2002). 'Migration and Community Formation under Conditions of Globalization,' International Migration Review, $36(4):$ I143-1168.

Castles, S. and M.J. Miller (1993). The Age of Migration. International Population Movements in the Modern World. London: Macmillan.

De Fina, A. (2000). 'Orientation in immigrant narratives: the role of ethnicity in the identification of characters,' Discourse Studies, 2(2): 131-157.

Goffman, E. (2003). Stigma: Notes on the Management of Spoiled Identity. New York: Simon $\&$ Schuster. 
Habermas, J. (2008). 'Notes on Post-Secular Society', New Perspectives Quarterly, 25 (4): 17-29. Harris, N. (2000). 'Should Europe End Immigration Controls? A Polemic', The European Journal of Development Research, I2(I): 80-106.

Jenkins, R. (2000). 'Categorization: Identity, Social Process and Epistemology', Current Sociology, 48(3): 7-25.

Joppke, C. (2007). 'Immigrants and Civic Integration in Western Europe,' in Banting, K.G. et al. (eds.) Belonging?: Diversity, Recognition and Shared Citizenship in Canada. Montreal: MCGill Queens University Press.

Juergensmeyer, M. (2011). 'Rethinking the Secular and Religious Aspects of Violence,' in Calhoun, C. et al. (eds.) Rethinking Secularism. Oxford \& New York: Oxford University Press, $185-203$.

Kopp, R. (2000). Die Europäische Union auf dem Weg zu einem gemeinsamen Asylrecht. Frankfurt: Pro-Asyl.

Maydell-Stevens, E., Masgoret, A.-M. and T. Ward (2007). 'Problems of psychological and sociocultural adaptation among Russian-speaking immigrants in New Zealand,' Social Policy Journal of New Zealand, 30: 178-198.

Moberg, M., Granhol, K. and P. Nynäs (2012). 'Trajectories of Post-Secular Complexity: An Introduction,' in Nynäs, P., Lassander, M. and T. Utriainen (eds.) Post-secular Society. New Brunswick, NJ: Transaction Publishers.

Modood, T. (2007). Multiculturalism. Cambridge: Polity Press.

Neumayer, E. (2005). Asylum Recognition Rates in Western Europe: Their Determinants, Variation, and Lack of Convergence.

Phinney, J.S., Horenczyk, G., Liebkind, K. and P. Vedder (200I). 'Ethnic Identity, Immigration, and Well-Being: Interactional Perspective,' Journal of Social Issues, 57(3): 493-510.

Ringen, S. (2003). 'Evropa na pokraji úpadku: kam až může vést populační krize' ('Europe on the Brink of Decline: Where its Population Crisis Can Take Us'), Sociologický casopis/ Czech Sociological Review, 39(4): 551-560.

Sabatos, C. (2013). 'Between Two Worlds: Slovak Language and American Identity in Out of This Furnace, Comparative American Studies, II(I): 74-88.

Spielhaus, R. (2006). 'Religion and Identity: How Germany's Foreigners Have Become Muslims,' Internationale Politik: Transatlantic Edition, 8(2): 17-23.

Szalai, J. et al. (2010). Being 'Visibly Different': Experiences of Second-Generation Migrant And Roma Youths At School: A Comparative Study of Communities in Nine Member States of the European Union. Budapest: EDUMIGROM.

Szaló, C. (2003). 'Sociologie formování sociálních identit' ('The Sociology of Social Identity Formation'), in Nosál, I. \& Szaló, C. (eds.) Mozaika v re-konstrukci. Formováni sociálních 
identit v současné stredni Evropè (A Mosaic in Re-construction: Formation of Social Identities in Contemporary Central Europe). Brno: Masaryk University, 13-36.

TEC Project (2004). Life Stories of Immigrants: Guidebook for Trainers, Teachers and Social Workers. Ostrava: Repronis.

Vertovec, S. (200I). 'Transnational Challenges to the 'New' Multiculturalism,.ESRC Transnational Communities Research Programme Working Papers oI-06: I-23.

Vinokurov, A., Birman, D. and E. Trickett (2000). 'Psychological and acculturation correlates of work status among Soviet Jewish refugees in the United States, International Migration Review, 34(2): 538-555.

Wächter, B. (2006). 'Brain Drain: What We Know and What We Don't Know', in Teichler, U. (ed.) The Formative Years of Scholars. London: Portland Press, 5I-66. 

CHAPTER 5

\title{
Manufacturing Self-Respect: Stigma, Pride and Cultural Juggling among Dalit Youth in Spain
}

\author{
Kathryn Lum
}

This chapter, which at first view may be seen as an outlier in this volume, has as its function to broaden our focus on the study of ethnic minority diaspora youth by considering the identity management strategies of a non-Muslim community, the Dalit Indian youth living in Spain. Dalit youth face a dual challenge: how to combat caste stigma and how to negotiate being a racialized ethnic minority in Spain. For former untouchables, intra-ethnic prejudice is just as important as external discrimination. This chapter discusses the importance of music and micro acts of social normalization in defying caste stigma. It then explores the various strategies for integrating a bicultural identity that Dalit Indian youth adopt, focusing on the concept of situational ethnicity. It concludes by considering what this case study of a Dalit Indian community in the diaspora can teach us about segmented integration and bicultural and multicultural identities.

\section{Introduction}

Much of the literature as well as popular discussion on the integration of ethnic minority second generation youth focuses exclusively on the axis of ethnicity or religion. This often ignores cleavages within ethnic groups and gives an impression of ethnic unity and homogeneity that does not exist in practice. In the case of the Indian subcontinent, caste is a significant driver of identity that competes with ethnic/religious identity both in India and the Indian diaspora. 
This is particularly so for Dalit (lower caste) Indians who suffer from intraethnic discrimination from upper-caste groups. In fact, while it is frequently assumed that ethnicity will be the most important axis of identity for Indian ethnic minority youth, the caste stigma that Dalit youth must confront means that caste is at least as important as, if not more so than, their ethnic identities. While all Indian youth in the Spanish diaspora are racialized, this racialization is partially offset by a societal push to recognize and value all cultures equally. In contrast, the issue of caste remains taboo within the Punjabi community in Spain, making caste discrimination a more emotive issue for Dalit youth. This chapter will explore how youth from a 'minority within a minority', belonging to the Punjabi Dalit caste known as the Ravidassia, negotiate caste stigma and ethnic minority status in Barcelona. Grounded in an anthropological methodology, the aim of this research is to ascertain how youth subject to more than one form of discrimination overcome internalized stigma, while at the same time managing dual cultural influences.

The Ravidassia are a group of former untouchables in the regional caste hierarchy of the Punjab, located in Northwestern India, stigmatized by both Hindus and Sikhs ${ }^{\mathrm{I}}$ (although ritual impurity is not important theologically to the latter). The majority of the Ravidassia in the Punjab have adopted a heterodox version of Sikhism that incorporates the worship of their patron saint Ravidass who, despite being untouchable, achieved spiritual renown. Increased education, along with migration overseas, has enabled the Ravidassia community to achieve upward economic mobility in the Punjab, a process which has encountered strong resistance from traditionally dominant caste groups. In Spain, casteism has implanted and reproduced itself, forcing all Ravidassia youth to come to terms with the 'casted mind', despite living miles away from India, where caste politics is a daily reality. Most Ravidassia youth, defined as unmarried individuals under the age of thirty, are of an 'in-between' (Dronkers and van't Hof 1994: 9) or ' 'I.5' generation, due to their status of being Indian born, yet partially raised in Spain: many came to Catalonia at a young age, generally before the age of sixteen. These youth are bilingual and increasingly trilingual: fluent in Punjabi, Spanish and Catalan and familiar with the Catalan school system. Like many other ethnic minority youth, they straddle two worlds - the Punjabi cultural universe of their family and the dominant culture of Catalan and Spanish society. However, as part of a stigmatized caste minority, they must also come to terms with their caste identity in a way that is not required of their upper caste peers. Using the examples of my interviewees, I discuss how Ravidassia youth view the 
caste system and the impact of the new 'Ravidassia pride' movement that has emerged in the wake of the Ravidassia schism with Sikhism in 2009. I will then address how Ravidassia youth negotiate being an ethnic minority in Spain with multiple and often conflicting cultural expectations. I will conclude by analyzing the varied responses of Ravidassia youth to the challenges of biculturalism.

\section{Methodology}

The fieldwork for this chapter was carried out over a period of two years (2009-20II) in the greater Barcelona area and employed an anthropological methodology of ongoing participation observation in the Ravidassia temple and in family homes, as well as repeat, in-depth, semi-structured interviews with young men and women in the 18-30 age group from the Ravidassia community. Interviews were conducted in Spanish and involved the "I.5" generation of young men and women who had migrated with their families to Spain as schoolchildren or early adolescents. Interviews were held either at the university or in a public space such as a quiet café or a park, chosen by the interviewee. The decision to avoid interviews at the temple or in family homes was motivated by a desire for greater privacy and confidentiality. Initial contact with interviewees was made through the temple, as well as via the snowball method, resulting in a core sample of fifteen youth, with a preponderance of young men (II men and four women). This gender imbalance is a result of both the masculine majority of the community and the greater willingness of young men to be interviewed for the study.

\section{Attitudes towards the caste system}

My interviews with upper-caste youth in India revealed that caste was often not particularly relevant for them until they reached university, where the issue of quotas for the lower castes has created a great deal of resentment on the part of upper-caste students. Many affirmed that they normally 'did not think about caste,' a privilege that is not shared by the lower castes, many of whom grow up painfully aware that they are marked out as different and choose to pass when they reach university in order to avoid stigma. In the diaspora, although the vexed issue of educational quotas does not colour caste relations, the caste system is still very much socially present. Eleanor Nesbitt, in her study of perceptions of 
caste among young British Indian youth of Gujarati and Punjabi origin, shows that both Hindu and Sikh youth are well aware of caste. By the ages of eight to thirteen, Sikhs and Hindus are able to identify other children by their caste (Nesbitt 1997: 212). Hindu children understand caste as a hereditary institution and vertically graded hierarchy that implies marriage endogamy. Attitudes to the caste system among non-Dalit Hindus range from their being openly critical to an idealized acceptance (Nesbitt 1997: 207). While the majority accepted intercaste marriage, if somewhat grudgingly, they repeatedly declared that caste was irrelevant when it came to friendship (Nesbitt 1997: 208). Among young Sikhs, both Dalit and non-Dalit, repeated reference was made to 'proper' Sikhs, a concept which was often linked to caste, with Jat Sikhs perceiving themselves as well as being perceived by Ravidassia youth as 'true' Sikhs (Nesbitt 1997 2II-2I2). Among Ravidassia and Valmiki youth (Valmikis are another Dalit group), some youths spoke of their fear of being discriminated against should their untouchable origins be discovered, and of having learned various passing strategies from their parents for dealing with the caste question (Nesbitt 1997: 2I2). Nesbitt concludes that caste and casteism is just as strong among young Punjabi Sikhs as it is among Gujarati Hindus. No longer considered relevant to friendship, it is still seen as central to marriage, although British Indian youth underline the fact that intercaste marriages are increasing (Nesbitt 1997: 213).

Another study, carried out in 200I among predominantly Gujarati Hindu British youth by the Oxford Centre for Hindu Studies (the caste makeup of their sample was unfortunately not indicated), found that $35 \%$ of the respondents affirmed that the caste system influences some of the decisions in their lives, and $43 \%$ agreed with the statement that "the caste system is important to my family" (Santosh \& Vij 2003: 27). In this survey, while caste prejudice was condemned, the positive aspects of caste were also highlighted, such as caste-specific social/ religious events, and the security and identity that caste bestows (Santosh \& Vij 2001: 27). Brahmin youths rejected an ideology of Brahmin supremacy, but some did feel that being part of the Brahmin community made them different and special. Their sample was equally divided on the issue of cross-cultural friendship: $4 \mathrm{I} \%$ preferred to have friends from a similar religious/cultural background, while $4 \mathrm{I} \%$ stated that this was not important. However, with regard to marriage, $67 \%$ declared that it was important for them to have a "Hindu life partner" (Santosh $\&$ Vij 2003: 22-23).

How do Spanish Ravidassia youth ${ }^{2}$ perceive and make sense of the caste system? And how do these perceptions compare with those of other Indian youth in 
Europe? In Spain, I interviewed exclusively Dalit youth regarding their perceptions of the caste system and intercaste mixing. The caste system was universally condemned and frequently compared to racism. Indeed racism as a metaphor was used more often than casteism when describing upper caste discrimination. Ravidassia youth emphasized that upper caste racism was a bigger problem than racism originating from Spanish society. When asked about experiences of racism, very few offered any examples from Spaniards, whether at work or at school. This contrasts with the findings from an Italian case study of second-generation youth from the Maghreb and the Philippines, which revealed local racism, especially in the job market, rather than internal instances of bigotry (Ricucci 2010: 422).

The results from my Spanish interviewees have broadly echoed research already carried out in the UK on youth attitudes towards the caste system. All of my interviewees were in favour of inter-caste friendship, and considered caste to be immaterial in forming friendships. However, their flexible attitude towards friendship contrasted sharply with their views on marriage, where all but one interviewee favoured marrying within one's caste. As in the UK, caste was understood as a hierarchical and hereditary institution, but the legitimacy of this vertical hierarchy, in which Chamars are placed at the bottom, was continually contested. One articulate young man referred to caste as a 'trap', in which all castes, including Chamars, were ensnared: "[e]veryone believes that he is superior to someone else". Thus caste is also understood as a deeply rooted mentality that automatically categorizes and ranks the worth of others - even when the system itself is condemned and despised. The relevance of caste to humanity or to the human personality was consistently challenged. 'We all have the same blood' and 'I am first and foremost a human being' were common refrains. At the same time, Ravidassia youth find themselves operating within a social system in which caste is omnipresent and assumed fundamentally to determine an individual's personality traits. A system which automatically devalues the Chamar/Ravidassia identity and associates it with a number of negative characteristics such as being poor, illiterate, dirty and lazy/unreliable. The dominant caste in Punjabi society, the Jats ${ }^{3}$, were repeatedly criticized for their arrogance and superiority complex. Given that the Jats have traditionally dominated the Ravidassia both economically and culturally, there is a history of conflict between the two communities that has recently been accentuated with the rise of Ravidassia assertion in the Punjab. Many Ravidassia identify the Jats with collective and individual feelings of humiliation and lack of respect. It therefore comes as no surprise that negative stereotypes were voiced about Jats as a group, such as their propensity for drink, 
their lack of education, and their lack of respect for women. Apart from the Jats, only the Lubanas (a generally prosperous intermediary caste) were singled out by the Ravidassia for being particularly casteist. In fact, some of my interviewees pointed out that the Lubanas were sometimes worse than the Jats, but the demographic dominance of the Jats both in the Punjab and the diaspora, means that casteism is most often associated with them. Ravidassia youth therefore find themselves simultaneously dreaming of a world in which caste does not exist and also dealing with the daily reality of caste stigma and the consequences of their low position in the caste hierarchy, which leads them to strike back with negative caste stereotyping of their own.

The supremely important institution of marriage in Indian culture can be regarded as a litmus test of evolving caste attitudes. The strong preference for marrying within one's caste, at all points along the caste continuum, has made marriage the preeminent institution for maintaining caste boundaries. The modern leader of India's Dalit movement, B. R. Ambedkar, recognized this and preached that ultimately only intercaste marriage could undo the caste system. Surveys of Indian youth show, despite expectations to the contrary, that they are surprisingly conservative with regard to the issue of marriage. A survey conducted by the national magazine India Today, for example, found that $73 \%$ of youth believe in arranged marriage (Bobb: 2006). This trend is echoed in the Spanish diaspora. The majority of Ravidassia youth accept the institution of arranged marriage (or at least the utility and ease of an arranged marriage), and prefer to marry a girl or boy of their own caste. As in India, the main reasons offered are the 'better understanding' within the same caste or $j a t$, and the greater parental and community support that intracaste marriages enjoy. No one wished to marry a Spaniard; the strong preference was that their marriage partner should be Indian, preferably an Indian settled in Spain. In preferring to marry a fellow Chamar, youths frequently pointed out that mixed marriage (both out of caste and with Spaniards) was disapproved of by the community - particularly so on the part of girls. Indeed, one girl pointed out the dramatic gendered double standard regarding marrying out: "[i]f I marry a Spanish boy, it is horrible; it will be very badly seen. If a boy does it, it is normal, people will feel proud, that he has married a gori (a white girl)'. Intercaste marriages were primarily viewed as undesirable due to cultural differences - a theme also echoed repeatedly in India. 2I-year-old Balminder spoke for many when he highlighted the cultural differences between Chamars and other jats and emphasized the problematic nature of marrying out of caste: 
"Normally Chamars don't marry with people from other castes. The Jats are not raised well. They drink a lot of alcohol, they do drugs, they have a lot of vices...people with problems. Not all are like that, but the majority yes. We prefer with another Chamar. They will be of the same culture, they will think in the same way, they will understand each other better... it will avoid problems." (Balminder, male, 21 years, Barcelona)

The key difference in the relationship to the caste system experienced by the upper castes and Dalits is that while caste is particularly salient when it comes to marriage and community events for all caste groups, it does not pose the problem of stigma management that the lower castes face. Upper caste youth do not have to think about how a new acquaintance will react to their caste identity, whereas the lower castes are aware that they are potentially 'discreditable' at any time. In addition, while marrying within one's caste is accepted across a wide spectrum of youth, the motives for doing so can be quite different for Dalits, who often fear that they will never be truly accepted by their in-laws if they marry out of caste.

\section{"Putt Chamara De"- The Emergence of a Chamar Pride Movement}

The term 'Chamar' in India is a highly stigmatized one, equivalent to the highly derogatory term used to humiliate African Americans. Under the SC/ST (Scheduled Caste/Scheduled Tribe) ${ }^{4}$ Prevention of Atrocities Act of 1989, it is a legal offence to call someone a Chamar. However, in the wake of the attacks on the spiritual leaders of Dera SachKhand Balland (the leading religious centre of the global Ravidassia community), which resulted in serious injury to their most senior leader and the death of his much respected second-in-command, the term Chamar has since been reclaimed by the community. The attacks on their beloved leaders (the personal gurus for a number of Ravidassia both in India and the diaspora) led to immediate riots in the Punjab. However, more than three years after this tragic incident, which took place in Vienna in 2009 during a European tour by the gurus, the most visible change has been cultural. Starting in 2009, there was an explosion in songs that, imitating the pre-existing trend to exalt 'Jatness' in Punjabi folk music, sing the praises of the Chamar caste. Diaspora Ravidassia have played a key role in funding and promoting this musical renaissance (Dogra: 20II). Although the first such song "Putt Chamara 
$D e$ " (Sons of Chamars) appeared in 1998 , in the aftermath of the Vienna attacks, a veritable tide of songs has flooded the market, all with themes that speak of pride in being Chamar. Examples of songs include titles such as 'The Fighter Chamar,' 'Hummer Chamar', 'These self-respecting Sons of Chamars', 'Think before Messing with a Chamar' and 'Young Lions of Chamars.' These songs have all been accompanied by videos that have been hugely successful among the Ravidassia community.

For the first time, Ravidassia youth are able to listen to songs that speak to their need to assert themselves culturally and claim collective self-respect, in a broader context in which they feel their identity is under attack. They are reclaiming bhangra, as Punjabi folk music is known, as a musical genre for their community after a long history of its being intimately associated with the Jat caste. Ethnographic studies of the Jat community show that bhangra is identified and claimed by Jats as being 'their music' (Mooney 2008: II3). Ravidassia youth use social media such as YouTube to listen to and share videos of their favourite songs. In the gurudwara, 'have you heard the latest song?' has become a common theme of conversation, and youths proudly discuss the number of songs now available. During the 2010 birthday celebration for Guru Ravidass in Barcelona, one of the most popular "Putt Chamara De" songs was sung during the religious ceremony, indicating how symbolically important such songs have become. It is important to point out however that it is predominantly male youth who are the most enthusiastic fans of these songs. The videos that accompany them show young, well-built, menacing Ravidassia men who often brandish swords or guns, in a clear message that Ravidassia men will no longer be bullied or made to feel inferior by upper caste men. Their common theme is 'we are just as manly as you'. Most of the titles make reference to Ravidassia boys and men only, such as the song 'I've heard that there is talk of Chamar boys everywhere'. As with 'Jat pride' songs, 'Chamar pride' songs are aimed at promoting a specifically male Chamar pride and bolstering Chamar masculinity. Thus far, no song addressing Chamaris (female Chamars) has been released. However, one of the most popular singers in the Chamar pride movement is a young Punjabi woman known as Miss Pooja, who has galvanized the collective consciousness of the Ravidassia Chamar community with her inspiring song "Begumpura Vasauna" ('Establish Begumpura', the paradise of social equality envisaged by Ravidass).

For youth raised on a constant diet of 'Jat pride' bhangra music, a cultural phenomenon which many previously took for granted, the new songs that speak positively of Chamars have greatly stimulated pride in their caste. Prior to the 
Vienna attacks, some Ravidassia youth rued the fact that many famous singers were Chamars, but due to caste stigma were not open about their caste identity or, even worse, sang 'Jat pride' lyrics. Now Ravidassia youth were eager to list all the singers who were Chamar, and more importantly, singing Chamar lyrics. The psychological impact of these songs on the self-esteem of a group that has historically been both underrepresented and negatively portrayed in popular culture should not be underestimated. In the words of a seventeen-year-old computer science student enrolled in a professional training college, these songs represent a collective 'awakening' of the Ravidassia:

"I feel good when I listen to these songs. I feel a lot of pride - before also, but now more. Now we are more awakened. I listen to loads of songs every day; this music is ours, it makes me feel strong. I no longer listen to the songs of Jats...they speak about Punjabi culture like it was theirs, as if all important persons were Jat. These songs for the low castes are good to wake up our people. Now, there is more pride, I say, 'what's up Chamar' jokingly to my brother." (Nandeep, male, 17 , Barcelona)

Although songs form the backbone of the emerging Chamar Pride movement, at the individual level important transformations are also taking place that have the potential to completely revolutionize the unequal power dynamics that structure social interactions between former untouchables and the upper castes. A growing number of Ravidassia youth, both male and female, are becoming micro ambassadors for Chamar pride in their daily lives through attempts to normalize their caste identity - that is, by declaring their caste identity as nonchalantly as their upper caste counterparts do. Just as Chamar Pride songs seek to make the Chamar caste like any other, declaring their caste identity with inner pride and confidence seeks the same in daily social life. For such normalization to take place, Ravidassia youth must first begin the process of 'de-Othering' themselves in their own minds, which enables them to embrace their stigmatized identity and feel comfortable with it despite its social devaluation. It is a process of defying stigma from within and coming to terms with stigma in such a way that it no longer provokes anxiety or feelings of inferiority. Goffman speaks of the 'moral careers' of stigmatized individuals, to describe the learning and socialization experiences of those who share a particular stigma. As in his definitions of discredited (visible) stigma versus discreditable (invisible) stigma, he is careful to distinguish between different types of 'moral careers', depending 
upon the stigma in question. He also identifies two phases of socialization: that in which the individual acquires and internalizes the standards/norms of dominant society, and that in which he or she learns that he has a stigma, and the consequences of possessing it. Goffman calls the moment of stigma realization a 'moral experience' (Goffman 1963: 33). Most Ravidassia youth confessed that their strongest moment of stigma realization came when they moved to Spain and faced both subtle and open prejudice in Barcelona's guruduwaras. What Ravidassia youth are currently attempting is a brave new moment in their 'moral careers': that of stigma unlearning.

An example is offered by 24-year-old Surinder, a pharmacy student who also works part-time in a local health centre. Gone is the discomfort and unease that she used to feel when faced with the ubiquitous caste question. Reflecting on how she now feels internally when someone asks her about her caste, pharmacy student Surinder offered the following observations:

"I don't like to say that I am from a low caste, but rather that I have this caste, and that's it. If I ask someone from an upper caste about their caste, they feel proud, they feel good that you have asked them that question, so why should I feel bothered or angry because I am asked?...For a Chamar or a Chuhra on the other hand, they always reduce themselves and this should not happen. I think that in a situation in which the person before you thinks he is strong because of his caste, I think a low caste person has to be his equal... Now if someone asks for my caste it's as if they are asking me for my name and that's how I respond, I am proud to be Chamar." (Surinder, female, 24 years, Barcelona)

After several years of internal struggle, Surinder reached the conclusion that the only feasible alternative was to accept and value oneself fully:

"If I don't accept myself, what other options do I have?....None, and they are all negative. And they will affect you more. And what's more, you will suffer...you have to come to the realisation that you must accept yourself in your entirety. Otherwise you will always be on the defensive." (Surinder)

Surinder's path to self-acceptance came through the realization that she could claim a piece of upper caste privilege and enjoy the same social ease that they do by fully accepting her difference and considering herself entitled to the normality 
that is usually the prerogative of the upper castes in social life. For Ravidassia youth in the Spanish diaspora, then, Chamar pride, both in songs, and internally, is transforming their self-image and giving birth to a new self-confidence and nascent assertiveness. In effect, Ravidassia youth, through music and in everyday social interaction, are creating a new language for thinking and feeling about their caste that is reclaiming the traditionally demeaning term of 'Chamar' and turning it into a term of self-respect, akin to 'Jat' or 'Brahmin'. The Chamar pride movement shows that stigma, no matter how deeply rooted, can be overcome, at least from below, from those who suffer from its psychological weight. It also reveals that popular culture, in this case music, can be a very effective tool for 'speaking back' to dominant groups and creating a self-affirming alternative narrative to that offered by mainstream Punjabi culture.

\section{Situational biculturalism}

In addition to overcoming caste stigma, Ravidassia youth living in Spain face a number of challenges related to their cultural identity. Whilst Spanish youth also deal with identity issues and must work out 'who they are', they do so supported by the majority culture. Native youth in Catalonia are more likely to report a Catalan/Spanish dualism, a cultural frame that is largely absent for Ravidassia youth, for whom the Spanish/Catalan binary is less emotionally salient than the India/Spain binary. Similarly, Ravidassia parents have the anchor of Punjabi culture to help them weather the stormy seas of adapting to a new culture, language and way of life. Ravidassia youth, on the other hand, must negotiate two different, and often diametrically opposed, sets of cultural values. They find themselves inhabiting a psychological 'borderland', much like the Mestizo community in the United States described by Anzaldúa (Anzaldúa: 1987). They receive contradictory messages regarding how to behave and identify - one at home and within the community, and the other, at school and in broader society. How do they resolve the psychological conflicts resulting from having dual cultural influences? Some theorists, such as Phinney (1999), posit a developmental model of ethnic minority identity that sees ethnic minorities proceeding neatly from one stage to another. He identified five stages: I) conformity, characterized by a preference for the dominant culture; 2) dissonance, characterized by conflict between the dominant culture and the culture of origin; 3) resistance and immersion, characterized by rejection of the dominant culture and acceptance 
of the culture of origin; 4) introspection, during which the previous trend is intensified; and finally s) integration, characterized by a synergy between the two cultures. I believe that this developmental model is of limited use in helping us to understand the complex process of identity development among ethnic minority youth. In practice, individuals do not proceed in a linear fashion from one stage to another, but rather may be juggling several stages at the same time, depending upon the issue in question. My research reveals that ethnic identity for Ravidassia youth is very much situational in nature and is much more fluid than Phinney's model allows for.

Marcia (1980), who identified four statuses of ethnic minority identity, offers a more flexible, non-developmental model: r) identity achievement, in which an identity is committed to after a period of exploration; 2) foreclosure, in which an identity is chosen without personal exploration, following family and community prescriptions; 3 ) moratorium, during which one is in the process of exploration; and 4) diffusion, in which no effort is made to explore or make an identity commitment. While Marcia's model is an improvement on Phinney's, it speaks of identity commitment in monocultural, as opposed to bicultural terms - it does not appear to allow for a dual identity commitment. It shares the limitation of Phinney's model in that it does not contemplate the possibility that all four stages may be present simultaneously depending upon the identity issue that a particular youth may be facing. Like the previous model, Marcia's model is too static and fails to capture the complexity and constantly changing nature of ethnic minority identity dilemmas. I argue that the fourth stage of diffusion is more likely to apply to majority than to ethnic minority youth, since most ethnic minority youths are forced to reflect upon the nature of their ethnic identity and to make certain choices in order to be accepted both within their community and within the majority culture. Usually, it is only dominant culture youth who have the luxury of being non-reflexive and non-explorative, since they take their cultural references and values for granted and do not feel the need to interrogate them.

I find the model proposed by Berger, who studied the coping strategies of Jewish adolescent immigrants from the former Soviet Union in New York, to be more useful in helping us to understand how adolescent immigrants make sense of their dual identities. Berger (1997) identified four patterns for dealing with what she calls adolescent immigrants' 'double identity crisis': I) clingers: those who hold on to their native culture and either passively or actively refuse to adopt the host culture; 2) eradicators: those who erase their culture of origin 
and wholeheartedly embrace the norms of the new culture; 3 ) vacillators: those who oscillate between both cultures, finding it difficult to choose either one; and 4) integrators: those who concurrently balance aspects of both cultures, defined by Berger as truly bicultural (Berger 1997: 268.268). Berger points out that both individual factors, such as the perception of the place of their culture within the majority culture, and social factors, such as family dynamics, impact upon the coping patterns of ethnic minority youth (Berger 1997: 266). I would also add the critical factor of gender, since female Ravidassia youth have less scope for identity exploration than their male counterparts due to the patriarchal gender norms that govern Punjabi culture, leading to greater restrictions on their mobility and free time (most girls are expected to come home directly after school or work). The reputation of girls is much more fragile and Ravidassia girls are thus less able to take risks when managing their dual identities.

My research among Ravidassia youth living in Spain reveals that Ravidassia adolescents exhibit aspects of all four patterns outlined by Berger, although with very few eradicators, since the vast majority of Ravidassia youth are proud of their Punjabi/Indian heritage and value their culture. Ricucci, in her case study of North African and Filipino adolescents in Italy, also found that it was 'very important' for them to maintain their culture and language (Ricucci 2010: 422). Strong social and family control also means that most Ravidassia youth are not free to eradicate, even if they wished to do so. Thus, rather than represent only one of the patterns defined by Berger across the board, Ravidassia youth tend to adopt different identity strategies and levels of Spanish/Indian identification depending upon their physical environment and the situation in which they find themselves - performing a situational ethnicity. In the gurudwara, at home and in the street (particularly in areas with a large Indian/Pakistani population), they will enact a Punjabi ethnic identity (for example, through dress in the gurudwara and by taking care not to be seen speaking with someone of the opposite sex in public). At school, work or with non-Punjabi friends they will enact more syncretic ethnic identities. They live in two different cultural worlds, which they are adept at managing and keeping separate when necessary, performing a variety of ethnic identities simultaneously. Okamura, in his study of situational ethnicity, defines it as the ability of 'actors' either to affirm or obscure their ethnic identities in specific situations, ideally to their advantage, but with the caveat that such choices are always circumscribed by the overall structure of ethnic relations (Okamura 198r: 454-455). In recognizing the fluid and at times strategic nature of ethnic identity, we avoid the reification trap, and also capture 
the fundamental contradictions inherent in all identities: just as women may strategically emphasize or downplay their 'femininity' in the workplace, ethnic minorities also adopt social situation-specific strategies for managing ethnicity.

\section{Cultural jugglers}

2I-year-old Balminder, a mechanical engineering trainee, is a good example of this cultural juggling and individual mixing of the four patterns described by Berger. Balminder is a leading member of the community due to his language skills and is very active in the gurudwara. He is a confident integrator, who at times also demonstrates aspects of clinging and eradication, depending upon the cultural conflict with which he is faced. He describes Ravidassia youth as "iguanas", skilled at changing their self-presentation depending upon whether they are at home, at school, in the street or in the gurudwara. He himself affirms that he feels completely bicultural, adopting 'half of Indian culture and half of Spanish culture'. However, there are times when the collision between the two is so great that he feels 'radical, extremist' and chooses either Indian culture or Spanish culture in order to resolve the conflict. A dramatic example of eradication is when he and his younger brother took the momentous decision to move out of the family home despite being quite young and unmarried, a taboo even for boys in Punjabi culture (and completely unthinkable for girls). In taking this decision, he challenged not only the sacrosanct authority of his aunt and uncle, but also the injunction of his culture against youth independence prior to marriage. In putting his individual wishes ahead of those of his family, he was able to draw upon Spanish culture in order to support his case and validate his decision, although he confessed that he continued to feel guilty for several months after the move.

In contrast, in an example of "clinging", Balminder refers to his personal discomfort about showing physical affection in public. Whilst asserting that seeing other Indian or Pakistani boys kissing their girlfriends in public did not bother him, he declared that he personally would never dare to do so. Some things, he said, 'just don't change, no matter how long one has lived in Spain'. Interestingly, for both Balminder and other Ravidassia boys it is often round issues of gender values and behaviour that culture conflict arises. A number of boys mentioned the dress of Spanish women or customs such as kissing in public as examples of cultural clashes that provoke unease - clashes that are usually 
resolved in favour of Punjabi gender norms in one's personal life. Balminder offered an example of when his two cultural worlds collided simultaneously, and he was confronted with the difficult situation of having to balance both at the same time. He related how once when he was walking with his aunt in the street, he met a former Latin American classmate who gave him an enthusiastic traditional kiss, as they had not seen each other for some time. He went bright red, and felt deeply embarrassed at his (shocked) aunt having witnessed such an intimate display with a classmate of the opposite sex. At the time he felt acutely uncomfortable, since he could not enact his usual environment-specific identity strategies. Later, however, he questioned why he should have felt so embarrassed, showing that the question of ethnic identity for Ravidassia youth is continually in flux.

Ravidassia girls face the same identity dilemmas as their male peers, but have less freedom when it comes to cultural juggling and balancing. Girls, as the repositories of both community and family $i z z$ at or honour, must jealously guard their reputations. This means that they are more limited in the extent to which they can be culturally syncretic. The findings of Remennick, however, show that without such restrictions, it might well be young Indian women who sought to balance the two cultures more. Remenick studied the integration processes of the I.5 generation of Russian immigrants in Israel, and discovered that young women were more open to social adaptation, learning Hebrew and forming friendships with other Israelis, than their male peers, who showed greater cultural conservatism (Remennick 2003: 59).

24-year-old Surinder is an excellent example of an integrator. She is fluent in both Punjabi and Spanish/Catalan, has a number of Spanish acquaintances and incorporates aspects of both Indian and Spanish culture in her daily life. She both works and studies pharmacy, and is determined to be financially independent. Yet, as a girl, she has faced additional hurdles in carving out her dual identity. In secondary school, she fought a major battle with her parents, particularly her father, for the right to wear jeans. Her parents had initially forced her to wear traditional Punjabi dress at all times, and it was only with much debate and discussion that she managed to secure the right to wear jeans. She is currently resisting their persistent attempts to marry her off, for she is nearing the age at which Punjabi girls' value on the marriage market begins to 'expire'. Thus far, she has managed to delay marriage with her studies and her insistence on first establishing herself professionally. Many of the freedoms that Spanish girls take for granted, such as the right to go the beach, go out at night or have male friends, 
are denied to Surinder and other Ravidassia girls. Her desire to balance Spanish and Indian culture in her life is often frustrated by unspoken gender norms that proscribe certain activities for girls. For example, although Surinder would like to distribute langar (vegetarian food served at the end of religious services) in the gurudwara, she does not dare attempt to, fearing the reactions of her community. In the Ravidassia gurudwara, langar distribution is a task that has been monopolized by boys and men, based on the assumption that it would not be appropriate for girls to come into 'close' contact with males via serving food.

Therefore, Ravidassia girls, in addition to juggling the norms and expectations of two very different cultures, must also operate within a restrictive gender ideology which, while also affecting boys, is far more punishing for and effective at policing girls. Surinder feels bicultural, but affirms that it 'depends on the situation', once again revealing the importance of situational ethnicity. Surinder also experiences significant vacillation as she struggles to integrate the two cultures. She declares that she feels as if there were 'two Surinders', and confesses that committing to one is difficult. She describes how the opinions of each culture are so different that she does not see how she can reconcile them at times. For Ravidassia girls, the challenge of cultural reconciliation can be greater due to the expectation that they will remain faithful to Indian gender norms. Since the Punjabi community in the Spanish diaspora has effectively used gender norms as a cultural boundary marker, cultural and gender boundaries are often coterminous. Thus the way 'their' women and 'our' women dress and behave is used to distinguish the culture of origin from the majority culture, and also to value the culture of origin positively as morally superior. This makes girls' juggling acts all the more difficult, since transgressing a cultural boundary automatically implies transgressing a gender boundary as well, all too easily bringing with it the accusation of being 'bad girls'.

\section{Biculturalism strategies}

Ravidassia youth tend to respond in one of three ways to the challenges of biculturalism: they become positive jugglers, anxious jugglers or comfort zone jugglers. Regardless of the shifting intensity of their ethnic identification(s), or whether they have achieved the position of integrator defined by Berger, all must to some extent balance the demands of living in two different cultures. Positive jugglers are those who see the benefits of biculturalism in their 
lives, despite its stresses and difficulties. An example of a positive juggler is Balminder. He consistently highlights the positive aspects of biculturalism, despite acknowledging its inherent difficulties, as well as the problems that come from having to deal with families that are not 'modern' and gossipy members of the community that make it their business to keep an eye on the youth. Balminder defines having two cultures as 'fun', pointing out that he has twice the options when it comes to entertaining himself: he can choose both Spanish and Bollywood films. He emphasizes the advantages of being able to choose the best of both cultures, the superior linguistic capital that having two cultures provides, a wider friendship network and the ability to connect with a wider range of people due to greater cultural knowledge. In other words, he feels that being bicultural has significantly enhanced his cultural, social and linguistic capital. Indeed, he believes that his biculturalism will also bring him practical benefits in the job market. 22-year-old Akalpreet, who has completed her studies and now works in a fast food restaurant, echoes Balminder's sentiments when she underlines that she has been able to learn many things thanks to her biculturalism, and above all, enjoy greater liberty as a girl than would have been possible in the Punjab.

However, there are those for whom the stress of constantly having two cultural options and messages becomes overwhelming, resulting in biculturalism being viewed through a negative as opposed to a positive prism. These youths find that the inner turmoil of cultural juggling outweighs its possible benefits. They are self-reflexive, and hence are aware of the psychological effects of biculturalism in their lives. This is particularly the case for female youth, who are subject to a multiplicity of gender pressures.

Surinder is a good example of how double standards for sons and daughters in the diaspora create additional anxiety for young women. Surinder states that, until now, having to juggle two cultures has made her depressed, and refers to the juggling as a constant struggle that causes stress and anxiety. While she hopes that in the long term at the age of forty or fifty she can say that being bicultural has benefited her, she currently feels overwhelmed by having to deal with diametrically opposed values on a daily basis, particularly in the field of gender. She gives the example of make-up to illustrate her case. In the Punjab, unmarried girls generally do not wear make-up, but after marriage they are socially expected to apply make-up in order to advertize their married status publicly. In Spain, by contrast, girls generally start wearing make-up at an early age, but are not expected to follow a particular make-up protocol after marriage. Surinder cited this example as just one of many 
with which she is faced (should she wear make-up to the gurudwara?) and finds difficult to resolve satisfactorily, leading to chronic anxiety. Another thorny area was marriage:

"My parents want to marry me with someone with a high level of studies - he should be from my caste. I don't care about his level of studies or his colour (skin tone). My goal is not to marry someone from my caste - it is my struggle. Every time we go to India they want to marry me. All my female cousins were married at the age of eighteen - for them I am old! My argument is this: I want to be independent and provide for myself... It is already difficult to decide with whom you want to marry. Imagine with a person from another caste. It is difficult, but not impossible. It is the young generation that has to change. I think that if we young people give a good example to children, those children will have an easier time when they become youth." (Surinder, female, 24 years, Barcelona)

Surinder was one of the few youths who spoke candidly of the conflict between following one's heart and obeying one's parents and conforming to broader community pressure:

" $[\mathrm{t}]$ he izzat, the dignity of my parents, their image in the community is important. The decision depends upon them. What do I want? That they decide for me? I could not be happy if I obey my parents, I would be killing all my dreams, what I want...what is more important: happiness or dignity?" (Surinder, female, 24 years, Barcelona)

Surinder is not alone in experiencing an intense internal struggle to reconcile conflicting desires - following her own heart and pleasing her parents. Her dilemma has been studied in the psychological literature on second generation diaspora youth. Srinivasan, in her comparative study of Indian origin female university students in the US and India, found that psychological stress was highest among Indian females and Americans of Indian origin who most identified with Indian culture. Indian American and Indian females reported high stress levels (much higher than their European American counterparts), due to marriage/career pressure and a psychological discrepancy between their publicly stated values and their 'inner' attitudes (Srinivasan 2000: 148-49). 
The strong pressure to be 'good Indian girls' to which they are subject gives them a much heavier psychological burden.

A third trend is represented by comfort zone jugglers, who are less self-reflexive than the previous two groups. Their response to the stress inherent in combining the two cultures and defining their ethnic identity is to remain within a Punjabi cultural 'comfort zone', effectively avoiding the often intense inner conflict experienced by anxious jugglers. Such youths frequently deny the presence of cultural stress in their lives and maintain that they have no problems with Spanish culture. 17-year-old Nandeep is an example of a comfort zone juggler. Apart from one Pakistani classmate who is an acquaintance, all his friends are Ravidassia. He goes to the gurudwara every Sunday, and his cultural references are predominantly Punjabi. He watches Indian films, listens to Punjabi music and eats exclusively Indian food. While comfort zone jugglers do not actively reject Spanish culture, psychologically they distance themselves from it and are often critical, especially of its gender norms. Nandeep, for example, while claiming that everyone is free to do as he or she pleases, speaks critically of Spanish woman bathing 'naked' at the beach or being scantily dressed. They exhibit more neutral attitudes towards biculturalism, precisely because they seek to avoid the sort of questioning - and the inner doubt/uncertainty - characteristic of Ravidassia youth who confront the challenges of biculturalism head-on. Thus while almost all Ravidassia youth affirm that they incorporate aspects of both Indian and Spanish culture into their lives and feel 'both from here and from India', their responses to the difficulties involved in cultural juggling vary.

\section{Conclusion}

For Indian diaspora youth from Dalit castes, striving to achieve self-acceptance and overcome caste stigma goes hand-in-hand with cultural juggling. They face not only the social and psychological challenges of biculturalism, but also, unbeknown to the host society, internal prejudice and discrimination. Their experiences show that an exclusive focus on ethnicity alone as an axis of integration is mistaken: the internal cleavages of immigrant communities must always be taken into account, particularly in policy-making. The situational ethnicity approach of Ravidassia youth reveals that although Indians are always racialized in the diaspora, they can affirm their ethnic identities in ethnicmajority spaces, and enact a variety of social performances in majority spaces, 
which can vary from emphasizing a Spanish identity to combining both Indian and Spanish identifications depending upon the situation. This gives flexibility but also gives rise to identity management strategies. Broadly, whether positive, anxious or comfort-zone jugglers, the integration process of the 1.5 generation of Ravidassia youth in the Spanish diaspora can be described as segmented, in which most youth are 'Punjabi' at home but 'Spanish' to varying degrees in public life. Srinivasan describes the first generation of Indian immigrants to the US as 'dichotomizing' their lives between the family and the outside world, while the I.5 second generation and second generations consider the US their home (Srinivasan 2000: 138). However, this case study has shown that segmented integration and compartamentalization also occurs in the 1.5 and subsequent generations, which can in part be attributed to the different sociocultural contexts of Spain and the US: the former is a relatively new immigrant country and continues to maintain a citizenship policy based on ius sanguinis. My findings coincide with those of Remennick, who also found that the 1.5 generation of Russian immigrants in Israel remained firmly connected to their co-ethnic circle in the private realm, for friendships, a social safety net and intimate relationships (Remennick 2003: 60). Rather than interpret these findings as an indication that the Ravidassia community is not integrating as desired into Spanish society, I would argue that segmented integration need not be viewed as 'holding immigrants back'. Success in education and employment can co-exist with social networks that are principally co-ethnic. Indeed, despite not being established for very long in Spain, some members of the 1.5 generation have started to enter university, while others are setting up their own businesses.

Paul Scheffer, in his book "The Open Society and Its Immigrants", argues that migration entails a shared experience of loss and alienation on the part of migrants and of natives, since both lose familiar worlds and must come to terms with a new reality. According to Scheffer, this mutual loss is akin to the process of grieving, in which there is initially resistance to and denial of loss, followed by anger and finally acceptance (Scheffer 2010: 17). He also stresses the difficulty that particularly the in-between generation faces in finding a sense of belonging, rootedness and 'home'. However, in emphasizing a discourse of loss, Scheffer ignores both the tangible and intangible gains that the in-between generation reaps, despite the stress of cultural juggling. While it is true that, as Scheffer puts it, 'it takes a great deal of effort to balance on a slack rope slung between the country of origin and the country of arrival', cultural juggling also produces cultural richness and resilience (Scheffer 20IO: 3I). I argue that we need to adopt 
a new paradigm for viewing integration and migration, one in which having multiple identities is increasingly normalized for all citizens, both native and migrant, rather than viewed as problematic or as an obstacle to integration. The 'imagined community' of all citizens needs to be expanded in order to make room for multiple identifications and affiliations. While we speak about a 'globalized world', the reality is that nations, like religions, are keen to stake out exclusive psychological territory, as witnessed by many nations' unwillingness to recognize dual nationality. Similarly, at the social level, the ubiquitous question of 'where are you from?' that the in-between generation faces reveals that at the micro level we continue mentally to perceive and classify individuals according to their ethnicity, implicitly making those of the in-between and subsequent generations feel out of place in their own country. While the results of my research show that cultural juggling can be unsettling and anxiety-provoking, it ultimately serves as a creative source of social and emotional capital that will hopefully lead to more open, tolerant and creative citizens in the long term. Whether positive, anxious or comfort zone jugglers, all Ravidassia youth are active in carving out a cultural path for themselves in which they can claim pride in their various identities. They are true 'cultural workers' in a world that still privileges monoculturalism. This case study of Ravidassia youth living in Spain shows that the future of a strong Europe will be one in which all citizens move away from monoculturalism, which can be viewed as a form of cultural deficit, and adopt what one international movement of highly mobile individuals calls the 'third culture', to characterize their plural cultural and psychological identifications. Bi- and multiculturalism at the individual level should no longer be exclusively identified with migrants and their offspring, but rather as a resource for all citizens.

\section{Notes}

I Sikhism is a religion that was born in 1469 , founded by Guru Nanak in the Punjab. Although influenced by certain aspects of Hindu culture, its ten Gurus condemned the caste system, purdah (the segregation of women) and ritualism, all common features of Hindu society at the time.

2 Throughout this article I employ Indian English usage when referring to unmarried youth: boy for unmarried young man and girl for unmarried young woman. 
3 The Indian caste system is extraordinarily complex, with different regional manifestations of caste that do not always place the Brahmins at the pinnacle of the local hierarchy, but rather regional castes whose power often derives from their ownership of land.

4 Scheduled Caste and Scheduled Tribe are official Indian government terms used to refer to the former untouchables in the case of the scheduled castes and to various tribal communities in the case of scheduled tribes.

\section{References}

Anzaldúa, G. (1987). Borderlands/La Frontera: The New Mestiza. San Francisco: Aunt Lute Books.

Bobb, D. (2006). Best of Both Worlds: Young Indians want managed modernity and tradition with a twist: survey. India Today. Available at: http://indiatoday.intoday.in/story/young -indians-want-managed-modernity-and-tradition-with-a-twist-survey/I/181872.html. Accessed on February $5^{\text {th }}$, 2012.

Berger, Roni. (1997). Adolescent Immigrants in Search of Identity: Clingers, Eradicators, Vacillators and Integrators. Child and Adolescent Social Work Journal, I4 (4): 263-275.

Dogra, C.S. (2011). The First Law: Sing My Name. Outlook India. Available at: http://www. outlookindia.com/article.aspx ?277445. Accessed on February $5^{\text {th }}, 2012$.

Dronkers, Jaap and Van't Hof, Louise. (1994). 'Differences in Educational Attainment of Children from Various Groups of Recent Immigrants in the Netherlands: Class, Family or Migrant Culture?', Migration, 26:5-49.

Goffman, E. (1963). Stigma: Notes on the Management of a Spoiled Identity. New York: Simon \& Schuster.

Marcia, J.E. (1980). 'Identity in adolescence,' in J. Adelson, ed. Handbook of adolescent psychology. New York: John Wiley.

Mooney, N. (2008). 'Aaja Nach Lai (Come Dance): Performing and Practicing Identity among Punjabis in Canada,' Ethnologies, 8 (I): 103-I24.

Nesbitt, Eleanor. (1997). "We are all equal': Young British Punjabis' and Gujaratis' Perceptions of Caste,' International Journal of Punjab Studies, 4 (2): 20I-217.

Okamura, J. (198I). 'Situational ethnicity', Ethnic and Racial Studies, 4 (4): 452-465.

Phinney, J.S., (1989). 'Stages of ethnic identity development in minority group adolescents'. Journal of Early Adolescence, 9: 34-49.

Remennick, L. (2003). 'The I.5 Generation of Russian Immigrants in Israel: Between Integration and Sociocultural Retention', Diaspora, I2 (I): 39-66. 
Ricucci, Roberta. (2010). 'Religion and Adolescent Immigrants in Italy: A case of identifying with or turning from their communities?' Journal of Contemporary Religion, 25 (3): 419-436.

Santosh, R. and Vij, S. (2003). The Hindu Youth Research Project 20or. Oxford: Oxford Centre for Hindu Studies.

Scheffer, P. (2010). The Open Society and Its Immigrants: a story of avoidance, conflict and accommodation. PhD. University of Tilburg.

Srinivasan, S. (2000). 'Being Indian, Being American: A Balancing Act or a Creative Blend?'. Journal of Human Behavior in the Social Environment, 3 (3-4): 135-158. 



\title{
CHAPTER 6 \\ A Case of Euro-Muslimness in Poland? The Polish Tartars case
}

\author{
Katarzyna Warminiska
}

The chapter focuses on Polish Tartars, the progeny of the Golden Horde - a small ethno-religious community which has thoroughly written itself into the Polish ethno-cultural landscape. The example of their history and contemporary life shows both the identity strategies undertaken by the groups which have a postmigration origin and which for centuries have lived in a social environment that is different from their own culture and religion, as well as - which is significant in the context of the debate in recent years concerning the possibility of a dialogue between the Islamic and Western worlds - the ways of building relations which, metaphorically speaking, can be described as good-neighbourly. I will illustrate the principles and the logic of building intercultural relations which, above all, are geared towards cooperation.

\section{Between 'post-migrant' and indigenous status}

Co-existence or the neighbourhood of cultures can take on different forms, starting with co-operation or neutral distance, and ending with conflict relationships. The logic and dynamics of these relations are derivatives of many factors: the character and a range of cultural diversity in a society on the macro-, mezzo- and micro-social scales; the dominating political discourse (official and existing in the public domain) dealing with the desired state of affairs in intercultural relations; the type of nationalism which determines the attitude 
towards ethno-cultural otherness; and finally factors of a historical or geopolitical nature.

One of the more important aspects of intercultural relations is those in which the host and the newcomers, or members of the receiving society and migrants, are entangled. Their presence in a given society can be relatively short-term or can last for many centuries, just as the reasons for their arrival can be different from the conditions on which their stay in their place of settlement is possible. In time, they can become 'one of us' (from the perspective of a receiving society) and assimilate; they can also, metaphorically speaking, become a personification of strangeness/a symbol of otherness; but they can also be regarded as the familiarized other.

The issue of migration and its consequences for the entirety of cultural relations within contemporary societies has found its place in the centre of attention of numerous social researchers. My goal is not to review the literature on the subject, as the main theoretical considerations were made in the Introduction (Leman, Toğuşlu and Sezgin), but to draw the reader's attention to one of the most interesting dimensions of intercultural relations between newcomers and their hosts, i.e. long-term relations.

In this part of Europe, Tartars - Sunni Muslims - invite curiosity because their location seems untypical, even exotic. Intriguing as it may seem, their exoticism is not the only reason for which they have been taken as an example. From the standpoint of migration issues, the community does not belong to those who, according to objective criteria, can be described as sufficiently settled in a given social place that their post-migrant status loses its significance. Members of this community have a sense of their separateness which partly results from their uncommon history. Also, their social environment communicates this very context of their being unique. Furthermore, the long time which has passed since the time of the Tartars' settlement in this part of Europe has resulted in their conviction about their right to be 'here', about being 'at home' in territorial, symbolic and identity dimensions.

Therefore, one can say that the group is positioned "in-between" as they are not really post-migrant and not really seen as indigenous. This ambivalent status makes it the starting point for my consideration of the issue in the title: Being a Muslim in Poland. 


\section{Polish Tartars: an introduction}

According to historical sources, contemporary Polish, Lithuanian and Belorussian Tartars are, first of all, the descendants of newcomers from the Golden Horde, who settled in the territory of the Grand Duchy of Lithuania in the first half of the fourteenth century. In those days, the population was not dense, as it is estimated to have been 12,000 or so in total. The main concentration of the Tatar population was in Vilnius and its surrounding areas - Troki, Minsk, Słonim and in the Podlasie area. The Tartar settlement in contemporary Poland - in Podlasie, where the biggest Tartar group (approximately 3000 strong) currently resides - began in the second half of the seventeenth century (Borawski; Dubiński 1986).

In the context of the issue being discussed, it is important to stress that arriving in the territories of Lithuania and later the Polish-Lithuanian Commonwealth meant, in the majority of cases, the specific location of the Tartars within the spaces of these political entities, both in reference to the location of the settlement (geographically) and in reference to their legal status based on the right to land and nobility and related privileges and obligations (which does not pertain to those who were not free or the descendants of Tartar prisoners). Generally speaking, they were allowed to settle down in return for military service. Although limited due to their religious otherness, they were granted some citizenship rights. Islam, the practice of which was not in any way restricted (except during the period of persecutions in the $17^{\text {th }}$ century), constituted a barrier, making it impossible to be fully included in the privileged group of citizens of the old Republic. As a result of marriages with Catholic and Orthodox partners, some of them became Christians and assimilated.

One can say metaphorically that, in a period of a few hundred years, a Tartar ethnic world was born and developed: not a temporary world but a wellestablished one. It had a specific character, in which such elements as religion (Islam), the nobility ethos as well as traditions and social and cultural values of the surrounding environment permeated each other, especially since their own ethnic language ceased to be the centre of communication as early as the sixteenth century. Within this world, community life went on, new mosques were built and cemeteries and places of remembrance established.

The situation changed only in 1918 when national borders divided the Tartar community for the first time. Statistics from 1930 show that there were about 6,000 Tartars in Poland, mainly concentrated in the Vilnius, Nowogródek, 
Grodno and Białystok regions. About 2,500 Tartars lived in Soviet Belorussia, and a little over I,000 in Lithuania. (Miśkiewicz 1990).

The consequences of World War II were also crucial for the Tartars' situation because at that time another breakup of the group took place. After the change of national borders, some Tartars took the decision to leave their local mother country in 1945 and, together with other Poles, left the territories then annexed to the Soviet Union and moved, first of all, to the Western Territories, and then to the Podlasie region. The immigration movement included one third of the population which had lived in Poland before the War. The borders, which divided the Tartar community for many years to come, not only brought about physical alienation of the members of the group but also, in consequence, contributed to the creation of different Tartar ethnoses.

Even in the interwar period the community functioned under the common name of the Polish-Lithuanian Tartars, which had historical connotations. Today, however, we speak of Polish Tartars, Lithuanian Tartars and Belorussian Tartars. The ethonym (composed of two elements) can serve as an interesting indicator of an identity situation among contemporary Tatars. Firstly, it informs one about the Polish-Lithuanian Tartars' common origin, their ethnic history, culture or specific Muslim religiousness, which - when considered together - decide the separate, unique character of this historical community.

Secondly, the adjectives "Polish", "Lithuanian" or "Belorussian" are not just territorial indicators of a group's roots in the meaning of contemporary state locations but also - as the case of the Polish Tartars shows - a national identification or - in the case of the Lithuanian or Belorussian Tartars - a potential piece of information about community ties or citizen loyalty.

Currently, the Tartar population in Poland numbers roughly 5,000 according to estimates by the Muslim Religious Association. ${ }^{\mathrm{T}}$

The national census of $201 \mathrm{I}$ showed that, in Poland, it had almost 2,000 members. The legal status of Polish Tartars was regulated by the Act of 2005 on national and ethnic minorities and on regional languages, according to which they are a recognized ethnic minority in Poland. It gives them some rights and financial support from the state and its institutions.

Today's Polish Tartars do not constitute a socially compact community, as they are dispersed all over Poland, living mostly in smaller or bigger towns. The reconstruction of a community life of the past has been only partially successful. At present, Białystok, the capital of the region, and the neighbouring towns are the area where over half of the members of the Tartar community live, although 
before WWII only some Io\% of them lived here. We can say that contemporary Tartars do not cultivate their traditional community life around the place of their residence, but rather around moments of being together on religious, ethnic or family occasions, although their kinsmen in Lithuania still live in conglomerations, like the one in the village of Sorok Tatary, where a community of several tens of Tartars have lived for over 450 years.

They gather in two associations - religious and ethnic. The Muslim Religious Association keeps eight religious communes, linking for the most part Muslims of Tartar origin. Today, the Muslim Religious Association and its ethnic organization - the Polish Tartars' Association - have their seats in Białystok. And so, near Białystok, in the villages of Kruszyniany and Bohoniki, there are two old mosques and cemeteries which date back to the $18^{\text {th }}$ and $19^{\text {th }}$ centuries (from among 17 temples and 39 cemeteries they had during the interwar period). These places have, as my interlocutors declare, the most symbolic meaning to them. Once typically Tartar, at present these villages are inhabited by a few families, and they constitute places where during their major religious holidays Tartars from all over Poland arrive to pray together in the mosques and to visit their ancestors' graves. Another relatively socially compact group of about 200 Tartars lives in Gdańsk.

They have, besides the aforementioned old mosques, a temple in Gdańsk, three cemeteries and a few houses of prayer. In 2004 the post of Mufti was established. Being a representative of the group, he leads the religious life of the Muslim community.

For many years, the Muslim Religious Association was the only religious association connecting Muslims in Poland, and, for the most part, the Tartars functioned as imams. Under the organization's statutes, everyone who came from a Muslim family automatically became a member of the Association. In practice, this meant that he/she also had Tartar origin. It was so because for many years the Polish Tartars shared a conviction that they were the only group of Muslims in Poland that could be distinctly separated. The stereotype that every Tartar in Poland is a Muslim and every Muslim in Poland is a Tartar confirmed this. The awareness had both historical roots, as the Polish Tartars had always lived in relative isolation from the Islamic world, and political roots because the contact of members of this community with other Muslim believers, especially in communist Poland, boiled down to more or less sporadic and intensive meetings with students from Muslim countries. The latter, among others, served as teachers of religion in the absence of those members of the group who were able to run such educational courses. 
The situation started to change in the 1990 s when Muslims from other countries started to settle in Poland temporarily or permanently, and when conversions to Islam began to occur. What is more, in 2004 another religious association was legalized - the Muslim League of Poland. Those factors have brought about a change in the formula of membership of the Muslim Religious Association, which for the past few years has been admitting Muslim believers who have Polish citizenship or a permanent residence card. Consequently, the ethnic make-up of the Muslim Religious Association has changed; at present I/3 are non-Tartars, and the communes are led by people from outside their ethnic community.

\section{A complex configuration of identifications}

My research on Tartar identity has shown that members of this group are carriers of a multiple identity in the ethno-cultural sense. ${ }^{2}$ For members of the community, combining and integrating three aspects in one identity project, i.e. the religious, ethnic and national-citizen aspects, is a legacy and obvious reality. The image of the world based on which one can be a Muslim, a Tartar and a Pole at the same time has been permanently domesticated by group tradition and ideological visions as well as by the experiences of individuals. The existing identifying status $q u o$ is a result of both identity choices and also a certain historical logic.

Their being Polish comes from the fact of their acquisitive prescription (of over 600 years), cultural community (the language), historic traditions (especially military ones), historical memory and citizenship. Their being Tartars, however, is determined by their origins, historical memory, traditions, but most of all by their religion, Islam, which delineates the ethnicity of the group very strongly. I wish to stress, in general terms, that in the case of this group, on the identity level, we are dealing with a strong mutual permeation of ethnic and religious elements, like the abovementioned stereotype. Therefore, we can talk about a far-reaching ethnicization of religion. Moreover, another strong component of a collective identity in its ethno-cultural aspect is Polishness, understood as a national or state identification.

Polishness locates itself, metaphorically speaking, between an obligation and a fate. The fact of having (participated) lived in Polish society for many decades brought about a far-reaching enculturation into Polishness within the aspect of popular culture and also within the values of the national canon of 
values, attitudes, visions of the history, everyday and festive codes. This finds its expression in the manner of argument for being Polish, which is deeply rooted in the traditional/dominating discourse, although the civic element has become stronger in recent years, and it is stressed in many declarations that citizenship and nationality are two separate issues. It is interesting that the scholarly discourse which postulates the existence of multiple identities goes hand in hand with the declarations of the members of the community and, to a certain degree, is used reversibly for self-description. So one can say that it has become an element of a reference knowledge.

At this point I would like to mention yet another issue. The Tartar community is distinct in respect of religion as its members practise Islam. Their religion is tightly bound up with the ethnic dimension of identity, although for some of the group's members it is a dimension that functions independently of the ethnic one, which is expressed in the name used to mark the group: Polish Muslims. This is not the place to explain the role of religion in marking the ethnic boundaries of a group but, in the context of a collective memory of the type I am speaking about, the fact of preserving Islam is equivalent to preserving the separateness of the ethnic group and, like Tartarness, an argument of a dual character. Perhaps I should just mention that the religious past constitutes a crucial key to deviations from Islamic principles, especially in relations with Muslims from outside Poland. An ultimate argument is those 600 years of being here, in the sea of Christianity, as one of my interlocutors said, and preserving the religion of the ancestors.

This complex identity configuration, resulting from the mutual permeation of cultural areas as a system of reference for building self-definition, i.e. those connected with the Tartar origin, religion and Polishness, causes the processes of building symbolic borders of the community to be dynamic and multifaceted. As my interlocutors declare, each of the mentioned elements is important to them and, in a sense, inalienable, despite the fact that their importance differs depending on how a given subject constructs his/her vision of self and the community.

To illustrate this issue briefly, let us refer to the name as an important emblem of the group. Some of its members name "him/herself" as "Polish Tartars Muslims", others as "Polish Muslims", "Poles of Tartar origin". If each of these terms were to be treated as a declaration of identity, not just as a customarily used name, then one would be able to note the complexity of this system of identification. Stressing or omitting one of the three key elements in one's declaration does not exclude the others. It does show, however, his/her identification preferences in a given time and place or a moment in that person's life. One should also remember 
that that social identity is always constructed vis a vis others, be it members of one's own group or a social environment in a broad sense, and this fact define a possible area for the negotiation of social recognition.

For instance, if for some of the members of the group it is being a Muslim (let us add a Polish Muslim) that is most important, and if they emphasize this community identification in relations with others, then perhaps they will encounter a barrier caused by the situation where in popular discourse they function, first of all, under the name of Polish Tartars - Polish Muslims. Such a situation took place when the Muslim Religious Association celebrated its $80^{\text {th }}$ anniversary, when during the festivities the Mufti used in his speech the term "we Polish Muslims", while the representatives of local authorities addressed their words to the Polish Tartars saying "our Tartars". It has to be stressed that this did not stir up any objections on the part of the representatives of the group. Nevertheless, it was an interesting example of the interplay between internal and external aspects of social identity.

\section{Co-operative neighbourhood relations}

In the case of Polish Muslims, being a Tartar in Poland translates into a variety of institutional, ideological and less formal daily activities which are based on such an interplay of similarities and differences when delineating symbolic borders of the community, so that on the one hand its religious and ethnic separateness could be preserved, and so that it was possible to delineate a possibly wide field of complementarity with the dominating group on the other. Hence, the identity aspect and social practices are equally important.

In order to describe strategies which members of this community adopt in multicultural relations with representatives of other ethnic and religious groups which are situated on similar or dominating social positions, one has to take note of a few variables.

Firstly, nowadays Poland is a country of a relatively low degree of saturation with multiculturalism in its ethnic and religious aspects. The Białystok region, however, where the largest population of Tartars is located, is not only a region of borderline character but also an area where the proportion of ethnic and religious minorities in the general population is higher than in other regions (Belarussians, Orthodox, Roma). This makes us take into consideration the specificity of Tartar actions on a local level. 
Secondly, in public discourse at the national level, Tartars seldom appear as social partners/subjects, and in the recent years they were talked about (as Muslims in Poland, our Muslims, Tartars, Euro-Muslims) in the context of the $200 \mathrm{I}$ events, publications in the press printing cartoons depicting Mohammed, and the problem of headscarves in France.

These circumstances became a pretext for Tartars to communicate a vision of mutual relations. Also, the Polish press reports on the fact that Polish Tartars, who are Muslims who have been living in Poland for centuries, celebrate Kurban Bajram and Ramadam Bajram.

Thirdly, one cannot but agree that, in the group leaders' opinion, the Tartars as a numerically small group have a marginal position among other ethnic and religious minorities in Poland and cannot expect (in fact, they do not expect) to become important partners in relations with at least the authorities. As they say, they are local exotica. It should be stressed that they do not present to the dominant group any demands addressing discrimination. To cite A.P. Cohen's (1975) typology, one can speak of a strategy of "assertive marginality", i.e. a way of constructing their identity so that the marginality stigma is minimized by turning it into a positive value.

Going back to the analysis of the rules or logic behind building neighbourly relations between different religious and ethnic communities, the example of Polish Tartars is a good illustration of a strategy focused on cooperation. The mechanisms of such actions are based on a game of similarities and differences while delineating the symbolic borders of a community in such a way as, while preserving their own cultural resources, to mark a possibly large field of complementarity with the dominating group and to build an image of a "tamed other" within Polish (Christian) society.

If we understand neighbourhood on the level of coexistence within a larger community of groups that are different in respect of culture, then these rhetorical strategies gain special importance when used by members of a discussed group, especially its leaders, who speak about their Polishness as a way of stressing cultural, historical closeness. And so, such values and attitudes are manifested as Tartar patriotism, their involvement in the defence of the country, loyalty, from time almost immemorial being part of Polish culture and tradition. At the same time, the Tartars declare that Poland is their mother country and that they feel themselves and are considered by others to be Poland's "loyal sons", to use the Tartar leaders' rhetoric. 
In this case, the religion of Islam is undercommunicated, as a crucial element of Polishness is Catholicism, and this specific criterion potentially excludes the Tartars from the community of nationals. Polishness, on the other hand, is positively associated with Islam as building the image of the Tartars as Polish Muslims, i.e. "ones of their own", "proven", ones that can be relied on. Such rhetoric appeared in Tartars' statements especially when issues relating to Muslim extremism, terrorism and the threat of the "war between civilizations" were tackled in the public discourse.

In such circumstances they usually overcommunicated their cultural and historical ties with Poland as a representative of Western civilization. They condemned aggressive actions on the part of some Islamic groups; they educated "others", showing the peaceful "face" of their religion, by using their own example. Another important issue was their indicating cultural community with Europe rather than with that which is Arabic. In this way, they clearly showed their hierarchy of values.

It is also interesting that, when the other Muslim association (besides the Muslim Religious Association) was legalized by the authorities in 2004 some Tartar leaders expressed their disappointment with such a move, and said that in such a situation they would not be able to take care of the Polish interests in the broadly understood world of Islam because those interests had been passed to other than Tartar hands. In the case of the discussion on the "scarves", they also clearly stressed their Polish/European roots, indicating cultural distance from "the brothers in Islam", which did not result in the depreciation of their own religion, but showed its positive character, i.e. - Polish Tartars -Muslims.

Another aspect of neighbourhood in its "global" dimension is their involvement in joint ventures which have the character of organized cooperation. In this case, since 1997 the Tartar Muslims have participated in the Joint Council of Catholics and Muslims, which constitutes a forum for religious dialogue. The Council works to strengthen peace, desisting from aggression in mutual contacts, wants to prevent conflict and stereotypes by getting people to know each other and by mutual understanding.

For several years now, educational initiatives for a religious dialogue have been underway in cooperation with different institutions. For instance, in June 2008, the Centre of Culture of the Polish Tartars in Gdańsk organized a conference entitled "Islam in Europe". Alongside academics, among the invited guests were leaders and representatives of the Jewish and Catholic communities. And in Sokółka, a local annual event called "Sokólski Orient" is organized, during which 
Byelorussian, Roma and Tartar folk groups from Vilnius perform. The theme of the event is "Culture unites nations".

Moreover, the organizers of important religious or ethnic celebrations invite representatives of the Catholic church (bishops and local priests) and sometimes representatives of the Orthodox church to be present as guests of honour during the festivities.

Therefore, one can say that there are many different institutionalized levels or platforms on which the "neighbourhood" of cultures, nations and religions is implemented, where the platforms are created and initialized by representatives of the community or in which they participate.

Community coexistence has yet another dimension: that of everyday relations where the logic and character of mutual relations come to the surface, where there are fewer declarations and manifestations of attitudes and more practical social life. In this case too one can talk about a cultural strategy of neighbourhood on the part of representatives of the discussed group that is expressed through such a construction of symbolic boundaries so that it is possible to delineate the widest possible field of complementarity with "others". Such an approach assumes striving to accept the existing differences, not only as a fact but as an asset. In any case, this is a typical strategy for minority groups oriented towards cooperation rather than competition or conflict.

Conversations with members of the group paint the following picture of neighbourly relations. Usually, the fact that they are Tartars and Muslims is well known. As they declare, among the people from their close social environment, the fact stirs friendly interest, rather than dislike or distance. They have friends both among "their own kind" and among many Catholics and Orthodox, and that makes no difference to them. They stress that in their relations it is the character of a person or mutual attitude that matters, not the person's ethnic origin or religion. Care for good neighbourly relations is expressed through respecting holidays, whether Catholic or Orthodox. Therefore, they abstain from activities which, according to the traditions of other religions, should not be performed. For instance avoiding making a noise or engaging in deep and thorough preholiday tidying. Friends from outside the group are guests at such celebrations as weddings or birthday parties, while they are invited to and participate in similar social occasions.

This picture of good neighbourly relations can be overshadowed by a fact which was present in many statements: in their childhood, at school or in the playground, situations frequently took place in which my interlocutors were ridiculed or 
called names because of their different religious or ethnic origin. Sometimes they were called "you Tartar gob", nowadays more often "binladens". When asked about their views on those experiences, they would blame such behaviour on "children's silliness" and lack of understanding rather than verbal aggression, in this way minimizing or marginalizing sources of possible conflict situations.

\section{Invisible Muslimness}

In the context of discussing multicultural relations, it is also important to note that the Tartars' religious distinction is not visible in a social sense in many everyday situations. This is so partly because of the essence of the Tartar Muslim practice, and partly because of the nature of the functioning of this religious community which gathers not so much around places as around common moments of being together.

The Tartar religiousness first of all has a private character as it concentrates within a family. When asked about their religious practice (which differs from the "orthodoxy" as they are well aware), my interlocutors stressed many times that they had to "adapt" to their surroundings, giving up some of the requirements of their religion at the same time. In their opinion, however, this does not change the fact that they are Muslims in their hearts and actions, only their Islam is "local" and Tartar. The few situations in a year when Polish Muslims celebrate their holidays together, for example Kurban Bajram, during which they publicly sacrifice animals, take place in relatively distant places away from their homes. I give this example as this custom clearly communicates a religious distinctiveness and can shock because of its bloody character. The two mosques to which Tartars from all over Poland arrive to pray together are located in small villages and their Christian (Catholic or Orthodox) inhabitants are well accustomed to this Muslim custom. They are observers of the ceremonies who keep their distance and do not enter the mosque.

The everyday life of the group is also not deeply marked by what could make their religious practice clearly visible. For instance, the majority do not say their prayers five times a day and religious services take place on Sundays when their neighbours attend services too. Besides, their lifestyle lacks those elements which can be associated with Arabic Islam, such as headscarves.

This issue is connected with another interesting topic, namely a wider cultural location of Polish Tartars-Muslims. I mean their Europeanness as a key to their 
geopolitical location, hence an argument in debates on their familiarity or otherness in Poland as a part of Europe.

\section{Euro-Muslimness}

Since 1994, the Tartar ethnic union has been a corresponding member of the Federation of European Union Ethnic Groups at the EU Council, but the Muslim Religious Association, which links Polish Tartars and represents the religious interests of that community, is associated with world Muslim organizations. This fact clearly shows the dual or (in a cultural sense) borderland character of the group location, which in a symbolic sense locates itself between the Western and Islamic civilizations, to use Samuel Huntington's terminology. On the one hand, for hundreds of years this group has been connected with Europe geographically and culturally (through its ties with Poland), and on the other hand, through Islam, with the world community connoted through values other than the ones typical for the place of settling. The cultural thread of Europeanness was already shown in my research on the identity of Polish Tartars in the 1990s. Even then, my Tartar interlocutors were mentioning their Europeanness when the issue of their religiousness was touched upon, which, in the eyes of Muslims from other countries, was not considered as being completely in line with Islamic orthodoxy. The Tartars would claim, however, that they were completely loyal/orthodox Muslims and the Islam they were cultivating had a specific Tartar character that was as valid as its Arabic version. They would stress differences in morals and civilization relative to other Muslims, their religious and everyday culture by valuing it as being more European or civilized (Warmińska 1999). It is worth adding that not all members were of the same opinion and some would negatively perceive the deviations from orthodoxy and would strive for cleansing Islam of what was new - Tartar.

This thread returned at the beginning of the 2000 s, especially after September II, 200I, and took on a new meaning in the context of the international discourse which placed Islam in a new political and cultural light, e.g. presenting a conflict between the Western and Muslim civilizations. It was then that the group's leaders, when required to take a position on their relationship with the Arab states or toward Islamic terrorism, clearly distanced themselves from this type of action or ideology. One of the weighty arguments was the Europeanness of the group, professing other values. As one of the activists said, "We have chosen 
our own path of development as Polish or European Muslims... We think that acculturation with the Polish or European environment is not wrong; on the contrary, we believe that the Muslim world should Europeanize itself, similar to Japan, which could contribute to its peaceful growth"(Chazbijewicz 200I). In one of the interviews, the above-quoted Tartar leader referred to himself as a 'Euro-Muslim, thus signaling that religion - Islam - and nation or culture are two separate issues and that he feels that he belongs more to the European culture than, for instance, to the Arab culture, with which Islam is often associated (Euroislam 2004). In the context of Polish Tartars, the concept of 'Euro-Islam' has divided the group. Part of the group, following the line of the current MRU's policy programme and their Mufti, claims that Islam is one and the term 'EuroIslam' distorts the essence of the religion and is one that should not be promoted.

The Europeanness of Polish Tartars - Muslims is at times mentioned in statements of the group's representatives when asked especially by journalists about Muslim customs which they profess. When talking about the group's customs, they stressed their European character, rather than the Arab one which is foreign to them from the culture and civilization standpoint. As one of the Tartar women stated in an interview in the daily Rzeczpospolita, 'Imams try to introduce customs which are foreign to the Tartar culture. Our mothers and grandmothers did not wear scarves. We are Europeans. Our girls would rebel against it.' (Południk 2004).

When considering the issue of symbolic boundaries and when describing their functioning in intergroup relations, one must see in what contexts they take on the form of a barrier or a wall. Metaphorically speaking, they are clearly visible "inside the mosque" and they pertain to the relations between the Muslims of the group in question and the non-Tartar Muslims.

In the declarative sphere and partly in social practice, both communities maintain some relations. The Tartars refer to non-Tartar Muslims as "brothers in Islam”, stressing a certain fundamental bond among believers regardless of their ethnic provenance. Similarly, like the majority of the representatives of the Islamic world, they were indignant at the publication of the Mohammed caricatures, and in this context they communicated their community with the world of Islam.

In any case, the Mufti, a person who for many years lived and received education in Saudi Arabia, has been acting for the integration of the two Muslim groups. Suspected of pro-Arabic sympathies, during his initial work he was treated by Tartars with a certain distance, and only after a few years did he win their respect. This, however, still does not change the fact that the two sides separate 
themselves from each other. The separation is visible in the fact that they pray separately, and Muslims from outside the group do not participate in religious holidays which are celebrated in the "Tartar style". Hardly ever do they establish or keep close relations except for religious occasions even if there is no language barrier.

As I mentioned earlier, students from the Arab countries were religion teachers and this fact, except in a very few cases, did not establish non-formal relations. It is symptomatic that, if we look at the "makeup" of the groups praying in the Gdańsk mosque during Friday prayers, the majority come from outside the Tartar group, while those praying in the old mosques are Tartars. The reasons for this situation are complex. When listening to the members of the group in question one can hear arguments which point to the cultural strangeness of other Muslims, to a different lifestyle, customs and lack of willingness to make contact, or their isolating themselves. The differences are also seen in the sphere of religion: according to the Tartars, the "Arabs" (as they often call the Muslims who do not belong to their group) pray differently, faster, in a less celebratory manner than the Tartars, and the melody of the prayer is different too. Moreover, in the Tartars' opinion, the "Arabs" criticized their Muslim practice, reproaching them with numerous mistakes and departures from the norm. To a certain extent, the Tartars share a dislike of the "Arabs" with the Poles. The scope of the solidarity with the Islamic world depends on the social context, sometimes the feeling of unity appears, but more often there is a distance.

\section{Conclusion: an in-between consciousness}

To sum up, the above mentioned unique in-between status of the group results, first of all, from the context - the migrant genesis of this community in Poland. What is important, using the words of members of this group, is that in their own eyes they are both newcomers and indigenous - Tartars, Tartars-Muslims, just Polish ones. That is how they are perceived by the broadly understood social environment. A significant role is played by the Tartars' long settlement which, on the level of everyday and ideological experiences, has allowed others to get accustomed to their otherness or to write themselves permanently into the Polish landscape and as a familiarized other. However, on the level of identification processes, not only has it released strong ties with Polishness but also deep roots in their own, local, Polish-Tartar-Muslim social world. 
Secondly, this ambivalent status comes from the location of this community in a specific cultural borderland in a symbolic dimension - between Polishness and Tartarness/Muslimness; Muslimness and Polishness; and finally between Polishness/European Muslimness and Arab/orthodox Muslimness. Being 'between' these dimensions can release both certain dilemmas or identity tensions but also, as I wanted to show, it creates an identity status quo based on which individual members of the community can give sense to their lives.

The above considerations pertain, first of all, to the Tartar vision of relations with their neighbours. Therefore, we can see a group which strives to impose on the social environment, both near and far, such an image of themselves which would allow them to be seen as good, trustworthy neighbours that have been present in the Polish cultural space, who area familiar 'other' rather than strangers. Polish Tartars appear as a community which, by striving to be considered separate, is building its relations with the 'neighbours', one that is focused on cooperation rather than on dichotomization. I wish to stress that, in the case of Polish Tartars, to be a Muslim in Poland translates into a variety of identity strategies, from the point of view of both the institutional and less formal, everyday aspects.

\section{Notes}

I The main religious organization of Polish Tartars, the Muslim Religious Association, was founded in 1925 and reactivated as early as 1947.

2 The analyses presented in this part of the chapter were prepared on the basis of the anthropological research I have been conducting among Polish Tartars since the beginning of the I990s. I collected the research material over many years during my in-depth interviews with members and the leaders of the group. I have also analysed the printed materials published in the Tartar press and on the Internet. Furthermore, I participated in group events during which I conducted participant observation.

\section{References}

Borawski, P., Dubiński, A. (1986). Tatarzy polscy. Dzieje, obrzędy, legendy, tradycje. Warszawa: Iskry.

Cohen, A.P. (1975). 'Social Identity and the Management of Marginality', Sociological Review, February.

Chazbijewicz, S. (200I). 'Rozmowy partnerów Onetu. Selim Chazbijewicz - rozmowa,' 28.11.200I, www.onet.pl 
Euroislam (2004). Gazeta Wyborcza, 17-18.07. 2004.

Miśkiewicz A. (1990). Tatarzy polscy I919-1939. Warszawa: PWN.

Południk E. (2004). 'Szczeropolscy Tatarzy i partia Boga', Rzeczpospolita, O4.I I.

Warmińska K. (1999). Tatarzy polscy. Tożsamość religijna i etniczna. Kraków: Universitas. 



\section{Part II:}

Non-Migrant, Anti-Islam Interactions/Identifications 



\section{CHAPTER 7 \\ 'Anti-Islamization of Europe' Activism or the Phenomenon of an Allegedly 'Non-racist' Islamophobia: A Case Study of a Problematic Advocacy Coalition}

Vincent Legrand

In the first chapter in this second Part, this time dedicated to the non-migrant and anti-Islam interactions/identifications, we present research that is based on the observation of a series of actors in Western Europe grappling - directly or indirectly - with a growing cultural and religious diversity, with Islam as a new religion asserting itself at the forefront, in an area which is traditionally mainly Christian and secular. More specifically the first section presents a synthesis of 'anti-islamization of Europe' activism, setting out the context, the actors and main features of the phenomenon. The second section is an original case-study based on participative observation, informal exchanges of views and data collected at meetings ${ }^{1}$ of the Organization for Security and Cooperation in Europe $(\mathrm{OSCE})^{2}$ organized by its Office for Democratic Institutions and Human Rights (ODHIR) in Vienna and Warsaw in 2009. In this setting I observe two types of organizations in a tentative form of what Paul A. Sabatier has conceptualized as an 'advocacy coalition' in the dialogue process around the issues of Western civilization, Islam and Christianity in Europe: on the one hand Christian or Christian-inspired (Roman-Catholic and Protestant) organizations; on the other hand what I call 'Defence of Western civilization' organizations.

As we will see, this process related to intertwined issues pertaining to current dynamics of identity change in Habermassian post-secular Western Europe (as defined in the General Introduction to the present book and implicitly referred to in the introduction to this chapter) is not without tensions expressed by clashes between several clusters of values, rights and reference points, such as freedom 
of religion, freedom of expression and hate speech legislation. Christian actors are caught up in a paradox of asking for a Christian-faith margin for manoeuvre in the prevailing secular order while at the same time being uncomfortable about sharing this principle with believers of another faith, Muslims. On their part, 'Defence of Western civilization' actors claim that they 'put the facts on the table' and deliver information about the 'real Islam, which would threaten both Europe's secular liberal democratic order and Christianity, which would be challenged - in their view - not so much as Faith but as culture and identity, echoing the renewed role played by religion in Western societies as identified by Casanova and Göle (cf. General Introduction to the book).

\section{'Anti-islamization of Europe' activism}

'Racism is the lowest form of human stupidity, but Islamophobia is the height of common sense', so asserts the slogan of the Stop Islamization of Europe (SIOE) movement. SIOE is a transnational network of 18 national associations, based mainly in Europe. It started with a meeting between the Danish political party Stop Islamificering Af Danmark (SIAD - Stop the Islamization of Denmark), founded by Anders Gravers following the Mohammad Cartoons Controversy in 2005, and the English association No Sharia Here, which became the English branch of the SIOE headed by Stephen Gash. They were then joined by the German Pax Europa organization. In 2010 SIOE joined the European Freedom Initiative, which is composed of a series of national Defence Leagues (I8 at the moment, also mainly based in European countries and following the model of the initial English Defence League, created in 2009).

The focus here is on civil society organizations - national and transnational associations and networks - thus not including political parties sharing the same agenda such as Geert Wilders' Partij voor de Vrijheid in the Netherlands - even if there are some links between some of these organizations and political parties, whether recognized or denied, or if some of them may form embryos of new political parties (Weis, 20II: 5I-64) or themselves emanate from former political groups, as in the case of SIAD.

From SIOE's slogan we can see that it endorses Islamophobia, proclaiming itself to be non-racist. The SIOE clearly distances itself from extreme right-wing and xenophobic movements and parties and claims that it defends the values of the European liberal democracy: it equates Islam with a form of totalitarianism 
exactly like Nazism and Communism, one that would, by its very nature, be incompatible with democracy ('Islamofascism').

So, is this indeed a non-racist phenomenon? Or is it a new form of racism: xenophobia in 'new clothes'? If it is not racist, extreme right-wing, neither Nazi nor fascist, has it some connections with such currents? And whatever the case, does it nevertheless contribute to a xenophobia which targets Muslims?

In order to answer these questions, I will first address the context in which this phenomenon emerged as well as its main features. I rely here on (too) few major secondary sources (Fekete 2011; Carr 2006) as well as on complementary materials collected by me (Legrand 2007).

In the short term we can see the emergence of such a phenomenon in the context of different events in the course of which Western audiences have felt themselves under attack from 'Islam': the terrorist attacks of II September $200 \mathrm{I}$ in the United States, those of Madrid (2004) and London (2005), the assassination of the film-maker Theo Van Gogh in the Netherlands (2004) and the Danish Cartoon Controversy (2005). In the long term let us just mention here the crucial evolution that in recent decades in Western Europe transformed the issue of migrants, Gastarbeiter, into an issue of North-Africans and Turks before being transformed into one of Muslims and Islam (for more details about the long term see Fekete 20ri).

For anti-islamization activists the immigration of Muslims to Europe is perceived as massive and depicted in terms of a demographic conquest. As the German president of Die Freiheit party René Stadtkewitz (2011: 165) says, 'what we see today is not Muslim fighters at the gates of Vienna. The fighters are now in the very midst of our countries. Today they use our schools, banks, social system and most of all our tolerance and our weakness to fight against us'. It is assumed that Muslims will become the majority in Europe, and when they are, they will impose their religion and introduce sharia (Islamic law). In this perspective Muslim minorities will be about to or will already have set up 'Islamic enclaves' through sharia courts (Doc. 6). In their eyes Islam is in essence a warlike and criminal religion, which is "unable and unwilling to adapt to different historical and cultural settings" (Fekete 2011: 36). In their view, Islam is also in essence political, and as such is equated with a totalitarian violent political ideology termed 'Islamofascism'. Not only is Islam essentialized, Muslims are too: they are assumed to be violent people unwilling to live at peace with non-Muslims and fundamentalist in their literalist interpretation of the Koran. A 'nuanced' synthesis has been formulated by René Marchand (2011: 149), an orientalist 
journalist active in the French organization Riposte laïque: "There are Muslims who are moderate by their nature or by reason; there is no moderate Islam." This last point is linked to the general suspicion that is directed at all Muslims, who are assumed to be masters of 'double speak' and 'taqiyya' (dissimulation) (Fekete 20II: 35). In the final analysis, the 'non-racist' perspective puts it in the following way: Muslims are the first victims of their own religion and they should leave Islam because, formulated in a radical way, the only good Muslim is an ex-Muslim.

Now comes the second part of the picture. The main threat is not from Muslims themselves, who have migrated and settled in Europe; rather the responsibility lies with those who made this migration possible, and are still doing so: the 'indigenous' people of Europe, in particular, the 'political establishment', who permissively and naïvely supports pro-migrant and multicultural policies, either by omission, guilty surrendering or by multiculturalist sensitivity. Most politicians have become "apathetic. (...) They have become blind, they have become accommodating and are not aware of the extent to which our Liberty is threatened" (Stadtkewitz 20II: 164); also, politicians are accused of 'collaborating' with Muslims "in order to avoid any problems or tension" (Gravers 2011: I०8).

We can easily see here Anders Breivik's worldview that motivated his attacks in Oslo and on the island of Utoya in July 20II. He did not attack migrants, but rather his country's government (targeting official buildings) and fellow citizens of the Workers' Youth League, a political youth organization affiliated to the Norwegian Labour Party, which commits the 'crime' of multiculturalism and in so doing - allegedly contributes to the decline of civilization in Europe (for a broader view of the political context in which these attacks took place see Harry's essay in the present book on the issues of nationalism, religion, secularism and multicultural politics in present-day Norway).

Concerning actors sharing this worldview - or part if it - Liz Fekete (2011: 30, 31 \& 38) makes the correct distinction between those who support the notion of a deliberate conspiracy to Islamicize Europe (in extreme right, neoNazi and counter-jihadist circles) and those who claim to observe and deplore the Islamization of Europe, but without attributing it to a deliberate conspiracy (in neo-conservative and cultural conservative intellectual and political circles). In this regard the best-known benchmark conspiracy theory is called 'Eurabia' after counter-jihadist Bat Ye'or's title for a book in which the author defends the thesis of a secret project between European politicians and the Arab world for the 'Islamization of Europe', the purpose of which is "to destroy America and Israel, with Europe a doomed continent on the brink of cultural extinction in 
the face of a relentless and co-ordinated campaign of domination of Muslims to transform it into an Islamic colony called Eurabia", where Europeans would become dhimmi people (Fekete 20II: 43; Carr 2006).

Conspiracy or not, what is at stake for anti-islamization activists is nothing less than the decline of civilization in Europe - a strong existential threat at the core of identity and in the transmission of identity. This strong existential threat is so acute that it is an alarmist, catastrophist, kind of apocalyptic vision and framed in terms of a 'demographic time bomb' (an element to which I will critically come back later) (Carr 2006).

\section{Case-study: a problematic advocacy coalition between Christian faith-based and 'Defence of Western civilization' actors at OSCE, Vienna, July 2009}

As stated above, the present case-study is based on participative observation, informal exchanges of views and data collected at meetings of the Organization for Security and Cooperation in Europe (OSCE) organized by its Office for Democratic Institutions and Human Rights (ODHIR) in Vienna and Warsaw in 2009, in particular the 'Supplementary Human Dimension Meeting on Freedom of Religion or Belief held in Vienna on 9-10 July.

This meeting tackled issues related to the status of religious communities and places of worship, concerning, among others, religious minorities, in terms of the problematic formulated as "from commitments to implementation" (Legrand 2009a). It was attended by most of the Organization's 56 Member States (covering countries outside Europe, stretching across the Northern Hemisphere from Vancouver to Vladivostok) together with about a hundred people representing 'civil society', NGOs, churches, religious organizations, philosophical nonconfessional bodies and academic institutions.

In terms of minority rights the OSCE, among others, used to work in the fight against anti-Semitism and Islamophobia. But a few months before the meeting being studied the OSCE had also started - with a Round Table organized on 4 March in Vienna - to work on 'Intolerance and Discrimination against Christians', also in Christian majority contexts and areas, on the basis of a newly constructed agenda: not only minority but also majority religions may be the object of violations of religious freedom, and this happens as much 'west of Vienna' (the former Cold War's 'Free World') as 'east of Vienna' (Legrand 2009a). 
With this as a background and in this context I was able to observe at the Vienna meeting of July 2009 two types of organizations in a tentative form of 'advocacy coalition' (Paul A. Sabatier's concept) in the dialogue process around the issues of Western civilization, Islam and Christianity in Europe. This was not however without tensions, as we will see: on the one hand, Christian organizations -Observatorio para la libertad religiosa y de consciencia (Madrid), Alliance Defence Fund (USA), Paneuropa Union (Paneuropabewegung), the Vienna-based Platform Christianophobia in Europe (also called Observatory on Intolerance and Discrimination against Christians) and Evangelischer Aufbruch in Deutschland (EAD); on the other hand, what I call 'Defence of Western civilization' organizations (liberal/secular-oriented and referring to the JudeoChristian heritage in cultural terms): Bürgerbewegung Pax Europa (BPE), International Civil Liberties Alliance (ICLA, USA), Mission Europa - Netzwerk Karl Martell and the Wiener Akademikerbund.

I will elaborate later on on the profile of this second type of organization, but it is worth mentioning here straightaway another type of actor present at the meeting under study and sharing a secular-oriented profile but who should not be confused with them. This other type of actor is classically defined and defines itself as 'secular humanist', like the European Humanist Federation (EHF) and the Belgian Centre d'Action laïque (CAL) and shares some features: secularism (StateChurch separation, rule of (secular) law), emphasis on religion and belief seen as a private matter, freedom of religion and freedom from religion (rights of nonbelievers). Even if it is concerned about some tendencies in Muslim communities (such as the refusal to countenance mixed-gender swimming pools), the focus remains - at least in this setting - on the traditional religion present in Europe: Christianity, in particular the Roman Catholic Church, with its clerical structure and source of political influence in public affairs. As such it is not 'obsessional' about Islam in particular. All religions that would be uncomfortable with the emancipatory humanist achievements of the Enlightenment are a matter of concern. I did not observe in this setting any connections with 'Defence of Western civilization' organizations.

In order to investigate this, I take as a basis the Joint Statement of NGOs to OSCE and to participating States at the Vienna ODHIR meeting of July 2009, which was signed by the above-mentioned Christian organizations (Doc. I). On their part the 'Defence of Western civilization' organizations were approached to sign up, but did not rally to the cause. 
Before going through their recommendations, let us first mention a general remark made in the Statement concerning the context as described above: "[i]t should ... be noted that the infringement of religious freedom affects both, minority as well as majority religions". In this regard, we read elsewhere that 'prejudice against Christians seems to be the last socially acceptable prejudice in Europe' (Doc. 3). Of nine recommendations (Rs), four concern religion in general, three concern religion in general and (implicitly) the Christian faith in particular, and two concern Christian relations with minority religions and (among others or implicitly) Islam in a Christian majority context.

Religion in general. To act against harm, disrespect or contempt toward religion $\left(\mathrm{R}_{\mathrm{I}}\right)$. In the Statement we read in this regard:

the State might influence negatively and indirectly on individuals and communities, through a public and official message, or subtle actions, according to which religion appears a "remnant of ancient times", an "oldfashioned behaviour", something "inconsistent with progress and freedom" or the equivalent of "intolerance and violence".

$\mathrm{R}_{2}$ : To recognise freedom of religion as an essential dimension of humankind. The Statement reads in this regard: '[ $\mathrm{f}$ ]reedom of religion deals with the utmost profound and meaningful dimension of the human being. It presupposes transcendence. Therefore freedom of religion should occupy a preferred position among human rights and freedoms and not be considered as inferior.' $\mathrm{R}_{3}$ : To recognize the specific aspects of freedom of religion in comparison to related but different freedoms, like freedom of thought, speech, association or assembly.

Religion in general, (implicitly) based on specific consequences for the Christian faith in particular. Some light can be shed on the three recommendations concerned by the following passage in the Statement:

[Freedom of religion] deals with duties and relationships in human interrelations. That is why religious freedom involves an immunity sphere in which the State is not competent at all in order to dictate or govern citizens' options and decisions, as long as the religion respects the public order and the principles of the constitutional framework. 
In this regard, "States must recognise religious conscientious objection in delicate fields, like bioethics (abortion, euthanasia, stem cell research, etc.), education, military service, etc." Following this, R6 reads: "to pay specific attention to the right of religious conscientious objection in all social and public spheres" and also advocates "the right of parents or tutors to the moral education of children in public education".

Expressed in the same 'package' $\mathrm{R} 8$ reads: " $\mathrm{t}$ ] o recognise and protect the use and display in private and public of religious symbols". More precisely, in this regard we read in Doc. 2 (Platform Christianophobia in Europe): "we urge for a wide protection of religious symbols and traditions including Christmas trees and the wearing of religious symbols, such as crosses on necklaces (...)”. Finally $\mathrm{R}_{9}$ reads: "To recognise and protect freedom of speech on moral issues affecting public life".

As we will see later, this is related to the issue of hate speech legislation concerning homophobia, as was illustrated by the cases reported by the Alliance Defence Fund during the debates (pastors prosecuted in Sweden for homophobic hate speech following sermons during Mass addressing the issue of homosexual orientation as a sin).

Relation to minority religions and (among others or implicitly) Islam in a Christian majority context. $\mathrm{R}_{4}$ reads:

to guarantee the availability of places of worship taking into account urban planning considerations, and the artistic, cultural, religious, architectural and environmental characteristics of the territory. A dialogue should be established with the local community and religions traditionally present in the area. Legislative regulations should distinguish between places used for worship only and places of worship used for activities beyond purpose of worship $\left(\mathrm{R}_{4}\right)$.

We can find complementary elements to this recommendation in the Statement, although not specifically about places of worship, but concerning growing religious diversity:

many $(. .$.$) countries face a new challenge in which the complexities of$ religious pluralism have increased enormously. For these countries OSCE Commitments always offer a plain and general source for dealing with new problems and issues. It is important in this vein to be open-minded to peoples and cultures coming from other geographical areas, to grant 
full enjoyment of freedom of religion to those citizens who belong to new religious minorities and to trust in the centrality of the human person without surrendering their legal systems and politics to possible tension between cultures and civilisations.

This is an implicit - but clear - reference to Islam and Sharia law. Another issue is: 'to respect, with regard to anti-discrimination laws, the right to autonomy of religious communities and religiously inspired institutions' $\left(\mathrm{R}_{7}\right)$. In this regard we read in the Statement: "States cannot apply anti-discrimination law to religious communities and religiously-inspired institutions as if they were secular entities or part of State agencies." In the debates the case of Catholic adoption agencies which had to close because of their refusal to entrust children to homosexual couples was raised, as well as the case of a Christian organization legally obliged not to refuse to recruit non-Christian (in this case Muslim) personnel.

As stated above, the above-mentioned 'Defence of Western civilization' organizations were invited to sign up to the Statement, but abstained from doing so, for the reasons that we will review below. How do these organizations present themselves?

The Citizens' Movement Pax Europa (Bürgerbewegung Pax Europa - hereafter BPE) is based in Austria and has local chapters in several German Länder such as Baden-Württemberg, Bavaria, Hesse, NorthRhine-Westphalia and Rhineland Palatinate. It defines itself in its leaflet (Doc. 8) as a 'Human Rights Organization for Freedom and Democracy Against Islamisation' - an 'independent, nonpartisan movement', whose objectives "are to protect not only the democratic, free and secular rule of law in our country but also to struggle for European culture based on the Judeo-Christian traditions and - especially - on the values of the Enlightenment". Like the SIOE movement, this organization emphasizes that it "clearly distances itself from all right-wing or left-wing extremists and all xenophobic movements".

The organization puts forward some contextual elements regarding the 'host society' part of the issue (Doc. 8): "[d] ue to the rising threats being imposed by the Islamisation of Europe, we clearly explain and express these threats which are a given. We keep people informed about how Islamisation challenges, threatens and undermines our free and democratic order." In particular, "politicians, lawyers, clerics and journalists have to acquire authentic knowledge about Islam, about the Koran and the Sunna. They should be ready for free and politically incorrect public discussions about Islam - and about what Islam really means: 
SUBMISSION - rather than finding excuses or glossing over. Appeasement has never been a good idea."

The sense of SIOE-like duty with regard to future generations is reflected in BPE's recommendations which are addressed to the OSCE "in order to leave behind to our children and grandchildren a world in peace" (Doc. 4) In the report written by BPE's representative (Doc. 5), we also read this line: “[o]ne day in a distant future we might perhaps say: The OSCE brought Communism to an end; the OSCE also brought to an end the Islamic claim to domination."

The organization also supplies some contextual elements regarding the 'migrant' part of the issue: '[a]pproximately ten percent of Muslims in Germany are members of one of the four largest organizations (DITIB, ZMD, Islamrat, VIKZ)', whose objectives are said to be the implementation of 'a theocratic Islamic state in Germany'.

BPE's leaflet (Doc. 8) also says some words about Mission Europa - Netzwerk Karl Martell (a clear reference to the battle of Poitiers, 732), which was founded in 2007 "in order to coordinate organizations working against Islamisation". It is a Vienna-based organization whose objective is to make public - at international level - "what Austrians experience with the extensive Muslim presence". On the one hand, its populist-sounding slogan is 'Giving the silent majority a loud voice'. On the other hand, once again, here the public still would not know 'about the real Islam' and the organization's aim is "to put the facts on the table". It warns against Muslim groups' propaganda about Austria’s law on Islam as "the ideal way to integrate Islam into a country" (this law was the first in Western Europe to recognize Islam as a religion with an official status alongside the traditional Christian denominations; it was adopted on the heels of the Austro-Hungarian Empire's annexation of Bosnia-Herzegovina). It opposes Turkey's accession to the EU on the grounds of the "incompatibility of Turkey with western standards and life style". Also the two Ottoman sieges of 1529 and 1683 against Vienna are depicted as proof of Turkey's aggressive intention. Mission Europa is affiliated with the Wiener Akademikerbund (Vienna Association of Academics).

The Wiener Akademikerbund shares sensitivities close to those of the Christian organizations (e.g. the fight against attempts to abolish the technical terms of the Gregorian Calendar BC and $\mathrm{AD}$, which would be "a severe and totally unacceptable form of persecution of Christians and Christian belief”; see Doc. 2). This organization also seems to share a common element with the 'Defence of Western civilization' organizations concerning the general suspicion affecting Muslims as mentioned before, as it recommends "to the OSCE member states 
and OSCE institutions to protect the freedom of belief of only those religious groups that have made public all elements of their creed" (Doc. 2).

The International Civil Liberties Alliance (ICLA) presents itself as "an international alliance defending democracy and freedom". During the meeting the ICLA's representative circulated a document entitled 'A Proposed Charter of Muslim Understanding', written by ex-Muslim Islamic scientist Sam Solomon (Doc. 7). This document which ICLA recommends the OSCE to adopt 'in [its] entirety' (Doc. 6), invites Muslims, in particular Muslim leaders and representatives of organizations representing the Islamic faith, to adhere to a series of principles and attitudes: the rejection of violence in the name of religion; the recognition of equality between all human beings, including between man and woman; the right to religious freedom including the right to change religion; the precedence of national law over Sharia; full co-operation with the police and intelligence services in the fight against terrorism; the revision or reinterpretation of Koranic verses calling for violence against enemies of Islam, unbelievers or non-Muslim believers ( 17 specific Koranic verses are referred to as examples); adhesion to the UN Universal Declaration of Human Rights (1948) - ten articles followed by a form that can be signed on a named individual basis or in the name of an organization representing the Islamic faith and sent to a postal address in London. "This Charter, signed and adhered to, would guarantee the compatibility of Islamic organisations with secular democracy", says the ICLA (Doc. 6), mirroring the general suspicion affecting Muslims as mentioned before.

Let us now expound on why these organizations did not rally behind the Joint Statement. "There are in it some acceptable points; but also some passages that fully contradict our point of view, are therefore highly problematic, even if well intended", reports BPE's delegate Elisabeth Sabaditsch-Wolff. She mentions the following passage of the Statement, which "is totally unacceptable":

Governments must admit religious attire even in public places, except when paramount interests such as safety, public order or health compel to rule otherwise. Governments must recognise the wide extent and implications of the right of parents to the moral and religious upbringing of children, without any interference from political power and from official ideology leading to indoctrination. In sum, States must recognise religion as a vital source of moral behaviour which is beyond and superior to secular legal systems. 
Concerning first what BPE's representative sees as the 'unlimited right of parents to the moral and religious upbringing of their children', this would:

open the door to Islamic Madrassas, that are generally well known to prepare the ground for brainwashing and religious indoctrination. The intention that only parents should determine their children's moral education may be honourable in itself, but Muslim parents should first of all take some distance from the problematic verses and suras present in the Koran. [and a reference is made to the 'Charter for Muslim Understanding' (Doc. 5)]

A second objection concerns national (also meaning secular) law (cf. Doc. 4) and is in line with BPE's recommendations addressed to the OSCE meeting: "no religious laws of any sort be implemented into any national legislation" (Doc. 2), which is more specifically oriented towards Islam in its leaflet (Doc. 8): "No introduction of any parts of Sharia law into German (European) law which explicitly refer to Allah, Mohammed, and Islamic traditions".

We have here a rejoinder by the ICLA, that, referring to 85 operational Sharia courts in Great Britain, indicates "the possible misuse of religious autonomy to establish parallel societies where national law does not apply" - a misuse of religious autonomy which would threaten fundamental rights, in particular women's rights (cf. Doc. 6, entitled 'The problem of granting autonomy to Islamic enclaves in the West').

Conversely, BPE's representative mentions that the passage of the Joint Statement of (Christian) NGOs concerning places of worship for minority religions might have been supported (Doc. 5). This is in line with BPE's own recommendations addressed to the OSCE meeting (presumably linking with the suggestion referred to in the NGOs' Statement of a dialogue between "the local community and religions traditionally present in the area"): "We recommend that religious building projects not be enforced against the residents' appeals." Also probably in line with this, see the following position of the BPE (Doc. 8): 'abandonment of Islamic symbols of power or Islamic predominance' - a probable reference to minarets.

Before elaborating on some perspectives of understanding of the dynamics of the case under study, a complementary issue which is not addressed in the Joint Statement of NGOs but which is present in other documents related to the Vienna meeting and in the debates held on that occasion is worth mentioning: hate speech legislation and freedom of expression. In BPE's recommendations 
addressed to the OSCE meeting (Doc. 4) we read: "since criticism of religion is part of free speech, any effort to ban free speech, in name of religious interests on the pretext of 'Islamophobia' or racism must be prevented". In this line its delegate also said during the meeting: "hate speech is punishable, but criticism of religion is not hate speech and should be legal; there is a misuse of hate speech law to forbid criticism of religion". An element of observation worth noting in this regard is the clashes that occurred during the Vienna meeting between these organizations (ICLA in particular) and the anti-racist organization Conseil de la Jeunesse pluriculturelle (COJEP) International (originally founded by French youngsters of Turkish origin), which considered that the 'Charter of Muslim Understanding' that was circulated was an unacceptable manifestation of Islamophobia.

How is it from the perspective of Christian organizations? In Platform Christianophobia in Europe's recommendations (Doc. 2) we read:

Radical political correctness and hate speech legislation may lead to a restriction of the freedom of religion as well as the freedom of expression. We urge not to promote a claimed right not to feel offended which ends up in restricting the freedom of expression of individuals and groups, including religious individuals and groups.

One cannot but read the second part of the position expressed here as obviously referring to Islamophobia; if this were not the case, how could we understand this organization's adoption of recommendation No I (Doc. I) calling for action against harm, disrespect or contempt to religion?

\section{Some perspectives of understanding}

The phenomenon under scrutiny proceeds from a deep identity crisis for the actors concerned and can be understood - from their points of view - as a cultural and/or religious defence mechanism. While it claims to be non-racist, one cannot but question its perhaps unintentional xenophobic dimension. This issue is related to that of misinformation vs. manipulation, among others, in terms of demographic 'threat'. Let us go through these points before concluding our case-study as an example of a problematic advocacy coalition and saying some words about the extent of the phenomenon. 


\section{Identity crisis}

The two types of actors observed experience identity crises. The Christian organizations face a strongly secularized Europe, a decline in Christianity (at least in its traditional patterns - practice, relation to clerical authorities ...) and, at the same time, stronger religious and cultural diversity - with Islam at the forefront. They see themselves as an oppressed majority and have at the same time the feeling of becoming a minority, not only by comparison with communities of foreign origin, but also within the 'host part' of society. These Christians, as practising believers of conservative orientation, see new legislation (such as on abortion, euthanasia, same-sex marriage ...) harming their religious convictions in a mainstream secularized society that is at ease with - or even in favour of these changes. The call for the fight against attacks on majority religion in fact concerns majority religion as the religion traditionally present on the territory, not necessarily the effective majority religion as it has evolved.

They face the following paradox: a more secularized context tends to sideline the Christian religion (symbols, names of religious feasts ...) in the public space, while, at the same time, anti-discrimination laws made for minorities may provide for a certain protection and allow for more expression in this regard. So, for instance, the case of a Christian employee of British Airways asked to hide her crucifix necklace, while Muslim colleagues may wear a veil and Sikh colleagues may wear a Kara bangle (The Christian Institute 2009: 49). So while minorities may in some instances enjoy some protection (in other instances they of course also suffer from discrimination), the 'majority' lacks safeguards because of its status as the traditional majority religion. In this context Christian actors have succeeded in putting Christianophobia on the political agenda next to anti-Semitism and Islamophobia. Furthermore, in a situation where one cannot oppose the prevailing democratically adopted legislation, the only way is to live with 'conscientious objection' on an individual basis or try to obtain exemptions at a community level.

The 'Defence of Western civilization' actors are mostly motivated to protect the secular liberal democratic order, which would be threatened by Islamization. They also share the concern of Christian organizations for Christianity mainly as culture at the collective level, and not so much as faith at the individual and community level; religion as faith is in their view mostly a private issue (see Harry's essay in this book on the case of the Norwegian Progress Party (FrP)'s process of ideological repositioning in terms of both secular and Christian values). Both types of actors face a 'cultural relativism' that has its origins in the 
challenges resulting from the growing diversity of 'outsiders' or 'newcomers' in today's plural and pluralist societies. Some Christian actors face a secondary 'cultural relativism' that comes from 'within' - a phenomenon of unprecedented changes in values and moral standards within the inner culture itself, which are difficult for conservative people to accept.

Girardet (1986) puts forward the proposition that times of crises - I would add: in particular identity crises - are conducive to conspiracy theories. Matt Carr (2006: II) states that 'the fear of cultural and racial extinction has a long pedigree in European history', and evokes a parallel between between the 'Eurabia' conspiracy and the alleged Jewish conspiracy at the end of the $19^{\text {th }}$ century in Victorian Britain. Schiffer and Wagner (20II) also compare Anti-Semitism and Islamophobia in terms of 'new enemies, old patterns'. Looking for a scapegoat is a classical social phenomenon aimed at identifying the 'guilty one' who is at the root of the crisis and thus allows us to recover our sense of control in the world. At the same time, as we have seen, for some actors there is no deliberate conspiracy; they nevertheless share the same uncomfortable feeling of change in societies marked by growing diversity, relativism and the lack of points of reference.

\section{Racist or non-racist? Misinformed or manipulative?}

As we have seen, our actors claim to be non-racist. I see two possibilities here. Some actors may be sincere in this, but my considered view is nevertheless that both their monolithic and essentialized representation of Islam and Muslims and their alarmist, catastrophist, apocalyptic representation of European Muslim demography are not scientifically grounded (cf. infra). The same applies to issues like sharia courts (see Legrand 2008) in a Western context - an issue that Nimni tackles in this book from a contrasting, stimulating and sophisticated academic perspective. Other actors are more manipulative and their mobilization is nothing more than a more sophisticated form of xenophobia: a re-definition of an anti-migrant position in non-racist terms (Roy 2005). So, there is the example of a member of the French Bloc identitaire, who explains that campaigns targeting Islam are mainly for 'publicity purposes' for the movement:

There is no islamization of Europe, there are not millions of white people converting to islam either; it is still very much an immigrant phenomenon. (...) There is no phenomenon of islamization, but, on the contrary, there is a phenomenon of population replacement (Fourest 2012). 
I relate the two possibilities (racist vs. 'non-racist') to the distinction I make between first-level 'primary' Islamophobia and second-level political Islamophobia (Legrand 2010). The 'primary' psycho(-socio)logical meaning of Islamophobia is fear of 'Islam', nurtured by a series of empirical facts at both local and international levels; the media presentation of which is open to criticism. While the facts presented are indeed true (for example, reprehensible intolerant or hate speech - or speech advocating conquest - as made by some imams), their selectiveness leads to a confusing mixture and misleading generalizations about Muslims and 'Islam' 'as a whole'. Islamophobia - political Islamophobia this time - then steps in and exploits this fear around the presence and affirmation of 'Islam' in formulating an ideological agenda for the defence of Christian or Western civilization, which is supposedly under threat (Christianity in the strict sense, or secularized Christendom in more overtly political and cultural terms). The step from phobia as fear to phobia as hatred is not far.

Here now comes the delicate issue of criticism of Islam, freedom of expression and hate speech. Can religion be criticized whilst respecting religious beliefs? Where do you draw the line between legitimate criticism of a religion and hate speech directed at a community of faith or a group of individuals that belong to it? While the Danish cartoons targeted Islam, many Muslims on their part felt that they were stigmatized, and that they were all lumped together with terrorists in the aftermath of II September. There are no easy answers to this question. As Prof. Ombretta Fumagalli Carulli (Catholic University of the Sacred Heart, Milan) said as a keynote speaker at the opening session of the OSCE meeting in Vienna of July 2009, if 'a supposed right "not to feel offended"' ought not to be promoted, 'conversely - the freedom of expression' ought not to be 'abused to offend and vilify the religions, their representatives, symbols and teachings'.

\section{The demographic 'threat'}

In some localities in Europe (some towns or parts of towns), the concentration of the Muslim population nourishes fears of Muslims becoming a majority. The problem is that some local situations, which are real, are then - without any grounds - pointed to as a prefiguration of future situations at the national or European level, some activists putting forward the view that Europe will have a Muslim majority in a few decades. If we take the capital of Belgium as an example, Muslims are estimated to be $17 \%$ (Torrekens 2007: 2) or around 25\% (Dassetto, 2OII: 2I-25) of the total population, but they are only $4 \%$ at the national level. If we go into even more detail, $75 \%$ of Brussels' Muslim population is concentrated 
in only 5 of the 19 municipalities composing the capital (Torrekens 2007: 3). In Schaerbeek, the Muslim population (people originating from Muslim majority countries as well as their descendants having obtained Belgian nationality) comprise $29 \%$ of the total population (Torrekens 2009: 17). Scientific studies like the one published by the Pew Research Centre's Forum on Religion \& Public Life (20II) show that at national level in 2030 only two countries in Western Europe (Belgium and France) will have Muslims as little more than Io\% of their population (all the other countries remaining below 10\%, most between 5 and IO\% at national level).

\section{The case of a problematic advocacy coalition}

The situation that I have observed can be described by the following triangle. We could add other actors such as, for instance, feminist or Zionist/ Jewish/Israeli actors. As Liz Fekete (20II: 30 \& 42) rightly puts it, some (not all) Islamophobic actors who are, ironically, linked to anti-Semitic traditions have now, because of their fear of Islam and Arab countries, become staunch defenders of Israel and Zionism'.

Secularist / 'Defence of Western civilisation' actors

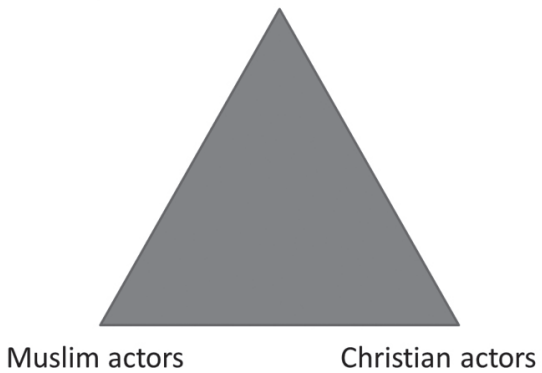

Let us observe dyadic relations within this triangle. Interaction between Muslim actors and secularist/'Western defence civilization' actors against Christians is improbable and was not observed. A Christian-Muslim dyadic alliance against 'Defence of Western civilization' actors was not observed (from observation in other settings I can state that this kind of configuration can take place to a certain degree, vis-à-vis secularist actors of the other type mentioned above - secular humanists). The observed dyadic alliance in our Vienna OSCE setting is that between Christian actors and 'Defence of Western civilization' actors around the issue of Islam and Muslims. This (tentative) advocacy coalition is, as we have seen, not without its tensions. The 'anti-islamization' activists who declare themselves 
to be non-racist then claim the right to criticize Islam without being accused of Islamophobia (conceived as racism directed against Muslims). For them it is not hatred, and there cannot be such a 'right not to be offended' which would open the door to muzzling free speech, which is part of secular liberal values. Here 'anti-islamization' Christian actors may not feel comfortable, because of their sensitivity to blasphemy or to the critique of religion in general: if doors are more open to a critique of religion, this could be of concern not only to Islam, but also to Christianity. Now one last word on the extent of the phenomenon.

\section{Conclusion: some insights on the extent of the phenomenon}

Is 'anti-islamization' activism a social movement? It has the ambition to be one. What we have is activists and groups of activists in national and transnational networks that are sufficiently structured, widespread and with a critical mass to qualify - at the very least - as an emerging social movement. Some are linked to parties, emanate from a party or are embryos of future parties. Their worldviews may spread, in particular through right-wing populist and 'nativist' parties (Weis 20II: 52-58), which are potentially more popular than extreme right-wing parties, and become more and more mainstream. All this in a general context marked by a less overtly Islamophobic secular liberalist public discourse that is far more likely to go unnoticed or unrecognized in comparison to its far-right 'version', as Allen argues in his essay on Islamophobia and the crises of Europe's multiculturalism in this book - as well, I would add, as to its right-wing populist and 'nativist' 'versions'. On the Christian side the Roman Catholic Church is herself well aware of the dangers present in her own ranks (Legrand and Vella Gauci 20II). Contrary to 'Defence of Western civilization' organizations, the actions of Christian organizations observed in this study cannot be qualified as a social movement; they remain at the stage of advocacy groups.

In the final analysis I would say that it is the 'anti-islamization of Europe' phenomenon being studied - and more generally the prevailing Islamophobic climate prevailing in today's Western Europe - which may well be the real danger, and not the alleged and so-called 'islamization of Europe'. 


\section{Notes}

I I attended these meetings in my former capacity as adviser on interreligious affairs at the Commission of the Bishops' Conferences of the European Community (COMECE), which is the liaising body of the Roman Catholic Church at EU level. The meetings concerned are the 'Supplementary Human Dimension Meeting - Freedom of religion or belief' (Vienna, 09-IO July 2009) (cf. Legrand 2009a) and the 'Human Dimension Implementation Meeting' (Warsaw, 28 Sep.-09 Oct. 2009) (cf. Legrand 2009b).

2 The OSCE was created on I January 1995 to replace the Conference on Security and Cooperation in Europe (CSCE), which resulted from the signing of the Helsinki Final Act (1975), which, during the Cold War, defined security not only in politico-military and economic-environmental terms, but also in terms relating to the human dimension especially in terms of democracy, human rights and minority rights.

\section{References}

Carr, M. (2006). 'You are now entering Eurabia', Race \& Class, 48 (I): I-22.

The Christian Institute (2009). Marginalising Christians - Instances of Christians being sidelined in modern Britain. Newcastle upon Tyne: $82 \mathrm{p}$.

Dassetto, F. (dir.) (2011). L'iris et le croissant - Bruxelles et l'islam au défi de la co-inclusion. Louvain-la-Neuve: Presses universitaires de Louvain.

Fekete, L. (2011). 'The Muslim conspiracy theory and the Oslo massacre,' Race \& Class, 53 (3): 30-47.

Fourest, C. (2012). 'Les enragés de l'identité,' Documentary film ( 52 '). S.l.: Et la Suite... ! (Productions).

Girardet, R. (1986). Mythes et mythologies politiques. Paris: Seuil.

Gravers, A. (2011). 'Au Danemark, nous ne serons jamais des dhimmis !', in Cassem, P. and C. Tasin (dir.) I8 décembre 2010: Assises internationales sur l'islamisation de nos pays. Mérignac: Riposte laïque, I05-116.

Legrand, V. (2007). “'Stop Islamisation of Europe” demonstration in Brussels,' in September 2007', Europe Infos, $\mathrm{N}^{\circ} 98$, November: II.

Legrand, V. (2008). 'Sharia Law and European legal systems: the issues', Europe Infos, $\mathrm{N}^{\circ}{ }_{\mathrm{IIO}}$ November: II.

Legrand, V. (2009a). 'Religious freedom in the OSCE Area: From commitments to implementation,' Europe Infos, $\mathrm{N}^{\circ}{ }_{11}$ 9, September: 8-9.

Legrand, V. (2009b). 'Anti-Semitism, Islamophobia and Christianophobia: Hate crimes and hate speech on the agenda of the OSCE', Europe Infos, $\mathrm{N}^{\circ}{ }_{121}$, November: 4-5. 
Legrand, V. (2010). 'Religious freedom and the visibility of religious minorities in Europe: the Swiss vote on minarets,' Europe Infos, $\mathrm{N}^{\circ}{ }_{124}$, February: IO-II.

Legrand, V. and J. Vella Gauci (20II). 'Islam in Europe and Islamophobia- Meeting of the Council of European Bishops' Conferences (CCEE)', Europe Infos, $\mathrm{N}^{\circ}{ }_{14}$ I, September: 9-Io.

Marchand, R. (2011). 'Voilà comment l'islam nous mène la guerre, en France,' in Cassem, P. and C. Tasin (dir.) I8 décembre 2010: Assises internationales sur l'islamisation de nos pays. Mérignac: Riposte laïque, I43-150.

Pew Research Center's Forum on Religion \& Public Life (2011). The Future of the Muslim Global Population - Projections for 2010-2030. Washington DC: Pew Research Center.

Roy, O. (2005). La laïcité face à l'islam. Paris: Stock.

Schiffer, S. and C. Wagner (20II). 'Anti-Semitism and Islamophobia - new enemies, old patterns,' Race \& Class, 52 (3): 77-84.

Stadtkewitz, R. (20II). 'En Allemagne, notre nom est un programme, longue vie à notre liberté', in Cassem, P. and C. Tasin (dir.) I8 décembre 2010: Assises internationales sur l'islamisation de nos pays. Mérignac: Riposte laique, 16I-166.

Torrekens, C. (2009). L'islam à Bruxelles. Bruxelles: Ed. de l'Université de Bruxelles, 208 p.

Torrekens, C. (2007). 'Concentration des populations musulmanes et structuration de l'associatif musulman à Bruxelles,' Brussels Studies (5 mars) 4: 16 p.

Weis, C.R. (20II). L'"anti-islamisation" organisée en Europe occidentale et dans les pays scandinaves, après le II septembre 20II, Mémoire de Master en Sciences politiques (orientation générale). Louvain-la-Neuve: Université catholique de Louvain (UCL), septembre 20II, $82 \mathrm{p}$.

\section{Documents (case-study):}

I- Joint Statement of NGOs - Observatory for Religious Freedom (Spain), Observatorio para la libertad religiosa y de consciencia (Madrid), Alliance Defence Fund (USA), Paneuropa Union (Austria), Human Rights Platform www.christianophobia.eu (Europe) \& Evangelischer Aufbruch (Germany), OSCE Supplementary Human Dimension Meeting, Vienna, 9-10 July 2009

2- Civil Society Recommendations (listed by NGO), OSCE Supplementary Human Dimension Meeting on Freedom of Religion or Belief, Roundtable for Civil Society

3- Side Event www.christianophobia.eu, HDIM 2009, 5 October 2009

4- Citizens' Movement Pax Europa (BPE) Statement \& Recommendations, OSCE Supplementary Human Dimension Meeting on Freedom of Religion or Belief, Vienna, 9-10 July 2009 
5- Bericht vom Supplementary Human Dimension Meeting on Freedom of Religion or Belief, Wien, 9-Io July 2009, by BPE-Delegierte E.S.W.

6- International Civil Liberties Alliance (ICLA) (2009) 'The problem of granting autonomy to Islamic enclaves in the West,' Paper presented to the OSCE Supplementary Meeting on Freedom of Religion or Belief, Vienna, July 9-10

7- 'A Proposed Charter of Muslim Understanding' (2007) Sam Solomon, Revised ed. ( ${ }^{\text {st }}$ ed., December 2006), April, London: www.pilcrowpress.com/charter

8- BPE Bürgerbewegung Pax Europa - Citizens' Movement Pax Europa (leaflet)

9- ESW \& HF (sin anno), 'Freedom of Expression in Austria - Freedom of Speech in Austria', Working Paper. S.l.: s.e. 

CHAPTER 8

\title{
Discourses on Religion and Identity in Norway: Right-Wing Radicalism and Anti-Immigration Parties
}

\author{
Frédérique Harry
}

For the last twenty years, Europe has witnessed the birth of new extreme right-wing movements fighting for a stronger national identity, supporting islamophobic theses and sharing a strong dislike of immigration figures and policies. Little by little, anti-immigration parties have become leading forces in many countries and are now duly represented in numerous Parliaments (in Sweden, Denmark, Norway Finland, as well as in France, Greece, the Netherlands and so on). Vincent Legrand's work (see also in this book) depicts some of these new movements, including such organizations as 'Stop Islamization Of Europe' in Denmark, which share transnational networks and a common ideological foundation: they often quote Samuel P. Huntington, the creator of the clash of civilizations postulate; they frown upon cultural Marxism and fear the end of Europe as we know it - as a vigorous Muslim demography may threaten it as such, for instance (the latter being called the Eurabian thesis). Vincent Legrand's analysis highlights the way they give a wide berth to more 'typical' and/or older racist ideologies, all the while trying to redefine xenophobia in terms of conflicts utterly deprived of racial issues. With them, xenophobia and racism are actually evolving differently and reflect the broader mutations that are taking place in our societies. This evolution teaches us something crucial about the way European citizens understand and build their identities, as a novel social and political order gradually replaces nation states - the model formerly known to us as a means of European democratic governance - in what could be called a 'postnational constellation' (Habermas 2000). Therefore, in analysing Vincent Legrand's essay 
further, I shall focus on how the Norwegian right-wing radicalism and antiimmigration parties use religion (somewhat paradoxically) as a means to redefine collective identities in our more global, multicutural and interdependent societies. Whilst Europe is becoming highly secular - we will even use 'post-secular' to designate Northern Europe countries -, these movements have actually brought religion back into politics, a fact quite likely to betray its dichotomy with the most common theories about secularization.

Fully to understand how religion is used by far right parties to depict new patterns of 'imagined communities' (if one may use Benedict Anderson's expression), this study shall be based on the analysis of Fremskrittspartiet's party platforms, interviews, Anders Behring Breivik's famed manifesto 2083 , and electoral studies performed in 2001, 2005 and 2009 (courtesy of Statistics Norway). My personal hypothesis is that multiculturalism and the feeling of 'globality' (Giddens 1990) reactivate religion's collective function (Durkheim may have been close to this definition), as our societies tend to become more globalized and their identities more reflexive.

\section{Religion and nationalism in northern Europe societies}

Northern European countries are interesting, if not unique, case studies. They are constantly rated as the best places to live in the world, political and social unrest is rare, and theirs are among the healthiest economic systems in the world. Still, anti-immigration parties have become major political forces there, and they are now well represented in all northern Parliaments: the Norwegian Progress Party (Fremskrittspartiet - FrP) in the Storting, the Danish People Party (Dansk Folkeparti) in the Folketing, the True Finns (Perussuomalaiset) in theEduskunta, or even the smaller Sweden (or Swedish) Democrats (Sverigedemokraterna, admitted in the Riksdag in 20ro). All are sceptical about the multiculturalism which, in their opinion, undermines or even destroys European culture and national unity. There are also much more radical organizations and people, such as the one responsible for the grim Oslo attacks of 07/22/2011: Anders Behring Breivik killed 77 people, mostly young members of the Labour Party (Arbeiderpartiet), and planted a bomb in a car which detonated in Regjeringskvartalet, the executive government quarter of Oslo. This self-proclaimed lone wolf claimed that he wanted to take revenge on the Norwegian multicultural policies that he held the Labour Party responsible for. In his manifesto, 2083, Breivik made it 
clear that he fully despised such an intermingling of communities, Islam and its social-democratic 'cultural Marxism', relying on the 'Eurabian' thesis to support his vision of a Christian-European cohesive group at war against Islam and the Arabic world. Despite the information provided at first by the police, this man is far from being a fundamentalist Christian or 'an excessively religious man': rather - as he puts it - a 'supporter of a monocultural Christian Europe' (2083) who radically isolates political and cultural functions from ethical and metaphysical issues.

We may call northern European countries 'post-secular societies'; theirs are among the lowest rates of traditional religious observance in the world. Since World War II, religious ties and habits have declined. Religion has gradually been sidelined, as the separation between State and Church has asserted itself, and public institutions became more and more independent of the Church. Following high immigration waves and the development of mass pluralism, religion had to redefine its prerogatives. In Norway, the separation between State and Church (May 20I2 -2000 in Sweden) gave way to a later stage of secularization progress: multiculturalism and religious diversity are now the social norm. The institutions have expanded policies freed from denominational and/or spiritual justifications. Religion and the National Churches have lost their 'from above' prerogatives but still have a legitimate role to play as ethical and moral actors in public matters. In such a highly secular culture, religions are quite distinct from politics, since they no longer have any structural political function. Yet, paradoxically enough, the northern European peoples are still intimately linked to the cultural and 'tribal' function of their National Churches (Harry 2013; Petterson and Riis 1994; Riis 2013).

Interactions between nationalism and religion raise a lot of theoretical discussions (Brubaker 2012; Santiago 2012). The return of religious issues in politics, and especially among nationalist leaders and followers, questions the 'linear and compensatory' model, where nationalism is often viewed as a replacement for historical religions. However, even if this model may still seem relevant, the importance religion gains today in highly secular countries requires a deeper analysis of the function of religion in the political field: As elements of national collective representations, do religions assert the compensatory evolution? How do religions help to elaborate collective and fictitious identities in the midst of societies becoming more and more globalized and interconnected? 


\section{The memorialization of religion}

The $16^{\text {th }}$ century Lutheran Reformation in Scandinavia (and even more so throughout the $17^{\text {th }}$ century), based on the principle of cujus regio ejus religio ('Whose realm, his religion'), led to confessionalization (or 'confession-building') through the erection of religious states and involved the "fusion of politics and religion through the emergence of territorial churches subordinated to secular political control" (Brubaker 2012). Churches had a territorial and identitarian function and constructed their legitimacy in terms of collective identities acting as symbols of national unity. In this context, being a member of these Churches meant belonging to the national community they partly organized and ritualized (Aagedal 2000). Still, the de-territorialization which occurred during the $19^{\text {th }}$ and $20^{\text {th }}$ centuries gradually sapped the historical links between religion, citizenship and ethnicity.

More recently, throughout the second part of the $20^{\text {th }}$ century, Norway obviously turned into an attractive place to live: the number of immigrants grew steadily during the late nineties and after 2004, reaching $13.1 \%$ of the Norwegian population in 2012 (Statistics Norway). This led to a more extensive religious plurality and the development of faiths that were quite unknown before. Consequently, this situation radically changed the notions of multiculturalism, religious diversity and, last but not least, the conception of citizenship and identity. Today's angles may seem paradoxical, though: despite very high rates of secularization and quite affirmative multicultural policies, most Norwegians still belong to the Lutheran Church of Norway (77\% of the population in 2012, Statistics Norway). Religion still has a national and collective symbolic function, as the high rates of baptisms, religious wedding ceremonies, etc. attest to. The Church of Norway still owns cultural preemption over life and death rituals and assumes "cognitive, ideological, normative, commemorative and dramaturgical functions" (Riis 2010). Thus, Norway is a good example of a "belonging without believing" society (Davie 1994). Yet, in spite of wide secularization and an outward acceptance of diversity and religious pluralism, examinations demonstrate that religious pluralism and ethnic diversity can create suspicion. By and large, Norwegians consider immigration to be a positive aspect of society's growth, but contacts between natives and migrants have never incresed in numbers over the last ten years (from 200I to 2010, marriages between those two categories are even fewer - Statistics Norway: 20I2). Meanwhile, the Progress Party $(\operatorname{Fr} P)$, allied to the Conservative Party (Høyre, meaning "Right" - $[\mathrm{H}]$ ), 
became a major political formation and may even rise to power after the next election, on Sept. 9, 2013.

In this period, the $\operatorname{Fr} P$ leaders' speeches and platforms have increasingly been marked by religious references, evolving from a very critical position to a clear acknowledgement of Christianity as democracy and individual freedom's cultural matrix, as well as the Norwegian and Western cultures' matrix. Now, the $\operatorname{Fr} P$ is a "party for the people [whose] values are that of the Norwegian constitution, of the Norwegian and Western traditions: A cultural legacy inspired both by Christian and humanistic values". Later, they clarified their views, stating that "Christian culture and ethics [are the] fundamental values of the Norwegian society" (FrP party platform: 2005-2009). Yet, during the seventies and eighties, the $\operatorname{Fr} P$ was very critical, even sceptical, of Christianity and the Church Of Norway: In order to fight for more individual freedom from the traditional social order, the party wanted to ban catechism in public schools, wanted to reduce the Church's income and, last but not least, separate Church from State. The dominant denomination was seen as a threat to individuality and liberal freedom. But in 2008, as the debate about school law was becoming fact, the FrP made it clear that school teachings should be based upon humanist and Christian traditions and legacies (Harry 2006).

Nevertheless, $\operatorname{Fr} P$ supporters are among the less religious voters in Norway. Two accurate studies made about Norwegian voters after the parliamentary elections of 2001 and 2009 (Aardal, Valen, Karlsen and Normann 200I; Berglund, Reymert and Aardal 2009) show that they widely disapproved of the policies typically supported by Christian Norwegian parties in $200 \mathrm{I}$ (i.e. restrictive alcohol and smoking policies). To boot, $43 \%$ of the $F r P$ voters favoured abortion in cases when the infant might end up sick or disabled - the latter figure being the highest among all Norwegian parties. In $2009,65 \%$ of the $\operatorname{Fr} P$ voters considered themselves as being 'religiously passive' (6I\% in 1997 and 2001, 66\% in 2005), the next highest score after that of the Socialist Left Party (Sosialistisk Venstreparti-74\%). FrP supporters have no distinct religious behaviours and are among the most secular and passive. On the other hand, the range of $\operatorname{Fr} P$ advocates considered as 'religiously active' (the latter classification being based upon active membership of any given religious community) rose from $7 \%$ to I $4 \%$ over ten years (200I-2009). This fact may be viewed as coherent with the result of some studies concluding that xenophobic types pay more attention to religious affiliation as an obligation and an attachment to a certain form of moral spirituality, while the more tolerant view religion as a personal choice 
and preference, open to other religious traditions (Riis 20I0). In other words, $\operatorname{Fr} P$ voters are still among the less religious types, but they are more attracted to religious identity, and religious affiliates in their midst are growing in numbers. The clear discrepancy between traditional religious and moral values and the use of a vague religious identity are quite consistent with the view that former leader (1978-2006) Carl I. Hagen expressed in 2004: It is more important to promote fundamental Christian values in society than that everyone turns into a faithful Christian. Yet, despite the gap between traditional Norwegian values and the opinions supported by most $\operatorname{Fr} P$ voters, the party has now seized and polarized the general debate about religious identities in Norway. It is setting the tone and reinterpreting Christianity as a symbolic matrix for nationality and democracy, leading to secular humanism, gender equality and democratic values. Nothing new under the sun, the function attributed to religion focuses here on the role played by the legacy of identities due to the process of nation-building.

From this perspective, the memorial identity function in the FrP's speeches and platforms - and more generally in right-wing populism - is not on a par with a return of religion. Rather, it is a process of memorialization, as the notion of civil religion, a from-above structuring institution, departs more and more from the public sphere. It is more likely that this evolution is highlighting the final - or at least one further - step on the secularization process, where the nationalmemorial function works as a reminder of the past. All the same, it would be too simplistic to focus only on the memorial function as a reminder per se. It also plays a very discriminatory role when it separates the national/cultural community from supposedly allogeneic ones in a multipolar world.

\section{The essentialization of religion}

The globalization of economic, political (Norway is not part of the European Union but does belong to the Schengen and European Economic Areas), social and cultural relationships has important consequences on our perceptions of the world and its communities. Globalization and the greater accessibility of the media and of new means of communication challenge historical borders and traditional identities. The current multipolar situation and the European follow-up construction further challenge the supremacy of nation states. The "disembedding of social systems" - characterized by the dissociation between social relationships and local contexts of interaction -, as well as the development 
of a new interactivity in a dislocated time-and-space pattern (Giddens 1990) modify the definition of our identities as individuals and community members. The point here is not to discuss the way global mutations can concretely be measured, but merely to stress how we feel or perceive them. The sense of belonging is based not only upon definite rational and well recognizable frameworks, but also on the perceptions, beliefs and subjectivities which explain and organize (the cognitive function) and possess an affective and social function. The feeling of community happens to be both local and global, as the perception of being a part of a multi-layered, networked and geographically flexible world grows in intensity. Therefore, affections, feelings and emotions are "active ingredients" when it comes to defining new identities, even more so since the de-territorialization of religions in Europe has led to multicultural and reciprocal societies - shaped by constellated religious and ethnic communities. In this context, our rational understanding of electoral and political behaviours as well as platform narratives must then be reinforced by taking into account emotionality and subjectivity so as to comprehend and rebuild the subjective and imagined constellations we live in.

The FrP's speeches and platforms and, even more importantly, Breivik's manifesto view ethnic and religious identities as parts of an open and global world where religious identities are constellated into vague territorial entities. Here, religion is used to redefine borders, be it inside or outside national communities. Christianity serves as a transnational cultural segment destined to create a feeling of global sameness, allowing the exclusion of others in spite of a world open to all. There is no trace of theological or metaphysical to be found in those theories, just the self-same postulate according to which secular Christianity created a habitus of democracy, equality and liberalism. They evidently target Islam, the essence of which becomes viewed as irreconcilable with European culture - since Christianity is, in their opinion, the matrix in which the idea of Europe has its roots - and state an intrinsic impossibility for Islam and Muslims to promote democracy, gender equality and human rights. Per se, Islam is allogeneic to Norway and Europe. To illustrate this notion, let us quote former FrP leader Carl I. Hagen: In 2004, while visiting a Charismatic Parish in Norway, he publicly declaimed that the prophet Muhammad may never have said: "Let the little children come to me" (Matt. 19:14) unless, he added, he intended to use them to become soldiers for the Jihad. If one puts his political strategy aside, and considers that right-wing radicals and anti-immigration parties teach us something about the transformation of religious identities, the essentialist understanding of 
religious consciousness in politics highlights a phenomenon some believed would disappear with modernity: religion rears its head as a collective identity marker even among non-religious people, so as to redefine borders in this new 'postnational constellation' (Habermas 2000). It defines groups according to their religious identities and presents them as homogenous entities. In actuality, it is a mirror-like process based on the perception that Muslims form a homogenous cultural community. Consequently, it leads to the perception of a European Christian common and harmonious identity, although euroscepticism rates high among FrP supporters.

\section{Conclusion}

Is the presence of religion in right-wing Norwegian politics no more than a cultural anachronism, or - quite the contrary - is this proximity the dawn of a larger swing? The "memorialization" of religion seemingly rests upon the national function formerly allotted to the Church. Yet, strikingly enough, this memorialization process occurs when the historical role of the Church dwindles. On the contrary, the 'essentialization' of religion seems to be a highly actual process. Communities are reduced to essentialist features as they become more and more dislocated from time and space, while religious identities are reduced to simplistic cultural codes and goods to support the thesis stating that the differences between Christianity and Islam as cultural and political matrices are insuperable. Breivik's manifesto seems much more radical than the FrP's platform or speeches, but is very close when he claims for "a European cultural conservative hegemony in Europe" and a "Church leadership who supports a future Crusade with the intention of liberating the Balkans, Anatolia and creating three Christian states in the Middle East" (in 2083), matching the perception according to which groups do exist throughout pluralized and globalized societies. Hence, the ethnic dimension of religion in right-wing politics seems to be progressively complemented by an essentialist/discriminative function more adeptly conform to the growing feeling of globality and the development of a non-racist transnational xenophobia. Ethno-differentialist narratives replace the racialist thesis by considering secularized Christianity as the matrix of the habitus of democracy, gender equality and freedom versus the fantasized habitus of dictatorship, inequality and totalitarism that Islam is held responsible for - emphasizing consequently the importance of religious identities even in highly secular times. 


\section{References}

Aagedal, O. (2000). 'Den nasjonale dimensjonen i Den norske kyrkja,' in Sørbye Liv, Norske virkeligheter - diakonale utfordringer: Io år med Diaforsk, Oslo: Tapir, pp. I09-I44.

Aagedal, O. and B. Seland (2008).Vekkelsesvind, dennorske vekkingskristendom. Oslo: Samlaget.

Aardal, B., Valen, H., Karlsen, R., Kleven Ø., and T.M. Normann (200I). Valgundersøkelsen 200I, Oslo-Kongsvinger: Statistisk Sentralbyrå.

Anderson, B. (1983), Imagined Communities: Reflections on the Origin and Spread of Nationalism. London: Verso.

Bastian, J.-P., Champion, F. and K. Rousselet (200I). La globalisation du religieux. Paris: L'Harmattan.

Berglund, F., Reymert, I.S. and B. Aardal (2009). Valgundersøkelse. Oslo-Kongsvinger: Statistisk Sentralbyrå.

Blom, S. (2011). Holdninger til innvandrere og innvandring. Oslo-Kongsvinger: Statistisk Sentralbyrå.

Brekke, T. (2002). Gud i norsk politikk - religion og politisk makt. Oslo: Pax Forlag.

Brubaker, R. (2012). 'Religion and nationalism: four approaches', Nations and Nationalism I8 (I): $2-20$.

Camus, J.-Y. (éd.) (1998). Les extrémismes en Europe. La Tour d'Aigues: Editions de l'Aube.

Gauchet, M. (1998). La religion dans la démocratie. Parcours de la laïcité, Paris, Gallimard: Le Débat.

Gauchet, M. (2004). Un Monde désenchanté?, Paris: Editions de l'Atelier.

Giddens, A. (1991). Modernity and Self-Identity, Self and Society in the Late Modern Age. Cambridge: Polity Press.

Giddens, A. (1990). The Consequences of Modernity. Cambridge: Polity Press.

Habermas, J. (2000). Après l'État-nation. Une nouvelle constellation politique. Paris: Fayard.

Harry, F. (2006). La dimension religieuse dans les partis nationalistes conservateurs norvégiens (200I-2006). Paris: Paris-Sorbonne (master thesis).

Harry, F. (2013). 'Crise du religieux, crise des représentations. La révolution séculière des réveils scandinaves,' in Arnaud, A., Harry F., Mareuge, A. and B. Terrisse (eds.). Identité(s) en crise: langage, discours et représentations. Le texte et l'idée, Nancy, to be published.

Hervieu-Léger, D. and G. Davie (eds.) (1996). Identités religieuses en Europe. Paris: La Découverte.

Hervieu-Léger, D. (1999). Le pèlerin et le converti. Paris: Flammarion.

Hobsbawn, E. (1992). Nations et nationalismes depuis 1780: programmes, mythe et réalité. Paris: Gallimard.

Ivaldi, G. (2004). Droites populistes et extrêmes en Europe occidentale. La Documentation française, Collection « Les Etudes ». 
Lambert, Y. (2000). 'Religion, modernité, ultramodernité: une analyse en terme de « tournant axial,' Archives de sciences sociales des religions, I09: 87-116.

Petterson, T. and O. Riis (1994). Scandinavian Values: Religion and Morality in the Nordic Countries. Uppsala: Acta Universitatis Upsaliensis.

Riis, O. and L. Woodhead (2010). A sociology of religious emotion. Oxford: Oxford University Press.

Riis, O. (2008). 'Le dilemme nordique', in Capelle-Pogacean A., Michel, P. and E. Pace (2008), Religion(s) et identité(s) en Europe: L’épreuve du pluriel. Paris: Presses de Sciences Po « Académique ».

Riis, O. (2013). 'Religion in Scandinavia at the beginning of the $2 \mathrm{I}^{\text {st }}$ century', Deshima, Strasbourg, to be published.

Rublack, H.C. (ed.) (1992). Die lutherische Konfessionalisierung. Gütersloh: Gütersloher Verlagshaus.

Santiago, J. (2012). 'Secularisation and nationalism: a critical review', Social Compass 59 (I): 3-2I.

Thorkildsen, D. (1995). Nasjonalitet, identitet og moral. Oslo: Norges forskningsråd. 


\title{
CHAPTER 9 \\ Competing Forms of Identity and the Concept of Sovereignty in Europe
}

\author{
Murat Sevencan
}

Though a person may carry more than one group identity within the layers of self-perception, the effect of it upon his/her choices and decisions depends mostly on the salience of belongingness for that person. Moreover this salience is continuously and indefinitely challenged by other possible and present group identities. Along with the putting on and off the membership hat game, the national identity is not excluded either.

Even if in recent years, nationalism has been on the rise in Europe, it may be interpreted as a reaction to the decline in salience of national identity within the community of social belonging. If one takes this interpretation as a basis, then one must ask some closely related questions on the subject, such as: "What is challenging the salience of national identity?" and "Will such challenging of the salience of national identity be evenly successful if the people are concerned by the perception of international issues?" The purpose of this chapter is to search for the five foreseeable answers to these questions in theory and quantitative data. World Values Survey Data will be used for the quantitative reasoning.

\section{Introduction}

Being more of a political hat, national identity fastens, or glues, a person to a family which sometimes consists of more than a billion members, which would be presented as imagined. As Anderson puts it, this family "is imagined because 
the members of even the smallest nation will never know most of their fellowmembers, meet them, or even hear of them, yet in the minds of each lives the image of their communion" (1991: 6).

Because of the stated imaginedness of this identity category, the effect of belonging, or rather mobilizing the power of it, would be dependable only if this so-called illusion were alive in the mind of a person convinced by it. From the rather recent history of nation building, despite the primordial connectedness assertions, one can assert that national identity bloomed over the mould of old identities, as a sovereignty transfer. This transformation of identity was from one that binds the person as the subject of God, or Godly sent patronage, to one that appoints the person as a citizen in charge of the maintenance and enjoyment of the homeland. Although this joyful duty seems to be accepted as natural, the theoretical model states that a national identity is reproduced through central education as a voice of other family members, and the state power of imposition is presented as a fatherly or as 'uncle's' advice, and sometimes its violence as father's belt. But although the classical paradigm of International Relations (IR) takes the nation-state as the single actor of the anarchic jungle of states, national citizenship has never been a unique identity in the mind of a person in his/her actions. As long as the modern paradigm continued, not the men's but the citizen's aspect of a person is taken in consideration to construct a national identity in state level affairs. However, what about the other layers of self-perception in their relation to the national identity?

\section{Identity and transfer of sovereignty}

One can argue that national identity, as a modern concept, is constructed and sustained through tools of the modern world for each new member of society. These are the standardized education of society, which must include national understanding of history on the primordial view of nationhood; social support or priority grant for certain values of the society, with the help of society networks, such as certain branches of sport or the arts; law enforcement regulating certain parts or functions of public life, such as the coordination and supervision of economic and legal processes; and lastly the use of certain rights on behalf of society, such as issuing a common currency, conscription.

These modern tools are not just the tools with which to use the sovereignty of the modern nation state, but also those shaping the national identity of each 
new member of society. But these tools forming the newcomer's national identity are challenged by the changes in the Westphalian System by both the delegation of sovereignty and the effect of globalization. In other words, one can state that with the level of democracy and desacralization of the state, especially in the post-WW II era, the non-citizen side of a person became an effective factor, particularly in daily politics. One can also observe that the nonpareil existence of the nation-state has also started to be challenged by old powers of the game, such as imperial, local and religious fronts. The accumulation of sovereignty from local lords, clergy and emperors to the kings of states has been reversed by a new invention of the post-war European populi, the European Union.

As we all know, the transfer of sovereignty started with the delegation of the rights regarding the coal and steel industry of the six member states to the ECSC by the 195I Treaty of Paris. Since the High Authority's power overrode the member states', the organization obtained its unique status of a hybrid case; it was neither an intergovernmental nor an economic cooperation, in which no authority can supersede the states' decisions, nor a federal state-like situation, due to its limitation on coal and steel sectors (Rittberger 2003: 210). Therefore it was called a sector-based federation. Although this phase of sovereignty delegation did not affect the national identities of the citizens of six, the further integration attempts started to bring both psychological and political shifts.

The first type of shift was faced with the foundation of the EEC by the 1957 Treaty of Rome. The European Court of Justice, as the highest court and the interpreter of the European treaties since 1951, started to affect the perception of social relations among the status groups of societies by reinterpreting the articles of the treaties while giving final decisions on cases. The reinterpretation of Article 7 of the Treaty of Rome, says: "Within the scope of application of this Treaty, and without prejudice to any special provisions contained therein, any discrimination on grounds of nationality shall be prohibited," as also the prohibition of discrimination of gender, on the basis of equal pay, or discriminating against citizens of non-member countries, who came as guestworkers onto EEC territory. Although these types of interventions may be taken as positive in the legal and social space of a nation, one should bear in mind that these types of extensions of the supra-national share of sovereignty will create increasingly stronger bonds with the supra-national power than the national one.

The second type of shift happens not because of an unapproved extension of sovereignty but is an extension through the limitation of room for manoeuvre for the nation state caused by harmonization. Nevertheless the effect of those 
harmonization acts is brought into sharp focus in the newer eastern members of the Union, but it can also be observed incrementally in the historical evolutionary process in the old members as well. It also finds a place in scholars' terminology as the transformative capacity of the Union (Tamás 200I: 6-8; Dyson and Featherstone 1996).

All these limitations on a state's share of sovereignty do not cause a direct shift in the national identity of the citizens, but they narrow the state's space for reaction to the changes in the international and intellectual environment for 'convincing' citizens to abide by the social contract signed between them and the state. Hence this can be called one of the indirect shifts.

The next type of shift springs from the empowerment not of a supra-national actor, but of the sub-national actors. As is declared in Article 5 of the 1992 Treaty of Maastricht, though it's put onto table with the 1985 European Charter of Local Self-Government, the principle of subsidiarity will be used in certain matters, which means simply leaving matters to the lowest level of government which we call the local authorities, due to their effectiveness and the ease of reaching tangible objectives efficiently. As is stated, or rather secured, in Article 9 of the same Treaty, the Union will continue to respect the state's sovereignty and most of the time that is what happened.

However, the principle of subsidiarity brought the local authorities more power and flexibility to function on behalf of the state. No one can insist on the diminishing power of the state's authority here, but because of project based funding, one can accept that, if not the control, the functions themselves have become more uniform through European patterning.

Lastly, not because of the EU, but the increasing interdependence and uncontrollable means of communication which we call globalization created another psychological and political shift in the national identities of Union citizens. This shift manifests itself as a uniformity of choices, language and terms, use of body language, and, most importantly, value orientations.

In conclusion, one can say that the sovereignty transfer of the EU states not only weakened their national sovereignty, but also the bond between their nationals and their capability to manoeuvre. Further, this weakening does not transfer these powers to a supra-national actor, but to sub-national actors, namely the local authorities. Figure I illustrates this by making an analogy with the feudal period. 


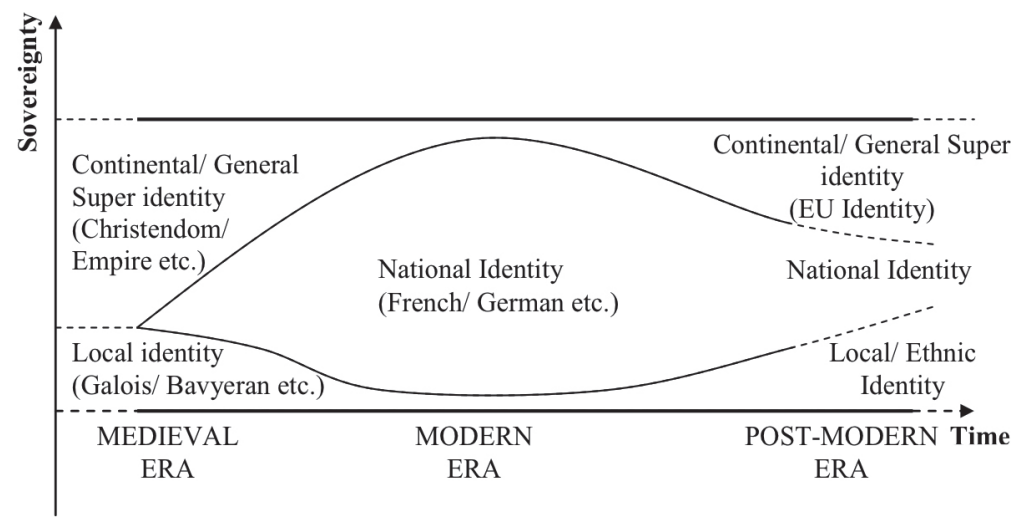

Figure I - Nation, EU and Local Identities on Transition to Post-Modern Era (Source: Sevencan, 2006, p. 284)

Especially with the further accepted subsidiary principle, the member-states are committing their sovereign rights to continental authority, which leases the use of it to local political entities. For example, the Italian Constitution of 1947 has a specific clause on the limitations of national sovereignty, and the Germans, in their constitution of 1949 , approved the transfer of powers to international organizations backing the ratification of the $\mathrm{EC}$ founding treaties. The Netherlands also changed their constitution with an amendment in 1953 to make it compatible with the transfer of their sovereignty in the coal industry through ECSC membership (Hoffmeister 2007: 62). This reverse flow has also supported another release of sovereignty to other international organizations, such as international courts. Hence, many things changed in the civitas so that even an indivisible concept such as sovereignty can be divided, or rather 'shared,' with other actors in the international arena, not by force but willingly as a "mutual limitation of sovereignty" (Habermas and Derrida 2003: 296). ${ }^{1}$

One can tell the story metaphorically with national identity as a mandatory single type of hat. When the dress code of public places is relaxed, individuals in the community see the melon hat, for example, as more and more of a choice amongst a spectrum of other hats. As a woman one may be feminist, or ethnic Scotch, or Christian or with a pious identity. But when that person is a Scottish lady who is a Roman Catholic and believes that the hat is not religion but manmade, the female's preference on political issues will be decided by her perception of 'good' and 'bad' in relation to her hat or, in socio-psychological terms, her salient identity. 
The purpose of this study is to analyse quantitatively the very existence of this multiple belongingness, that seems to surface politically, and the share of salience within the competing political identities. After the preliminary analysis of the competing identities, these identity types will be profiled by means of a quantitative analysis. During this analysis the World Values Survey (WVS) Databases will be used.

\section{Competing political identities}

At this point, for the purpose of the study one should seek the forms of identity which may compete with the national one. However the purpose of this search is not to find out how many different group identities there are, nor to find out the propria of possible identities, but rather how many different forms of identities one can count.

As one looks at the recent literature on European identities, one may find different approaches to the subject. Morozov and Rumelili model the European Identity from a constructivist point and define a continental identity with the help of others, such as Turkey and Russia. While defining this they create an elite, reactive and exclusive identity; they openly emphasize Europe's Christianity and post-industrial values as western ones (2012: 42-43). Burity, in his comparative review article, while commenting on the effect of globalization on identities takes an intuitionalist approach and offers a globalization of local connectedness. He praises the local identity over the national and personal identities of both Europe and Latin America (Burity 2012: 82-83).

Subotic, on the other hand, from a purely realist perspective, in her analysis of the 'Europeanization of Serbia and Croatia' takes the national identity as the only identity and approaches the European Identity as another emerging national/ imperial identity (Subotic 20rI). While defining the identity from the minimal group paradigm of Tajfel's social identity theory, Ongur elaborates the European identity from the social psychology as counting each nation as a unit personality; hence, as with Subotic, the integrative analysis of European Identity again takes a classical realistic approach.

Gunther approached identity in Europe in the analysis of rapprochement between French and German identities as Françallemagne identity; he puts forward a mezzo identity which covers two national identities while not defining itself as a geographical one. On this amalgamation he refers to Ernest Renan's 
words on French unification where the same strategic path is used; forgetting the differences and painful memories of the past but blurring the differences between two nations, as occurred among Burgundian, Alan, Taifale and Visigoth identities (Gunther 2011: 48).

Guibernau, in her chronological analysis of the European integration process, takes identity from the functional perspective and acknowledges the national identity with respect to ethnic/local and continental identity. She concludes that the process of competing identities is rather incremental due to hardship in the invention of 'common causes and interests, symbols and rituals' (Guibernau 20II: 313). Dinç (20II) in his article approached the question of European Identity from a nomenclature perspective and referred the subject by comparing and contrasting national and religious identities while concentrating on the Europeanization process.

Srimayee Dam's (20II) analysis of national identity makes a distinction in identity construction between a civic/political and an ethnic/cultural one. For the civic/political one she refers to a mezzo-like national identity such as Gunter presents for the Franco-German case, but this resulted as a national identity, whereas the ethnic/cultural one refers to a rather ethnically and/or culturally homogenized national identity. While making this distinction, she refers to the former as part of Western and the latter as part of Eastern European culture (Dam 20II: 340).

On the other hand Kowalska, while she tries to define regional identity in all micro and mezzo senses, approaches the geographical constructors of identity using all national, religious and personal identities as a comparing and contrasting tool (2010: 165-167). But Kowalska is not the only one who stresses region as an identity constructor. Baba insists, statistically supporting her argument, on regional identity as Italians' personal identity constructor, by stating that regional or city identity is more salient in their definition of themselves than the national one (Baba 2010).

Lastly, Spohn, Fokas and Kurth stress religiosity identity as an identity constructor in Europe. Spohn's argument is that religious identity is treated from an ethnic perspective, theorizing it with multiple modernities, whereas Fokas builds up the same issue with a discursive analysis of the philosophic side of it. Although both researchers stress the secular character of European Identity, while the former mentions it politically, the latter emphasizes it as a principle. On the other hand Kurth elaborates a comparative perspective to religious identity in Europe within a historical perspective (Kurth 2007; Spohn 2009; Fokas 201I). 
From the analysis of recent literature, one can conclude that there are mainly four different types of identification; firstly, as the main identity of modern politics, the national identity would be counted as a unit identity; the second one would be listed as a micro level identity, which includes a sub-national level of regional identities and ethnic identities; the third one could be observed as macro-level identity as this is mainly the one that transcends national borders both philosophically and physically; and the last one would be called a nanolevel identity, since it can only be formulated from Marx's alienation concept, as a personal salient identity.

\section{Quantitative basis: variables, sample and tests}

In this analysis the WVS $5^{\text {th }}$ wave data for surveyed Council of Europe member states' respondents will be used in researching identity preferences in Europe. WWS is a survey output of an organized network of social scientists coordinated by a central body, the World Values Survey Association. The data cover a wide range of the world's population, with five waves of repeated survey (EVS and WVS, 2006). There are more than 800 variables, sprung from survey questions, that exist in this database, whereas unfortunately, due to different practices inside the international research consortium, not all variables are applicable to all countries and on all waves.

Even though the WVS data give a comparative insight into world population, because of this fact use of the database is confined to only some specific questions. For the purpose of our analysis six questions of the database will be used for salient identity preference of a respondent. Additionally, for the profiling of salient identities in Europe the two dimensions of Ronald Inglehart (1997: 67-107)-later with Welzel (Inglehart and Welzel 2005)- to measure the modernization and post-modernity level of a person will be used, as they are present in the WVS data. The variables that will be used are listed in Table I. Also, on the questionnaire, the questions that are coded with $G$ are asked in the Likert-Scale of four, the last question is asked in categorical (nominal) level form. The answer codes and labels are listed in Table 2.

Inglehart and Welzel's two-dimensional measure of social evolution, namely Traditional/Secular and Survival/Self-expression values, is extracted with factor analysis from the world values survey data. Inglehart, later with Welzel, modelled 
Table $\mathrm{I}$. List of variables that is used from WVS data.

\begin{tabular}{|l|l|}
\hline Variable & Label \\
\hline Go19 & I see myself as a world citizen \\
\hline Go20 & I see myself as member of my local community \\
\hline Go2I & I see myself as citizen of the [country] nation \\
\hline Go22C & I see myself as citizen of the [European Union] \\
\hline Go23 & I see myself as an autonomous individual \\
\hline Fo34 & $\begin{array}{l}\text { Independently of whether you go to church or not, would } \\
\text { you say you are... }\end{array}$ \\
\hline tradrat5 & TRADITIONAL/SECULAR RATIONAL VALUES \\
\hline survself & SURVIVAL/SELF-EXPRESSION VALUES \\
\hline
\end{tabular}

Table 2. List of variables response codes.

\begin{tabular}{|l|l|l|}
\hline Answer Code & Answer Labels \\
\hline & $\begin{array}{l}\text { For Go19, Go20, Go21, } \\
\text { Go22C, Go23 }\end{array}$ & For Fo34 \\
\hline I & Strongly agree & A religious person \\
\hline 2 & Agree & Not a religious person \\
\hline 3 & Disagree & A convinced atheist \\
\hline 4 & Strongly disagree & Other answer \\
\hline
\end{tabular}

a cultural change in a society using two basic parameters, the Traditional/Secular one represents the society's stand on pre-industrial to industrial transformation, while the Survival/Self-expression one represents the society's stand from industrial to post-industrial transformation.

Traditional/Rational (T/R) score: This factor score contains mainly the variables that are related to religion and authority among the values of the social group. If one needs a shortlist of names, the importance of family ties, obedience to authority (including the relative acceptance of military administration), and the acceptance of either challenge or compromise as a tool for avoiding a conflict might be counted as primary factors. Also the degree of nationalism and national pride is measured in this score. One can also state that this score measures how far the group is modernized. Mainly one can take the first score as

"the contrast between societies in which religion is very important and those in which it is not, but it also taps a rich variety of other concerns... Societies at the traditional pole emphasize religion, absolute standards, and 
traditional family values; favor large families; reject divorce; and take a prolife stance on abortion, euthanasia, and suicide" (Inglehart, 2000: 83).

Survival/Self Expression (S/S) score: This factor score contains mainly the society's transformation rate from a materialist to a post-materialist one. It also measures the importance of self-expression and the quality of life versus economic and physical security, etc. The second score is a characterization of

"tap[ping] an intergenerational shift from emphasis on economic and physical security toward increasing emphasis on self-expression, subjective well-being, and quality of life... [The second score is] linked with the emergence of growing emphasis on environmental protection, the women's movement, and rising demands for participation in decision making in economic and political life" (Inglehart 2000: 84).

When the European countries are extracted from WVS $5^{\text {th }}$ data, there are 20 countries that are found to have been surveyed (Table 3), but when counting the identity questions, we see that only 16 countries were surveyed for all six questions. Turkey is surveyed about all except EU membership. France, the Netherlands and the UK are only surveyed for religiosity. Since it is not the strong identification but the salience over other identities that is our concern in this analysis, those countries are excluded from the set.

Table 3. List of Countries in the WVS $5^{\text {th }}$ Data.

\begin{tabular}{|l|l|l|l|l|l|}
\hline I & Andorra & 8 & Norway & I5 & Ukraine \\
\hline 2 & Bulgaria & 9 & Poland & I6 & Serbia \\
\hline 3 & Cyprus & IO & Romania & I7 & Turkey \\
\hline 4 & Finland & II & Slovenia & I8 & France \\
\hline 5 & Germany & I2 & Spain & I9 & Netherlands \\
\hline 6 & Italy & I3 & Sweden & 20 & Great Britain \\
\hline 7 & Moldova & I4 & Switzerland & & \\
\hline
\end{tabular}

Also for the same reason, salience, only cases of respondents who strongly identify themselves with only one identity are included in the analysis; others -who strongly identify with more than one identity- are excluded. The result is listed in Table 4. This and further calculations are made through SPSS v.I9 programme outputs. 
률

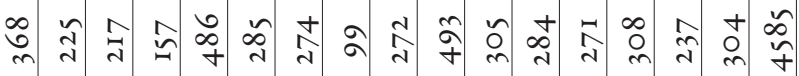

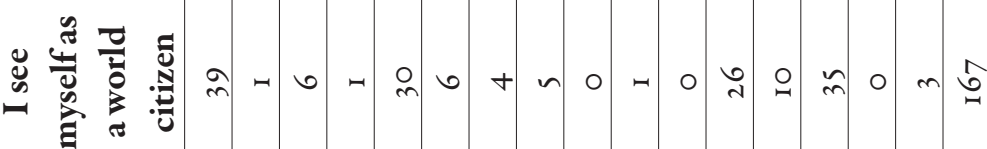

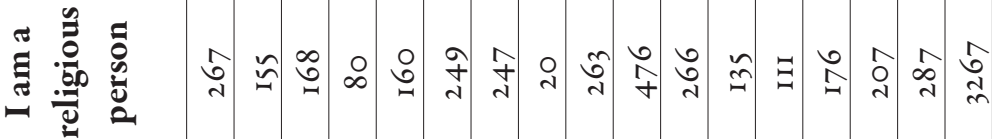

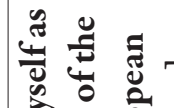

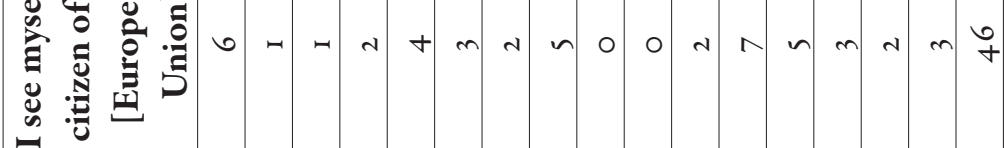
क वे

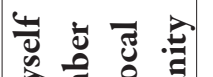

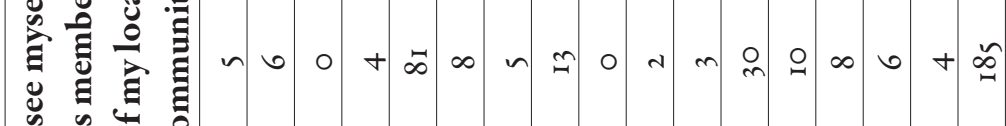

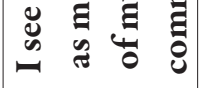

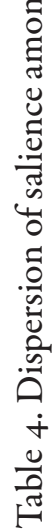

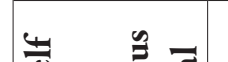$$
\text { (2) }
$$ 
It would be statistically wrong if one were to interpret Table 4 as the actual dispersion of identity saliences, since the excluded cases -of multi-affiliationsand their distribution for the comparative measurement of salient identity cannot be foreseen. However it would be in accord with general expectations to say that local identity salience is more present in Spain, Germany and Sweden as expected. Since our objective is not to tally, but to profile the types of salient identities, to use the elaborated data 'as is' will not be a scientific problem.

In order to profile the types of salient identities with respect to modernity and post-modernity preferences, the best method would be the use of Multivariate Analysis of Variance (MANOVA) since we take the categorical variables of identity salience as treatment (input) and the T/R and $S / S$ score as the response (outcome) scores.

"MANOVA uses the set of metric variables as dependent variables and the objective becomes finding groups of respondents that exhibit differences on the set of dependent variables. The groups of respondents are not specified; instead, the researcher uses one or more independent variables (non-metric variables) to form groups" (Hair 2010: 446-447).

In the case of MANOVA, there are three assumptions of the analysis to be checked (Hair 2010: 458-460):

- Independence; although it is a crucial assumption for the analysis, this assumption is assured by the WVS Association, in the details of sampling and interviewing methodology.

- Equality of variance-covariance matrices; the Box's M test indicates that there is no significant difference across the groups' covariance matrices. Table 5 gives the test results from the package programme.

- Normality; as the last precondition of the MANOVA analysis, the normality of dependent variables (T/R and $S / S$ ) should be tested. When the KolmogorovSmirnov test for normality is applied to the variables, unfortunately, the test result indicates that scores deviate significantly from the normal distribution. However, when the extreme values of the scores are analysed, it is observed that there are no outliers in the data, i.e. the scores are within the $[\bar{X} \pm 4 . s]$ margins. From this, one can conclude that the non-normality of the data is due to kurtosis or skewness. And "[w]ith moderate sample sizes, modest violations [of normality assumption] can be accommodated as long as the differences 
are due to skewness and not outliers" (Hair 2010: 460). Tables 6 and 7 are the results for the Kolmogorov-Smirnov test and the descriptive statistics of the $\mathrm{T} / \mathrm{R}$ and $\mathrm{S} / \mathrm{S}$ values.

Table 5 . Test result for equivalence of covariance matrices across groups.

\begin{tabular}{|l|c|c|}
\hline \multicolumn{3}{|l|}{ Test Results* } \\
\hline Box's M & & $\mathrm{I} 9.922$ \\
\hline F & Approx. & $\mathrm{I} .589$ \\
\hline & $\mathrm{dfI}$ & $\mathrm{I} 2$ \\
\hline & $\mathrm{df} 2$ & $\mathrm{I} 4060.589$ \\
\hline & sig. &, 087 \\
\hline
\end{tabular}

*Tests null hypothesis of equal population covariance matrices

Table 6. Results for Kolmogorov-Smirnov test for normality.

\begin{tabular}{|l|c|c|c|c|c|c|}
\hline \multirow{2}{*}{} & \multicolumn{3}{|c|}{ Kolmogorov-Smirnov* } & \multicolumn{3}{c|}{ Shapiro-Wilk } \\
\cline { 2 - 7 } & Statistic & df & Sig. & Statistic & df & Sig. \\
\hline $\begin{array}{l}\text { TRADITIONAL/ } \\
\text { SECULAR } \\
\text { RATIONAL } \\
\text { VALUES }\end{array}$ &, 088 & $442 \mathrm{I}$ &, 000 &, $94 \mathrm{I}$ & $442 \mathrm{I}$ &, 000 \\
\hline $\begin{array}{l}\text { SURVIVAL/ } \\
\text { SELF- } \\
\begin{array}{l}\text { EXPRESSION } \\
\text { VALUES }\end{array}\end{array}$ &, 053 & $442 \mathrm{I}$ &, 000 & 973 & $442 \mathrm{I}$ &, 000 \\
\hline
\end{tabular}

After ensuring the applicability of the MANOVA, it is time to apply the analysis. As is stated above, the aim of the analysis is to reveal the differences among groups, from the perspective of dependent variables. But as the number of groups increases, the explanatory power of the analysis decreases exponentially, since the number of categories in each variable (treatment) is multiplied for possible inputs, which for our case is $2^{6}=64$, and this brings more confusion to the analysis. Also since we are aiming at searching for salient identity, the multiple saliences are not an informative case for our purposes. Hence, instead of using six salience variables, it is more reasonable to use a single variable -salience- which has six categories as input. 
I84 MURAT SEVENCAN

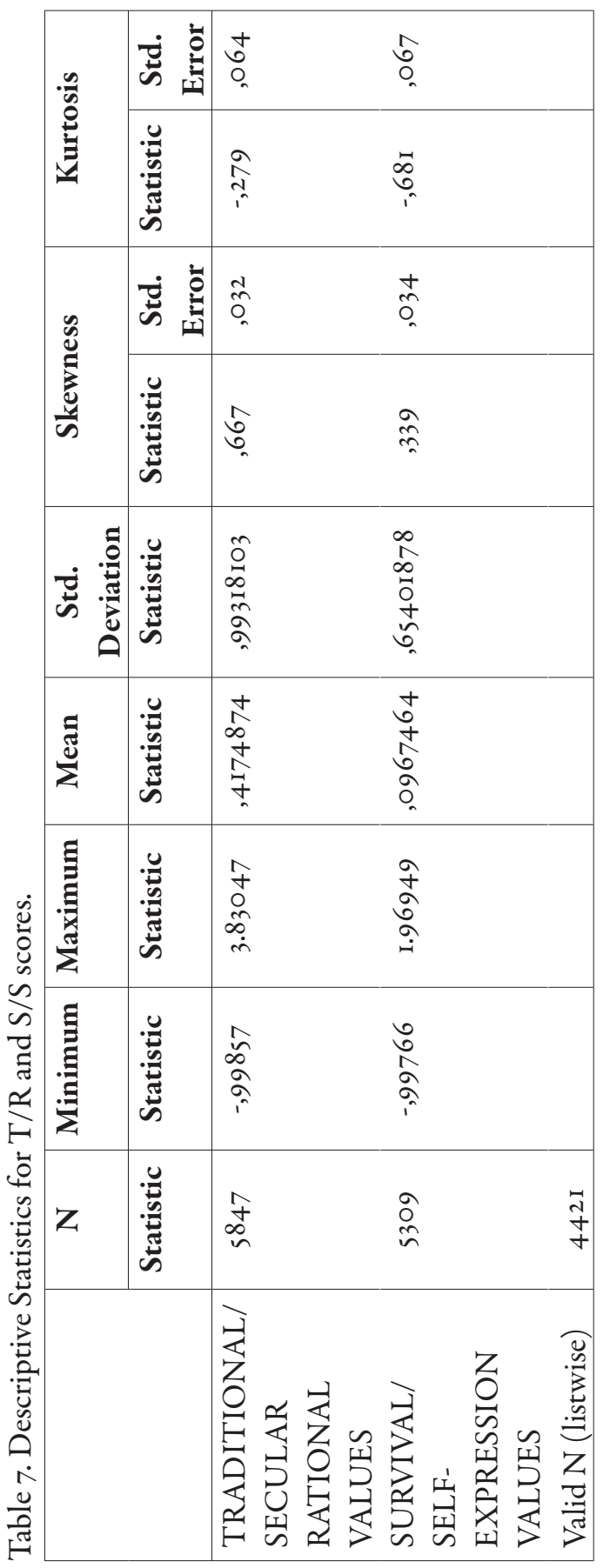


A MANOVA analysis that may be applied with salience as a marker, and with $\mathrm{T} / \mathrm{R}$ and $\mathrm{S} / \mathrm{S}$ as dependent variables shows:

$\mathrm{H}_{\circ}:\left(\mu^{T / R}, \mu^{S / S}\right)$ ordered pairs for all groups are equal, vs.

$\mathrm{H}_{\mathrm{r}}$ : For at least one group, $\left(\mu^{T / R}, \mu^{S / S}\right)$ pair is not equal to the other groups' pairs.

When the analysis was applied, the test results rejected the initial hypothesis with an asymptotic significance of 0 for all three of all four tests. Also the tests' power was 1,00 as well, as is shown in Table 8 .

Table 9 gives the mean $T / R$ and $S / S$ scores and their standard errors of each salient identity group; also Figure 2 shows the scores graphically by an ellipse with mean values pairs as the centre and standard errors as radii.

Since the test shows only that there is a grouping, but not the discriminating power of each category, we know for sure that at least one group mean pair is different from the other, but cannot be sure that each group differs significantly. A post hoc test needs to be done for further analysis. When Fisher's Least Significant Difference (LSD) test is applied to the dependent variables separately, there are some interesting results. Due to space economy, since SPSS result tables are too big, a summary table of significance values for LSD test is supplied as Table Io.' The upper-triangular matrix of the table gives the results for inter-classes $T / R$ comparison, whereas the lower-triangular gives them for $\mathrm{S} / \mathrm{S}$ comparison. Gray scores statistical failure for group distinction, the non-shaded ones indicates distinction.

\section{Statistical findings}

Although the MANOVA test results indicate that there are statistically significant differences among groups of salient identities, post hoc tests of the T/R and S/S point out that the deeper analysis does not permit us to conclude more:

Modernity: The first thing that strikes one about Table io is that the test results of $S / S$ scores - lower triangular matrix - show almost a total failure except between the religious and national identities. These results show that among the identity groups there is no preferential distinction, except the pair of national- 
I86 $\mid$ MURAT SEVENCAN

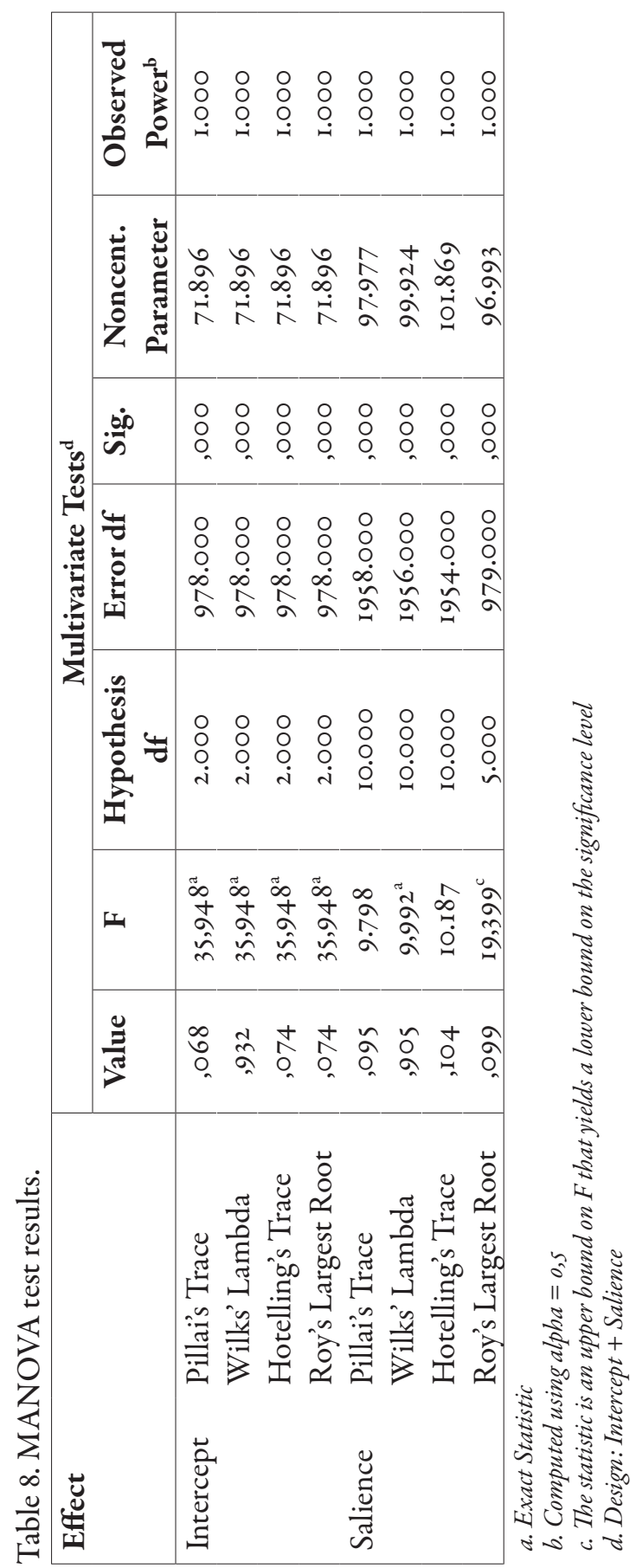


Table 9. Means of T/R and S/S scores for each salient identity.

\begin{tabular}{|c|c|c|c|}
\hline \multirow[t]{2}{*}{ Salient ID } & & \multicolumn{2}{|c|}{ REPORT } \\
\hline & & $\begin{array}{c}\text { TRADITIONAL/ } \\
\text { SECULAR } \\
\text { RATIONAL } \\
\text { VALUES }\end{array}$ & $\begin{array}{l}\text { SURVIVAL/ } \\
\text { SELF- } \\
\text { EXPRESSION } \\
\text { VALUES }\end{array}$ \\
\hline \multirow{2}{*}{$\begin{array}{l}\text { I see myself as } \\
\text { an autonomous } \\
\text { individual }\end{array}$} & Mean & 1.2901675 &,- 2339475 \\
\hline & $\begin{array}{l}\text { Std. Error } \\
\text { of Mean }\end{array}$ & ,I2968646 & ,I 4337045 \\
\hline \multirow{2}{*}{$\begin{array}{l}\text { I see myself as } \\
\text { member of my } \\
\text { local community }\end{array}$} & Mean & 8401597 &,- 2892314 \\
\hline & $\begin{array}{l}\text { Std. Error } \\
\text { of Mean }\end{array}$ & ,I 4434354 & ,I0743890 \\
\hline \multirow{2}{*}{$\begin{array}{l}\text { I see myself as citizen } \\
\text { of the [country] } \\
\text { nation }\end{array}$} & Mean & 8476374 &,- 3342017 \\
\hline & $\begin{array}{l}\text { Std. Error } \\
\text { of Mean }\end{array}$ & , 08939680 &, $066852 \mathrm{II}$ \\
\hline \multirow{2}{*}{$\begin{array}{l}\text { I see myself as citizen } \\
\text { of the [European } \\
\text { Union] }\end{array}$} & Mean & I.2802115 &,- 3168533 \\
\hline & $\begin{array}{l}\text { Std. Error } \\
\text { of Mean }\end{array}$ &, 25385730 & , 09287778 \\
\hline \multirow{2}{*}{$\begin{array}{l}\text { I am a religious } \\
\text { person }\end{array}$} & Mean &, 2741134 &,- 0369347 \\
\hline & $\begin{array}{l}\text { Std. Error } \\
\text { of Mean }\end{array}$ & ,02679161 & ,oI827918 \\
\hline \multirow{2}{*}{$\begin{array}{l}\text { I see myself as a } \\
\text { world citizen }\end{array}$} & Mean & $\mathrm{I} .2390412$ &,- 2996248 \\
\hline & $\begin{array}{l}\text { Std. Error } \\
\text { of Mean }\end{array}$ & ,I5630I3I & ,I2699168 \\
\hline \multirow[t]{2}{*}{ Total } & Mean &, 4220875 &,- 0629826 \\
\hline & $\begin{array}{l}\text { Std. Error } \\
\text { of Mean }\end{array}$ &, 02582167 &, 01733503 \\
\hline
\end{tabular}

religious identities, from the $S / S$ scores point of view. Since the $S / S$ score measures the person's desire to be free (for example at level of physical/national security), one can state that this is not the case when it concerns personal freedoms.

Religious exclusiveness: As can also obviously be seen from Figure 2, the post hoc test results for the $T / R$ scores indicate that there is a strong group difference ( 0,000 asymptotic significance) between religious identity and other identities. This deduction indicates that although there are religious, at least religion denomination-based, differences among societies, religious identity differs structurally from other identities. 


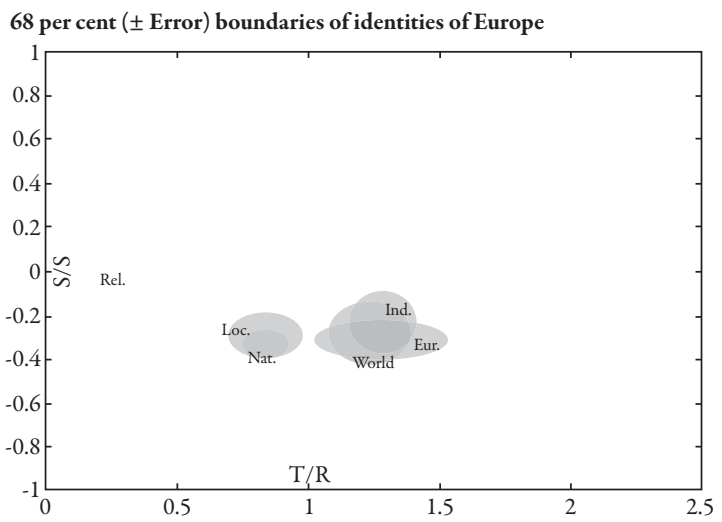

95 per cent $( \pm 2 \times$ Error) boundaries of identities of Europe

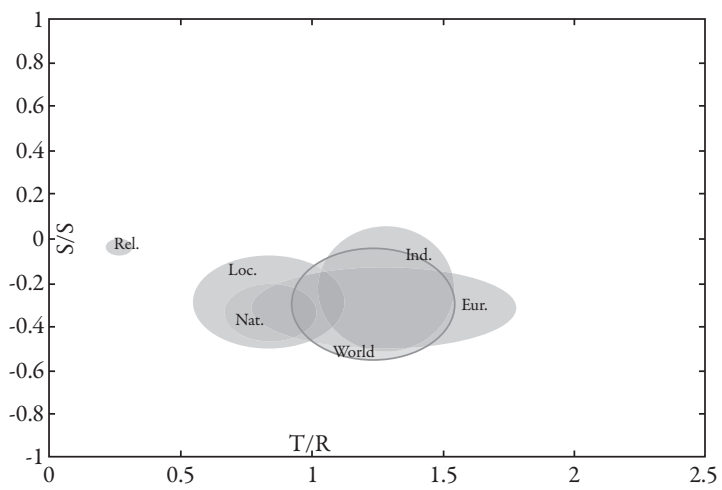

99.7 per cent ( $\pm 3 \times$ Error) boundaries for identities of Europe

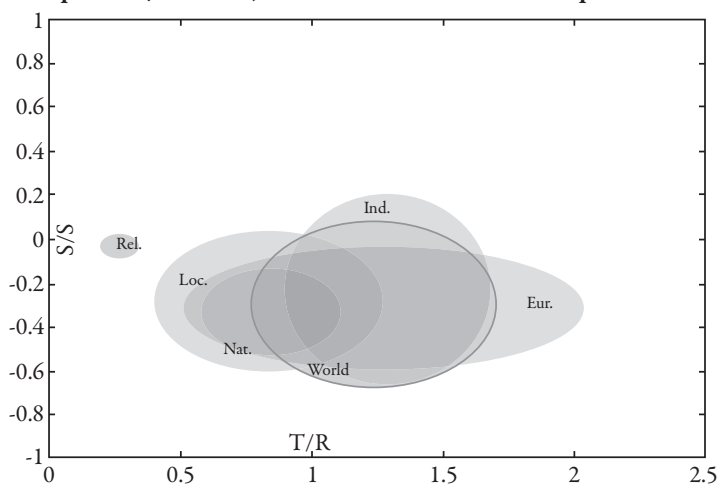

Figure 2 - Salient identity ellipses with centres of mean values and radii of standard errors of scores on coordinate plane 


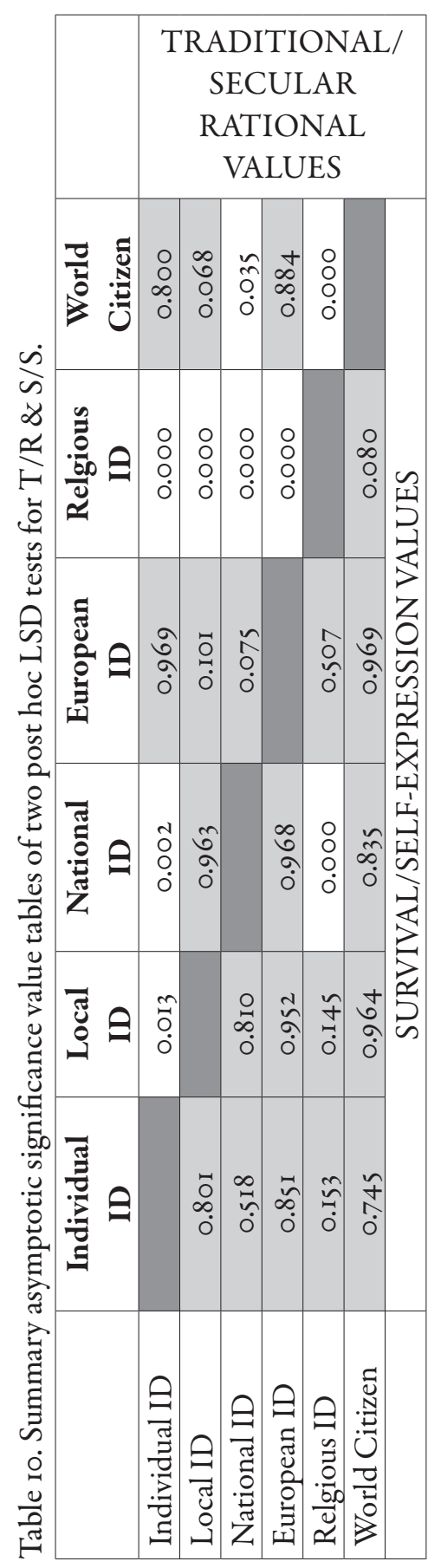


European Inclusiveness: The European identity's distinction test fails (at o,o5 significance level) all except for the religious and world identities. On T/R score it indicates that the boundaries of European identity are not strongly defined, and the group members that define themselves as European come from diverse levels of the traditional-rational scale. However, the identity's upper boundary is merely a stronger one. Statistical findings show a difference when it concerns transcending identities and this finding is not consequent with general finding on the Continent. One can be more sceptical indeed if the religious-European distinction is coming from the exclusiveness of the religious identity, which can not be stated.

One for all = all for one: Another interesting deduction from post hoc test results is that there is a strong statistical clue to the structural similarity between individual identity and world citizenship. This result would be counted as the clue that, although the ethical and emotional brandings of the identities are different, the practical results of them are observed to be the same. Since it is almost impossible to mobilize humanity, due to human nature, the actual practice of world citizenship is paradoxically nothing but individualism. Hence, the identity spectrum axis would seem to be a horse-shoe shaped one. (Figure 3).

Reassessment of unit identity: Last but not least, the failing asymptotic significance (for $\alpha=0,05$ ) of LSD test between national and local identities suggests that there is a strong structural correlation between the two identities, which suggests a stronger transitivity between them.

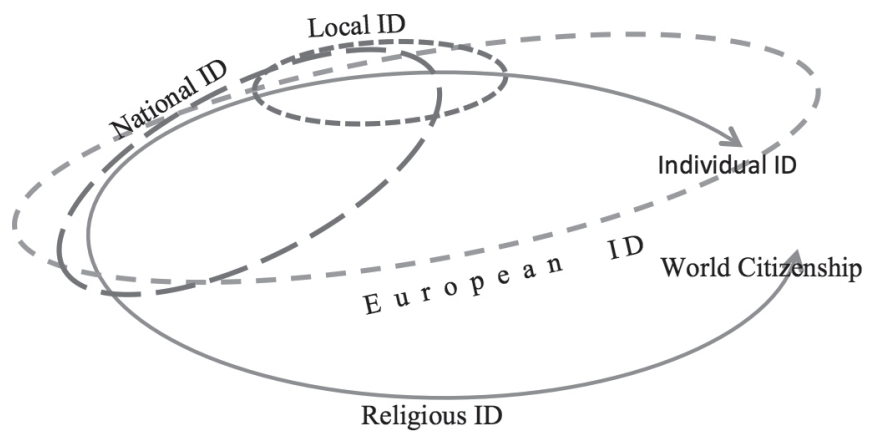

Figure 3 - Formation of identities in Europe 


\section{Conclusion}

The purpose of this study as stated at the beginning of this chapter was to answer two questions: 'What is challenging the salience of national identity?'; and 'Will it be evenly successful if one takes over its place by something else in the decisionmaking process of populi when it concerns the perception of international issues?' Although there is no certainty in social science, the deductions of a statistical survey can be used as an acceptable bearing for an answer.

As is stated in the statistical findings, although there are six categorizations of identities built from four levels of identification, socially there are three structures of life-views. The first and the most solid life-view is, with its definite boundaries, the modern-pious one. This life-view identifies itself with religious identity, which transcends geographical or political boundaries. While, one can sense a similarity between this and the old pre-modern super-identity of Christendom, one can believe that its ancestor is the Christendom understanding of life; it should be understood that this life-view is not the mere recurrence of the old one, but better accepts others in society. One can also say that this religious identity is a glocal one, and it formulates the identity categories in a post-secular philosophical sense. The higher mean S/S score agrees with this comment. Due to its discreteness from the other life views and its appreciation of the modern dichotomy of church and state, the mobilizing capacity and parameters of religious identity and national identity do not have collinearity. Hence, one can conclude that religious identity is not a challenge for national identity from a sovereignty perspective.

The second life-view can be called the modern-political life-view. This lifeview formulates the identity categories, in functional perspective, with respect to political perception. One can associate this structural life-view with both national and local identity. As has been mentioned, since national and local identities are fed from the same structural source, local identity is the nearest alternative to the national one. Therefore, as an answer to our first question, one can assert that the local identity is the more challenging one.

The last life-view is the hardest to put, since it concerns both nano and macro level identities, the individual and the world identity, within its boundaries. Although the meta-narratives of each identity in it differ, the stand due to the meta-narratives includes a socio-political self-choice of inclusion. Hence unlike the other types of identities that are externally defined, this structure of life-view is constructed from internal reasoning; thus it may be called a 
modern-intellectual life-view, and for positioning it with respect to the others they can be categorized as secular-glocal identities. Since the last life-view is not a political opinion but a rather philosophical stand, one can comment that the identities that are contained in this view do not constitute a challenge to national identity. Moreover, one can safely say that this secular-glocal identity also has a distance with the post-secular glocal one.

Although one may call the EU identity part of this last structural life-view, and in fact this is a reality from post-WW II on, because of its historical perspective this identity constitutes a hybrid one. Also since the official values that are constructed through reasoning 'do not constitute a proprium, (Habermas and Derrida 2003: 294) it has scattered support from two different structural life-views.

When we come to the attempt to answer the second question, one can comment that although the local identity cannot triumph over the national identity in the contemporary equilibrium, because of tidal waves of globalization and EU, the gluing factors of national unity 'melt in the air', and the national identity is forced towards its local partitions. Even if the contemporary responses to the forces of partitioning are moving in a more reactive and pro-nationalist direction, the need for coordination against ambitious economic and technological competition will eventually give way more to tame the national identity.

\section{Notes}

I For further discussion of sovereignty transfer see Sevencan M. (2008) Transformation of National Identities in EU and Turkish Identity. In: C. AC (ed) International conference on Social Sciences. Izmir: The Social Sciences Research Society, II9-133.

2 Actual SPSS test output can be accuired by contacting with the author via msevencan@ssu. edu.tr mailing address.

\section{References}

Anderson, B. (1991). Imagined communities: reflections on the origin and spread of nationalism. London; New York: Verso.

Baba, L. (2010). 'Italy vs. Europe: A Question of National Identity in a Global Era', Scientific Journal of Humanistic Studies 2: 53-62. 
Burity, J. A. (20I2). 'Civil Society and the Globalisation of Locality between Latin America and Europe: Integration as a Case of Agonistic Cosmopolitics,' Review of European Studies 4: $77-88$.

Dam, S. (2011).'Re-Interpreting the Civic-Ethnic Divide on the European Identity', Eurolimes: 329-342.

Dinç, C. (20II). 'Avrupa Kimliği: Çatışan Perspektifler, Güncel Değerlendirmeler ve Endişeler', (Turkish). European Identity: Conflicting Perspectives, Current Evaluations and Anxieties. (English) 5: 31-58.

Dyson, K. and K. Featherstone (1996). 'Italy and EMU as a 'Vincolo Esterno': Empowering the Technocrats, Transforming the State, South European Society and Politics r: 272-299.

EVS and WVS. (2006). European and World Values Surveys four-wave integrated data file. In: Group EVS and Association WVS (eds) v.20060423 ed.

Fokas, E. (20II). 'Islam In Europe: The Unexceptional Case,' Nordic Journal of Religion \& Society 24: I-17.

Guibernau, M. (2011). 'The birth of a united Europe: on why the EU has generated a 'nonemotional' identity', Nations \& Nationalism 17: 302-315.

Gunther, S. (2011). 'A New Identity for Old Europe: How and Why the French Imagined Françallemagne in Recent,' Years. French Politics, Culture \& Society 29: 46-67.

Habermas, J. and J. Derrida (2003). 'February 15, or What Binds Europeans Together: A Plea for a Common Foreign Policy, Beginning in the Core of Europe,' Constellations: An International Journal of Critical \& Democratic Theory 10: 291-297.

Hair, J. F. (2010). Multivariate data analysis, Upper Saddle River, NJ: Prentice Hall.

Hoffmeister, F. (2007). Constitutional Implications of EU Membership: a View From The Commission. Croatian Yearbook of European Law \& Policy 3: 59-97.

Inglehart, R. (1997). Modernization and postmodernization: cultural, economic, and political change in 43 societies, Princeton, N.J.: Princeton University Press.

Inglehart, R. (2000). 'Culture and Democracy', In: Huntington S.P. and L.E. Harrison (eds.). Culture matters: how values shape human progress. New York: Basic Books, xxxiv, $348 \mathrm{p}$.

Inglehart, R. and C. Welzel (2005). 'Exploring the Unknown: Predicting the Responses of Publics not yet Surveyed,' International Review of Sociology I5: 173-20I.

Kowalska, W.M. (2010). 'Between The Local, National And Global: The Problem Of "Regional Identities", Tarp Lokalumo, Nacionalumo Ir Globalumo: Regioniniu Tapatumu Problema. 3: 16I-169.

Kurth, J. (2007). 'Religion and National Identity in America and Europe', Society 44: I2O-I25.

Morozov, V. and B. Rumelili (2OI2). 'The external constitution of European identity: Russia and Turkey as Europe-makers,' Cooperation \& Conflict 47: 28-48. 
Rittberger, B. (2003). 'The Creation and Empowerment of the European Parliament*', JCMS: Journal of Common Market Studies 41: 203-225.

Sevencan, M. (2006). 'Bütünleşme Sürecinde AB ve Türk Kimliği Etkileşimi', Social Sciences Institute. Istanbul: Istanbul University, $32 \mathrm{I}$.

Sevencan, M. (2008). 'Transformation of National Identities in EU and Turkish Identity', in: C. AC (ed.). International conference on Social Sciences. Izmir: The Social Sciences Research Society, II9-I33.

Spohn, W. (2009). 'Europeanization, Religion and Collective Identities in an Enlarging Europe,' European Journal of Social Theory I2: 358-374.

Subotic, J. (201I). 'Europe is a State of Mind: Identity and Europeanization in the Balkans', International Studies Quarterly 55: 309-330.

Tamás, P. (200I). Public Perceptions of the Europeization and Sovereignty Debates in the Enlargement countries. 
CHAPTER IO

\title{
Democratic Theory and the Autonomy of Non-Christian Religious Courts in the UK
}

\author{
Ephraim Nimni
}

This chapter discusses the dilemmas of the relationship between religions of nonChristian minorities and the state in Western liberal democracies. It also explores the potential way out of these dilemmas offered by the limited autonomy granted in the UK to the Jewish orthodox Beth Din and, by implication, the autonomy of Islamic Shariah Courts, as sanctioned in the UK Parliament's (Divorce) Religious Marriages Bill 2002. It is argued here that this legislation has implications that go beyond the specific needs of the Orthodox Jewish community, to constitute an example of an embryonic democratic pluralism that leads to the creation of supplementary jurisdictions for non-Christian minority communities in the $\mathrm{UK}$, and the possible incorporation of both the Jewish Orthodox Beth Din and Islamic Shariah Courts into the English legal system.

\section{Introduction}

With the enactment of the Muslim Marriages Bill (South African Department of Justice and Constitutional Development: 2orr: Muslim Marriages Bill), South Africa has taken the lead in the question of the relationship between religions of non-Christian minorities and the state. For a discussion see Amien (2006). This chapter will discuss the dilemmas of the relationship between religions of nonChristian minorities and the state in Western liberal democracies.

Orthodox Jewish and Islamic courts have similar procedures on matters relating to religious marriages and, indeed, many other matters, including 
male ritual circumcision and the definition of pork as ritually unclean and forbidden for consumption. A marker of difference between these religions and Christianity is that worshiping images is forbidden in both religions. Kasher and Halal dietary laws have some similarities, the orthodox Jewish Kasher being the more strict. The ritual slaughter of animals permitted for human consumption is very similar in both religions. There are some differences in the consumption of alcohol, which is forbidden for Muslims and not for Jews, and in divorce procedures. There cannot be any doubt that Islam and Orthodox Judaism are the closest Abrahamic religions. It is an undisputed historical fact that both flourished in close contact, a fact that is unbearably obscured by the tragic and most unfortunate circumstances of the Israeli-Palestinian conflict. In light of this, any jurisprudential procedure or recognition of the autonomy of religious courts, however limited, of one of these two religions in Western liberal democracies, in which both are minorities, will necessarily have an impact on the other.

This chapter will also discuss the landmark contribution of Dr Rowan Williams, former Archbishop of Canterbury (Islam in English Law- civil and religious Marriages in England) to the creation of supplementary religious courts in the English Legal System, and thus allowing for the much better incorporation of religious Jews and Muslims into the British state.

\section{Secularism and secular democracies}

The concept of Democracy is inherently contested by different and often contradictory approaches and interpretations. These include the multiple, varied meanings that different people attach to the word democracy (O'Donnell 2007:6). There cannot be a single definition of democracy which satisfies all users and practitioners. It will be sufficient to recall that communist states define themselves as "People's Democracies" while western capitalist states usually adopt the name of "Liberal" or "Representative" democracies; the first is incompatible with the second. In distinction from the two above, religious democracy is a form of government where the principles of a particular religion inspire the laws and rules that govern the demos. Religious democracy is one of the many examples of how democracy coexists in different ethnic, cultural and religious contexts. Like their secular liberal counterparts, religious democracies can operate in accordance with accepted principles of popular representation, periodic elections, the accountability of office holders, and the rule of law. There 
is no reason to believe that a religious democracy that respects the egalitarian provisions of the democratic principles and rights of its minorities, either secular or religious, is less legitimate than a political system governed by secular liberal principles (Căbulea May 2009:169).

Unfortunately nowadays, the idea of religious democracies appears to clash with the early modern doctrine of an egalitarian "secular democracy", the alleged child of the universal values of the Philosophy of the Enlightenment. Following the 1789 Declaration of the Rights of Man and of the Citizen, which advocated government of the people by the people based on the rule of law originating on the values of universal secular reasoning, religion was eliminated from the public sphere (González, Lozano and Pérez 2009:254). This was advocated on two grounds. First, in order to avoid any form of coercion based on religious beliefs on the lives of citizens and, second and perhaps a more important normative justification, in the need to homogenize the population in the foundational need to elevate reason to a privileged position and simultaneously debase 'irrational' religious and other non-rationalist beliefs which were deemed incompatible with secular modern reasoning. From this it appears that Christianity was removed from a privileged position with the advent of a "superior" form of secular reasoning. Many believe it was superseded by the democratic nation-state, with its aspiration to build a distinct national identity. However, this may not be entirely the case. The nation of the state was in turn built upon a common history, language, tradition and culture, and many secularists believe that nationalism and the nation state came to displace religious belief as the foundation for integration into the national polity. However, this may not be quite so. The formal removal of Christianity by the French Revolutionaries, for example, did not preclude its persistent survival as an implicit foundation engrained in the secular dominant nation's tradition and culture. Since Europe has been Christian, even after the state had removed all or most Christian religious residues, it could well be that Christianity has endured by permeating the different European national cultures and traditions (Mancini 2010:499).

\section{Secularism and difference blind equality}

Difference-blind equality assumes that as long as no attention is paid to social difference, it will have no effect. In fact, as long as we pay no attention to difference, we will never overcome the inequalities that difference is used 
to sustain (Longo 200I:272). An ingredient of the idea of 'difference blind equality' that haunts contemporary liberal democracies could perhaps be found in the French Revolution's secularization of modern thinking. The values that informed the French Revolution were understood to be a form of superior secular rational thinking. This is, in a nutshell, a way of thinking that leads to the acceptance of the validity of propositions that are strongly supported by reasoned evidence and a rejection of propositions that are not (Kelly 2003:6I2). Religion is here disqualified on the grounds that it is a body of beliefs that cannot be explained by 'reasoned evidence'. Likewise, human nature is understood in universal terms, adhering to the belief that all humans are transcendentally equal. This epistemic assumption prevents the recognition of constitutive cultural or religious differences. This requires a more detailed philosophical exposition and has implications for an older vision of human rights, but these discussions cannot be entertained here. In a succinct manner we have here the genesis of what Taylor calls "difference blind" liberalism. These principles ignore their own temporality, in that they are themselves a reflection of particular cultures and perceive themselves as transcendental and neutral forms of reasoning (Taylor 1994:44). In addition, as Taylor equally reminds us, Liberalism is also a fighting creed (Taylor 1994:62). If this is the case, this particular kind of liberalism has no room for others in its proselytizing mission. This is, according to Taylor, "a particularism masquerading as universal” (Taylor 1994:43). Furthermore, this conveniently forgets that modern secular reasoning also has the propensity to be elevated to the category of dogma, and it is ardently sustained by actors who believe it is true (Gressgård 20I2:20). Here too, there is, regrettably, a propensity to confuse liberal democracy with a kind of militant secularism (Macklem 20I2:58I).

For centuries this type of liberalism was understood as a form of universal progressive thinking. As a result, a constitutional separation between religion and state has been implemented in many secular liberal democracies, confining religion to the private sphere with no role in the daily functioning of citizenship. As this separation is often enshrined in constitutions, secular republics find it difficult to recognize difference in the form of religious laws or jurisprudence. This egalitarian modus operandi, in which sameness and equality are often confused, results in a form of difference-blind liberalism, which provides each individual with a uniform set of rights and duties, regardless of culture, identity or beliefs (Laborde 2005:312). As will be shown in a moment, this modus operandi also affects some types of religious democracies, leading to the conclusion that it is not secularism per se that impedes the acceptance of minority religious jurisdictions, 
but a pervasive difference blind liberalism that has also tainted some religious democracies. These "difference blind" modalities of democratic government tend to alienate minorities, because decision making is done within the parameters of a dominant template, in disregard of the interests of an individual or minority group. They also weaken democratic theory because it misses the opportunity to see that some religious political movements and 'Political Islam' are sometimes programmes for religious democracy (Esposito \&Voll 2001:198-9).

\section{The separation of religion from the state}

In a stark rejection of the Peace of Augsburg's famous slogan cuius regio, eius religio (whose region, his religion) which demanded that the religion of the ruler coincide with the religion of the ruled (Conversi 2007:378), most liberal democrats believe that freedom of worship is secured for all religions by separating religion from the affairs of the state. This key normative assertion is not only held by liberals, but is also often held by religious writers, who argue that the separation of religion and the state contributes to enabling religion to be authentic and honest. The religious argument is that "Faith to be faith, prayer to be prayer, worship to be worship - all require a voluntary response, without the sanction of support of the state and without fear of coercion" (Wood 1991:229). In the United States, there is a deep-seated belief that religious freedom can exist only if there is a separation between church and state. For this reason, the constitutional first amendment prohibits civil courts from resolving religious disputes on the basis of religious doctrine and praxis (Scott 1996:1157).

In France, the concept of laïcité is inextricably linked with the Republican Ideal of liberté, égalité, fraternité, and it represents an important element of French Political identity. The term laïcité denotes the non-confessional character of the French state. In a very curious way, the principle of laïcité is the precise inverted mirror of cuius regio, eius religio. If the latter is the tyranny of one religion, the former is surely the tyranny of secularism. But this is of no importance to France, and was until recently of no importance to successive Kamalist regimes in Turkey. These principles were enshrined in the 1905 loi de Séparation des Eglises et de l'Etat and in the Fourth Republic's Constitution (Chadwick 1997:47). In the name of freedom of religion, and hiding behind the mantle of a difference-blind liberalism, the secular state relegates religion entirely to the private domain; in other words, firmly outside the jurisdiction of the state. In different shapes and 
forms, secular liberal democracies exercise a kind of 'benign neglect' of religious jurisprudence, by negating direct assistance to religious communities unless it is available to all, and even more so in the refusal to recognize the jurisdictional autonomy of religious courts in family law for example, which are central to defining religious membership (Oestreich 1999:I20-I).

\section{Coercion: religious or secular?}

The French and US models come from different normative directions. The United States gives primacy to religious liberty and the French republican model to equality of citizenship, which is understood to be secular. Yet, even if they come from opposing points of view, in their differing ways they converge in a common understanding of the need to separate religion from the state. While they differ in their approach to religion, these two models converge in what are normatively understood to be the liberal and republican conceptions of secularism (Modood 2009:72).

However, the relationship between freedom of religion and the separation of religion from the state is not as clear-cut as the high priests of secular modernity appear to indicate.

To be sure, liberals and democrats are on firm ground in critiquing the slogan cuius regio, eius religio, but remain somewhat inconsistent if they do not criticize laïcité with equal force. The full institutionalization of a particular religion in the organs of the state is coercive and oppressive to other religions and to secular citizens, and the exclusion of religion from the public domain is oppressive to religious citizens. Consider, for example, the case of Israel. The imposition of aspects of Jewish orthodox behaviour on the institutions of the state (Kasher rules, no public transport on the Sabbath, a regime of religious marriages only, etc) shows religious coercion in different areas of life. Among the many critics of the Israeli system is Haim H. Cohn, a distinguished judge of the Israeli Supreme Court, who called the religious coercion in Israel on matters of marriages and divorce a "Blot on Israel's Democracy” (cited by Karayanni 2012:325, see also Cohn 1998:110).

All secular liberal democracies include law-abiding religious citizens who conduct their private and public lives according to the canons of their respective religions. These religious citizens, as they experience a separation between religion and state in secular democracies, sometimes feel disadvantaged. In a paradoxical way, they find themselves in a similar situation to that of Israel's secular citizens, 
for they are disadvantaged by their religiosity in similar ways to those in which secular Israelis are disadvantaged by their secularity. A common example is marriage and divorce. Israel's secular citizens are disadvantaged because their state does not have recognized procedures for secular marriage and divorce. As will be explained in a moment, non-Christian religious citizens in secular liberal democracies are also disadvantaged in matters relating to marriage and divorce because the separation of religion and state impedes the recognition of religious rulings in such matters. Here, and in a perplexing and paradoxical way, it appears that the liberal democratic quest for a blind equality between citizens in secular procedures is the inverted mirror image of Israel's theocratic quest for the blind equality of its Jewish citizens in accordance with the cannons of the Jewish religion. The central problem lies in the liberal democratic assumption that liberal equality requires that all citizens be treated as homogenous and homologous individuals. The liberal principle of equal respect requires the secular state to treat citizens in a difference-blind fashion, devoid of any kind of religious connotation. The Israeli state treats its Jewish citizens, religious or secular, in accordance with the religious canon in a difference-blind fashion, not considering whether they are secular or religious. Charles Taylor goes as far as to argue that this liberalism that is blind to difference is in an insidious and subtle way homogenizing and discriminatory (1994:43). Whether religious or secular, difference-blind equality defaults in the dominant practice and excludes and alienates minorities. The three Abrahamic religions develop explanations of human rights that are generally grounded in religious texts, and, furthermore, they often appeal to historical praxis to establish their normative justifications (Afsaruddin 2008:57). For that reason, the exclusion of religious justifications of human rights undermines the acceptance of those rights by faith communities.

\section{The veil of ignorance}

As argued before, the neutrality of the state is more apparent than real. Its sovereign, the demos, is always concretely inserted in time and space in an insulated localized history, ethnos and religious tradition. But in spite of this, in the famous phrase coined by John Rawls (1999:108), a liberal state is required normatively to hold a "veil of ignorance rule" (a "veil rule"). This is a rule that suppresses the knowledge of decision makers of the religious adherence of its citizens in the name of neutrality and anonymity. The justification for this is 
that if rulers and ruled do not know the allegiance of the elected ruler, they will choose fairly because otherwise they might inadvertently choose someone who is detrimental to their interests (Moghaddam 2012:318). The individuals in Rawls' model are behind a veil of ignorance about their own culture or religion; the underlying assumption is that principles of justice developed here are for a homogeneous society. There is no recognition of the fact that humans differ in religion, speech, and culture, forming kin groups with distinctive characteristics that they cherish and want to preserve (Van Dyke 2004:727). Following this point, a Feminist critique of the "veil of ignorance" doctrine persuasively argues that this theory fails because on its choice of an abstraction of a "human being" in the exemplary image of a "normal" male member of the dominant group. This abstraction invokes the characteristics of a male and a member of the dominant majority. The consensus it creates is thus achieved by fiat (Matsuda: 1986:613-14). This criticism particularly applies to the discussion of the values of non-Christian minorities in secular democracies. The abstractions of the "veil of ignorance" subsume non-Christian communities into what they are not.

While the United States and France and most (but not all) Western democracies have unambiguous constitutional provisions that separate religion from state, the United Kingdom has no separation between Church and State. The state supports one particular religious faith, The Church of England, and The Head of State, the Queen, is the Supreme Governor of the Church of England. In the European Union, only the UK, Denmark and Greece are religious democracies, although of very different kinds. Religious democracies support a particular religion, and to some extent (it varies from case to case); religious values influence the political configuration of that state. There are some intermediate, ambiguous categories, for example, the Republic of Ireland's constitution declares that the state may not endorse any particular religion and guarantees freedom of religion, but the values of the Catholic Church influence important Irish laws (Cosgrove et alii 20II:I).

\section{Religious autonomy and transformative accommodation}

In part because of its multinational and religious pluralism, the UK does not hold a Rawlsian "veil of ignorance", and it is argued here that because of this, paradoxically, a section of its actually veiled citizens, orthodox Jewish and to some extent Islamic women, are granted a higher degree of autonomy and personal freedom than "veiled" liberal secularist democracies are able to afford. 
In contrast to a doctrinaire secularist understanding of the rule of law, which demands full compliance with the established secular legal procedure, or nonrecognition and alienation by the legal system, Ayelet Shachar (200I) advances a case in favour of "joint governance" and "transformative accommodation" of minority non-Christian religious communities. Unlike the sovereign state, transformative accommodation does not grant jurisdiction in "an all or nothing" fashion (Shachar 2001:126). Shachar advances instead the idea of a limited form of autonomy for religious courts, which provides a way for politically accommodating the claims of religious groups without endorsing any ruling or potential ruling that may contravene internationally accepted principles of human rights. Religious courts are understood as a public space offering a dialogical compromise of religious jurisprudence with the laws of the land and HR norms. The transformative character of the accommodation lies in the mutual adjustment between non-Christian minority religious courts and established principles of human rights. In this way, non- Christian minority religious courts realize that in order to remain relevant they must transform those practices that violate established norms of human rights. In other words, partnership and participation in the state system are possible only through mutual compromise between the state and the religious courts (Shachar 2001:125).

'Transformative accommodation' implies a willingness on all sides to contemplate internal change to accommodate subjects who are simultaneously members of both civic and religious communities (Jackson 2009:133).

Here the example is of Jewish Orthodox Religious courts, and the ongoing development of an Islamic Fiqh (Jurisprudence that deals with the observance of rituals, morals and social legislation in Islam), attuned to the needs of Islamic minority communities in Western societies (Fiqh al-Aqalliyyat, the fiqh, or jurisprudence, of Muslim minorities). The argument is based on the premise that all individuals utilizsing these jurisprudential services voluntarily agree to them and subject themselves to their jurisdiction without coercion. As there are differences between a Muslim majority and Muslim minority context, European Muslims are likely to develop different social and religious norms to regulate their lives. (Malik 2009:3) The "jurisprudence of Muslim minorities" (Fiqh al-Aqalliyat) attempts to present a strong Islamic foundation for a set of relationships of moral obligation and solidarity with non-Muslims (March 2009:34-35). This is a powerful integrative tool, one that fills an important gap in the consolidation of plural societies. Figh al-Aqalliyyat (the fiqh, or jurisprudence, 
of Muslim minorities) is a legal doctrine introduced by Shaykh Dr. Taha Jabir al-Alwani, and Shaykh Dr. Yusuf al-Qara-Dawi of Qatar. This fiqh maintains that Muslim minorities, especially those residing in the West, need a special type of Jurisprudence to take care of their religious needs, which differ from those of other faiths, and from those of Muslims residing in Islamic countries. It tries to resolve differences with the culture and values of the host societies from within the framework of Islamic jurisprudence. Its goal is to reinterpret some Islamic concepts, while at the same time not being a religious reform movement that breaches orthodoxy (Fishman 2006).

Veit Bader raises the question of the accommodation of non-Christian minorities in his model of associative democracy, which in many ways converges with the model of supplementary jurisdictions raised by Shachar The central idea of associative democracy is to encourage minority group representation that is compatible with the norms of democratic governance. Associative democracy, according to Bader, provides good institutional and policy opportunities to combine the protection of basic needs and rights of all and the protection of minimal liberal-democratic standards, as well as for accommodating divergent religious practices. Much like Shachar's model, it encourages minorities to reinterpret their best interests to facilitate their representation and accommodation (Bader 2007:177).

The non-availability of these courts of religious law, attuned to the needs of non-Christian minorities residing in liberal democratic societies, constitutes a harmful stumbling block in the process of integration of these religious minorities, by increasing their segregation and alienation.

\section{Rowan Williams' model of transformative accommodation}

Rowan Williams, the former Archbishop of Canterbury, relies on the conceptual argument of Shachar (a Feminist Jewish secular academic) in his plea for the incorporation of certain aspects of Shariah Law into English law. In an important homily he gave in 2008 , he was subjected to the abuse and scorn of the rather limited tabloid press that plagues the UK, which completely misunderstood his argument. Fortunately, his argument was later published in a scholarly journal (Williams 2008). In his thought-provoking article, Williams attempts to advance Shachar's overlapping jurisdictions to the arena of the recognition of religious law in a pluralist democratic state. 
Shachar's Multicultural Jurisdictions envisages 'joint governance' as a dialogical mode of politics whereby some authority in personal matters can be shared collectively by different non-Christian religious groups. She aims to transcend the dilemmas posed by secularism and the cruel binary understanding of secularist law encapsulated in the term "either-your-culture-or-your rights" (Shachar 2001:113). She offers instead a model of joint governance for institutional arrangements that seek simultaneously to prevent intra-group and extra-group cultural domination.

Rowan Williams argues that with the imposition of secularism, a failure of secular legal systems is to remove from consideration religious motivations and practices of groups in plural societies. He further argues that the defence of secular legal monopoly in terms of the universal doctrine of human right misunderstands the circumstances in which this doctrine emerged (Williams 2008:273).

In this he agrees that by ignoring minorities there is in Rawls' principle of the 'veil of ignorance' a biased abstraction harmful to the integration of minority communities. If the law of the land, Williams argues, fails to take religious motivation as a serious constituting element of the individuals concerned, then it fails to engage and integrate an important segment of society (Williams 2008:262), and creates not only a sense of alienation among the minority community, but also real issues of power and imposition. The impact of all this is crucially to undermine the overall cohesion of the body of citizens. Following Charles Taylor (2004), Williams argues that to be part as a meaningful participant, you need to be recognized as what you are. He then rhetorically asks whether a monopolistic approach to a legal system is a satisfactory basis for a modern pluralistic and democratic state. Might there be room, he asks, for 'overlapping jurisdictions', in which individuals can choose in certain limited areas whether to seek justice under one system or another? (Williams 2008:262).

Here the limited autonomy granted to the Orthodox Jewish courts becomes exemplary, and he invites the British state to act in accordance with this precedent, in relation to a religious community that exhibits many similarities with Orthodox Jews. To recognize Shariah, the former Archbishop argues, is to recognize a method of jurisprudence based on revealed texts, the interpretation of which varies with time, rather than to recognize a single system of jurisprudence (Williams 2008:264). He further argues that in the relations between Islam and English law, it is necessary to deconstruct crude binary oppositions and mythologies, and these refer the ignorance of the role and purpose of Shariah law or the domineering crude Manichean interpretation of the philosophy of the 
Enlightenment (Williams 2008:262). He proposes as a criterion for recognizing religious communities whether a communal jurisdiction interferes with liberties granted to the wider society (Williams 2008:273). Williams concludes by saying that to think intelligently about Islam and English law a fair amount of deconstruction of crude opposition and mythologies is necessary, whether about the nature of Shariah or the nature of the Philosophy of the Enlightenment (Williams 2008:274-5).

Following this logic, it is reasonable to conclude that the UK Parliament's legislation to create supplementary jurisdictions for non-Christian minorities is an important example of this.

The specific case discussed below is related to UK legislation that partially empowers religious tribunals of a non-Christian minority to pass specific rulings for their congregations. These rulings have in some limited form the status of the law of the land. It is argued here that the lack of the militant secularism and one-sided understanding of the Philosophy of the Enlightenment that characterizes republican models (France for example), which constitutionally inhibit the granting of any minimal autonomy to religious courts, facilitates the acceptance of this limited autonomy on matters of religious importance to minority communities. This kind of religious legal pluralism encourages the integration and loyalty of minority religious communities, as their members find in state mechanisms the recognition of their identity and way of life. In contrast, egalitarian secularist republics cannot employ such mechanisms and, contrary to their stated egalitarian aim, they increase the sense of alienation of religious minority communities.

\section{Divorce (Religious Marriages) Act 2002}

In order to understand the Divorce (Religious Marriages) Act 2002, it is necessary first to discuss the case of refusal of an orthodox Jewish divorce, the harm this creates for Jewish orthodox women refused divorce by recalcitrant husbands, and the remedial action taken in conjunction with the cannons of Jewish Halachaic law through the legislation enacted by the UK Parliament. This legislation was lobbied for by the Jewish community and enacted by Parliament in 2002. This legislation aims to resolve a human rights failure in Orthodox Jewish Law relating to discrimination against women in cases of religious divorce. What follows is a summary of the case and argument submitted to justify the passing of the Bill. 
But first it is important to understand that this Act has implications only for a small minority of Jews, those who adhere to orthodox Jewish practice and live their lives in strict adherence to the principles of the Halacha, the Talmudic literature that deals with the interpretation of the laws of the Hebrew Scriptures. This is the collective body of religious laws for Jews, including Biblical law, and Talmudic and Rabbinic law, as well as customs and traditions. Like Islam, Judaism draws no distinction in its laws between religious and ostensibly non-religious life; it does not distinguish clearly between religious and civil law. In the Islamic faith, there is a similar codification in the form of Shariah Law (the interpretation of the moral code and religious law of Islam). However, the majority of Jews do not adhere strictly to Halacha principles or they interpret them differently. Consequently, for this majority of Jews, the Act discussed below is irrelevant.

It has been also argued by Judge David Pearl that this Act deals exclusively with Orthodox Jewish Religious law. The object of the Act is to enable an English Court to order that a civil divorce be not finalized until both parties have taken such steps as are required to dissolve the marriage in accordance with Jewish Orthodox Law. However, there is a provision that this procedure can be extended to other religions. Judge Pearl argues that the position of Muslim women is different from that of orthodox Jewish women. A Muslim woman denied divorce from her husband can obtain a faskh from the Shariah council (Pearl: 2003:14). Indeed, upon application by a Muslim wife, a Shariah Court can grant a decree of divorce, in the form of a faskh, on any ground which it recognizes as valid, and this is indeed different from the Jewish Orthodox case. However, the important point of this Act and its relevance to the Islamic Community in the UK is that it establishes the precedent of the recognition of a religious tribunal (The Beth Din), and that this precedent can successfully be invoked for the recognition of an Islamic Religious Tribunal (Shariah court).

\section{The mechanism of a Jewish Orthodox divorce}

For a divorce to be effective in the Orthodox Jewish community (one that adheres literally to Halacha principles), a "get" must be obtained. A get is a consensual divorce in which mutual co-operation between the parties is required. The husband has to go before the Beth Din (Religious tribunal, akin to the Shariah Council in Islam) for a get and deliver it to his wife, and she is required to accept it. If he does not do so, the wife cannot remarry in Jewish law, although the 
husband may be able to do so (monogamy is not consensual in Judaism; some Jewish traditions accept polygamy on similar terms to those of Islam).

Sometimes a man will completely refuse to grant a divorce. This leaves his wife with no possibility of remarriage within Orthodox Judaism. Such a woman is called a mesorevet get (literally "refused a divorce"). A get refusal has very serious implications for a woman and it is tantamount to a serious violation of human rights. In Biblical times a woman who had sexual intercourse with a man other that her lawful husband or a man who could otherwise be her husband was deemed to be an adulteress (Noefet). The Biblical punishment for this was stoning to death at the place of public execution (Deut. xxii. 24). Fortunately The Talmudic Sages have softened this penalty, and contemporary Orthodox Judaism does not follow this procedure. Nevertheless, without a get, a woman who has a child by her subsequent partner is defined as a Noefet (adulteress under Jewish law), while the command in Deut. xxii 24 is not acted upon; her child becomes an illegitimate outcast (mamzer), which is a very serious stigma. $S /$ he is not permitted to become a member of the Jewish body politic (Deut. xxiii. 3 [A. V. 2]), and cannot intermarry with a Jew or Jewess (Jewish Encyclopaedia: Entry on Adultery); her child becomes an illegitimate outcast (mamzer), which is a stigma that carries on into future generations.

A woman who is trapped in a marriage that she seeks to end is called in Hebrew an "agunah" (a "chained" one), meaning one who is chained to a spouse against her will. If a wife refuses to accept her husband's get, he is known as an "agun". However, he does not suffer from the same disadvantages. A man who is refused a get by his wife has the option to seek an Hetermeahrabbanim (Hebrew: "permission by one hundred rabbis") This is a term in Jewish law which means that one hundred Rabbis agree with a Rabbinical court that a particular situation warrants an exemption to permit a man to remarry even though his wife refuses to accept a get. As a result, a husband can effectively hold his wife to ransom, and can demand money, property or other rights concerning custody or child maintenance in return for a get.

The Divorce (Religious Marriages) Act 2002 requires the dissolution of a religious marriage before a secular divorce is granted, empowering the Beth Din to grant this divorce, and in this way bringing equality to the situation, for the husband will not be able to remarry in a civil court if he does not grant his wife a get. The husband can also be coerced by the civil tribunal (using alimony, serious punitive costs, financial damages, etc) to grant the religious divorce, something that the Beth Din is unable to do because the Halacha requires that the husband 
concedes the Get of his own free will. (Divorce (Religious Marriages) Act 2002) The Act also empowers the Lord Chancellor to extend its provisions to other faiths, particularly in similar cases in the Islamic community. This implies the recognition not only of the Beth Din, but also of the Islamic Shariah Council, which ultimately rules on the dissolution of a religious marriage.

While this is an example of limited autonomy for religious communities, it is nevertheless important, for it deals with issues that are central to the lives of members of these communities. Furthermore, by this kind of recognition of the authority of their religious law, these communities can feel respected in their values and better integrated into the wider society.

Consider the opposing point of view, that of secular advice to a Jewish orthodox woman whose get has been refused. Simply go to a civil court and a judge will grant you the divorce you seek. Yes, sure, but, is it that simple? Is it not the case that such secular advice reveals a gigantic misrecognition, complete disregard and ignorance of the identity and lifestyle of this unfortunate woman? For in this case she will still be married in Jewish law, her orthodox father will throw ashes on his head, recite Kaddish, the Jewish prayer for the dead, tear his shirt, declare his daughter dead and sits Shiva, the Jewish period of mourning. No-one should be required to pay such a high price at the altar of monist and dogmatic Western secularism.

\section{Shariah and the transformation of Islamic Law in the West}

Other cases refer to the Islamic jurisprudential transformation of Shariah law through the adaptation of Western Islamic communities to their status as minorities, a central condition for acquiring a form of religious autonomy compatible with the values of human rights and the ethos of Western societies. This is another example of a dialogical mode of politics whereby autonomy can be shared among different religious groups.

The expansion of this idea will allow Shariah Councils to develop jurisprudential roles that will not clash with accepted values of human rights. The argument, however, goes further than the specific case of Islamic minorities in Western liberal democracies. Supporters of Fiqh al-Aqalliyyat argue that the developments being articulated in the Fiqh al Aqalliyyat are also relevant to the rights of non-Muslims in Islamic states. In understanding that in international law the right to preach Islam peacefully is safeguarded, the spread of norms of 
peaceful relations among states, religious freedom, the self-determination of peoples and the prohibition against aggressive war mean that the world has become the equivalent of one territorial jurisdiction, implying that law (at least public law) ought to be universal.

There is however controversy about these principles, not necessarily advocated by conservatives, but by others who see Islam as being sufficiently flexible to adapt to the circumstances of Western democracies without the need for a specific Fiqh (Parray 2012:88-106). In particular, Hellyer and Ramadan remain somewhat skeptical, for they prefer a vision that sees Muslims in Europe, rather than Muslims as a minority in Europe (Hellyer 2009:94-5, Ramadan 2004). Such a debate cannot be entered into here, for it is a discussion that ought to be pursued by the followers of the faith. However, this discussion shows a lively debate taking place between Islamic scholars as to what is the best method of accommodation of Islamic minorities in Western Liberal democracies. This debate replicates similar discussions in Orthodox Judaism and among other minorities in Europe, and it is a sure sign of the willingness to accommodate and peacefully coexist in the West. This willingness gives ample justification to Rowan Williams' request for supplementary jurisdictions for British Muslims, and to his project on integrating Shariah into English law, following the successful experience of the autonomy granted to the Jewish Beth Din. As argued earlier, any jurisprudential procedure or recognition of the autonomy of religious Jewish and Islamic courts in Western liberal democracies will integrate these religious minorities into the legal system; it will necessarily have an impact the other community, will undo alienation and exclusion and will encourage dialogue, compromise, peace and integration.

\section{References}

Amien, W. (2006). 'Overcoming the Conflict between the Right to Freedom of Religion and Women's Rights to Equality: A South African Case Study of Muslim Marriages,' Human Rights Quarterly, Vol. 28, 3, 729-754.

Afsaruddin, A. (2008). 'Making the Case for Religious Freedom within the Islamic Tradition,' The Review of Faith \& International Affairs, 6, (2), 57-60.

Căbulea M.S. (2009). 'Religious Democracy and the Liberal Principle of Legitimacy', Philosophy \& Public Affairs, 37, 2, 136-170.

Chadwick, K. (1997). 'Education in Secular France (re)defining Laïcité,' Modern \& Contemporary France, 5 (I), 47-59. 
Cohn, H.H. (1998). 'Religious Freedom and Religious Coercion in the State of Israel', in Kellermann, A.E., Siehr, K. and T. Einhorn (eds.). Israel Among the Nations: International and Comparative Law, MartinusNijhoff Publishers, 79-110.

Conversi, D. (2007). 'Homogenisation, Nationalism and War: Should we still Read Ernest Gellner?', Nations and Nationalism, 13 (3), 37 I-394.

Cosgrove, O., Cox, L., Kuhling, C. and P. Mulholland (2011). 'Introduction to Ireland New Religious Movements, Cambridge Scholars Publishing.

Divorce (Religious Marriages) Bill 2002 United Kingdom Parliament Publications, http:// www.publications.parliament.uk/pa/cm200102/cmhansrd/voorio23/debtext/IIO23-05. htm (Accessed r April 2013).

Esposito, J.L. and J.O. Voll (200I). Islam and Democracy. Oxford University Press, 232.

Fishman, S. (2006). 'Fiqh al-Aqalliyyat: A Legal Theory for Muslim Minorities', Research Monographs on the Muslim World, I, 2 October, Hudson Institute, Centre on Islam, Democracy, and the Future of the Muslim World.

González, E., Lozano, J. F. and P.J. Pérez (2009). 'Beyond the Conflict: Religion in the Public Sphere and Deliberative Democracy,' Res Publica, I5, 3, 25I-267.

Gressgård, R. (2012). Multicultural DialogueDilemmas, Paradoxes, Conflicts, Berghahn Books, Oxford.

Jewish Encyclopaedia, entry on Adultery, http://www.jewishencyclopedia.com/articles/865adultery Accessed 6 April 2013.

Jackson, B. (2009). 'Transformative Accommodation and Religious Law', Ecclesiastical Law Journal, II, 2, pp I3I-153.

Karayanni, M. M. (2012). 'Two Concepts of Group Rights for the Palestinian-Arab Minority under Israel's Constitutional Definition as a Jewish and Democratic State,' International Journal of Constitutional Law, Vol. Io, Issue 2 (March), pp. 304-339.

Kelly, T. (2003). 'Epistemic Rationality as Instrumental Rationality: A Critique,' Philosophy and Phenomenological Research, 66, 3, 612-640.

Laborde, C. (2005). 'Secular Philosophy and Muslim Headscarves in Schools,' The Journal of Political Philosophy, 13, 3, 305-329.

Longo, Patrizia (2001). Revisiting the Equality/Difference Debate: Redefining Citizenship for the New Millennium, Citizenship Studies, 5, 3, 269-284.

Macklem, P. (2012). 'Guarding the Perimeter: Militant Democracy and Religious Freedom in Europe,' Constellations, 19, 4, 575-590.

Modood, T. (2009). 'Moderate Secularism and Multiculturalism,' Politics, 29 (I): 71-76.

Malik, M. (2009). 'Muslim Legal norms and the Integration of European Muslims', Robert Schuman Centre for Advanced Studies, EUI Working Papers, RSCAS 29, European University Institute, Florence. 
Mancini, S. (2010). 'Supreme Court of the United Kingdom: To Be or Not To Be Jewish: The UK Supreme Court Answers the Question,' European Constitutional Law Review, 6, o3, 2010, pp 48I-502.

March, A. F. (2009). 'Sources of Moral Obligation to non-Muslims in the Jurisprudence of Muslim Minorities,' Islamic Law and Society, I6, 34-94.

Matsuda, M. J. (1986). 'Liberal Jurisprudence and Abstracted Visions of Human Nature: A Feminist Critique of Rawls' Theory of Justice', New Mexico Law Review, 16, 613-630.

Moghaddam, F. M. (2012). 'The Omnicultural Imperative', Culture \& Psychology, 18, 304-330. O’Donnell, G. (2007). 'The Perpetual Crises of Democracy, Journal of Democracy, I8.I, 5-II.

Oestreich, J. E. (1999). 'Liberal Theory and Minority Group Rights', Human Rights Quarterly, 2I, (I), I08-132.

Parray, T. A. (2012). 'The Legal Methodology of Fiqh al-Aqalliyyat and its Critics: An Analytical Study,' Journal of Muslim Minority Affairs, 32, 1, 2, 88-106.

Pearl, D. (2003). 'Dispute Settlement Amongst the Muslim Community in the UK,' Recht van de Islam 20, pp. 5-16.

Ramadan, T. (2004). Western Muslims and the future of Islam, Oxford University Press, Oxford.

Rawls, J. (1999). A Theory of Justice, Oxford University Press, Oxford.

Scott, P. A. (1995-6). 'New York Divorce Law and the Religion Clauses: An Unconstitutional Exorcism of the Jewish Get Laws', Seton Hall Constitutional Law Journal, (6), III7-I190.

Shachar, A. (2001). Multicultural Jurisdictions: Cultural Differences and Women's Rights, Cambridge University Press, Cambridge.

South Africa, Republic 2oII, Department of Justice and Constitutional Development, “Muslim Marriages Bill”, http://www.justice.gov.za/legislation/bills/2010_muslimmarriages-bill.pdf Accesed I April 2013.

Taylor, C. (1994). 'The Politics of Recognition', in Gutmann, A. (ed.). Multiculturalism: Examining the Politics of Recognition, Princeton University Press, pp. 25-74.

Van Dyke, V. (2004). 'Human Rights and the Rights of Groups', American Journal of Political Science, I8, 4, 725-74I.

Wood, J. E. JR (1991). 'Religion and Religious Liberty', (Editorial) Journal of Church \& State, $33,225-30$. 


\title{
CHAPTER I I \\ Islamophobia and the Crises of Europe's Multiculturalism
}

\author{
Chris Allen
}

The manifesto of Anders Behring Breivik made clear who he saw as the 'enemies' of contemporary Europe: Islam and multiculturalism. Such views are not the preserve of Breivik and the far-right however; similar views are routinely expressed across Europe's political landscape. Whilst Germany's Angela Merkel, Britain's David Cameron and France's Nicolas Sarkozy explicitly declared that multiculturalism was dead, less explicit was the suggestion that Islam and Muslims were to blame. As Parekh puts it, the crisis of European multiculturalism depends upon answering the 'Muslim Question'. This chapter explores some of these key issues in the British context before widening its focus to include Denmark, the Netherlands and Sweden. In conclusion, contemporary discourses about the crises of multiculturalism are evaluated as regards their potential to feed into and reinforce Islamophobic discourses in both the social and political spaces of Europe.

\section{Islamophobia and the crises of Europe's multiculturalism}

As much as his actions were chilling, some of the points made by Anders Behring Breivik in his manifesto entitled, 2083: A European Declaration of Independence were undoubtedly timely and interesting enough to engage a whole range of different audiences across Europe. Published shortly before he launched a bomb attack on government buildings in Oslo followed soon after by a mass shooting 
at a youth camp on the island of Utøya, Breivik used the manifesto to set out his rationale for taking the lives of the 77 people many of whom were teenagers. Rooted in the ideologies of the far-right and neo-Nazism, Breivik's remit was wide: endorsing extreme forms of Zionism, white nationalism and right-wing populism whilst simultaneously promoting Islamophobia, cultural conservatism and anti-feminism along the way. Underpinning all of this however were the issues that Breivik identified as the enemies of modern Europe. For him, Islam, 'cultural Marxism' and multiculturalism were the enemies; the enemies that would eventually combine to establish 'Eurabia'. Only the violent and wholesale annihilation of multiculturalism would - in Breivik's mind at least - preserve Christian Europe.

It is not only Breivik and those on the extreme fringes of Europe's political landscape that have identified multiculturalism as being wholly problematic. Across the mainstream too, multiculturalism has come under attack in recent years. Germany's Angela Merkel began the attacks in October 2010 explaining how in her country, "the approach [to build] a multicultural [society] and to live side-by-side and to enjoy each other... has failed, utterly failed". Britain's David Cameron joined the attack a few months later in February 20II:

\begin{abstract}
"Under the doctrine of state multiculturalism, we have encouraged different cultures to live separate lives, apart from each other and apart from the mainstream. We've failed to provide a vision of society to which they feel they want to belong. We've even tolerated these segregated communities behaving in ways that run completely counter to our values...Frankly, we need a lot less of the passive tolerance of recent years and much more active, muscular liberalism"
\end{abstract}

In the same week, France's Nicolas Sarkozy continued, "We have been too concerned about the identity of the person who was arriving and not enough about the identity of the country that was receiving him...multiculturalism has been a failure". For those in the political elites of Europe it would seem clear: despite the fact that multiculturalism is a physical and demographic reality across vast swathes of twenty first century Europe, it is now a problem, a challenge and more potently, a threat. If Breivik is to be believed, this threat is to the very existence of Europe as we currently know it. But to what extent is this true? Given the factual reality of multicultural societies across the breadth of today's Europe multiple peoples of different ethnicities, cultures, religions, languages and so on 
living alongside each other - this chapter considers Europe's multiculturalism, what might lie at the heart of the current 'problem' and more importantly, why this is important when considering the future of Europe.

\section{Considering multiculturalism}

Despite its widespread usage and adoption, 'multiculturalism' remains a relatively recent phenomenon in political and social theory. Standard works are little more than thirty years old (e.g. Kymlicka 1989; Young 1990). Following the demographic changes that have occurred in the past half century in much of Western Europe as a result of mass migration and other forms of immigration, 'multiculturalism' is very much a fact of society in many states given the levels of diversity and group difference that currently exists. Despite this, it is worth noting that some European states might not necessarily or self-consciously declare themselves to be. As Kelly puts it, all modern Western European states face the 'problems' of multiculturalism even if they are far from endorsing multiculturalism as a policy agenda or political ideology (Kelly 2002). Most significant is the fact that large minority communities live in relative socioeconomic deprivation and struggle culturally, politically and religiously against discrimination and in the need to be recognised. Kelly describes this as being consequential of the "circumstances of multiculturalism" of which two exist (Kelly 2002:3). The first of Kelly's circumstances is 'factual multiculturalism' where more than one culture exists within the public realm and is seen to be largely uncontroversial. Whilst true, there remains a dominant culture that the majority would identify with that has the potential to fetish, essentialise or reduce minority cultures in a variety of different ways. The second circumstance is 'prescribed multiculturalism', a socio-political theory and model which seeks to apply egalitarian or libertarian principles of justice and rights as a means of trying to redress the 'problems': the consequences of group difference and conflict for example, discrimination and racism. It is this latter understanding of multiculturalism - as a prescriptive socio-political theory and model - with which this chapter is primarily concerned with.

Europe did not 'invent' the notion of multiculturalism. Drawing upon debates and political developments that were taking place in places such as Canada and the United States in the 1970s and 1980s (Kymlicka 1989; Young 1990; Taylor 1994), a handful of Western European states began to follow suit. In countries 
such as the United Kingdom (UK), the Netherlands and Sweden - states that self-consciously adopted what might best be termed prescriptive multicultural socio-political models albeit with some differences - concretised 'solutions' to the 'problems' were sought to guarantee equal rights and recognition for different ethnically, culturally and religiously identified communities. Extending debates around liberal democracy, for some such as Parekh, much more was needed: multicultural states needed to support minority communities to uphold their linguistic, cultural and religious needs and to outlaw the discrimination and disadvantage they experienced because of this (Parekh 2000). However, this form of multiculturalism was not without criticism. Some advocated that the promotion of individual rights rather than those of groups or communities as in the prescriptive multicultural model would be more beneficial (Joppke 1999; Barry 2002). For them because the emphasis is on groups and communities and the identities associated with them, multiculturalism gave greater credence to particularistic identities thereby not only focusing on cultural and religious difference but so too encouraging it (Scuzzarello 2010). As some argued, this approach legitimised the desire for self-separation within some communities. Advocates of multiculturalism will often forcefully counter this by stressing the benefits of recognising a plurality of identities, deeming it to be an overriding strength (Parekh 2000; Modood et al. 2006).

In the UK, Netherlands, Sweden and elsewhere in Europe, it has been this type of prescriptive socio-political model of multiculturalism that has been established. In the Netherlands, this emerged out of the Minderhedennota, a policy that was ratified by Parliament in 1983 on the basis that Dutch society had become multiethnic and so both majority and minority communities should live together in harmony and mutual respect. The goals of this were: emancipation; equality; and equal opportunity (Carle 2005). In Sweden, the principles of jamlikhet (equality), valfrihet (freedom of choice) and samverkan (partnership) were the key foundations upon which it built its immigrant policy, a policy that sought to distance and indeed reject the 'guest worker' strategy preferred in other Western European states especially Germany (Alund and Schierup: 1991). In the UK things were slightly different with notions of multiculturalism emerging out of ideas and debates that followed the publication of the Swann report in the 1980 os. It is this report that in the British context is seen to mark the formal beginning of a state endorsed multicultural model that required free choice for individuals, active support for the essential elements of the cultures and lifestyles of minority groups, and the acceptance of a framework of shared values 
through which the interests of the greater good would be upheld (Bhattacharya 1998).

Whilst far from being European in its conception, the values underpinning multiculturalism undoubtedly resonated with those already present in various European liberal states and so it is unsurprising that multiculturalism was embraced across Western Europe in particular. Where individual states did adopt and individualise multiculturalism, the result was a range of different concrete social and public policies being implemented which sought to guarantee a variety of different rights and privileges for minority communities. In essence, each adopted an individualised version of 'prescribed multiculturalism'. Whilst different in policy and implementation, and indeed in the histories and heritages that shaped the respective journey towards multiculturalism - for instance some countries were former colonial powers, others were not - similarities were shown to exist. These tended to include a general policy of 'non-intervention', where different communities - shaped and determined by ethnic, national, religious, cultural or other identifiers - are seen to deserve respect as do their differences. As Kymlicka put it, these different models based upon "liberal view[s] required freedom within the minority group and equality between the minority and majority group" (Kymlicka 1995:117). However, Kymlicka was also quick to warn of the potential consequences of this type of approach: "In cases where the national minority is illiberal, this means that the majority will be unable to prevent the violation of individual rights within the minority community. Liberals in the majority group will have to learn to live with this" (Kymlicka 1995:168). To explore this in more detail and to try and better understand the crises of multiculturalism in today's Europe, a case study on the crisis of multiculturalism in the UK is followed by a consideration of the same issues elsewhere in Europe.

\section{The crisis of multiculturalism in the UK}

In trying to understand the 'crisis' of multiculturalism in contemporary Britain, it is necessary to consider the debates that took place in both the public and political spaces following the London terror attacks in July 2005 (' $7 / 7$ '). The central tenet of the British 'crisis' focused on how $7 / 7$ had not only catalysed but so too brought about the 'death of multiculturalism'. As Modood noted, in the 12 weeks following the terrorist atrocities a significant number of different commentators used the events as a springboard from which to espouse their 
arguments against multiculturalism (Modood 2005). Included amongst these were Gilles Kepel suggesting the bombers had smashed multiculturalism 'to smithereens' and Trevor Phillips - chair of the then national race equality watchdog, the Commission for Racial Equality - who questioned whether, in the context of an 'anything goes' multiculturalism, Britain had focused too much on the 'multi' and not enough on the 'common'. Numerous other politicians, commentators and institutional voices entered the debate and suggested similar. But as Parekh noted, underpinning the attacks on multiculturalism - whether implied or simply assumed - were closely veiled attacks on Muslims and Islam. For him, the 'crisis of multiculturalism' debates that followed $7 / 7$ were little more than a polite code for addressing what many saw was the 'problem' posed by Muslims and Islam in Britain (Parekh 2000). More recently and more widely, Breivik also made this connection albeit far more explicitly.

In the British setting, much of the debate around the crisis of multiculturalism became synonymous with softer manifestations of Islamophobia, where discourses disproportionately focused on the perceived threat Muslims and Islam were seen to be posing to 'our' culture, 'our' values, 'our' institutions, and 'our' way of life (Allen 2005). Whether overt or covert, Muslims and Islam had become inculpably blamed for the ills of contemporary British society. Interestingly, from across the political spectrum, extremely similar arguments and justifications against Muslims and Islam emerged. Voices from across the political spectrum were beginning to perceive Muslims and Islam as making politically exceptional, culturally unreasonable and theologically alien demands on the state (Modood 2006). Following a series of highly publicised terror raids and an additional number of failed or thwarted terror attacks, debates about the role and responsibilities of Muslims and Islam intensified. Consequently, this questioning has continued and has sought to ask whether Muslims can be - or indeed ever will be - an integrated part of a modern, egalitarian, society. Maybe the question that some had wanted to ask was whether Muslims can - or indeed ever will be - an integrated of a multicultural society?

Against this backdrop, two loosely defined and politically categorised antiMuslim, anti-Islam ideologies begun to emerge. The first was more explicit, overt and formally structured from what might be termed the 'far-right milieu'. In Britain, this has comprised organisations that traditionally sat on the extreme, nationalist end of the political spectrum. Seen for example in the British National Party ('BNP'), its campaigns called for 'Islam out of Britain' and the need for a 'referendum' on the future of Islam in Britain. Making unprecedented 
electoral gains at local, London and European levels in the aftermath of $7 / 7$, the BNP was extremely successful in finding political resonance with a significant part of the population. Despite unprecedented success at the local and European levels, it failed to translate this success into national electoral gains and in the past few years has begun to fracture under the weight of responsibility and relative political respectability. Even more recently however, there are signs that the BNP is once more strengthening. Also within the 'far-right milieu' is the English Defence League ('EDL'). Established around four years ago, it grew rapidly and at its zenith had the capability to mobilise up to 3,000 supporters to march through towns and cities in protest of the 'Islamification of Britain'. It is this group that Breivik is alleged to have been in dialogue with in relation to his views about Muslims, Islam and the 'Islamisation' of Europe. For the EDL, Islam and Muslim difference - 'their' innate difference from 'us' - is where the problem lies. As with the BNP, the EDL too has begun to fracture into, at times, more violent and more extreme splinter groups each of whom have a clear anti-Muslim, anti-Islam ideology at its core.

The second emergent ideology is far more implicit, and lacks the more formal structures and organisations of the far-right milieu. Linked by ideologically informed discourses and rhetoric, this might be termed 'secular liberalist'. Possibly reflecting Kymlicka's dilemma facing liberals, of 'learning to live with' what they perceive to be illiberalism, the ideological messages and meanings of the secular liberalists are typically hidden behind or embedded within debates and arguments associated with other issues. Voices from within the secular liberalist have tended to associate the 'crises' of multiculturalism with other social and political issues, including those relating to immigration, integration, community cohesion and the erosion of liberal values especially freedom of speech and equality. Voices that one might be understood as operating within this category include the columnist Polly Toynbee and her suggestion that she was an 'Islamophobe' and proud (Allen 2010), the editor of left leaning magazine David Goodhart and the inference of Muslims with 'stranger citizens' (Allen 2007), and those such as the former Home Secretary Jack Straw and his suggestion that the niqab - face veil - was a blanket barrier to integration (Allen 2010). Because the arguments and ideas put forward are typically far more implied, secular liberalist questions about Muslims and Islam are far more likely to go unnoticed or unrecognised in comparison to its far-right opposite (Allen 2007). More so, secular liberalist notions of the 'problems' of Muslims and Islam tend to be rooted in the values that sit at the heart of the modern liberal state and so tend to acquire a much 
wider public and political support, including from those operating within the mainstream of the political state. Across Europe, other discourses which emerge from the secular liberalist perspective include those relating to the perceived notion of 'Eurabia' or the 'Islamisation' of Europe, both of which have a direct resonance with similar ideas emerging from the far-right.

\section{Beyond Britain}

These processes are far from limited to the British setting. In both the Netherlands and Sweden for instance, there are many similarities. At the political level in the Netherlands, Lijst Pim Fortuyn (LPF) made significant political inroads. Pim Fortuyn, its assassinated leader, campaigned by calling Islam 'a backward culture' and stating that he would close Dutch borders to Muslim immigrants if it were legal. Fortuyn also spoke about the 'Islamisation of Europe'. Interestingly though, Fortuyn would not have placed himself within the 'far-right milieu'. Instead Fortuyn described himself as a 'socialist' and so might more appropriately sit within the secular liberalist ideologies. More typical of this ideological standpoint would be Somali-born Ayaan Hirsi Ali. A feminist who scripted the controversial film 'Submission' by Theo Van Gogh - who was himself murdered in protest of his film - Hirsi Ali has argued that Islam is incompatible with democracy and Western culture. More recently, politician Geert Wilders - who courted controversy with his controversial film, 'Fitna' - recently saw his Partij voor de Vrijheid (PVV) emerge as the third largest political party in the Dutch parliamentary elections in 2010, support that some have argued was on the back of his stance against Muslims and Islam.

In Sweden, and as with the PVV in the Netherlands, the Sverigedemokraterna (SD) achieved unprecedented success in 2010 national elections in ways where the more traditional lines between the political right and left were blurred. Being the first time the SD or any political organisation from the right had attracted enough votes to cross the necessary threshold to gain parliamentary representation, the success of the SD is entirely new in the Swedish context. Campaigning that Sweden's multiculturalism and multicultural policies had failed, the SD asserted that Sweden's approach to immigration and integration had threatened national identity and had destroyed social cohesion. Its identification of the 'problem' underlying the crisis of multiculturalism was clear: a banned advertisement for the SD showed a race between women in burqas with an elderly indigenous 
Swedish woman for state benefits. As elsewhere, debates have also emerged from the centre and left of the public and political spaces following a series of death threats - and subsequent arrests - made to Lars Vilks, a Swedish artist who produced a series of drawings of the Prophet Muhammad as a dog. Following the angry response from Muslims both in Sweden and elsewhere in the world, much was made of the need to stand up for freedom of expression not least because it is enshrined in the Swedish constitution.

In other European countries too, similar has occurred. For instance in Denmark, a country placed under the international spotlight following the publication of cartoons of the Prophet Muhammad in January 2006, the Prime Minister has in the past publicly criticised Muslims for unnecessarily taking up to 'four' prayer breaks at work each day whilst the Dansk Folkeparti (Danish People's Party) has been reported to the police for hate speech crimes. Danish political spaces are dominated by tests of loyalty: the requirement of Muslims to pledge their allegiance to the Danish constitution over and above the Qur'an; the establishment of legal criteria to restrict Danish citizens or residents from bringing spouses into the country from elsewhere in the world; and the need for all immigrants to show a stronger cultural connection to Denmark than any other country or entity. Without going into the debates about the publication of cartoons in the Jyllands-Posten, what is interesting is that one year after the original publication of the cartoons a video was aired in the Danish media that showed youth members of the Dansk Folkeparti engaged in a contest to draw pictures that insult Muhammad. Whilst the government roundly condemned the video's contents, a group named 'Defending Denmark' claimed that they had made the video to expose the extreme right wing associations of the party and its ongoing vitriol against Muslims and Islam. More recently, Lars Loekke Rasmussen has joined in the debate about Muslims and Islam by asserting that the 'face veil' has no place in Denmark. Other similar assertions and ideas can be seen in Austria, Belgium, France, Italy and Switzerland amongst others.

\section{Inferring Islamophobia}

In each of these settings, the prescriptive multicultural socio-political model is seen to be in crisis. Not just in crisis, but in each setting Muslims and Islam are implicated as agents for blame with debates and discussions ongoing in both 
the left and right of the political spectrum. For the right, it is easier for voices and organisations to elaborate on their thinking and ideologies. Not so however for the left. Historically, those from within the left have been at the forefront of combating discrimination and prejudices and so are seemingly horrified by the populism of the right's what might be deemed racist ideologies. But as can be seen emerging across the European landscape, multicultural tolerance and the respect of differences has, as Kymlicka warned, its limits. As Slavoj Zizak recently put it, today's tolerant liberal multiculturalism requires an experience of the Other that is deprived of its Otherness; describing it as the requiring of an experience of the decaffeinated Other (Zizak 20II). This can be clearly seen in the consensus communicated by Merkel, Cameron and Sarkozy. But so too can it be seen in the more overt and chilling rhetoric and discourses of the far-right, the neo-Nazis, of Breivik even. It would be nonsensical to imply that Merkel et al were the same as Breivik and his ilk, but what is evident is the notion that multiculturalism is presenting a threat to Europe and its individual states. At all levels, this is then impacting and influencing the political ideas and ideologies emerging from both the left and right of the traditional political divides.

Because of this, the social, political and policy trends emerging across the different states is new and untested in Europe. The banning of the face veil in France and Belgium and the banning of the building of minarets in Switzerland are seeming evidence of this. Elsewhere, similar policy developments are either awaiting implementation or are under ongoing consideration. How these develop and what impact they might have on the social, political and policy spaces of these different multicultural states - and on the notion of multiculturalism more widely - is as yet unknown. But what is clear is that underpinning the perceived crises of multiculturalism - and the 'problems' attributed with these - is that Muslims and Islam are being inculpably blamed and targeted. As the Commission on British Muslims \& Islamophobia noted almost a decade and half ago, not only was the hostility and hatred towards Islam and Muslims becoming "more explicit, more extreme and more dangerous" (CBMI: p. I) but so too were "organisations and individuals known for their liberalism and anti-racism [being seen to] express prejudice against Islam and Muslims" (CBMI: p. I5). It added: "...What is new [about Islamophobia] is the way it is articulated by those sections of society who claim the mantle of secularism, liberalism and tolerance...They preach equality for all, yet turn a blind eye to the fact that this society offers only unequal opportunities for Muslims" (CBMI: p. I5). Interestingly, this was being noted around the same time that Kymlicka was issuing his warning of the 
possibility that liberals in the multicultural setting will have to 'learn to live' with what they might believe to be 'illiberal' cultures, practices, values and so on.

\section{Understanding Islamophobia}

Islamophobia is a relatively new word for a relatively new concept; it was first used in print in its contemporary guise little more than twenty years ago. In this time, the term has been changed, manipulated, contested and dismissed in equal measure. Given its relative newness, some argue that Islamophobia or any other form or manifestation of anti-Muslim and anti-Islam hatred - is little more than a legitimate and rational response to the events of II September $200 \mathrm{I}(9 / \mathrm{II})$ and other similar events that have punctuated the decade of urgent history that has followed those tragic events. But as the landmark publication of the highly determinative and influential 1997 report from the Commission on British Muslims and Islamophobia (CBMI) highlighted, Islamophobia was distinctly not a post-9/II phenomenon. Islamophobia existed as much on the Io September 200I as indeed it did on the I2 September 200I. As the European Union Monitoring Centre on Racism and Xenophobia (EUMC) noted in its report on Islamophobia across fifteen European states following the attacks on New York and Washington, "Much of what occurred post-September II drew heavily upon pre-existent manifestations of widespread Islamophobic and xenophobic attitudes" (Allen and Nielsen 2002). It went on, 9/I merely "gave a pre-existent prejudice a much greater credibility and validity” (Allen and Nielsen 2002: 42).

There can though be little doubt about the significance and impact of 9/II and the way in which similar incidents since have continued to shape and determine how not just Islam and Muslims have been perceived, but more so the phenomenon of Islamophobia. At whatever level - national, political, institutional, community - the legacy of $9 / \mathrm{I}$ is never far from view and this is true of the contemporary European landscape as also North America and elsewhere. So too is there little doubt about the way in which $9 / \mathrm{II}$ and its legacy has fed the growing spectre of Islamophobia and with it, the rising incidence and proliferation of anti-Muslim hate crimes. Without the past decade - and not because of it, it has to be stressed - it is right to question whether the atrocities committed by Breivik would ever have taken place. Yet this same decade has been one where the very notion of Islamophobia - at times, even the merest recognition - has been routinely derided and dismissed, rarely if indeed ever being given the 
credence and seriousness of concern that such a dangerous phenomenon clearly deserves. Perceiving Islamophobia in the way that it has for the past decade has allowed for detractors and those who simply do not care to make simplistic assumptions: stop the terrorism and the Islamophobia will stop also. Sadly, such simplistic views are far from helpful, not least because the thinking and rationale underpinning them is flawed.

It would be wrong to suggest that nothing has been done to try and counter Islamophobia. In some countries, different legislative measures and policies have been implemented, various political debates have been undertaken and a number of Europe-wide reports have been commissioned amongst others. So too have other initiatives been established, by Muslim groups and organisations, by other faith groups and communities concerned by the rise in religious-driven hatred and hostility, and by those who campaign for greater equality and for the protection of human rights. Others too have been receptive to the threat of Islamophobia. Whichever way one reflects upon the outcomes and events of what began with the publication of the CBMI report and duly accelerated by 9/II, it cannot be argued that the language, discourse, notion and concept of Islamophobia has failed to acquire a contemporary British, European and global relevance: the latter emerging in particular following the debates around the 'Ground Zero' mosque and the proposed burning of the Qur'an by the American Christian minister Terry Jones, both in 2010.

There would also appear to be a concurrent process being played out, where despite Islamophobia either discursively or conceptually becoming increasingly referenced, referred to and spoken about, there also appears to be a distinct lack of clarity and understanding about Islamophobia: about what it is, what it is not and what can be done about it. The asking of these questions so far has resulted in further contestation and confusion: about definition, usage, meaning and ownership. There remains therefore a clear need for further investigation not least about what is 'Islamophobia'. Improving understanding about Islamophobia cannot merely be a process of constructing simplistic definitions that allow easy criteria that hope to identify whether or not something is Islamophobic. If defined too broadly, then Islamophobia will escape censure where meaningless definitions and conceptualisations will become over-inflated and remove any concretised or empirical grounding. If the definition is without grounding, then discourses that would otherwise be regarded as socially unacceptable will begin to attain social legitimacy as well as political agency. Through political agency, Islamophobia might then become implicitly shrouded beneath the cover of 
nationalism and national belonging for instance, in preference of explicit or overt manifestations of racism or Islamophobia, even though the resultant consequence or impact might be very much the same. Likewise, if overly simple definitions and conceptualisations are put forward, overly simple - and overly inadequate solutions will ensue, culminating in a similar situation to that which has already been established. In addition, both the definition and purported solution obscures the specificity and complexity of the phenomenon; undermining, hindering and even negating the problem whilst supporting further contestation.

Recognising the complexity of this, recent research has put forward the suggestion that Islamophobia is a threefold ideological phenomenon, one where Islamophobia becomes conceived and evident in the form of systems of thought and meaning as well as through systems of signifiers or symbols which pertain to influence, impact upon or inform the social consensus about 'the Other' (Allen 2010). Employing this model, Islamophobia is not necessarily restricted to any specific action, practice, discrimination or prejudice but instead gives meaning to that which is widely accepted as natural and normative of Muslims, Islam or both. As Clarke explains in terms of the function of ideology, this "creates a form of order, who we are, or perhaps more precisely who we are not, by the stigmatisation, marginalisation and intolerance associated with this" (Clarke 2003:15). On the basis of this 'form of order', so discrimination and prejudice can be duly founded upon inaccuracies, misunderstandings and misrepresentations as indeed it can upon accurate, correctly understood and true representations of Muslims or Islam: all become seen to be 'normative truths' whether that be the case or not (Allen 2010). If a 'form of order' is therefore created that establishes Muslims and Islam as being 'who we are not', it would appear that this would be Islamophobia.

If Islamophobia is ideological, and thereby the first component of the broader phenomenon, then it must function as such, where ideological content meaning about Muslims and Islam - must be disseminated to the public and private spaces: through a vast range of different actions, utterances, images and texts that are recognised and digested as meaningful by its recipients. In this instance, both dissemination and reception are as equally important. To achieve this, the second component of Islamophobia is the 'modes of operation' through which meaning is sustained and perpetuated. It is imperative to stress though, that modes of operation are not equitable with the symbolic forms through which Muslims and Islam are either identified or recognised. These modes and strategies nor are neither concretised nor unchanging, and so new modes and strategies 
may at some stage appear whilst others may similarly disappear, be replaced or substituted: this can occur also in different geographical, cultural, social and so on settings. Neither the modes nor strategies are in themselves ideological: they only sustain ideological meaning, whether intentional or otherwise. The final component of Islamophobia is exclusionary practices: practices that seek to disadvantage, prejudice or discriminate against Muslims and Islam in social, economic and political spheres. Exclusionary practices must also include the subjection to violence as a tool of exclusion. Interestingly, these are all things that prescribed multiculturalism sought to eradicate.

\section{Making it 'reasonable'}

In many ways, the ideologies of Breivik and others from the far-right milieu are far from extraordinary. This is not to say that the atrocities committed by Breivik are not extraordinary: they are, and must serve as a timely reminder of the very real threat that the 'lone wolf' extremist presents to our security in today's Europe. What is extraordinary however is the resonance that the ideologies of the political mainstream - the centre left and right - has in relation to multiculturalism with those on the far and extreme right. But even acknowledging this contributes towards the relative smokescreen that is being created by multiculturalism. In many ways, the crises of multiculturalism are mere smokescreens for what many are seeing as the 'problems' attributed to the presence and visibility of Islam and Muslims in Europe and the Islamophobia which underpins this. Zizak again provides some insight. Referencing the French fascist intellectual Robert Brasillach, Zizak reflects on Brasillach's 'reasonable antisemitism':

"We don't want to kill anyone, we don't want to organise any pogrom. But we also think that the best way to hinder the always unpredictable actions of instinctual antisemitism is to organise a reasonable antisemitism" (Zizak 20II).

In today's Europe it might be argued that something similar is occurring but in terms of a 'reasonable' Islamophobia. Having upheld the need for minority rights, for equality, justice and welfare support as being necessary values of our European heritages and histories, increasingly we are moving away from these - rejecting them even - to endorse policies that are discriminatory, divisive and 
damaging. To make them more palatable - to differentiate them from the less palatable versions of the far-right - the mainstream politicians and others speak about 'problems', implied enough for most to be able to understand and accept, to make them appear legitimate, rational and as Brasillach might have put it, 'reasonable'.

If, as the discourses and rhetoric suggest, we are moving into an era that goes beyond multiculturalism - post-multiculturalism according to Steven Vertovec - then it is essential that we do not lose sight of the values that made Europe embrace multiculturalism and its politics. Reject multiculturalism and banish the 'M-word' from our lexicon if necessary; Europe can cope with that. But in doing so, let us not reject and banish the values that were behind why we once embraced multiculturalism and its socio-political policies and practices. More importantly, it is essential that this does not allow for a space to be created where the antithesis of multicultural values are allowed to ferment and manifest in the form of a 'reasonable' Islamophobia. The 'crises' of multiculturalism will not be solved by endorsing Islamophobia, whether from the right, left or centre of the political spectrum. Despite the assertions of Breivik and others from within the far-right milieu, it is not the presence of Muslims and Islam in Europe that presents the greatest threat. Instead, it is the rejection and loss of the values that are at the very heart of multiculturalism that presents the greatest threat to the future of Europe: to who we are, what our values and culture might be.

\section{References}

Allen, C. and J. Nielsen (2002). Summary report on Islamophobia in the EU after II September 20or. Vienna: European Monitoring Centre on Racism and Xenophobia.

Allen, C. (2005). 'From race to religion: the new face of discrimination,' in Abbas (ed.) Muslim Britain: communities under pressure. London: Zed Books.

Allen, C. (2007). 'Down With Multiculturalism, Book-burning and Fatwas', Culture and Religion, 8: 2, I25-138.

Allen, C. (2010). Islamophobia. London: Ashgate.

Alund, A. and Carl-Ulrik Schierup, C.U. (1991). Paradoxes of multiculturalism. Aldershot: Avebury.

Barry, B. (2002). Culture and equality. Cambridge: Harvard University Press.

Bhattacharyya, G. (1998). 'Riding multiculturalism' in David Bennett, Multicultural states: rethinking difference and identity. London: Routledge.

Carle, R. (2005). 'Demise in Dutch multiculturalism,' in Society, Vol 43, no. 3: 68-74. 
Clarke, S. (2003). Social theory, psychoanalysis and racism. London: Palgrave.

Joppke, C. (1999). Immigration and the nation-state: the United States, Germany and Great Britain. Oxford: Oxford University Press.

Kelly, P. (2002). Multiculturalism reconsidered. Cambridge: Polity Press.

Kymlicka, W. (1989). 'Liberal individualism and liberal neutrality', in Ethics Vol. 99, No. 4: 883-905.

Kymlicka, W. (1995). Multicultural citizenship: a liberal theory of minority rights. Oxford: Oxford University Press.

Taylor, C. (1994). 'The politics of recognition', in Gutmann, A. (ed.) Multiculturalism: explaining the politics of recognition. Princeton: Princeton University Press.

Modood, T. (2005). 'Remaking multiculturalism after 7/7'. In openDemocracy [cited 29 September 2005]. Available from http://www.opendemocracy.net/debates/article.jsp?id $1 / 42$ \&debateid $1 / 4124$ \&articleid $1 / 42879$.

Modood, T., Triandafyllidou, A. and R. Zapata-Barrero (eds.) (2006). Multiculturalism, Muslims and citizenship: a European approach. London: Routledge.

Modood, T. (2006). 'British Muslims and the politics of multiculturalism' in Modood, T., Triandafyllidou, A. and R. Zapata-Barrero (eds.) Multiculturalism, Muslims and citizenship: a European approach. London: Routledge.

Parekh, B. (2000). The future of multi-ethnic Britain: report of the Commission on the Future of Multi-Ethnic Britain. London: Profile Books.

Scuzzarello, S. (2010). Caring multiculturalism: local immigrant policies and narratives of integration in Malmo, Birmingham and Bologna. Lund: Lund University.

Young, I. (1990). Justice and the politics of difference. Princeton: Princeton University Press.

Zizak, S. (20II). Liberal multiculturalism masks an old barbarism with a human face, Guardian (3 October 2011). 
Conclusion 



\title{
CHAPTER I 2 \\ Ethnic-Religious Intersections and New Multiculturalism
}

\author{
Johan Leman, Erkan Toğuşlu and İsmail Mesut Sezgin
}

\section{Which place for religion in 'new' multiculturalism?}

What we have learned from the chapters in this book is that in Europe today we have started living in an epoch in which the post-immigrant's 'new' ethnicity expresses itself very often in religious emblems, and the indigenous ethnicity looks for an expression through regional nationalisms and ethnicized and culturally essentialized secular religion. In such situations, indigenous ethnicity may claim a first-born's right on a particular territory, underpinned by values and standards unlike that of the religiosity on which the post-migrant communities rely. In both cases this leads to all kinds of constructions, and it is here that the globalization has created a new context in the present.

Comparing similarities and differences between indigenous and immigrant ethnogenesis, Leman predicted that "the development of the multi-ethnic (or multicultural) societies that arise from all kinds of immigration movements will, in the long run, be chiefly determined by the way in which structures and sedimentations of different religious institutions, which are imported by these movements, can continue to be used as a mobilisation factor" (1998: 160).

In the three cases, immigrant, post-migrant and even non-migrant ethnic reactivity, "almost anything and everything is possible, as long as no falsehoods are told that are too obviously refuted by common knowledge and as long as the adversary is not too strong" (Roosens 1989: 16I). From the 1990s on, global and trans-border embeddedness has had the consequence that there is more 
trans-border streamlining, both in the post-migrantism, and in non-migrant identification mobilizations, in thought and in practice. In our book we focussed on post-migrant (Part I) and on anti-migrant, mostly anti-Islam ethnicity (Part II).

\section{Post-migrant ethnic creativity}

The chapters in our Part I have shown a variety of answers and constructions among young new generations, nourished by the impact of the internet and social media, online practices which however are not in complete discontinuity with the offline practices of young people. Being Muslim or not-Muslim fundamentally does not make any difference in the application of the practices, but the streamlining that follows from it may promote some emblems more than others related to cultural preferences and to culturally prescribed behaviour. From all the findings in Part I we see how transborderly mainstreamed secular adaptation, loyalty to the practices of parents and grandparents, and genuine neo-fundamentalist glocal creativity can all be met in one locality in today's Europe, in some cases with multiple expressions in one family or even in one person.

Drummond, at the beginning of the 1980 s, discussed 'creolization' as a complex identity construction process which was not based solely on 'double identification'. He explained that the staying together of people from a variety of communities could be the beginning of all kinds of mixtures, most clearly though not exclusively, on the basis of mixed marriages. These mixtures gradually lead to an ethno-cultural continuum. As Drummond argued, "The 'elementary structure' of such a cultural system is not an isolated proposition, but an intersystem - the pragmatic residue of persons seeking to define their identity vis-à-vis one another. ... A cultural continuum, like a linguistic continuum, may be identified by inserting arbitrary boundaries within a transformational series" (1980: 370). As we see from our findings, such a new style continuum as proposed by Drummond, be it in a completely different context, is only one pattern in the complex cluster of practices that is made possible in today's Europe. By the end of the 1990s, Aishe Caglar discovered a more general 'European' postmigrant phenomenon when she discovered that "a growing number of people define themselves in terms of multiple national attachments and feel at ease with subjectivities that encompass plural and fluid cultural identities" (Caglar 1997: 
169). Such 'hyphenatization' referred to the fact that the prevailing socio-cultural praxis of the host country exerts a clear influence over the immigrants' view of their culture of origin.

What we learned from such authors, and from many other researchers (Leman had already described the phenomenon by ending his research on Sicilian immigrants in Belgium on a similar note: see Leman 1987), was that the processes which find their roots in migration are not unilinear ones and are at the beginning of many variegated creative practices. What has become more impressive nowadays than in earlier years is the impact of the global, the internet, the social media and various forms of more accessible mobility on the creation of current creative practices. That is what the authors in our Part I were able to illustrate perfectly, applying it in most cases (but not all) to post-migrant Muslims.

During the I990s, faith-based organizations created a strong foundation in most immigrant communities. The second generation young adults changed the dynamics of these organizations which, in former times, focussed on the countries and community cultures of the countries of origin a great deal more. Some new dynamics had begun to take shape which were coupled with a shift in emphasis to the countries of destination. First, these faith-based organizations adopted a clearer profile, profiling those communities which changed from immigrants to citizens as the supporting axes of an internal pluralism inside the post-migrant communities. Secondly, and occurring simultaneously, they began much more intense cross-border relations with similar communities in other countries which adopted similar positions in the interpretation of their religion.

Networking geared towards easier and less expensive transport modalities, as well as the internet, has become a very typical characteristic of the current faith-based organizations. The impact on their members' feelings of trans-border identification is obvious, so also is its impact on glocal neo-fundamentalisms (cf. Robertson 1993: 174).

\section{Indigenous anti-migrant ethnic re-activity}

The trans-border character of the faith-based communities and the strong visibility of glocal neo-fundamentalisms imply that some segments of the indigenous population perceive this presence to be highly invasive. One can observe the feeling of xenophobia that is latent therein. Some more militant 
people attempt to sustain this sentiment by offering it a megaphone. They then present certain historical conflicts with the Muslim world, or conflicts elsewhere in the world, as a threat to a native population's own country today. Islam becomes presented as an invader. This may lead for some, sometimes very secular people, to an aggressive, fundamentalist ethnic-cultural Christianity which not only needs to be protected but which offers the 'moral capital' to pre-empt and cut off the Islamic 'other'. This is what some chapters in Part II developed, with a final reflection in Allen's chapter II.

In this logic, and in terms of ethnicity, a given society's indigenous side must then be protected and preserved as a mixture of original local emblems and values, and even in terms of the idea of Western Christendom itself. For such militants, it is important therefore to attempt to understand where in other countries similar movements arise. But it is a fact however that the local ethnic colouring is difficult to transfer into other cultural contexts in other countries. Still there remains an ethnic-cultural 'Christian factor' that one can appeal to, although it is mostly used among people who are no longer faithful to Christianity or are of a very secular set. So, such trans-border mobilization may be more difficult than among 'post-migrant faith-based communities' where the religious glue is stronger, and it leads to initiatives of 'lone wolf' militants and a variety of smaller transborderly organized co-operations with an anti-islamization and antimulticulturalism agenda.

The non-migrant post-secular mobilizations at Europe's surface are occupied mainly by nationally-known charismatic figures. They do not associate easily among themselves in a common, more global transborder European anti-Islam project, but find one another in a militant anti-Europe attitude.

\section{Post-secular and border widening processes (and counter-movements)}

The development that seems most striking is the tension between secular and post-secular. It is the ethnic-cultural and religious developments that interested us in our book.

For a description of what constitutes the secular, we look to authors such as Habermas (2008) and Taylor (2007), while accepting the criticism that Asad (2003) expresses in mentioning how the particular power relations which undergird the communities often result in situations where there is no 
objective, respectful dialogical space which is conducive to religious exchange. Continental Western Europe (i.e. most of the host countries in this book) has created a tradition of the secular, with gradated differences between the various countries, seen as a neutral, secular public space which remains separated from other areas, namely the pre-eminently private domain. People in public spaces, especially within certain prescribed roles and positions, should consider their private characteristics, which are framed in terms of religion, belief, gender, as something they should hide.

The discussion that may follow on from this is that not everything in the public sphere can be experienced as being equally relevant, or that not everything everywhere is experienced in the same way in either the private or public sphere. In addition, some also defend pluralism and neutrality in a globalizing world which consists of group characteristics which may be expressed in terms of equivalents. These last will claim that if these expressions are not accepted, the secular can be said to constitute itself as an ideology which displaces other ideologies.

Today we see that the Continental Western European concept of the secular is being very heavily criticised by young post-migrant Muslims. In order to try to understand this criticism it is prudent to also take into consideration some processes that are related to the globalization. These general processes may help to frame the processes.

A first consideration is that religion is seen by many post-secular feeling people as a buffer against new anxieties. According to Martin Riesebroth secularization and religious revival go hand in hand. Scientific advancements, especially deriving from medicine, have meant that today human control over its life span has increased. The welfare state has reduced the vulnerability experienced by people from lower class backgrounds. Political power has become closer to common human beings. However, with the rise of scientific power and of human autonomy a new powerlessness has arisen in the form of possible threats of ecological catastrophe or fears of the sudden rise of authoritarian regimes and irrational movements led by charismatic leaders. Many people also feel that their family life has become destabilized by the excessive pressures of social mobility. The "destabilizing effects of Western modernization have ... paved the way for a resurgence of religious modes of crisis prevention and management," concludes Riesebrodt (2003: 108). After all, "historically, it has mostly been through religions that the chaotic or potential crisis has been culturally transformed into the semblance of cosmos" (Riesebrodt 2003: 106). 
This may be one of the elements that explain the omnipresence of religious loyalty, as developed by some authors in Part II.

AndyetRiesebrodtfollowsthe reasoningofRobertson(1992;2003). Heobserves in these phenomena the origin of contemporary religious fundamentalisms. But the question is whether a reaction to these forces necessarily and invariably leads solely in the direction of local fundamentalism. Can one not imagine that there are people who do not want to rely on any fundamentalism, but prefer support in seeking a wider and more democratic religious and social network? Instead of highly localized smaller communities, of the fundamentalist type, one may also obtain translocal religious networks of such a magnitude that one can assume that they are not on the edge of society, but have the ability to act decisively to reshape the society in which the common people live. They are looking to succeed through their own voices and deeds, to find a form of recognition in a system of meaning that would otherwise be insufficient or unrepresentative of their own social and cultural capital. This variety of processes brings us to some developments that we could read in Part II.

The theoretical reflections, also in Part II, may bring a second field of considerations. Can religion not have become an alternative for economic dominance? Roland Robertson wrote that "there has, in effect, been a detachment of the economic from the other dimensions of globalization.... Overwhelmingly globalization is now seen as a primarily economic phenomenon" (Robertson 2003: I23). His reasoning is that originally this had been initiated as a corrective to include localized "anti-global" fundamentalisms, not least those of a religious nature, but that "anti-global movements have inexorably become part of the globalization process itself” (Robertson 2003: II4). But Robertson also ended his statement by reinforcing the declarations made previously by Riesebrodt. What we perceive to be a normal attitude among religiously-minded people who find a place in a world that is highly susceptible to processes from science and politics may also be seen as an inevitable behavioural non-science-based reaction of people who are, in fact, anti-global in the first instance. But in the second instance, the trans-border and post-secular reflexes found in these religiously minded people may have become a form of participation from their part in the global arena.

We might think, therefore, that the process of trans-border religions should be seen as a logical consequence of full participation in the global sphere. As Ninian Smart observed, it is "the present state of the world - one of intense globalization - [that] has its effect on religion" (Smart 2003: I24). Religion should not simply 
be seen as a reactive agent, but as a co-constitutive one. "One of the great myths is that religion is always the same: that an evangelical from Missouri has the same values as the apostle Paul, for example" (Smart 2003: 124). But religions are constantly changing, and this becomes perhaps clearest in a globalizing world. This puts pressure upon secular values and creates openings to post-secular thought and to post-secular action being taken.

What is already a process that has its sources in the post-migrant processes, mainly among post-migrants of Islamic provenance, may become reinforced by the input nowadays coming from new, even first generation, migrations that support the trends of trans-border mobility and transnational belonging. The mobility, for example, of Indian religions is already quite well demonstrated, of Hinduism (Vertovec 2000), of Sikhs in Europe (Jacobsen and Myrvold 20II) and of global Jain diaspora (Jain 20II). It pushes policy makers to reflect on 'politics of difference' (Modood 2007), which may accept some collective and public identities of religious groups and protect them against a too secularist bias towards them, or it opens the door for some 'multidimensional pluralism' (Connolly 2005). We can use Fraser's words: new migrations are transnationalizing the public sphere (Fraser 2007). Such questions were all treated in Part II of our book, where at the same time the question of multiculturalism and its tension between factual and 'normative' was treated. We will come back to the theoretical as well as to the practical reflections.

In all this, the WWW space has had more of an impact than any other element associated with globalization. "Web space leads to complex articulations in the possible identification processes of the social selves, but it also creates new opportunities for 'us-consciousness', creating new loyalties and borders, and empowering the perceptions of the Self" (Leman 2009: 195). Levy (1995) has pointed out that the three modalities important in this respect are: the de-territorialization of the here and now, the emergence of new spaces and new speeds which become mixed up with preceding ones, and a continuous interplay of the inside and outside. It is clear that the Web has streamlined and helped to foster the everyday lives of immigrant faith communities. It also promotes exchanges between anti-multiculturalist militants and members of such militant Islamophobic trans-border communities of non-immigrants whose contribution would normally be overlooked. The Web can be said to homogenize only in part, and even then mainly within each of their individual trans-border communities, while the antagonisms with the "Other" tend to strengthen, deepen and broaden fault lines rather than diminish them. Within each trans-border community, it 
"centralises and structures information and is a tool of empowerment" (Leman 2009: 200).

\section{The process character in Europe's new multiculturalism}

Religion as well as ethnicity creates "imagined communities" (Anderson 1983). Both religion and ethnicity can create and develop a dynamic of an increasing sense of an all-encompassing global community in the context of globalization, but it is a slow process. A multicultural setting is not a 'be all and end all' panacea for a stabilized society. In such a complex multi-layered society people continuously have the capacity to be 'affected' (cf. Deleuze 1990: 93-95) from inside and outside. One may call it a process of differencing: 'becoming different' as 'deferred in time and space' (Derrida 1982: 8-9). It may create a lot of new 'idealities' (Derrida 1967), relating to always 'new' developments stemming from inside and outside one's own community. Practices may remain partially integrated in a field of former social-cultural practices and become extended to new practices coming from a different proposed 'ideality', or even coming from other countries that are part of the trans-border realities. Group changes can lead to new identifications (Iborra 2005), and these changes may take several forms depending on the strength of the bond with the trans-border community. Vis-à-vis the processes of change and 'differencing' of cultural meanings, we should understand (and that is the sense of Mečiar's reflections in chapter 4 of Part I) that the challenge for future research will be that we cannot impose our ethno-centric Western categories on an understanding of the 'emic' content of immigrants' narratives. It means that increasing religious diversity each time with its own different internal dynamics brings us into a post-secular society frame. It does not invalid the secularization theory, but invites us to understand that a tolerant coexistence between different religious communities in a context of growing social inequality will become less obvious, since religion will become more important in shaping identities in some situations.

From Murat Sevencan's large-scale research (see chapter 9 in Part II), we learned that choices and decisions may be influenced by shifting the salience of a particular identification for a person. In Europe, religion, with its ethnic and identitary connotations, is present in most countries, as a culturescape biased by Christendom. Religion in general, not just Christendom, transcends as the first and most solid life-view in Europe geographical and political boundaries, even for Muslims and other religions. We can indeed not conclude from the 
data that religion will never have some mobilizing power. But currently, it does not mobilize vis-à-vis others in the sense of relations with other countries as a marker that is more important than nationality. So, we are somewhere in between an 'it is not' situation and an 'it is not ruled out in the future' one. There is another important life-view, namely a modern-political life-view. This lifeview formulates the identity categories with respect to the political perception. One can associate this structural life-view with both national and local identity. Local identity is the nearest alternative to a national one. Nowadays in Europe, we see how local identities are the most challenging. Sub-national, nationalistic and regional, identifications are less present 'overall', but where they are they can become significant rivals of national identities. Still different from both former identifications is the very paradoxical situation that personal individualism, i.e. a modern-intellectual life-view constructed from internal reasoning, is also an overall present value. It can be personal as well as supra-national. It is not a challenge for national identity. Moreover, one can safely say that this secularglocal identity also has a distance from the post-secular religious glocal one as well.

The above, with its three important life views that are all present in citizens' lives, is the context that makes it understandable that in Europe, a territory with multiple identifications for one and the same individual, there may be moments and places where nationalisms, religious transnational fundamentalisms, personal individualisms are present when national identifications also remain very strong. It is the source of a continuous uprising of new social-cultural and ethnic-religious processes that interfere with the already existing ones.

\section{Practical political challenges}

The processes as described here above offer some practical challenges for the state. It is the mission of a democratic state not to reduce the sources for the shaping of identities by limiting the diversity of voices and opinions within the public discourse, so some solution should be found to reconcile this need for religious selfexpression with respect for the secular. But it is also true that it does not mean that religion should be over-emphasized or over-politicized as a source of identity as if it may be the principal reason for immigrants' actions. What should be found in European societies, in the logic of these reflections, is a new sane balance between ethnic and religious belongings and the secular common space.

In chapter Io (Part II), we read about a plea for a 'transformative accommodation'. As Nimni writes, whether religious or secular, difference-blind 
equality defaults in the dominant practice and excludes and alienates minorities. The exemplary image of a "normal" member of the dominant group may remain blind for acceptable, democratic expressions coming from minority people. Very probably, this can no longer be legitimized. A failure of secular legal systems is to remove from consideration religious motivations and practices of groups in plural societies that do not belong to the dominant cultural-religious, even secular majority. If we want minority people, with a different religious background, to see themselves as recognized in their identity and way of life, there is a step to be taken in the direction of some religious legal pluralism for private matters that do not change the existing secular compromise. The debate that opens with such reflections is about factual versus prescribed multiculturalism.

We presented our book under the title 'Europe's New Multicultural Identities'. In the first Part we presented research findings that showed what these new multicultural identities are about in various places at the European Continent. Post-migrant and re-active anti-migrant identifications and belongings had an important place in the second Part. We approached all these phenomena as manifestations of identities in a plural post-secular Europe. In our concluding chapter, we see these manifestations of identities as processes framed by ethnicreligious intersections, and call it Europe's new multiculturalism. It is not the end of a process; it will also in the future continue to pose a lot of new theoretical and political challenges.

\section{References}

Anderson, B. (1983). Imagined Communities: Reflections on the origins and spread of nationalism. London: Verso.

Appadurai, A. (1976). Modernity at Large. Minneapolis: University of Minnesota.

Asad, T. (2003). Formations of the Secular. Christianity, Islam, Modernity. Stanford University Press.

Caglar, A.S. (1997). 'Hyphenated identities and the limits of culture', in Modood, T. \& P. Werbner, The politics of multiculturalism in the new Europe. London: Zed Books, pp. 169-185.

Castells, M. (1996). The rise of the network society. Oxford: Blackwell.

Connolly, W.E. (2005). Pluralism. Durham and London: Duke University Press.

Deleuze, G. (1990). Expressionism in Philosophy: Spinoza. New York: Zone Books.

Derrida, J. (1967). La voix et le phénomène. Introduction au problème du signe dans la phénoménologie de Husserl. Paris: P.U.F. 
Derrida, J. (1982). Margins of Philosophy. (Translated by Alan Bass). Chicago: University of Chicago Press.

Drummond, L. (1980). 'The cultural continuum: A theory of intersystems', $M A N$, is (2), 352-374.

Habermas, J. (2008). Notes on a post-secular society, in: http://www.signandsight.com/ features/1714.html. Translated from a paper written in German and published in Blätter für deutsche und internationale Politik (April 2008).

Iborra, A. (2005). 'Beyond Identity and Ideology: Processes of transcendence associated with the experience of conversion, Culture \& Psychology. Vol. 2 (I): 89-100. London: Sage publications.

Jacobsen, K.A. and K. Myrvold (eds.) (2011). Sikhs in Europe. Migration, identities and representations. Farnham: Ashgate.

Jain, P.C. (2011). 'Exploring the Global Jain diaspora,' in Jayaram, N. Diversities in the Indian Diaspora. Nature, Implications, Responses. New Delhi: Oxford University Press, I55-172.

Leman, J. (1987). From Challenging Culture to Challenged Culture. The Sicilian cultural code and the socio-cultural praxis of Sicilian immigrants in Belgium. Leuven University Press.

Leman, J. (1998). The Dynamics of Emerging Ethnicities. Immigrant and indigenous ethnogenesis in confrontation. Frankfurt a. Main: Peter Lang.

Leman, J. (1999). 'Religions, Modulators in Pluri-Ethnic Cities: An Anthropological Analysis of the Relative Shift from Ethnic to Supra-Ethnic and Meta-Ethnic Faith Communities in Brussels,' Journal of Contemporary Religion, vol. I4, nr. 2, 217-231.

Lévy, P. (1995). Qu'est-ce que le virtuel?, Paris: La Découverte.

Modood, T. (2007). Multiculturalism. Cambridge: Polity Press.

Riesebrodt, M. (2003). 'Religion in Global Perspective', in Juergensmeyer, M. (ed.). Global Religions. Oxford University Press, 95-109.

Robertson, R. (1992, $\left.2^{\text {nd }} 1993\right)$. Globalization. Social theory and global culture. London, Newbury Park, New Delhi, Sage Press.

Robertson, R. (2003). 'Antiglobal Religion,' in Juergensmeyer, M. (ed.). Global Religions. Oxford University Press, IIO-I23.

Roosens, E. (1989). Creating Ethnicity: The process of ethnogenesis. Newbury Park: Sage publications.

Smart, N. (2003). 'The Global Future of Religion,' in Juergensmeyer, M. (ed.). Global Religions. Oxford University Press, I24-I3I.

Taylor, C. (2007). A Secular Age. Cambridge: The Belknap Press of Harvard University Press. Vertovec, S. (2000). The Hindu Diaspora. Comparative Patterns. London \& New York: Routledge. 



\section{About the Authors}

Dr Chris Allen is a Lecturer in Social Policy in the Institute of Applied Social Studies at the University of Birmingham. Having completed his Arts \& Humanities Research Council (AHRC) funded doctoral studies that explored the discourse and theory of Islamophobia, Chris has since gone on to work closely with the House of Lords Select Committee on Religious Offences, the Centre for European Policy Studies, the Equality \& Human Rights Commission, the European Commission on Security Issues in Europe and the Greater London Authority amongst others. At a pan-European level, he has been commissioned to work for the European Union Monitoring Centre on Racism \& Xenophobia, co-authoring the summary report on Islamophobia in the EU after 9/Ir. A recent publication: Islamophobia (Ashgate, 2010).

Address: The Institute of Applied Social Studies, University of Birmingham, Room 92 I Muirhead Tower, Edgbaston, Birmingham Bis 2 TT England; +44(0) 7940 53769I; c.allen.2@bham.ac.uk; http://www.iass.bham.ac.uk/; http:// www.iass.bham.ac.uk/staff/Allen.shtml

Dr Cüneyd Dinç is an Assistant Professor of Sociology at Süleyman Şah University, Istanbul. His current research areas focus on the Turkish Welfare Regime, the Turkish Party System, Post Secularism, Post-Islamism and consumption. Recent publications include Sozialstaat als Produkt einer Staatselite - Das türkische Wohlfahrtsregime in südeuropaischem Vergleich [Welfare State as a Product of a State Elite - The Turkish Welfare Regime in a South European Comparison] and articles in Istanbul Edebiyat Fakültesi Sosyoloji Dergisi and CEU Poltical Science Journal.

Address: T.C. Süleyman Şah University, Tuzla Leyla Dumankaya Kampüsü, Fatih Mah. Eski Ankara Asfaltı Üzeri, 34956 Orhanlı/Tuzla/İstanbul, Turkey. Mail: cdinc@ssu.edu.tr

Dr Frédérique Harry is a Lecturer in the Department of Nordic Studies at the University of Paris-Sorbonne where she has been a faculty member since 2006. Frédérique Harry completed her Ph.D in 20Io. Her research interests lie in the area of sociology and history of religion in the Nordic Countries, with a focus on 
associative and political milieus. In recent years, she has been developing several research projects on identities in the Germanic countries, the circulation of goods and objects, and the circulation of ideas and population after the Reformation in the same geographical area.

Address: frederique.harry@gmail.com

Dr Goedroen Juchtmans is a senior researcher with the 'Education and Lifelong Learning' unit at HIVA (Research Institute for Work and Society), KU Leuven, Belgium, and a research co-ordinator at the Interdisciplinary Knowledge Centre for Church and Society (IKKS, Antwerp).

Address: goedroen.juchtmans@kuleuven.be

Dr Vincent Legrand is a lecturer at the Universite catholique de Louvain (UCL). He holds a Ph.D in Political Science, graduated in Arab \& Islamic studies and dedicates his research to Contemporary Arab Studies. As a former adviser on Christian-Muslim relations at the Commission of Bishops' Conferences of the European Community (COMECE), he also does research on issues relating to Islam, Muslim communities in Europe and ChristianMuslim dialogue.

Address: vincent.legrand@uclouvain.be

Dr Johan Leman has an MA in philosophy, theology (O.T. exegesis), oriental philology and history, and social and cultural anthropology, from the KU Leuven. He is emeritus professor of social and cultural anthropology, and holds the chair at Gülen in intercultural studies (see gcis kuleuven), KU Leuven. He is a former chief of cabinet of the Royal Commissioner for Migrant Policy in Belgium (1989-1993), former director of the federal Centre for equal opportunities and the fight against racism in Belgium (1993-2003), and a former coordinator of IMMRC at Social Sciences in KU Leuven. He is currently the president of Foyer, an integration centre in Brussels (www.foyer.be). For a selection of research and publications see www.johanleman.be.

Address: johan.leman@soc.kuleuven.be

Dr Kathryn Lum is an anthropologist and Postdoctoral Research Fellow at the Migration Policy Centre, European University Institute, Florence. She is currently the coordinator of a project on Indian migration to the EU. Her main 
research interests are caste in India and the Indian diaspora, Sikhism and the Punjab, gender relations, and migration studies in Southern Europe.

Address: CARIM India, Migration Policy Centre, Robert Schuman Centre for Advanced Studies, European University Institute, Florence; www.migrationpolicycentre.eu; Tel: 0039055 4585 849; Kathryn.Lum@EUI.eu

Dr Marcel Mečiar is a Czech sociologist of Slovak origin who has been living in Turkey since 2009. After eight years of teaching and research at the University of Ostrava (200I-2008), he has continued his work as a lecturer at Yeditepe University in Istanbul. His broad research interests lie at the intersection of spatial sociology, historical sociology and the sociological theory of identity. $\mathrm{He}$ is particularly concerned with the social and discursive formation of identities, migration, immigrant adaptation and, in the realm of methodology, with discourse and narrative analysis.

Address: Yeditepe University, Faculty of Arts and Sciences, no. 723, Department of Sociology, 26 Ağustos Yerleşimi, 34755, Kayışdağı, Istanbul, Turkey. Email:marcel.meciar@gmail.com

Dr Ephraim Nimni is Reader on Nationalism and Ethnic conflict at Queen's University Belfast and in 2013-I4 Visiting Ikerbasque Professor at the University of the Basque Country. Born in Buenos Aires he studied at the Hebrew University, Jerusalem, Essex and Hull. Main publications: National-Cultural Autonomy and its Contemporary Critics (Routledge, London Series Innovations in Political Theory, 2005), The Challenge of Post-Zionism (London: Zed Press, 2003), Arabic translation by Ahmad Thabt, Tahadiat Ma Baad Al-Sahyonia, with an introduction by Mohammad Hashim, Cairo 2005, Editor of the first English translation of Otto Bauer, The Question of Nationalities and Social Democracy (Nationalitätenfrage und die Sozialdemokratie) with a foreword by Heinz Fischer, President of Austria (Minneapolis: University of Minnesota Press, 200I), pp. xv-xlviii, Marxism and Nationalism, Theoretical Origins of a Political Crisis, Pluto Press, London 1995.

Address: School of Politics, International Studies \& Philosophy, Queen's University Belfast Belfast BT 7 IPB, Northern Ireland, e-mail: e.nimni@qub.ac.uk

Dr Murat Sevencan received his Ph.D from Istanbul University in the Social Sciences Institute's European Union Programme. While working on his Ph.D, he worked as an instructor in quantitative and European based courses in several 
universities, and after obtaining his Ph.D he worked in Istanbul Aydın University's Political Sciences and International Relations Department as Assistant Professor. Currently, he is a member of the International Relations Department of Suleyman Sah University. His areas of interest mostly include national identity and national values formation. He has written several articles on the identity formation of the EU and also on the ideological polarization of Turkish polity. He is currently working on a method of constructing national identities quantitatively through Meta Contrast Ratio of Social Categorization Theory.

Address: msevencan@ssu.edu.tr

Dr İsmail Mesut Sezgin holds a degree in Political Science and International Relations from Marmara University, Istanbul. He is currently preparing a Ph.D about the relationship between religion and society. In particular he is researching religious definitions of responsibility and their effects in society. Before coming to Leeds Met he spent some time as a volunteer in different civil organizations. His research interests include, religion, Islam, Sufism, British Muslim identity, Christianity, moral responsibility and politics.

Address: ismailmesut53@gmail.com

Dr Erkan Toğuşlu is coordinator at the Gülen Chair for Intercultural Studies and Assistant Professor at the Interculturalism, Migration and Minorities Research Center at KU Leuven University. He received his MA and PhD in sociology from the Ecole des Hautes Etudes en Sciences Sociales (EHESS) in Paris. His research focuses on transnational Muslim networks in Europe, the emergence of Islamic intellectuals, interfaith dialogue, the debate on publicprivate Islam, the nexus immigration and religion.

Address: erkan.toguslu@soc.kuleuven.be

Dr Katarzyna Warmińska is a Polish anthropologist working on ethnic and identity issues. Her main interests focus on problems of ethnic identity, politics of identity, minority - majority relations and anthropological practice. She conducted fieldwork among Polish Tartars and Kashubians and published the research results in over forty peer-reviewed articles and in her book Polish Tartars. Religious and ethnic identity. She is an associate professor at the Department of Sociology at the Cracow University of Economics.

Address: Cracow University of Economics, Department of Sociology, ul. Rakowicka 27,31-510 Cracow, Poland; kwarminska@o2.pl 